Andrews University

Digital Commons @ Andrews University

1992

\title{
Theological Education in Context: A Pilot Extension Program for the Seventh-day Adventist Church in Rwanda
}

Robert G. Peck

Follow this and additional works at: https://digitalcommons.andrews.edu/dmin

Part of the Practical Theology Commons

\section{Recommended Citation}

Peck, Robert G., "Theological Education in Context: A Pilot Extension Program for the Seventh-day Adventist Church in Rwanda" (1992). Professional Dissertations DMin. 643.

https://dx.doi.org/10.32597/dmin/643

https://digitalcommons.andrews.edu/dmin/643

This Project Report is brought to you for free and open access by the Graduate Research at Digital Commons @ Andrews University. It has been accepted for inclusion in Professional Dissertations DMin by an authorized administrator of Digital Commons @ Andrews University. For more information, please contact repository@andrews.edu. 
ABSTRACT

THEOLOGICAL EDUCATION IN CONTEXT

A PILOT EXTENSION PROGRAM FOR

THE SEVENTH-DAY ADVENTIST

CHURCH IN RWANDA

by

Robert G. Peck

Adviser: Gottfried Oosterwal 


\title{
ABSTRACT OF GRADUATE STUDENT RESEARCH \\ Project Report
}

\author{
Andrews University
}

Theological Seminary

\section{Title: THEOLOGICAL EDUCATION IN CONTEXT: A PILOT EXTENSION PROGRAM FOR THE SEVENTH-DAY ADVENTIST CHURCH IN RWANDA}

Name of researcher: Robert G. Peck

Name and degree of faculty adviser: Gottfried oosterwal, Ph.D. Date completed: July 1992

\section{Problem}

One of the most important concerns that presents itself to the Adventist Church in Rwanda is how to adequately cope with the rapid growth of new members. There are too few pastors equipped to care for the growing membership.

It was the purpose of the present pilot project to design a strategy that would provide theological education and training for pastors currently employed and training for those mature church leaders who are motivated to improve their leadership abilities and skills. 
Method

Theological Education by Extension (TEE) was the proposed solution to the problem. A two-tier approach was suggested. The first-tier certificate level would be viewed as professional upgrading/continuing education training. It would accommodate all those needing and desiring training but not aspiring to attain the two-year intermediate-level diploma.

The second-tier diploma level would be directed specifically toward the attainment of a two-year intermediate-level diploma. This level would accommodate pastors lacking the ministerial diploma and those mature leaders who are the actual leaders of the rural churches, who need and desire theological training.

\section{Results}

Pastors and the newly trained lay leaders would be well equipped to care for their churches within the larger regional districts. As TEE graduates would function in their local churches, there would be a lessening of national church leadership deficiencies and a corresponding increase in competence. TEE graduates would be training the other members and imparting to them the knowledge they have gained. Both the TEE graduates and the members would be stimulated to higher learning levels. In addition, spiritual growth would be accelerated through increased participation of the newly trained members. 


\section{Conclusions}

The TEE program would integrate national leaders into teaching and administrative positions from the outset of the project. Dependence upon expatriate staff would reduce with each B.A.-level graduating class from AUCA. Extension graduates would be evaluated against their residence counterparts in secondary school. Regular monitoring of the program would insure that the proper academic standards would be maintained. The proposed strategy would give an overall framework and direction for meeting the present and future educational needs of church leaders within the Rwanda Union Mission. 


\author{
Andrews University \\ Seventh-day Adventist Theological Seminary
}
THEOLOGICAL EDUCATION IN CONTEXT
A PILOT EXTENSION PROGRAM FOR THE SEVENTH-DAY ADVENTIST
CHURCH IN RWANDA

\author{
A Project Report \\ Presented in Partial Fulfillment \\ of the Requirements for the Degree \\ Doctor of Ministry
}

by

Robert G. Peck

July 1992 

THEOLOGICAL EDUCATION IN CONTEXT

A PILOT EXTENSION PROGRAM FOR

THE SEVENTH-DAY ADVENTIST

CHURCH IN RWANDA

A project report

presented in partial fulfillment

of the requirements for the degree

Doctor of Ministry

by

Robert G. Peck

APPROVAL BY THE COMMITTEE:

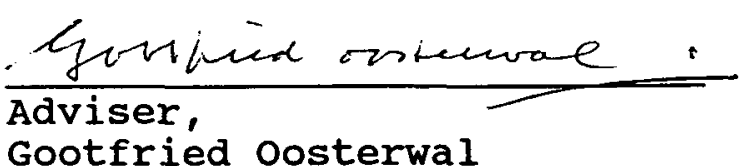

Gootfried oosterwal

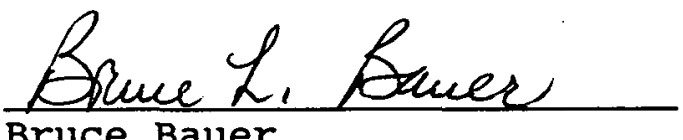

Bruce Bauer

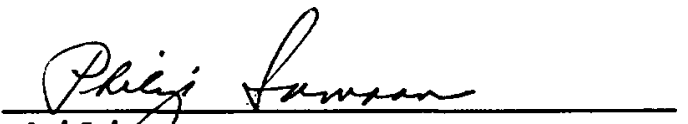

Philip/samaan

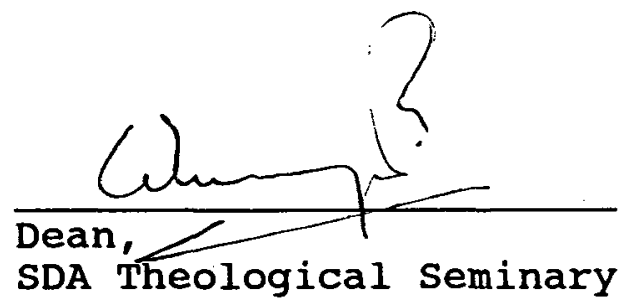

$\frac{\operatorname{July} 3,1992}{\text { Date approved }}$ 
TABLE OF CONTENTS

LIST OF FIGURES . . . . . . . . . . . . . . . . vii Chapter

I. INTRODUCTION . . . . . . . . . . . . 1

statement of the Project . . . . . . . 1

Limitation . . . . . . . . . . . 2

Description of the Problem . . . . . . 3

Contributing Factors ....... . 5

Resident Program Not Sufficient . . . 6

Rigid Entrance Requirements . . . . . 7

Lack of Finances For Ministerial

Training . . . . . . . . . 8

Mission Strategy Concepts . . . . . . 10

Proposed Solution ........... 12

Extension Education . . . . . . . . 15

Experiments with TEE in Africa . . . 15

Objections Encountered in

Connection with TEE . . . . . . 22

Application of TEE in Rwanda . . . . 27

Why TEE Is Needed . . . . . . . . . 28

What TEE Is Expected to Accomplish . 30

Expectations from the Project . . . . 31

II. THE ADVENTIST CHURCH IN RWANDA . . . . . . 32

Rwanda--Its Geography and culture . . . 32

Ethnic History . . . . . . . . . . . . 34

Colonial Heritage . . . . . . . . . 37

The German Period..... . . . . 37

The Belgian Period . . . . . . . . 38

Independence . . . . . . . . . . . 39

Present Situation . . . . . . . . . . 41

Economic Dependence within the Country . 43

Subsistence Economy .. . . . . . . 43

Crisis of Financial Dependency . . . 48

Christian Missions in Rwanda . . . . . . 49

Early Missions . . . . . . . . . . 49

Church Missionary Society . . . . . 51

East African Revival Fellowship . 52

Seventh-day Adventist Missions . . . 54

Early History . . . . . . . 55 
The Fire of Early Evangelism . . . 57

Evangelism Explosion ..... . 60

Evangelistic Fervor Dampened . . 63

Influence of Traditional

Society and Religion . . . . 64

Dependency of the Church . . . . . . 66

Urbanization . . . . . . . . . . . . 68

Secularization . . . . . . . . 69

Ministerial Training . . . . . . . 71

Statistical Projections . . . . . . 72

Adventist Education and Training . . 75

Adventist Training of the Laity . . . 78

III. ADVENTIST MINISTRY MODELS . . . . . . . 82

Biblical Models for Adventist Ministry . 82

old Testament Education and Training . . 82

Relationship of Education to

Redemption .......... . 83

The School of the Exodus . . . . . . 84

The Schools of the Prophets . . . . . 84

Location of the Schools... . . . 85

The Curriculum of Study . . . . . . . 86

New Testament Education and Training . . 87

The Education of Jesus . . . . . . 87

The Master's Plan . . . . . . . . . 88

Make Disciples . . . . . . . . . 89

New Testament witnessing . . . . 90

Method of Working . . . . . . . 91

World Church Education and Training . . 92

Adventist Training of the Ministry . 94

Practical Implementations in Rwanda . 97

Limitations of the current

Situation . . . . . . . . 98

The Need for a solution ...... . 100

Towards an Indigenous Model of

Ministry . . . . . . . . . . 103

Indigenization ........ . . . 104

Contextualization . . . . . . . . 106

A More Suitable Alternative . . . . . 110

Philosophy of Approach . . . . . . . 111

Curriculum Planning .......... . 114

Staffing Considerations . . . . . . 115

Location Rationale . . . . . . . . . 115

Method of Learning . . . . . . . . 117

Implementation of TEE . . . . . . . 117

IV. HISTORY OF TEE . . . . . . . . . . . . . 119

Origin in Central America . . . . . 119

Developments in TEE . . . . . . . . . 121

TEE in India . . . . . . . . . . . . 122

Mennonite Initiative . . . . . 123 
Honduras Dimension . . . . . . . 123

TEE in North Sumatra . . . . . . . 124

Extension in the USA . . . . . . . . 125

Philosophy of TEE . . . . . . . . . . 126

Experience in Australia . . . . . . 127

Experience in India . . . . . . . . 129

Experience in Spain... . . . . . 130

Models in Africa . . . . . . . . . . 131

African Independent Churches . . . 133

TEE in Tanzania . . . . . . . . . 134

TEE in Botswana . . . . . . . . . 135

Lessons Learned from TEE Models
and Experiences. . . . . . . 137

V. TEE AND ADVENTIST MINISTERIAL EDUCATION

IN RWANDA . . . . . . . . . . . • • . 141

The Need . . . . . . . . . . . . . . 141

The Philosophy . . . . . . . . . . . 141

Practical suggestions for

Implementation . . . . . . . . . . 142

Appropriate Sites and Structures . . 145

Staffing Considerations . . . . . . 147

Culturally Attuned Methods of

Teaching . . . . . . . . . 149

Programmed Learning Materials . . . 150

Weekly Center Meetings . . . . . . 152

Monthly Center Meetings . . . . . . 154

Program Curricula . . . . . . . . 154

First-tier Curricula . . . . . . 156

Second-tier Curricula . . . . . 157

Financial Considerations . . . . . 159

Extension Center Financial

operation . . . . . . . 160

Avoiding Potential Problems . . . 161

Candidate Selection . . . . . . . 162

Monitoring of Candidate's Work . . . 165

Advantages . . . . . . . . . . 166

Effectiveness for Minstry . . . . . 167

Obstacles to Implementation and How

to Overcome Them . . . . . . . . 168

Apprehension over Remuneration . . . 169

Fears of Lay Ordination . . . . . 171

Fears About Women in Ministry . . . 172

Challenge to the Traditional

Fears of a More Educated Laity . . 173

Expected Outcome . . . . . . . . . 174

VI. CONCLUSION. . . . . . . . . . . . 175

Summary of Issues . . . . . . . . . 175

Crisis Situation . . . . . . . . 175

Rapid Numerical Growth . . . . . 176 
Lack of Well-Trained Leaders . . . 176

Educational Elitism . . . . . . . 177

Traditional Methods Not Sufficient . 178

Proposed Solution . . . . . . . . 178

Expected Results . . . . . . . . . . 179

Recommendations . . . . . . . . . 182

Concluding statement . . . . . . . . 182

APPENDICES. . . . . . . . . . . . . . . . 184

A. Rate of Growth Statistics . . . . . . 185

B. Statistical Comparisons: Number of

Member Per Pastoral Worker . . . . . 187

c. Debt Analysis Figures . . . . . . . 189

D. Statistical Projections . . . . . . . 193

E. Maps. . . . . . . . . . . . . 195

F. Economic and Social statistical Comparisons English Tables are for 1988

French Tables are for 1992 . . . . . 199

G. Tables................ 220

H. TEE Translator contract . . . . . . . . 224

I. Economic Indicators . . . . . . . . . 228

J. Sample Training Program Formats . . . . . 235

K. Salary Categories: AID Wage Scale
and Continuing Education...... . 242

L. Programmed Learning Lesson Samples . . . . 247

BIBLIOGRAPHY. . . . . . . . . . . . 258

VITA. . . . . . . . . . . . . . 267 


\section{LIST OF FIGURES}

1. Extension Center Site Locations . . . . . 143

2. Academic Divisions into Two Levels . . . . 144 
CHAPTER I

INTRODUCTION

\section{Statement of the Project}

This paper deals with a practical issue, the development and rationale of a Theological Education by Extension ${ }^{1}$ program to train pastors and laymen in the Rwanda Union Mission of Seventh-day Adventists (RUM).2 Training of the ministry in a cross cultural context began to captivate my interest in the beginning of my missionary life. During seven years as president of the RUM commencing in 1984, I was regularly challenged with the problem of a lack of well-trained church workers in Rwanda.

${ }^{1}$ Hereafter TEE.

${ }^{2}$ Hereafter RUM. The RUM is an administrative unit of the Seventh-day Adventist Church in Rwanda composed of three fields: the East Rwanda Field comprised of the prefectures of Byumba, Kibungo, and Kigali; the North Rwanda Field comprised of the prefectures of Gisenyi, Kibuye, and Ruhengeri; and the South Rwanda Field. comprised of the prefectures of Butare, Cyangugu, Gikongoro, and Gitarama. Adventist organizational structure has four levels: (1) the local church level, (2) the field or conference level, (3) the union level, (4) the division level, which is the extension of the General Conference in the ten divisions of the world. 


\section{Description of the Problem}

The Adventist Church in Rwanda is confronted with a twofold crisis: (1) numbers and (2) economy. The church has grown extraordinarily fast. ${ }^{1}$ This rapid growth has put the church in a situation where there are too few pastors equipped to tend it. Projections show ever larger numbers of members per pastor. ${ }^{2}$ There are many sheep and too few shepherds. This condition has especially been a problem in the RUM. In addition, local economy of the church has not been sufficient to meet the financial needs created by the rapid growth in church membership. ${ }^{3}$

Not only are current educational facilities unable to produce the numbers of trained people actually needed by the church, but those in the churches who are currently engaged in ministry are unable to gain access to the available training for several reasons: finances, entrance equivalency, and existing institutions are already crowded. Needed basic instruction is not available to allow the practicing leaders to minister effectively.

The present institutions are unable to build and equip enough facilities to meet the growing needs of the

\footnotetext{
'See Appendix A, Rate of Growth figures.

${ }^{2}$ See Appendix B, Members Per Pastor ratios.

${ }^{3}$ See Appendix C, Debt Analysis figures.
} 
church in Rwanda. Another concern is the ability of present institutions to sustain their present operation needs. Operating budgets are not able to provide sufficient maintenance funds for even newly constructed buildings.

Adventist church members, in consequence of their belief in the imminent return of Jesus Christ, feel an urgency to aggressively evangelize in harmony with the Gospel Commission. The number of people joining the church in Rwanda is what is stretching the church to its limits to adequately care for its new adherents. The unprecedented growth is pressing the Church to consider alternative methods for training leaders.

More than 26,000 new adherents were added to the Seventh-day Adventist ${ }^{1}$ church during 1990 in Rwanda. While the official baptized membership was just over $220,000,2$ an estimated 400,000 to 600,000 other people professed the SDA tenets of faith and attended the more than 700 regular weekly church services. ${ }^{3}$ About 200 pastors shepherd the rapidly expanding congregations. ${ }^{4}$

\footnotetext{
${ }^{1}$ Hereafter SDA.

${ }^{2}$ Rwanda Union Mission, Secretary's Statistical Report-Quarterly, 4th quarter, 1990.

${ }^{3}$ Ibid.

${ }^{4}$ See Appendix D, Statistical Projections by year.
} 
Contributing Factors

The shortage of qualified leaders is exacerbated by the fact that many of those who are trained for the ministry obtain higher paying jobs in the public sector. Government and business opportunities are constantly drawing graduates away from the service of the church. Consequently, church administrators are hesitant to invest money in ministerial candidates who have not given full proof of their ministry. Unless candidates have successfully demonstrated their aptitude for ministry in a local field, it is unlikely they will receive financial assistance to pursue advanced theological studies. Those who have found sponsors on their own to support them through their university theology program may also find it difficult to enter the pastoral ministry because administrators have not approved them. Administrators are not eager to employ those who want the security of denominational employment but have no commitment to the ministry.

Ministerial training, formerly offered as a terminal intermediate level two-year program at Gitwe College, 1 was suspended in order to give full support to

"The term "college" is used in the French system to designate a secondary school. Gitwe was the first secondary school opened in the Republic of Rwanda by the Seventh-day Adventist church. It is located about ten miles north of Nyanza in the central part of the country. See map in appendix $E$. 
the new Universite Adventiste d'Afrique Centrale (AUCA) ${ }^{1}$ which offers an overall plan to upgrade the ministry to the B.A. level. This change in the ministerial training program has created a vacuum in that there is now no source of intermediate-trained leaders for service at the church grass roots level.

\section{Resident Program Not Sufficient}

The AUCA program is unlikely to fulfill the need for ministers. AUCA is a private post-secondary institution which was established to provide tertiary education for students of the French-speaking countries of Africa. The principal objective of the institution is to provide an educational program at the professional level that integrates theoretical and practical learning. The course offerings were chosen to satisfy the priority needs of the SDA church in the French-speaking countries of Africa. B.A.-level degrees are offered by AUCA in business, science, education, and theology. The school also offers a two-year degree in industrial technology. ${ }^{2}$

\footnotetext{
${ }^{1}$ Hereafter AUCA. AUCA is the acronym for the English form of the name Adventist University of Central Africa. This institution is the first French-speaking Adventist school of higher learning on the continent of Africa to offer the baccalaureate degree. It opened for classes in 1984 and conducted its fourth graduation in June of 1991. See map in appendix E.

${ }^{2}$ Universite Adventiste d'Afrique Centrale bulletin, Annuaire De L'Annee Academique. Mudende, Rwanda: Universite Adventiste, 1988-1989, 5.
} 
The church needs B.A. level graduates. However, few graduates in theology will be of a benefit to the church according to projected estimates, 1 for not more than ten graduates per year over the present decade are expected. In addition, many university graduates are very selective about the positions they are willing to fill for the church. Some are willing to serve only in developed areas. Single graduates want the social life that urban centers offer. Some graduates refuse to consider any work assignment outside the capital city:

1. These graduates will not meet the needs of the rural churches and institutions, for they aspire to serve only the urban centers. As resident students, they have lived in houses with electricity, running water, inside plumbing, and telephone availability. To return to the primitive living conditions of the rural areas is considered demeaning and unfulfilling.

2. The fields cannot afford to employ large numbers of these graduates. Their starting salaries are two to three times higher than those of the older ordained pastors.

\section{Rigid Entrance Requirements}

Many of the workers currently engaged in ministry are unable to get access to the training they require

\footnotetext{
${ }^{1}$ See appendix D, statistical Projections by year.
} 
because they lack a secondary diploma. Presently, there is no entrance equivalency testing available at AUCA, or at any of the schools in Rwanda, and students must have a diploma from a recognized secondary school for entrance to the school of theology. Thus, academic prerequisites make it impossible for those of limited educational background to progress scholastically. Concepts of family and prestige also prevent these workers from returning to secondary school to complete requirements for a diploma. Most would also find it demeaning to study in a classroom alongside their own children.

\section{Lack of Finances for}

Ministerial Training

The church in Rwanda is interested in supporting AUCA and five percent of the tithe is regularly sent by the local fields to subsidize the operation of the school. Because very few students are enrolled in the Theology program, very little graduate level help is being realized in the local churches. The churches find it difficult, therefore, to justify the financial commitment being made to AUCA.

The average pastoral worker finds it practically impossible to finance a program at AUCA, even if he is academically qualified to enter the program. Pastoral families are large and there is a low participation level of the church members in the faithful giving of tithes 
and offerings. Concepts of faithful financial support are still in their infancy in Rwanda. Only about 15 percent of the church members in the Rwanda Union returned a faithful tithe in 1989. Tithe from the local fields has simply been insufficient to adequately support the local pastors.

The education of their own children can easily take more than pastors receive in salary. Consequently, pastors can think of further educational upgrading opportunities for themselves only if these are provided for them at very low personal cost.

The limited financial support church members give to the church means that its resources are too thin to support large numbers of highly educated and well-paid pastoral-ministerial personnel.

Parents have one primary concern--the education of their children. Eight self-supporting secondary church schools are presently being operated by Adventist parents. Though these are worthy projects, tithe that could be used to increase pastor's salaries is diverted to the operation of these schools. As a result, a great disparity exists today between the salaries of pastors and teachers. Pastors tolerate the disparity because many of their children are being educated in the classrooms of the higher paid teachers. If the teachers salaries do not approximate those of the public school 
teachers, then the teachers often accept teaching openings in the public schools. Members will sacrifice to provide the teacher salaries, but they do not have the same burden for the salaries of pastors. Rather than have their children taught by non-SDA teachers, the pastors accept the disparity in wages.

Due to the poverty of the country, the lack of income of the individual members, the existing financial constraints of the local churches, the institutionalism of the church which focuses financial resources on the traditional approaches to education, and the dependency upon western modes of education which require large capital investments in buildings and personnel, many church leaders have no access to formal training programs.

\section{Mission Strategy Concepts}

It is becoming increasingly difficult for the overseas church to subsidize the salaries of African workers. The strategy of mission planning of the General Conference of Seventh-day Adventists demands that more funds be allocated to the evangelization of people where the church has no established work. This means that appropriations will be reduced from overseas to the Appendix F.

${ }^{1}$ See table 6, Economic Indicators, on line 18 in 
church in countries with established work. ${ }^{1}$ when expatriate salaries, provided by the General Conference, ${ }^{2}$ are removed from countries with established work, they will have to be replaced with locally funded salaries. The RUM has lost more than a dozen expatriate salaries over the past few years. In 1988 six were removed. Another four were dropped in 1990 when currency fluctuations in the rates of exchange in the countries comprising the Africa-Indian Ocean Division ${ }^{3}$ territory made it necessary to reduce AID expatriate salaries by thirty-nine. Again in 1991 budget adjustments in the AID reduced the number of missionary salaries for Rwanda requiring more worker salaries to be covered by locally raised funds.

The strategy of shifting financial appropriations to unentered areas may be positive, but before current expatriate salaries are withdrawn from established churches to send missionaries to the unreached, efforts must be made to ensure that local churches are standing firmly on their own financial feet. Unfortunately, these

\footnotetext{
${ }^{1}$ Carlos Medley, "New Strategy for Africa," Adventist Review, October $30,1986,13$.

${ }^{2} \mathrm{Highest}$ organizational level of the seventh-day Adventist Church.

${ }^{3}$ Hereafter AID. The AID covers thirty-three countries including all the French speaking countries of Africa and the Indian Ocean in addition to the Portuguese speaking Cape Verde Islands off the coast of West Africa.
} 
missionary salaries are not freed for new work within

Rwanda but are withdrawn and used elsewhere.

The crisis of dependency within the church, due in part to church polity, has cut the nerve of local

stewardship. Now that appropriations from parent church organizations are being reduced, the true economical status of the church must be considered more realistically. The operation of the formerly subsidized church, and the fulfillment of its mission, must be executed within the economic limitations of the society. In other words, training of future leaders and operational costs of the church in Rwanda must be guided by the economic capacity of the local membership.

\section{Proposed Solution}

TEE seems to offer a practical solution to the specific problems being experienced in Rwanda in consequence of rapid member growth and limited financial resources. The proposed TEE program may be qualified as follows:

First, it is theological. It can teach what God is about and what He does. It provides training in all the basic foundations of christian instruction. Prepared texts are used to cover a wide range of Biblical, theological, and practical subjects.

second, it is educational. Using sound teaching principles it solves the need for training those unable 
to attend a residence program. Through the use of Programmed Learning Texts self-education is accomplished. People learn at their own rate of speed and relate their studies daily to their local church work.

Third, it is taught by extension. Students learn at home. The classroom is brought to students who cannot regularly leave home and work to attend school. Selfteaching at home on an ongoing basis is the goal.1

Three essential components are needed for a successful TEE program: lesson materials, seminar meetings, and field experience. Dr. Ted Ward, formerly of Michigan State University, explains that "T.E.E. is like a fence. Its three parts are like the wires and the posts."2 The top wire represents the lesson materials. The posts represent the regular meetings that follow one after another. The bottom wire represents the field experience.

Lessons are done at home requiring students to have their own learning materials. Students write in answers or do other assignments as instructed in the texts. Regular meetings provide the framework for the fence. Teachers are basically facilitators at the meetings. These university-trained facilitators, already

${ }^{1}$ Fred Holland, Teaching Through T.E.E. (Nairobi, Kenya: Evangel Publishing House, 1975), 9.

${ }^{2}$ Ibid., 10. 
employed by the church, do not give new information but answer questions about what the students have studied in their texts. Students are then evaluated on their effectiveness at integrating what they have learned into their own lives and work.

The Theological Education by Extension program has been described as integrating three basic components: (1) personal independent systematic study by the student, (2) regular on-going participation of the student in the ministry of his own local church, (3) periodic seminars between the students and tutor for the purpose of integrating theory and experience. ${ }^{1}$ TEE is designed to extend an opportunity to those needing and desiring theological education but unable to receive such training on the university campus.

Efficiency in ministry is stressed above academic excellence. The cycle of studies administered at the strategic centers is planned to geographically accommodate the candidates. Time is arranged for weekly and monthly seminars that best accommodate the students. The seminar is designed to provide information, motivation, inspiration, fellowship, confirmation, clarification, encouragement, and testing.

\footnotetext{
'Jonathan Hogarth, Kiranga Gatimu, and David Barrett, Theological Education in Context (Nairobi, Kenya: Uzima Press, 1983), 29-30.
} 
Extension Education

It was my privilege during the seven years in Rwanda to be actively pursuing my Doctor of Ministry degree by extension. My own extension program allowed me to continue in full-time work with a focused curriculum around my needs as a practicing administrator. It provided me with an educational experience in a flexible time and location setting. At the same time it allowed me to apply what I studied immediately to my work experience. My ministry was being improved while I continued my regular work responsibilities uninterrupted. Conviction began to grow in my thinking that a similar program could provide similar benefits to our national workers in Rwanda. During my doctoral studies I became acquainted with TEE. A preliminary research of TEE led me to the discovery that many other church organizations, which have experienced similar problems to those encountered in Rwanda and described above, found an answer in the TEE program.

Experiments with TEE in Africa

TEE workshops were first started in 1969 in the country of Kenya. ${ }^{1}$ The problem in Africa was that there were no suitable home study books. To facilitate this

${ }^{1} \mathrm{~F}$. Ross Kinsler, The Extension Movement In Theological Education (Pasadena, CA: William Carey Library, 1981), 172 . 
program in Africa, the Evangel Publishing House in Nairobi published a series of forty programmed learning texts. These texts reflect intensive efforts to make simple self-study materials available to the people of Eastern Africa in English and Swahili.

Both churches and missions realized that "there were thousands of leaders of local worshipping groups who had inadequate, if any, training for their ministry involvement."l Existing programs were not training enough people or the right people. Church leaders on all levels lacked full training to perform their assigned responsibilities adequately. Yet, they were already in ministry. TEE was viewed as a way to help people currently involved in ministry.

An ecumenical extension program was started in South Africa in 1975. An independent board was set up two years later with representatives of "six sponsoring churches: African Independent, Anglican, Congregational, Lutheran, Methodist, and Roman Catholic."2 Courses are being offered on three academic levels for persons wanting further training to increase their personal effectiveness in ministry. Lay people, candidates for the

${ }^{1}$ F. Ross Kinsler, Ministry by the People (Geneva, Switzerland: WCC Publications, 1983), 106.

${ }^{2}$ Ibid., 174 . 
ordained ministry, and ordained clergy are all being trained.

A TEE program was started in Malawi in 1979 with headquarters in Blantyre. Seven church bodies worked in cooperation with Anglican, Churches of Christ, and Independent Baptist Convention groups represented on the governing board. The fourfold aim was:

To provide adequate and thorough Biblical training for lay persons in the churches of Malawi. To give Biblical training for lay ministers such as catechists and evangelists.

To assist in the theological training of candidates for the ordained ministry.

To provide an instrument for continuing education and upgrading of clergy. ${ }^{1}$

In preparation for the accomplishment of the above objectives, a training program was established to develop national and locally based tutors and course writers. The 1980 enrollment in the TEE courses in Malawi was 121, twenty-two of which were in the post-secondary course. ${ }^{2}$

The Anglican Church, the Churches of Christ, and the United Church of Zambia cooperated in the opening of a TEE program in Zambia in 1980. The project follows the basic format of TEE being used throughout Africa. It works to make teachers out of the TEE students through

\footnotetext{
${ }^{1}$ Hogarth, and others, 91, 92.

${ }^{2}$ Ibid. , 93.
} 
in-service training. In-service students are sent out to find suitable students in their congregations whom they can teach. Using their own programmed texts and notes from their weekly seminars, the in-service students share the newly learned leadership principles and skills.'

A TEE program has been functioning out of the Baptist School of Theology located in Lome, Togo. The resident school itself is the result of the cooperative effort of the Baptist Mission in six West African countries: Benin, Ivory Coast, Niger, Senegal, Togo, and Burkina Faso. These Baptist groups have worked together to satisfy their needs creatively. Courses are taught on different levels. In Table 1 (see Appendix G), one can see how TEE and the residence program work together. ${ }^{2}$ Work on the first two levels is done under the TEE format. Students have the advantage of immediate application of what they have learned. Levels three and four can be done completely through $T E E$, or a combined residence and TEE program can be chosen. Pastors and laymen can study at all levels. Requirements for the laymen to obtain a certificate are less rigorous than those for pastors but the materials are the same. ${ }^{3}$ The academic year for the residence program is

${ }^{1}$ Ibid., 98.

${ }^{2}$ See Appendix G, Curriculum Combinations.

${ }^{3}$ Hogarth and others, 107. 
divided into twelve-week quarters. Two courses may be taken by a student in any one quarter. A student can elect to do all their study by TEE or a combination of TEE with periods of residential study.

In a personal interview, Pastor Tim Matchett who coordinates the Baptist School of Theology in Lome, reported that at first there was a problem with the credibility of the TEE program because it was by correspondence. However, it has worked very successfully in conjunction with the residence program. Many workers are currently benefitting from TEE who could not enter the residence program.

About ten years ago, Conservative Baptist church leaders held a meeting in Nairobi, Kenya, with representatives from seven African nations. The recurring theme was the urgent need for developing qualified church leaders. The Rwanda delegates indicated a need to prepare 400 leaders for churches over the next ten years. At that time they were graduating a maximum of fifteen candidates for the ministry per year from in-residence programs. ${ }^{1}$ Today the Baptists have the only TEE program in the country of Rwanda. Permission has been granted to them by the Evangel Publishing House in Nairobi to translate their Programmed Learning texts into the

${ }^{1}$ Lois McKinney, "Why Renewal Is Needed in Theological Education," Evangelical Missions Quarterly $(1982): 86$. 
national language, Kinyarwanda.

The aim of the Programmed Learning texts is to meet the training needs for local church leaders at the grassroots level. The texts are basically interdenominational. A small printing center has been established in Butare and the texts are printed on a small scale. According to the agreement ${ }^{1}$ made with the Evangel

Publishing House translation must be direct without any modification or additional material.

The Baptists had their first TEE graduation exercise in January of 1990. By December of 1991 a total of 125 had finished the four-year series. The number in training is currently $360 .^{2}$ success of the program has encouraged the translation of more texts. Graduates are reported to be more productive and more involved in church work than their untrained counterparts who pastor rural churches but have not received the TEE training.

A number of problems are being experienced with the program:

1. Teacher preparation is weak in some cases.

2. Students are left to study on their own without adequate help. They lack motivation, discipline to

${ }^{1}$ See Appendix $H$ for a Copy of the Agreement.

${ }^{2}$ R. G. Pierson, Rector of AUCA, to author, December 13,1991 . 
budget a set time for study, and appropriate space for study.

3. Many church leaders tend to think of TEE as a glorified sunday school program. They don't take it seriously until the good graduates start proving themselves. ${ }^{1}$

The Free Methodist Church in South Africa began experimenting with TEE seriously in the early 70 s. Declining enrollment at their residence training program in Eastern Transvaal precipitated an initial interest in TEE. TEE began in the Transvaal, the northernmost province, and then spread to Rhodesia and Natal/Cape. ${ }^{2}$ The administration was confronted with the prospects of closing Baker Memorial Bible School if enrollment did not increase. In January, 1972, there were three students in the residence training program. Within a few weeks two of the three students left. TEE turned the low enrollment around. It became an extension of the residence program. "TEE was considered an extension of existing schools and not a separate approach or a competitor." ${ }^{3}$ The first year there were eighty

\section{${ }^{1}$ Ibid.}

${ }^{2}$ Donald William Crider, "Development and Rationale of Theological Education by Extension of the Free Methodist Church in South Africa" (M.A. thesis, Fuller Theological seminary, 1980), 23.

${ }^{3}$ Kinsler, 108 . 
students in the Transvaal and 132 in the Natal/Cape. ${ }^{1}$

Another problem made the TEE program attractive to the mission leaders. Many of the candidates in the residence program who were chosen and sponsored by missionaries proved unsuitable for the local churches. They received excellent training but did not have an aptitude for the ministry. In other words, candidate selection was weak.

When the mission leaders turned to TEE they began training men who were already functioning in various capacities in the local church. ${ }^{2}$ There was a natural screening process in following this procedure. students were no longer removed from their actual employment and church ministry for several years in order to receive training. Instead, the candidates could remain in their own homes and receive training because the school was brought to them.

\section{Objections Encountered in}

connection with TEE

Lack of a cloistered and a spiritual atmosphere for students is one objection that has been encountered with TEE. Students in extension programs are not brought together to live together. They miss an atmosphere that

$$
\begin{aligned}
& { }^{1} \text { Crider, } 28 . \\
& { }^{2} \text { Ibid., } 31 .
\end{aligned}
$$


is helpful to spiritual growth and development. ${ }^{1}$

Extension has ways of doing this that differ from the residence programs, but which prove to be effective. A weekly seminar at the TEE center may be devoted to allowing and providing for spiritual exercises. ${ }^{2}$ special studies and devotional messages may be conducted during the weekly meetings. Personal counseling may also be made available. Spiritual fellowship and growth may be an essential part of the regular center meetings.

Neither the residence schools nor TEE can guarantee the spiritual growth of a student. Yet, it has been noticed that spiritual growth that is maintained day by day alone, as in the case of TEE students, often proves to be a long lasting and valuable growth pattern. TEE students often come from churches where they are already fuctioning as spiritual leaders. They are usually the more mature leaders who are less likely to be led and formed by their atmosphere. What they learn is applied directly to their situation. As they share what they learn, it is live, applicable truth. ${ }^{3}$

Another objection encountered in connection with

\footnotetext{
${ }^{1}$ Ronald P. Mackinnon, "A Program of Theological Education by Extension and Lay Preacher's Institutes for the Christian and Missionary Alliance Church (and Mission) of the Philippines" (M.A. thesis, Fuller Theological Seminary, 1975), 53.

$$
\begin{array}{ll}
{ }^{2} \text { Ibid., } & 54 . \\
{ }^{3} \text { Ibid., } & 55 .
\end{array}
$$
}


TEE programs is the length of time that it takes to graduate. When people spend their time making a living they obviously have less time to study. When studying by extension most students will only take one to three courses at a time. At that rate it could take ten to fifteen years to graduate from a TEE program.

While some very motivated students have finished their studies by extension in the same period of time that the residence students have finished, these are the exception. Most students will study seven, eight, ten, twelve, or fifteen years. "Yet the question must be, is it too long a time?" 1 since the student is not away from his or her family and does not have to be supported by someone else, there is no pressure to rush the completion of the program. The longer study period also tends to establish a life long habit of study.

TEE is basically aimed at those who would not otherwise get theological training. Though they are required to study for long years, eventually they will be able to graduate. During their study they will become more capable Christian leaders year by year. Their training will not unfit them to serve their cultural setting. Instead, they will be helped to achieve their goals of learning. At the same time they will use the knowledge and skills they gain in daily ministry.

\footnotetext{
${ }^{1}$ Ibid. , 56 .
} 
Another objection is that TEE will adversely affect the enrollment and viability of current residence schools. The fear is that a residence school may be closed in favor of a TEE program. If not closed, enrollment may greatly suffer. However, experience has shown that as an extension student studies at home he is sometimes led to enroll as a full-time student.' Rather than weakening the residence program, TEE has a tendency to increase interest and enrollment in the residence school. Some students will choose to study by extension because of their particular situation. These, however, are usually the older more responsible students who would be faced with many problems were they to choose the residence school.

Another objection is that instruction by extension is inferior and the end-product is not held in esteem by the academic world. This objection is primarily one that is promoted by those who feel that TEE programs constitute a threat to the residence school.

It is important to start the TEE program high enough to avoid undue prejudice, and at the same time low enough to do the job. ${ }^{2}$ Providing more than one track increases participation and also the level of

IIbid., 57.

${ }^{2}$ Ralph D. Winter, ed., An Extension Seminary Manual: Theological Education by Extension (Pasadena, CA: William Carey Library, 1969), 441-442. 
satisfaction of those in the program. Residence degree holders may have a tendency to give a condescending look toward those in the extension program. This can, however, be greatly reduced by the extension and the residence programs working closely together.

Instructors in the residence schools can give positive reinforcement to the TEE program through their residence classroom training and their periodic participation in TEE training. The same is true of graduates from the residence programs. They must understand that the majority of the world today is not on the post-graduate level.

since different kinds of students are enrolled in TEE (from the lower level of education to the higher level), a classification of the students is necessary. In this way the training of leaders for every need of the church on every level can readily be supplied. TEE does not duplicate what the residence program is doing but supplies a lack not currently being met at the residence school.

Having well-trained facilitators, many of them graduates of a residence program, helps to raise the perception of TEE. "All teachers must have special extension teaching training."1 TEE trainers are facilitators

${ }^{1}$ Rehmat Masih, "Theological Education in Pakistan: A Case study of the Gujranwala Theological seminary" (M.A. thesis, Fuller Theological Seminary, 1974), 128. 
and do not teach as in the normal classroom setting. Therefore, specialized orientation is essential.

\section{Application of TEE in Rwanda}

A pastoral ministry at different levels is required in Rwanda because of the cultural and educational distance between rural and urban groups within Rwandan society. A pilot project is proposed with a twotier curriculum to train leaders for smaller rural districts and church responsibilities. The first-tier would accommodate those candidates with less than primary school qualifications. The second tier would accommodate those candidates with secondary school capacity.

Departmental directors at the field and union levels would serve as the primary tutors. Graduates from AUCA would be employed as intern tutors and supervisors of the TEE graduates. University graduates would be responsible for the greatly expanded district responsibilities and the large urban centers.

TEE candidates benefit by the instruction they receive while they continue working. These are the leaders who currently serve the rural churches and who will continue to do so at the conclusion of their training.

Classes would meet weekly. The sessions would be from two to four hours each. In addition to the weekly sessions there would be a monthly seminar. The monthly 
meeting would bring all extension students together in one location. Special features and speakers would be planned for the monthly meetings.

\section{Why TEE Is Needed}

Residence training programs require elaborate facilities and extensive expatriate staff. A TEE program would be conducted by well-trained national staff members currently employed on a national salary. The use of national staff and salaries results in a significant difference in costs and a smaller staff.

A fairly high attrition from the pastoral ministry has been experienced with university graduates. Attrition rate of lay leaders trained in TEE programs has proved to be low because careful screening, testing, and selection has already taken place at the local church. Experience has shown that church members recommend those candidates for training who are actually their trusted leaders.

Costly tuition and boarding charges can be avoided. Centers can be located in strategic parts of the country making boarding unnecessary. Tuition costs to the student can be minimal. Intensives can be subsidized by Union offerings taken quarterly to assist the training program, therefore keeping charges to the TEE candidates minimal.

The educational level of TEE graduates would not 
rise drastically above and beyond their cultural setting. The students would work at their own pace for their own goals rather than for the goals of an institution. They would be more interested in learning and applying what they learn than in receiving a degree or diploma. Those who take only one or two subjects would not be counted as failures. The whole process of achieving personal goals through learning would be more relaxed than in a residence program.

Since the local church economy cannot support large numbers of university graduates in the pastoral ministry, TEE graduates would provide savings at the grass-roots level through a self-supporting ministry.

In the history of Christian missions, the name of Henry Venn stands out as being one of the primary architects of the concept of self reliance. "The key to all Venn's policy in regard to the native church was his concern that always it should be potentially a church of the country, a church that could become self-governing, self-supporting, and self-extending."I Venn was General Secretary of the Church Missionary Society for thirty years $(1841-1871) .^{2}$ During this time he encouraged the

${ }^{1}$ Max Warren, To Apply the Gospel (Grand Rapids, MI: William B. Eerdmans Publishing Company, 1971), 26.

${ }^{2}$ Albert M. Long, "Christianity in Rwanda with Special Emphasis on the Seventh-day Adventist Church" (M.A. thesis, Andrews University, 1973), 58 . 
setting up of indigenous churches under the leadership of indigenous workers. The plans he advocated influenced the decisions of the World Missionary Conference of 1910 in Edinburgh to define the goal of Evangelical Missions "as the establishment of self-supporting, self-governing, and self-propagating churches."1

TEE can be the catalyst to move the members of the churches in Rwanda toward self-supporting, selfgoverning, and self-propagating churches. No serious efforts are being made in this direction at the present. Training has not reached the local leaders who can effect a change. TEE can reach those leaders who regularly minister to and have the confidence of the members. Once the leaders themselves are trained, the desired positive changes among the members can be expected. Having welltrained self-supporting leaders can be a reality with the proposed TEE program.

\section{What TEE Is Expected}

to Accomplish

It is anticipated that TEE graduates would be well qualified to serve their congregations. Their training would be expected to result in a caring, sharing, discipling, equipping ministry. Their training would provide not only essential knowledge for effective

\footnotetext{
${ }^{1}$ Carl J. Hellberg, Missions on a Colonial Frontier (Sweden: Berlingska Boktryckeriet Lund, 1965), 129.
} 
leadership, but it also would increase their standing and credibility in their local communities.

Graduates would have a much clearer understanding of the uncertainty of economic and political stability in the world today. The TEE training they receive would prepare them to cope with financial stringency and to help safeguard the church in times of peril. Should crises occur, these leaders would be able to nurture the continued growth of the church. Many of them would serve in a self-supporting ministry role. In fact, they would establish a new pattern of ministry to fill a neglected slot. They would be prepared under any circumstances to use their acquired evangelistic skills to foster the rapid growth and development of the church.

\section{Expectations from the Project}

The immediate goal is a viable design for a pilot TEE program in the Rwanda Union Mission. It is hoped that the study will provide a useful educational tool to help key church leaders conceptualize and implement the pilot project. Should the pilot TEE project prove successful in Rwanda, it may prove useful also in other areas with similar needs. 
CHAPTER II

THE ADVENTIST CHURCH IN RWANDA

\section{Rwanda--Its Geography and Culture}

Located two degrees south of the equator in eastcentral Africa, Rwanda is a landlocked country covering 10,186 square miles. Inland from the Indian Ocean some 700 miles to the west, it is bordered by Uganda to the north, Burundi to the south, Zaire to the west, and Tanzania to the east." Known as "the Switzerland of Africa" and "the Land of Eternal Spring," Rwanda is in the heart of the central African plateau surrounded by lakes Kivu, Tanganyika, and Victoria. ${ }^{2}$

Much of the countryside is covered by grasslands and small farms extending over rolling hills, but there are also areas of swamps and rugged mountains, including volcanic peaks north of Lake Kivu, in the northwest border area. The divide between two of Africa's great watersheds, the Congo and Nile basins, extends from north to south through western Rwanda at an average elevation of almost 9,000 feet. ${ }^{3}$

\footnotetext{
${ }^{1}$ Richard F. Nyrop and others, Area Handbook for Rwanda (Washington, DC: U.S. Government Printing office, 1985), 25.

${ }^{2}$ John W. Simmonds, Jr., "How the Banyarwanda Understand Man," Practical Anthropology 10 (1963): 17, 18.

${ }^{3}$ Nyrop and others, 25.
} 
About two centuries ago approximately 60 percent of the land was estimated to be forest. ${ }^{1}$ Today, the surviving forests cover less than 3 percent of the nation's land." "The pattern of life is overwhelmingly rural, 95 percent of the population being engaged in agriculture." ${ }^{3}$ Subsistence farming is extremely precarious because of the smallness of the farms and the density of the population. In 1975 the population density was 413 persons per square mile. ${ }^{4}$ Today it is approximately 777 persons per square mile. ${ }^{5}$ Each passing year increases the demand on ever smaller parcels of land. Even in a good harvest year, food needs are barely met because of the large families. ${ }^{6}$

The traditional ways of life remain the dominant pattern in the rural areas. Each family occupies a selfcontained homestead on its

${ }^{1}$ C. P. Groves, The Planting of Christianity in Africa, 4 vols. (London, England: Letterworth Press, $1964), 1: 11$.

${ }^{2}$ Nyrop and others, 35.

${ }^{3}$ Ibid. , 39.

${ }^{4}$ David B. Barrett, "Rwanda," World Christian Encyclopedia, (1982), 588 . 1992.

${ }^{5}$ P. C. Globe, P. C. Globe, Inc., Tempe, Arizona,

'James P. Grant, La Situation Des Enfants Dans Le Monde 1992 (Geneva, Switzerland: Tex SA, 1991), 72, 74, 80. See tables 1,2 , and 5 in Appendix F. 
own plot of land. - . Surrounding the enclosed compound is the family banana plantation, the produce of which is used in the making of beer, a drink important in social functions.

No navigable rivers or railways cross Rwanda. Domestic transport is therefore dependent on the road network. Regular bus services connect the larger centers once or twice a day. Most areas are frequently serviced by minibus/taxi operators, although not on a scheduled basis.

\section{Ethnic History}

The Rwandese population $(6,709,000)^{2}$ is divided into three ethnic groups. The Batutsi, a Hamito-Nilotic group today accounting for about 10 percent of the population, were originally semi-nomadic herdsmen who, along with their cows, entered Rwanda in about the twelfth century A.D. They found two other groups, older and less nomadic, already there, and became their ruling overlords: namely, the Bahutu (a Bantu group), who today account for about 88 percent of the population and who are mainly farmers and craftsmen, and the Batwa (a Pygmoid group), who make up about 1 percent of the present population. ${ }^{3}$

\footnotetext{
${ }^{1}$ Nyrop and others, 39. "Rwanda."

${ }^{2}$ Britannica Book of the Year, 1989 ed., s. v.

$$
{ }^{3} \text { Ibid., } 43 \text {. }
$$
}


Ruanda [former spelling] at the beginning of this century could be characterized as a caste society if by that is meant a collectivity composed of several hierarchical groups, each predominantly endogamous, with its own traditional occupations, and made up almost exclusively of individuals born of parents themselves belonging to the group. The two principal castes were the Hutu agriculturalists and the Tutsi leaders. The latter enjoyed a dominant position that permitted them to exploit the farmers in the sense that they obtained a proportionately greater quantity of consumption goods without furnishing the counterpart in labor. ${ }^{1}$

The principle of inequality in Rwanda was such that the different castes are essentially considered "unequal in inborn endowment, physical as well as psychological and have consequently fundamentally different rights." 2

According to the above premise it was caste affiliation that was primarily responsible for inequality. ${ }^{3}$ The status of a poor Tutsi was considered to be above that of a wealthy Hutu. One was upper caste; the other was lower caste.

Regional concerns were also important. In the north, clan and lineage were paramount. Patron and

${ }^{1} \mathrm{~J}$. J. Maquet, "The Problem of Tutsi Domination," in cultures and societies of Africa, ed. Simon ottenberg and Phoebe Ottenberg (New York: Random House, 1960), 312, 313 .

${ }^{2} \mathrm{~J}$. J. Maguet, The Premise of Inequality in Ruanda (London, England: Oxford University Press, 1961), 165.

$$
{ }^{3} \text { Ibid., } 164
$$


client social relationships prevailed in the south. ${ }^{1}$

Positioning within the social structure for the Hutu and Tutsi was reversed by the social and political events between 1959 and 1962, but many of the essential features of their cultures have been retained.

It is difficult to distinguish which cultural features were principally Tutsi from those which were originally Hutu. Clan membership probably began with the Tutsi, and the focus on cattle, which became the basis of the society, evolved from the pastoral Tutsi tradition. On the other hand, the common language, Kinyarwanda, is the Bantu language of the Hutu. ${ }^{2}$

The third group, the Batwa, which is of Pygmy origin, lived off the land and by hunting. Gradually, they left the forests and mingled with the other two groups and most are now integrated into society. Their main activity is pottery. Some Bahutu also involve themselves in pottery as a sideline to supplement their income from farming.

Though the industrial sector is still relatively underdeveloped, Rwandans currently supplement their farming with small-scale production and handcrafts. Several types of handcrafts are popular: (1) traditional handcrafts which include pottery, wickerwork, ironworking, and woodworking, (2) art objects such as fine wickerwork, embroidery, ceramics, carvings, and handmade

\footnotetext{
'Ian Linden, Church and Revolution in Rwanda (New York: Manchester University Press, 1977), 236.

${ }^{2}$ Nyrop and others, 44.
} 
carpets, and (3) the service crafts which would include quarrying, tiling, shoemaking, bicycle repair, motorcycle and auto servicing.

\section{Colonial Heritage}

According to traditional folklore, when the Tutsi began arriving in the area which is now Rwanda, they gradually subjugated the Hutu inhabitants to serfdom. The Tutsi established a monarchy headed by a Mwami (king) and a feudal caste of nobles and landlords. Through a device known as Ubuhake (a contract whereby the Hutu farmers obligated their services and those of their descendants to the Tutsi lord in return for the custodianship of cattle and the use of pastures and arable land), the Hutus were reduced to a condition of subordination something like feudal serfdom. ${ }^{1}$

The German Period

In 1894, a 600-man military expedition entered Rwanda under the leadership of the German Count Adolph Von Gotzen. By 1899, Rwanda was recognized as a German protectorate. Von Gotzen strengthened the authority of the Mwami to preserve internal stability. The Germans feared the English protectors of Uganda, who they believed were trying to possess the whole of East Africa. The Belgians in control of the Congo (now Zaire) were

\footnotetext{
${ }^{1}$ Ibid., 73, 74 .
} 
also a threat because they wanted access to Lake Victoria.' The government of Rwanda permitted the Germans to station forces in the country to provide protection against possible Belgian or British aggression. In addition, Van Gotzen thought it was important "to employ all available forces so as to be ready to intervene in the contested area of the Independent state of the congo, and to ensure the building of roads."2

\section{The Belgian Period}

Anglo-Belgian troops dislodged the Germans in 1916 with oppressive assaults. Several years later the Higher Council of the Allied Powers gave Belgium the mandate over the territory. The mandate was officially confirmed by the League of Nations in $1923 .^{3}$ An alliance was established in 1931 "between the Belgian government, the Tutsi authority, and the Catholic church." 4 When the Belgians were inclined to change the political situation for the benefit of the Hutu, protest came from church

${ }^{1}$ S. E. Monsieur, ed., Rwanda, Land of Eternal Spring (Boulogne, France: Editions Delroisse, 1973), 23, 24 .

${ }^{2}$ Ibid. , 25.

${ }^{3}$ Ibid. , 27.

${ }^{4}$ Ibid. , 35 . 
leaders saying that "the Tutsi were a better choice for the conduct of Rwanda." 1

\section{Independence}

The Hutu revolution, 1957-1961, was mainly led by former seminary graduates. Tutsi leaders were aware of the gravity of the growing discontent with the monarchy and the fact that their privileges were resented. The king proclaimed that the "terms Hutu, Tutsi and Twa must no longer appear in official papers, or on school registers, and that all the inhabitants of the country had only one name: Rwandans."2 This provoked the Hutus. They contended that only by continuing the ethnic names would any real progress be shown on the social levels in Rwanda. They still considered themselves to be Hutu and wanted it acknowledged that discrimination existed.

As a result of the Hutu revolt in 1959 , independence, and a gradual shift toward a monied economy, the relationship between the Tutsi overlords and agricultural serfs has changed. According to the constitution . . . the Rwanda Republic ensures the equality of all its citizens without distinction of race, origin, sex or religion. The egalitarian base of the new government form is constitutionally reinforced: "The privileges of castes are abolished and may not be restored. No new privileges may be instituted." The right of suffrage to all nationals of both sexes is granted by the constitution. ${ }^{3}$

The theory of the new constitution received

\footnotetext{
${ }^{1}$ Ibid., 36 .

${ }^{2}$ Ibid., 37

${ }^{3}$ Nyrop and others, 75 .
} 
popular support but its application has not met the expectations of the minorities. In 1961, the people of Rwanda voted to make their country a republic. The Belgian protectorate, Ruanda-Urundi, was divided and two sovereign independent nations, Rwanda and Burundi, came into being on July 1, 1962. The people of Rwanda elected Gregoire Kayibanda as the first president. In 1973, military leaders led by Major General Juvenal Habyarimana overthrew the former government and dissolved both the National Assembly and the Parmehutu Party (established to liberate the Hutu) and abolished all political activity. President Habyarimana announced the formation of the Mouvement Revolutionnaire National pour le Developpement ${ }^{1}$ in $1975 .^{2}$ The goals of the movement are to promote peace and unity, national development, and the end of feudalism. Under the MRND the Rwandans went to the polls in December 1978 and overwhelmingly endorsed a new constitution. They confirmed President Habyarimana in his presidential duties. In the election of January 1980, progress continued toward the full resumption of civilian rule with the election of communal counselors. The political structure is essentially that of a single party republic with one legislative body. A

\footnotetext{
${ }^{1}$ Hereafter MRND.

${ }^{2}$ Republique Rwandaise Ministere Du Plan, 2eme Table Ronde Des O.N.G. (Kigali, Rwanda: N.p., 1985), 5 .
} 
recent national election, December 1988 , again reconfirmed the desire of the people for President Habyarimana to continue his plans for peace, progress, and development.

\section{Present Situation}

All three groups--Tutsi, Hutu, and Twa--prefer to be referred to as Rwandans today. Ethnic identification has been a source of great resentment for the minority groups since it was introduced by President Habyarimana. "A system of identity cards on which the tribe of the wearer was inscribed"1 was justified by the government as a way to control job quotas. Resentment among the Tutsi group was great because they were severely limited in opportunities; 85 percent of all jobs were reserved for the majority tribe members. ${ }^{2}$ In addition, the same percentage ratio has been rigidly applied to school placements.

On October 1, 1990, an estimated 5,000 to 10,000 Tutsi refugees living in Uganda crossed the border into Rwanda in an attempt to topple the government. Major General Fred Rwigyema, who had earlier assisted in President Museveni's rise to power in Uganda, led the invasion. Like most of the estimated 250,000 Rwandan

'Jane Perlez, "Rwanda Pledges Democratization," The New York Times International, 15 November 1990, A5.

${ }^{2}$ Ibid. 
Tutsi refugees living in Uganda, Major General Rwigyema was "from the minority Tutsi tribe, which the majority Hutu tribe ousted from power more than 30 years ago."1 Rwigyema was killed early in the fighting. ${ }^{2}$

The underlying cause of the invasion had to do with the return of an estimated half a million Rwandan Tutsi refugees who had been living in exile. Most had been living in neighboring countries for over 30 years. ${ }^{3}$ The rebel forces insisted that peace was possible only if the question of the refugees would be satisfactorily addressed. Since that question still has not been satisfactorily resolved (as of June 1992), turmoil continues from periodic rebel invasions and from rebel sympathizers and financial supporters both outside and within the country.

A cease-fire proposal of the Belgian government was accepted by President Habyarimana on October 18 , 1990. The proposal called "for neutral troops to supervise a cease-fire between his army and rebels invading from Uganda."4 President Habyarimana said "that

\footnotetext{
"Thousands Invade, Rwanda Reports," The New York Times International, 3 October 1990.

${ }^{2}$ Perlez, A5.

${ }^{3}$ Ibid.

4 "Rwanda Accepts Cease-Fire Plan," The New York Times International, 19 October 1990, A10.
} 
he would permit a multiparty political system next year."1 The president also stated that "Rwanda would abolish tribal names on national identity cards."2

\section{Economic Dependence within the Country}

Subsistance Economy

The significant determinant of national income is considered to be the level of export earnings. ${ }^{3}$ In Rwanda, coffee has been the major source of foreignexchange earnings, followed by tin, tea, and pyrethrum. ${ }^{4}$ In recent years the market for tin and pyrethrum has fallen off. This has made the country primarily dependent on increased output of "foodstuffs" for export. The Rwandan economy depends primarily upon peasant farmers growing food produce. Most of what is grown is consumed directly by the producers. Only a very small amount remains for marketing.

Post-independence has seen an increase in economic activity in Rwanda. However, the nation continues to be an extremely poor country. Two factors threaten the country's strong economic development: the

\footnotetext{
'Perlez, A5.

${ }^{2}$ Ibid.

${ }^{3}$ See Economic Indicators in Appendix I.

${ }^{4}$ Nyrop and others, 110, 111.
} 
scarcity of land and the rapid growth of the population. ${ }^{1}$

The secondary sector (manufacturing, processing, power, and construction) and the tertiary sector (transport, commerce, housing, Government, and other services) expanded considerably, as manufacturing and trading companies, which in preindependence period had served Rwanda from their headquarters in Burundi, established local firms. ${ }^{2}$

Since crop production has failed to keep pace with the population growth in most years since independence, the attainment of a level of stability from which economic development could be launched has become an extremely long-term process. ${ }^{3}$

Government officials recognized that future economic stability was also dependent on accelerating the rate of both public and private investment which, in turn, was contingent on the achievement of some public savings and an increase in foreign aid. ${ }^{4}$

David Lamb, in his book The Africans, includes Rwanda in the list of those countries which are highly dependent on foreign aid. ${ }^{5}$ Many nations in Africa and elsewhere have been dependent. According to the 1988 UNICEF report, "Approximately one-third of the developing-world's people live in countries which have

'Ibid., 107.
${ }^{2}$ Ibid.
${ }^{3}$ Ibid.
${ }^{4}$ Ibid., 108.
${ }^{5}$ David Lamb, The Africans (New York: Random House,
$1985),{ }^{102 .}$


experienced zero or negative economic growth in the 1980s."1

Rwanda has a $\$ 320$ annual per capita income. ${ }^{2}$ Thirty percent of urban dwellers and 90 percent of rural dwellers are below the absolute poverty level. ${ }^{3}$ The GNP per capita average annual growth rate is -1.9 percent. ${ }^{4}$ statistics indicate that Rwanda is among those countries showing negative economic growth. The government has allocated a budget for development which is equivalent to about $\$ 3,750,000$. The official development assistance being received from outside sources amounts to $\$ 181$ million (U.S.), or approximately 10.7 percent of the country's GNP.5 Virtually all new construction and capital improvements are dependent upon foreign aid. Economic dependence upon Europe and the United states is cited by the government of Rwanda as a principal obstacle to the development of the country. Europe and the United States directly provide more than 60 percent of all imports and absorb more than 90 percent of all exports from the country. Thus, the integration

'James P. Grant, The State of the World's children 1988 (New York: Oxford University Press, 1988), 25.

${ }^{2}$ See table 1 in Appendix $F$.

${ }^{3}$ See table 6 in Appendix F.

${ }^{4}$ Ibid.

5"Rwanda," Encyclopedia Britannica. 
of the geo-cultural environment is too weak. ${ }^{1}$ The feeling expressed by the Minister of Plans is that Rwanda must diversify. It needs to open markets with other African countries. During the first quarter of 1990 , ten heads of state from French-speaking African countries met in Kigali, Rwanda, to take the first steps toward a trade agreement which would enhance trade between bordering African countries.

Development of primary enterprises is limited because of the scarcity of natural resources, mainly available land, minerals, and energy. The maximum amount of land available for cultivation is 1,364,000 hectars. More than 1,260,000 hectares are under cultivation. In addition, the land-locked country has an inadequate system of export transportation by road, rivers, lakes, or air. High unemployment is difficult to solve because of the lack of expansion of secondary and tertiary enterprises. ${ }^{2}$

Industrialization has progressed very slowly for several reasons in Rwanda. The economy is still based largely on a system of subsistence agriculture. Textiles, plastics, foam, beer and soft drink production, and seasonal canning is basically the extent of its industry. Exports must be trucked through Uganda and

\footnotetext{
${ }^{1}$ Republique Rwandaise-Ministere Du Plan, 6, 7 . ${ }^{2}$ Ibid. , 7 .
} 
Kenya, or through Tanzania, to the coast for shipping. Such transporting of manufactured goods is expensive. Equally expensive is airfreighting goods. The financial investors are primarily from India and china.

Cultivation is all done by hand with imported hoe heads from china. Wages are low in the factories (mostly Indian) which allows enough profit margin to produce goods primarily for local consumption. Construction, roads, and communication in the country are almost exclusively limited to projects funded by foreign aid. Equipment is all imported and not manufactured locally. Europeans operate the few mines that are still producing exports.

In order to reduce the enclave's disadvantages of a land-locked country, the government is working to supply more of its own needs by local production. ${ }^{1}$ To increase income of families, an attempt is being made to improve methods of farming and to stimulate the development of more small industries, crafts, and services. Attention is also being given to more judicious use of foreign aid. For better control of the demographic phenomenon, which will soon see every hectare of land under cultivation, family-planning programs are being integrated into the health services of the country. ${ }^{2}$ The

\footnotetext{
${ }^{1}$ Ibid.

${ }^{2}$ Ibid. , 7, 8 .
} 
government has had to take this measure in spite of the protests of the Roman Catholic Church. The current population is in excess of 7,000,000 and by the year 2000 it is expected to climb to $10,123,000$. Doubling time has been estimated at twenty-one years. ${ }^{1}$

\section{Crisis of Financial Dependency}

A crisis of financial dependency has developed within Rwanda. The country is attempting to develop its own resources and to open markets that will help relieve the dependency problem.

National debt is causing governments to wobble under the economic burdens. There are too many who firmly believe "that only massive infusions of foreign capital and technology are capable of solving many of the basic social and economic problems."2 Inflation, unemployment, government deficits, poverty, inequality, and pollution are problems rooted in the inefficient use of resources. Since the wants of society are insatiable, and the means for producing goods and services are limited, the tendency is to look elsewhere for a solution to the problem. Instead of living within the bounds of

\section{1"Rwanda," Encyclopedia Britannica. \\ ${ }^{2}$ F. Ross Kinsler, "Extension: An Alternative Model} for Theological Education" in Learning in Context, (England: New Life Press, 1973), 35. 
available resources, the yearning consumer looks toward more distant resources.

Within Rwandan society there are those who look to the national government to solve their personal problems. This mentality is carried over into the church. Each sub-organization looks to the next higher level to provide a solution to its problems. The critical need "in these situations is not further outside help but an awakening among the people themselves as to who they are and what they can do."1

\section{Christian Missions in Rwanda.}

Early Missions

Catholic missionaries of the order of the white Fathers entered Rwanda in 1889 and established permanent missions in 1900. "The White Fathers, a French order, was founded by Cardinal Lavigerie. He formulated a realistic program for the spiritual conquest of Africa."2 His plan was to work within existing social structures to bring conversion to the tribes by converting the chiefs. The priests learned the local language but were not initially successful in reaching the ruling class. However, in time "almost all the Tutsi chieftains were converted,

\footnotetext{
${ }^{1}$ Ibid.

${ }^{2}$ Long, 41 .
} 
and with them a great mass of Hutu and other Tutsi."1

Following World War I, when the power of the Mwami and the ruling class was severely curtailed, "even members of the royal household were baptized."2 The Tutsi decision to accept Roman Catholicism had a positive influence upon the Hutu who were already responsive. "The Fathers hardly knew how to deal with this flood of interest in Catholicism." 3

Since its entrance into Rwanda the Roman Catholic church has played a remarkable role--"an economic, social and cultural role as well as a religious one. From the 1930's onwards, almost all teaching was in its hands. It carried great weight in decisions." 4

Under the law of August 27, 1966, public education in Rwanda became organized, and private education was subject to regulations. "This law allows parents to choose the school which best corresponds to the aspirations of their children."s Today, in Rwanda all government schools are Roman Catholic schools and all Roman Catholic schools are public schools.

Lutheran missionaries from Germany were the first

${ }^{1}$ Monsieur, 35.

${ }^{2}$ Long , 43 .

${ }^{3}$ Ibid , 44 .

${ }^{4}$ Monsieur, 35 .

${ }^{5}$ Ibid. , 61. 
Protestants to enter Rwanda prior to World War I. They established a mission in 1907 called the Bethel Mission, which eventually developed into a chain of mission stations. The German missionaries successfully "prepared the first translation of the Gospels into kinyarwanda. These were published by the British and Foreign Bible Society in 1914."1 This work, started by the Bethel Mission Society, was officially transferred to the Belgian Society of Protestant Missions in 1921. All German missionaries were expelled during World War I and Rwanda became a Belgian-mandated territory.

\section{Church Missionary Society}

The Church Missionary Society ${ }^{2}$ pioneered mission work in Uganda in 1877. During World War I, the CMS in Uganda was asked by the senior chaplain of the Church of England at Dar es Salaam to provide supervision for German missionary interests in occupied areas. Rwanda came under this request. Missionaries were thus sent to Rwanda by the Bishop of Uganda, J. J. Willis, to investigate opportunities for mission work. The eventual result was the beginning of the medical work at Gahini. ${ }^{3}$

${ }^{1}$ Long, 48 .

${ }^{2}$ Hereafter CMS. John Venn and Thomas Scott were the founders of the Church Missionary Society in 1799.

${ }^{3}$ Ibid., 59, 60. See Map in Appendix E. 
The Anglican church put down its roots at Gahini

in 1920. In that year

an extensive medical and evangelistic programme was begun by the Ruanda Mission (CMS), of Low Church Evangelical background. Together with the indigenous Revival Movement (Balokole, or saved Ones) since 1927, CMS has contributed towards making the Anglican church the third largest Christian community in the country. ${ }^{1}$

When CMS began its work at Gahini in Rwanda in 1920, it determined to "refrain from any open attack or polemic (against Catholics) in .. . preaching and literature."2 Instead, it was decided that the missionaries should model Christianity and allow the Holy spirit to bring conviction and conversion to the masses of people they had come to serve. The results of that strategy have been admirable as can be seen by the growth of the church.

East African revival fellowship

Gahini was the birthplace of the Balokole, or the East African Revival Fellowship. Though a missionary was involved in the inception of the movement, it was an indigenous revival within the Anglican church in Rwanda.

The revival movement grew out of frustration among Anglican leaders (1) with the lack of spiritual

${ }^{1}$ David B. Barrett, Schism and Renewal in Africa (London, England: Oxford University Press, 1986), 590.

${ }^{2} J$. E. Church, Quest for the Highest (Exeter, England: Paternoster Press, 1981), 85. 
power in the corporate Anglican church and in the personal lives of its members ${ }^{1}$ and (2) the interpretation of the teaching of the CMS on the radical sinfulness of man. Emphases on the Holy Spirit, public confession, the present heathen society, and witnessing resulted in teams of Bible workers being sent out through East Africa to spread the revival." "The real leaders of the movement seem to be Africans who feel they are specifically inspired and resent correction from anyone." ${ }^{3}$ Many church bodies in East Africa have been affected by this movement. ${ }^{4}$

Today the movement has fallen upon hard times because the adherents are accepting tenants of faith propogated by Jehovah's Witnesses advocates. The Balokole are perceived as dissidents by governments in East Africa because members would rather go to prison than serve in the military. They refuse to salute the flag of their nation or allow their children to participate in patriotic exercises. They show no deference to heads of state and political leaders. It has been stated by former missionaries that

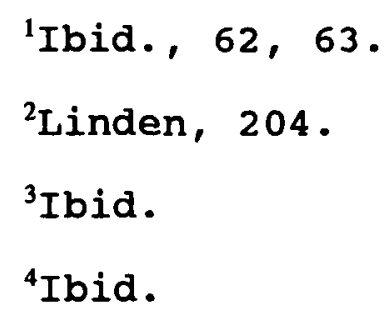


our experience in East African Revival is that splits and divisions are due to love growing cold through jealousy of leadership. By recognizing this we have been helped to avoid these splits by going quickly to the cross together in repentance. 1

Unlike other indigenous movements, the Balokole remained within the Anglican church. Although they are zealous and ardent Christians in many ways, their present message and methods of working are meeting with great opposition. Some of their adherents have accepted Adventism and work to propogate both sets of beliefs. In so doing they have brought the Adventist church under investigation by Rwandan government officials as to its basic tenets and beliefs.

\section{Seventh-day Adventist Missions}

Adventists arrived in 1919 and have steadily grown in numbers until, in the 1980s, they were second only to the Catholic church. ${ }^{2}$ The baptized membership at the end of June, 1991, was $232,502 .^{3}$ with the exception of the Adventists who are widely dispersed throughout the country, Protestantism has a regional orientation in the country. Methodists are located predominantly in the southwest; Pentecostals, near Gisenyi; Baptists, south of

\footnotetext{
${ }^{1}$ Church, 254 .

${ }^{2}$ Barrett, World Christian Encyclopedia, 589.

${ }^{3}$ See Appendix A.
} 
Butare; and Presbyterians, near Kigali.'

Early history

The Seventh-day Adventist work began with the efforts of a young Belgian worker, D. E. Delhove. He had been drafted into the Belgian Army where he did clerical work during the war years. His military responsibilities took him into Rwanda.

Impressed by the beauty of the country and the intelligence of its African inhabitants, he became convinced that this would be a fruitful field for SDA mission endeavor. ${ }^{2}$

Joined by Henri Monnier after the war, Delhove and Monnier made a trip to the government headquarters in Rwanda. "They were promised all the late German missions in Ruanda. With this hope in view they started work." 3 After working for twenty months at kirinda (one of the earlier Lutheran missions he had been promised) and awaiting final authorization to possess the other former German missions, rumors began to circulate that the missions had been handed over to the Belgian society of Protestant Missions. Delhove immediately went to visit

'Barrett, World Christian Encyclopedia, 590.

${ }^{2}$ Don F. Neufeld, "Rwanda," Seventh-day Adventist Encyclopedia, (1966), 1101.

${ }^{3}$ Lydie M. Delhove, A Daughter Remembers D. E. Delhove (Canon City, Co: Master Printers, 1984), 19. 
the District commissioner and discovered that the rumors were true. ${ }^{1}$

As Delhove set about in search of a new mission site, he came across a two-mile-long hill where villagers dumped dead corpses. From his investigation of the desolate hill he learned the following story:

Once upon a time many years before, the king of Ruanda was returning to his palace after a mission of death. When a storm broke out, suddenly and fiercely (like it can often do in tropical Africa) he got drenched. Humiliated and enraged, he turned and faced the hill. He summoned the spirits of his ancestors and called down the curse of the gods upon the hill. This meant that whoever of his subjects would ignore his curse would surely be bewitched. Immediately all inhabitants deserted the cursed hill and as time passed, not even a tree was growing on it. The name of the hill was Gitwe (the place of the skull) because of the many human skulls which had accumulated over the years. ${ }^{2}$

Delhove was convinced that the hill was where the Lord wanted the mission station located. Upon request he was given the 125-acre site. This plot of ground, Delhove reasoned, would in time bring a blessing out of a curse. ${ }^{3}$

However, the work did not proceed rapidly. Christianity was not immediately accepted. The indigenous people gave much resistance to the education of their children. They were afraid of whites whom, for the

\footnotetext{
I'Ibid., 20, 21.

İbid., 21 .

${ }^{3}$ Ibid.
} 
most part, they were seeing for the first time. When children were sought as prospective students, their parents would hide them with relatives and friends. No amount of persuasion could change the minds of the parents.

While Delhove was developing the work at Gitwe, Henri Monnier and A. A. Matter located another mission site at the foot of Rwankeri Mountain, which they developed together. Within a short time, however, Matter and his family went on furlough leaving Monnier and his young daughter, olive, alone to carry forward the new work.

Monnier, of Swiss origin, had been bereaved of his wife five months after the birth of his daughter. For a period of time the Delhoves had cared for Olive. But Monnier was too lonely being separated from her. Olive was his only white companion. After a time he became sick and was instructed to return to Switzerland to receive medical attention and find a new wife. One year later he returned to Rwankeri with his new wife, olga Pavlov, who was a trained nurse and Bible worker. ${ }^{1}$

The fire of early evangelism

Adventist evangelistic and educational work in Rwanda really began with adherents of the former German

${ }^{1}$ Ibid., 24. 
Protestant missions. The first adherents to Adventism were immediately involved in evangelism. No one was exempted from evangelistic work. Even the cooks at the schools participated. Each person was to do what he/she was able to do. Church members sometimes traveled between 50-100 kilometers to evangelize unentered areas. Teacher-evangelists were appointed to teach, preach, and baptize. They also collected the tithes and offerings and brought them to the storehouse. ${ }^{1}$

Henri Monnier began a revival in Rwankeri which resulted in that area becoming a leading source of church workers. In 1925, he opened a school, at which many future leaders in the church were trained.

Pastor Harold E. Guillebaud was assigned by the CMS to translate the entire Bible into Kinyarwanda in 1925. Through collaboration with other missions and missionaries, the project was carried forward. Henri Monnier represented the SDA church to the Bible Society and cooperated in the work of translation which would eventually make the entire Bible available to the peoples of Rwanda in their national language. ${ }^{2}$

${ }^{1}$ Manasse Mugemana, "Evangelistic Methods Used by Adventists in Rwanda," (Unpublished rough draft of SDA Church History in Rwanda, 1989), 3. Available from the author in Kigali.

${ }^{2}$ Michel Twagirayesu and Jan van Butselaar, eds., Ce don que nous avons recu (Kigali, Rwanda: Eglise Presbyterienne au Rwanda, 1982), 103. 
In 1931 Gitwe became the teacher-training school for the Ruanda-Urundi Station. R. L. Jones arrived in 1934 to become the Director of the Gitwe Mission and the Training school. Gitwe took on added importance in 1935 when it became known as Seminaire Adventiste de Gitwe. It began to train future workers for the entire congo Union of which Gitwe is a part. ${ }^{1}$

During the latter part of the 1930s, Jones together with C. W. Bozarth, the Union president, initiated an active lay-training program which changed the concept of evangelism in Rwanda. Previously denominational workers had been the primary instruments of evangelism. Knowing that only meager results would continue if the work of evangelism depended upon the teachers and evangelists, Jones and Bozarth began a serious training program of the laity. ${ }^{2}$

Rapid expansion of the work necessitated the separation of the Gitwe Mission from the school in 1947. One district remained attached to the school for the purpose of having nearby churches for those in ministerial training. Evangelism no longer rested upon the shoulders of teachers and evangelists alone--laymen

\footnotetext{
${ }^{1}$ Mugemana, 2 .

${ }^{2}$ Ibid. , 3 .
} 
were now being trained as active evangelists. ${ }^{1}$

Evangelism explosion

By the 1950s a comprehensive work of evangelization was implemented. Training schools, or outschools, of evangelism were established, and many workers were sent out to open them. "After establishing a mission station, the missionaries surrounded it soon with either outschools or small stations. So it was not an island in a heathen sea but it helped expand the range of action."2 Week-long training sessions were conducted at the outschools. Methods of lay preaching, home visitation, preaching, denominational history, doctrinal subjects, principles of hygiene and home nursing, and how to give Bible studies were covered in the instructional periods. Training schools were held in churches, private homes, shelters, and under the trees or wherever church services were conducted. Some of the schools taught the first three grades of school in the mornings and conducted Bible studies in the afternoons. One- and two-month evangelistic campaigns were conducted by workers and laymen. Laymen would go out in pairs for two weeks and would be replaced by another pair who would continue another two weeks.

${ }^{1}$ Gitwe college notes provided by former Director of Gitwe, Aaron Nzahumunyurwa. Dated July 12, 1988.

${ }^{2}$ Mugemana, 3 . 
61

Laymen also were chosen by local church committees to participate in the opening of the training schools. Since many untrained lay members were going out on their own, the local field committees were concerned that reliable trained laymen be chosen as teachers. Criteria for leadership were established to maintain the integrity of the schools, 400 of which were established in the Gitwe area alone. ${ }^{1}$

Salaries were not paid to the laymen. Some were given tax money in exchange for eight months of work. The tax compensation was a compassionate assistance to those not able to participate in the family sustenance for prolonged periods of time. However, the lay workers were not primarily motivated by material gain. The concept of every-member involvement in evangelism had simply caught fire in the hearts of these believers. ${ }^{2}$

School principals were required to do evangelism as a part of their job description. They organized and coordinated evangelistic outreach. Every local member was asked to bring one person to the weekly church services. The training schools became evangelistic centers. Bible correspondence school lessons were initiated. The selling of Christian literature became a requirement for every ministerial student. Seven-day

\footnotetext{
${ }^{1}$ Ibid., 6.

${ }^{2}$ Ibid.
} 
lay-training programs were held to instruct members how to give Bible studies and to preach. Every week some evangelistic outreach was in process. At one point, Division president Elder R. S. Watts told the Union officers not to open any new work for at least a year because of organizational problems and lack of personnel. The Union committee recognized that

WHEREAS the steady and fast growth of our church membership and the tremendous influx of new converts into the Hearers and Baptismal classes creates almost insurmountable problems for the small European and African working force to properly shepherd the numerous adherents and to conduct a good progressive school program, and

WHEREAS such a situation can endanger the stability and structure of our mission program,

VOTED: (1) That no new schools be opened and no unpaid teachers be employed without authorization from the Union committee;

(2) That each Mission committee give study in consultation with the Mission Educational Secretary, Station Directors, Travelling Pastors, and District Leaders to the possibility of combining as many MV schools as possible into regular schools, and that definite plans of locating and financing such schools be prepared and presented to the year-end committee;

(3) That a special commission be appointed to study the educational system and teachers' training program in the congo Union Mission.

A leadership crisis had developed. Concern was expressed that the entire mission structure could be endangered unless adequately trained leaders were available. All workers were instructed not to open any new

\footnotetext{
${ }^{1}$ Congo Union Mission Minutes (Fizi, Congo), Action 450/57, September 27, 1957.
} 
schools. However, laymen continued to extend the work to the unreached areas.

Burton Wendell, Central Rwanda Field president during the 1950s and Director of Gitwe College during 1957-1958, states that the Division president counseled them not to open work in any new areas. But he had a pastor, Gideon Bandora, who for evangelistic purposes organized the transfer of forty families from their homes to new areas where they had received land from the local chiefs. They held reading schools for grades one and two in the mornings, did evangelistic visitation in the afternoons, and began Sabbath services. ${ }^{1}$ Every effort was made to move into unentered territories.

Evangelistic fervor dampened

What committee action could not effectively stop was eventually dampened to a degree by a shift of emphasis. Through the 1970 s and the 1980 s a new mentality developed. The trained pastoral ministry was perceived by members as a professional ministry. In other words, pastors were viewed as those paid to do the work. Members began to assume observer-only status. School schedules, now structured by the government, were filled with required courses. Teachers and students could no longer give evangelism a strong emphasis. As a

\footnotetext{
${ }^{1}$ Burton Wendell, retired missionary, to author, June 6,1988 .
} 
result, spirituality in the schools quickly began to decline.

As the emphasis on training for evangelistic endeavor abated, there was a corresponding decline in church standards. When outreach through the training schools ceased, training of new adherents also suffered. The role and function of the pastor as an equipper, trainer, and enabler was lost sight of completely.

Influence of traditional society and religion

Almost all of the new adherents came from the traditional primal religion. Because of limited instruction prior to membership, these new adherents have tended to blend their traditional beliefs with Christianity. Many lack a clear understanding of grace and tend to interpret natural calamities as punishment from God as a result of moral offenses that have been committed. The same is true of diseases and accidents. ${ }^{1}$ Moral values of many of the new adherents are strongly conditioned by social practices. The moral values upheld by the church are important religiously but change in the minds of many of the new adherents as their living conditions change. ${ }^{2}$ some of the new adherents

\section{'John S. Mbiti, Introduction to African Religion} (London, England: Whitstable Litho, 1981), 181.

$$
{ }^{2} \text { Ibid. , } 11 .
$$


bargain in their religious practices. If they offend in one area, they will compensate in another area. When school attendance is compulsory on the Sabbath, many will rationalize that their children are being prepared for future service to God. If a member has a moral lapse with adultery, dishonesty, or alcohol, it is acknowledged that the member has a weakness in that area and the weakness is accommodated rather than the member labored with or disciplined.

The poorly trained leaders in Rwanda have been unable to adequately instruct and prepare new adherents from the traditional backgrounds. So the new adherents hold on to many of their former thought patterns and practices which are detrimental to Christian growth and development.

In Rwandan families there is a hierarchy based on age. The older family members enjoy a higher status than the younger members. When prominent older members with high social status experience moral lapses, it is very difficult to bring church sanctions against them. Fear of reprisal will often cause leaders to avoid the question of church discipline against an influential member. If conscientious members insist that such members should be disciplined, they are quickly labeled extremists and fanatics.

In traditional Banyarwanda religion, morality was determined by what tradition defined as good or 
bad. The guardians of this system of morality were the ancestors, the elders of the community, and the diviners. The essence of Banyarwanda morality was more social than spiritual. ${ }^{1}$

The scriptures replaced the traditional sources of moral authority when the adherents embraced Christianity. Yet, many of the traditional practices have been carried over into the church because of poorly trained leaders who are unable to properly prepare new adherents.

Trained leaders are needed today who clearly understand the teachings of scripture. They need to be mature leaders who have already gained the confidence of the church members. They need to be educated and spiritually attuned leaders who can adequately meet the needs of the local rural congregations.

\section{Dependency of the Church}

The church must look to new ways to develop its resources. A crisis of financial dependency has developed within the church just as it has in the country. It has been stated by J. E. Church that

Money and the cost of living have begun to dominate the lives of developing Africa like the tentacles of an octopus, getting men in their grip with borrowing, debts, muddles, misappropriations, and one that cannot be avoided--school fees. ${ }^{2}$

When the Belgian government initiated a reformed

\footnotetext{
${ }^{1}$ Long, 145 .

${ }^{2}$ Church, 250, 251 .
} 
six-year secondary school program in Rwanda in the early 1980s, revised education grants, regulations, and pay scales for teachers were also included. Acceptance of grant monies necessitated the implementation of new rates of pay for all teachers and medical workers. A disparity between the salary scales of teachers and medical workers and those of local pastors was immediately created. ${ }^{1}$

Local congregations were unable to increase their giving to the degree needed to meet school-recognition requirements of the government. Without the recognition--which means that schoolroom sizes, building conditions, equipment, and teacher qualifications meet government standards--students would not be given diplomas. Patrons of Adventist schools immediately looked to the higher church organizations to rescue them from the pressures of funding christian education. Meeting the government standards was costly.

The imposed new standards of education were not anticipated by the patrons of the schools. Years of dependency made it a natural response for the constituents of the schools to request help from outside. No serious effort was made towards internally solving the newly created problems. Consequently, when outside church assistance was insufficient to meet the demands of recognition, most Adventist schools closed.

\footnotetext{
${ }^{1}$ Ibid., 251.
} 
As the country is attempting to develop its own resources and to work toward reducing its dependency, in a similar way the church must look to new ways to provide for its own present and future needs.

\section{Urbanization}

Urbanization has not been significant in Rwanda. The effects of urbanization in the USA are "overcrowding, extreme poverty, lack of facilities and high unemployment."1 These factors result from a conscious shift from the rural to the metropolitan centers. In Rwanda this shift has been minimal.

Kigali, the capital city, is estimated to have a population of approximately 350,000 people. Other major cities, which are basically market centers, do not exceed 30-40,000 people. The density of the population allows people to live on their small pieces of land and carry their produce to nearby centers for marketing. The inner-city effect and resulting social decay experienced in the USA is not experienced in Rwanda. Few squatters' areas can be seen anywhere in the country.

However, the density of the people throughout the nation has produced similar effects to those of urbanized areas. Overcrowding tends to result in violence and

${ }^{1}$. Edward Turner, "Pastoral Care as a Factor of Church Growth," in Servants for Christ: The Adventist Church Facing the '80s, ed. Robert E. Firth (Berrien Springs, MI: Andrews University Press, 1980), 148. 
apathy. When people experience a lack of personal space there is a reaction toward survival behavior. There is also an attitude of hopelessness that develops from the inability to change social structures. All of the above are presently being experienced in Rwanda.

TEE would offer hope to many of the hopeless. It would provide an antidote to much of the growing violence that is plaguing the country. The principles of scripture are the most powerful tools to use in constructing a better society. War has given increased feelings of hopelessness and discouragement. It has had a devastating impact upon the entire nation. Schools and business operations have been interrupted for days and weeks at a time. The social climate is ripe for the proposed TEE program.

\section{Secularization}

There are four basic focal points in the process of secularization in the west that are apparent as it impacts personal and social structures:

1) It is concerned for the temporal as opposed to the eternal. The secular person affirms the thisworldly' way of existence. 2) Everyday activities are of greater concern than religious activities. 3) Knowledge is gained by the rational endeavor of men and women. In opposition to this is Christian revelation which, to the secular mind, appears illogical and part of an old-style metaphysics. 4) The secular person conceives of himself or herself as an autonomous being. Nothing transcends the human sphere. Norms and support come from within the self. This autonomous life is contrasted with the life of faith, 
which is one of dependence, partnership and cooperation. 1

Secularization turns the focus of a person

inward. Self-concerns become the center of focus while the needs of others are disregarded. The breakdown of the family is the natural by-product. Secularization places a temporality upon marriage: "Not only has the institution been downgraded, but lifelong fidelity and commitment are viewed as outdated notions."2

Since Rwanda has remained largely an underdeveloped Christian culture, secularization has not had the impact on this small developing country that has been apparent in Western society. Television has not yet officially entered the country. Social and spiritual needs are primarily met through worship and religious activity. The government, predominantly Catholic, has been strongly influenced by the church. Religion has continued to be an integral part of the culture.

Pressures are mounting to bring in national television. Western influences are greatly influencing styles and fashions in the urban centers. Temporal concerns are becoming more noticeable as the level of education increases. Many graduates allow their secular employment to take precedence over religious concerns.

\footnotetext{
${ }^{1}$ Ibid., 148, 149.

${ }^{2}$ Ibid., 149 .
} 
Though they are the best-educated and trained resource of the church, their personal interests and ambitions have robbed the church of their contribution. Now the push for a multi-party system has increased the interest of young and old alike in political issues and involvement.

\section{Ministerial Training}

Industrialization, urbanization, and secularization have not had the strong negative effects in Rwanda that they have had in some other developing countries. This is fortunate since strong ministerial leadership, needed to help curb those rising negative influences, has not been available.

The ministerial entry-level course begun at Gitwe College in 1968 as a two-year pastoral training program in French was discontinued in 1981. The new AfricaIndian Ocean Division voted to restrict hiring of pastors to those with university diplomas. ${ }^{1}$ one of the main positive reasons for a B.A.-level trained minister was to standardize salary levels so that the Division did not have various levels of pay scales. In some places there were as many as five or six scales. Another reason for the B.A.-level requirement was to elevate the education level of ministers to enable them to effectively minister

${ }^{1}$ Africa-Indian Ocean Division of Seventh-day Adventists Working Policy (Accra, Ghana: Advent Press, 1988), 405 . 
to the better educated-people in society.

Some national workers have felt that the action taken by the Division was unrealistic and unhealthy. Their reasoning was that a great number of the church members live in rural areas and have extremely modest educational backgrounds. While these people could be reached and nurtured in the faith by properly trained university graduates, most graduates would not want to return to these rural areas. These fears of the national leaders have been well-founded--such has proved to be the case with some of the university graduates, mostly nonministerial. When new graduates have been asked by administrators to take rural assignments, various excuses have been given for not being able to work outside the urban centers. A few have even refused to continue their employment if they were required to take the rural appointments.

Because of the above problem, some leaders have felt it would be far more cost-effective in the immediate future to have a dedicated, hard-working cadre of pastors trained at a lower level.

\section{Statistical Projections}

The challenge is rapidly increasing to train suitable leaders for rural and urban coverage. AUCA serves all French-speaking countries of Africa and the islands of the Indian Ocean. Seventeen different 
countries are represented in the student body. Enrollment for the 1989-1990 school year can be seen in table 2 (appendix G).1

The forty-six theology students listed in table 2 came from many French-speaking countries. Though the number has increased from nineteen and fourteen, in 19871988 and 1988-1989 respectively, it is still an elitist few that are receiving training. statistical projections indicate that the number of members per pastoral worker is steadily increasing in Rwanda. ${ }^{2}$

The projected number of pastoral graduates from AUCA, over the ten-year period 1990 to 1999 , that would benefit RUM would be 106. Anticipated retirements of present pastors would be fifty-seven over the same period of time. This means that RUM would have a net gain of forty-nine to their present pastoral staff by the year $20000^{3}$

The growth rate of the Rwanda Union over the tenyear period 1981 through 1990 has averaged 7.73 percent per year. ${ }^{4}$ Projecting a 7.5 percent growth rate per year until the year 2000 would give a membership of $425,486.5$

'See AUCA Enrollment Figures in Appendix G.

${ }^{2}$ See Projections in Appendix D.

${ }^{3}$ Ibid.

${ }^{4}$ See Rate of Growth in Appendix A.

${ }^{5}$ See Projections in Appendix D. 
This would increase the current member-to-pastor ratio from the present $1: 1,264$ to $1: 1,750 .^{1}$ To maintain the 1989 (unsatisfactory) ratio of $1: 1,040$ would require appoximately 409 pastors rather than the current projection of 243 by the year 200--in other words, a shortage of 166 pastors.

It would certainly be expected that the 106 AUCA graduates would be better qualified and more productive than the fifty-seven retiring pastors. However, even university-trained pastors would be hard pressed to adequately fill the void created by a shortage of 166 pastors.

The reality of the problem is that the church in Rwanda needs trained leaders. More leaders are needed than the current system of pastor training can prepare. There are simply not enough candidates being trained. In addition, those needing the training should be leaders who are close to the people. Most candidates receiving pastoral training now have gone directly to the university from secondary school. They are not seasoned leaders who have gained the confidence of the church members.

What is needed is a new approach to leader training. An approach must be devised which will address

\footnotetext{
${ }^{1}$ Ibid.

${ }^{2}$ See Ratios in Appendix B.
} 
the reality of the current problem. Ministry in context must be the goal. Candidates must be selected who can be trained while they continue to give leadership in the churches.

Adventist Education and Training

Statistics indicate that there were 793,481 students enrolled in 5,322 schools operated by the SDA church world-wide in $1987 .^{1}$ Primary schools numbered 4,583 ; secondary schools, 655; and colleges and universities, $84 .^{2}$

In 1989 SDA schools in Rwanda enrolled 11,475 students in thirty-one primary schools, 807 in three secondary schools, and 322 in one tertiary school. ${ }^{3}$

The SDA membership in Rwanda at the end of 1990 exceeded 223,000.4 Estimating conservatively that there are 25,000 families represented by the membership figures and that each family has an average of five children to educate, there would be 125,000 children needing places in school. It can readily be seen that only a small

${ }^{1}$ Seventh-day Adventist Yearbook (Hagerstown, MD: Review and Herald Publishing Association, 1989), 4.

${ }^{2}$ Ibid.

${ }^{3}$ Africa-Indian Ocean Division (Abidjan, Ivory Coast), Minutes of Year-end Division Meetings, November 13-15, 1989, meeting of November 15, 1989.

${ }^{4}$ See Appendix A. 
percentage of Adventist members in Rwanda have their children's educational needs met in Adventist schools.

The fundamental principles of Christian education and training set forth in the books written by Ellen $\mathrm{G}$. White have for decades guided SDA parents and teachers. She wrote the following regarding the essential knowledge to be given to children:

The science of salvation, the science of true godliness, the knowledge which has been revealed from eternity, which enters into the purpose of God, expresses His mind, and reveals $\mathrm{His}$ purpose--this Heaven deems all-important. If our youth obtain this knowledge, they will be able to gain all else that is essential; but if not, all the knowledge they may acquire from the world will not place them in the ranks of the Lord. They may gather all the knowledge that books can give, and yet be ignorant of the first principles of that righteousness which will give them characters approved of God.'

The following statement of mission of Andrews University adequately reflects the basic philosophy of SDA schools:

Andrews University, established by the Seventhday Adventist Church in order to prepare church leaders, laity, and other responsible citizens to fulfill the Gospel Commission, is committed to providing high quality christian education in the context of the Adventist faith. It welcomes from all nations and other faiths students who meet the qualifications established by the institution and who subscribe to the ideals of the University.

Andrews University offers a variety of programs leading to vocational certificates and associate, baccalaureate, master's, and doctoral degrees. These programs are initiated and maintained, particularly

${ }^{1}$ Ellen G. White, Fundamentals of Christian Education (Nashville, TN: Southern Publishing Association, 1923), 14 . 
at the graduate level, where sufficient need exists within the Church. Along with emphasizing excellence in teaching, the University encourages research in order to enrich the learning process and to benefit the Church and society at large.

Because of its commitment to service, the University and its personnel are involved in local, national, and international programs insofar as expertise and resources allow. The first priority in the allocation of institutional resources, however, is meeting the needs of on-campus students and programs. ${ }^{1}$

The above statement of mission recognizes several limitations: (1) programs are initiated and maintained where sufficient need exists within the church and (2) that programs offered are subject to the expertise and resources available.

The SDA church in Rwanda has a unique need which has not been met through traditional educational approaches. A residence-program approach alone is not sufficient. The rapid rate of accessions to the church combined with a rising apostacy rate is approaching crisis proportions. Danger of doctrinal confusion is a present concern. Schisms and offshoot elements are becoming a menace to the church.

Membership growth is primarily among the youth. These new adherents are not only young and inexperienced, but they have been members for a relatively short period of time. More mature members, who are actually leading the local congregations, are perplexed as to how they can

1The Undergraduate colleges 1989-1990 Bulletin (Berrien Springs, MI: Andrews University, 1989), 7 . 
harness the zeal and vitality of the youth. These more mature church leaders lack the skill and knowledge of responsible leadership. A program of training must be initiated which will extend training to the recipient by such means as will best accommodate his contexual setting and situation within allowable expertise and resources.

Adventist Training of

the Laity

The world population exceeds five billion people. ${ }^{1}$ The Gospel Commission encompasses the whole of the world. It assigns to christ's followers the making of disciples from all nations by preaching the everlasting gospel in the setting of Rev 14:6-12. It teaches the restoration of the image of God in humanity, and thus the simple and humble lifestyle of its adherents gives credence to its proclamation.

Adventists believe that they have a special mission in restoring neglected truths concerning the Sabbath, healthful living, and the pre-advent judgment. Thus, the aim of every church member and entity is to minister holistically to men and women by addressing their physical, mental, social, and spiritual needs. The church seeks to model its ministry after Christ's. Just as God identified with the human race through the

'David B. Barrett, "Annual Statistical Table on Global Mission: 1992", International Bulletin of Missionary Research, January 1992, 27. 
incarnation of Christ, so we too must place a presence in every corner of the world to give opportunity for every person to respond to God's saving grace.

Adventist churches are attempting to provide Christian training for the families of their constituent members. Members are trained in witnessing skills and encouraged to use their time, talents, and resources to reach the millions yet to receive the Gospel invitation. Friends, neighbors, and working companions are the first objects of focus; next comes casual acquaintances. Then the ethnic, language, and country barriers are to be scaled. Each person is challenged to regularly tell another person about Jesus.

The SDA church has a working presence in over 200 of the 215 world nations defined by the United Nations. More than 7,757 stations air Adventist programs weekly. Printed materials from fifty-seven SDA publishing houses are produced in 189 languages. Through 30,711 churches, more than 5,000 schools, 159 hospitals and sanitariums, 329 dispensaries and clinics, and seventy-four retirement centers and orphanages, the SDA church is working to make disciples for Jesus Christ. ${ }^{1}$

A select few SDA members in Rwanda benefit from the SDA schools. A few of the members benefit from the

${ }^{1}$ General Conference of Seventh-day Adventists, 127th Annual Statistical Report 1989 (Silver Spring, MD: General Conference of SDA, 1989) 
specialized training given at the Adventist Training Center in the capital city. The center was purchased in 1989 for the express purpose of continuing education for pastors, educational upgrading of local church leaders, and training of the youth in witnessing skills. The center has also become the temporary location of the Literature Ministry Seminary where members are trained in Christian Salesmanship skills.1

When Lazarus was dead, Jesus did not command the angels to remove the stone. It was human hands that took the stone away.

Thus Christ would show that humanity is to cooperate with divinity. What human power can do divine power is not summoned to do. God does not dispense with man's aid. He strengthens him, cooperating with him as he uses the powers and capabilities given him. ${ }^{2}$

Properly understood, the Gospel Commission presses every Christian into service. It is anticipated that the proposed TEE program in Rwanda would facilitate the reaching of the unreached through graduates trained to win and train others. Training and education would be extended to a much larger number of members than can be currently helped with present programs. Graduates would be expected to start new churches and train suitable Schedules.

'See Appendix $J$ for Sample Training Session

${ }^{2}$ Ellen G. White, Desire of Ages (Mountain View, CA: Pacific Press Publishing Association, 1940), 535. 
81

leaders for each. TEE would train the most qualified laymen to be leaders in Gospel work. It would train those spiritual leaders who have already proven themselves in ministry. 
CHAPTER III

\section{ADVENTIST MINISTRY MODELS}

\section{Biblical Models for Adventist Ministry}

It has been stated that "the institutions of human society find their best models in the word of God."I In the Garden of Eden, where human history began, God established a system of education that "was to be a model for man throughout all aftertime."2 The first family was made "a little lower than the angels." 3 They lived in a perfect environment. Their garden home was the classroom. The book of nature was the textbook. They were the students and "the Creator Himself was the instructor."4 Education was family centered.

\section{old Testament Education and Training}

The narrative of Scripture states that "God created man in his own image, in the image of God created

${ }^{1}$ White, Fundamentals of Christian Education, 95.

${ }^{2}$ Ellen G. White, Education (Mountain View, CA:

Pacific Press Publishing Association, 1942), 20.

${ }^{3} \mathrm{Heb} 2: 7$.

${ }^{4}$ White, Education, 20. 
he him; male and female created he them." Immediately, God gave instruction and responsibility to our first parents. They were to have dominion over the new creation. When they looked upon their Eden home for the first time, God told them "to dress it and to keep it."2 The earliest recorded education involved work and study.

\section{Relationship of Education}

to Redemption

Though man sinned, God did not forsake him.

Redemption was promised in the curse that was pronounced upon satan. "I will put enmity between thee and the woman, and between thy seed and her seed; it shall bruise thy head, and thou shalt bruise his heal." ${ }^{3}$ God in mercy revealed a plan for man's redemption. Both education and redemption derive their highest meaning through God's saving activity.

To restore in man the image of his Maker, to bring him back to the perfection in which he was created, to promote the development of body, mind, and soul, that the divine purpose in his creation might be realized--this was to be the work of redemption. This is the object of education, the great object of Iife. ${ }^{4}$

\footnotetext{
${ }^{1}$ Gen $1: 27$.

${ }^{2}$ Gen $2: 15$.

${ }^{3}$ Gen $3: 15$.

${ }^{4}$ White, Education, 15, 16.
} 
The School of the Exodus

After the fall, family-centered education

continued. When Israel came out of Egyptian bondage, God reminded them that His laws were to be in their heart. "And thou shalt teach them diligently unto thy children, and talk of them when thou sittest in thine house, and when thou walkest by the way, and when thou liest down, and when thou risest up."1 Every activity of life was to be an occasion for instructing children in the will of God and His plan of redemption. The parents were responsible before God to provide model training and instruction that would keep the hearts of their children faithful to God.

\section{The Schools of the Prophets}

As time passed "the Israelites surrounded themselves with temptations that few had power to resist." 2 The plan that God had given for the training within each family was not perfectly followed. Soon carelessness became indifference to God's instructions. In order to help the parents with the education of their children, God directed Samuel to establish the schools of the prophets. "If a youth desired to search deeper into the truths of the word of God, and to seek wisdom from

\footnotetext{
${ }^{1}$ Deut $6: 7$.

${ }^{2}$ White, Education, 45 .
} 
above, that he might become a teacher in Israel, these schools were open to him."l These schools were to train leaders who would work against the spread of corruption and the destruction of moral standards. The graduates were to work to encourage faithfulness to the teachings God had committed to His people.

\section{Location of the Schools}

Two schools begun during Samuel's time were at Ramah, where Samuel lived, and Kirjath-jearim, where the ark was located. The schools that Samuel established fell "into decay during the years of Israel's apostasy. Elijah re-established these schools, making provision for young men to gain an education that would lead them to magnify the law and make it honorable."2

Three centers of training established by Elijah were located at Gilgal, Bethel, and Jericho. Elijah visited these schools with Elisha just prior to his being taken to heaven. Biblical references may indicate rural location sites in close enough proximity to the above centers to be called by their names.

"It is evident that the schools of the prophets were located in the country. Such expressions as

${ }^{1}$ Ellen G. White, Patriarchs and Prophets (Omaha, NE: Pacific Press Publishing Association, 1952), 593.

${ }^{2}$ Ellen G. White, Prophets and Kings (Mountain View, CA: Pacific Press Publishing Association, 1960), 224 . 
'fields,' 'hills,' 'groves,' are used in describing these schools." While Elisha was at Gilgal he gave instruction to his servant to feed the sons of the prophets that he was lecturing. "And one went out into the field to gather herbs." ${ }^{2}$ After samuel anointed Saul, Saul continued on his journey, "and when they came thither to the hill, behold a company of prophets met him."3 Samuel had told him these prophets would come down from "the high place."4

The schools were placed in strategic locations to facilitate attendance and training. Accessibility and learning environment were important considerations.

\section{The curriculum of study}

In the schools of the prophets a work-study program was followed that required each child to learn a trade. The primary subjects taught were the law of God, the instructions given to Moses, sacred history, sacred music, poetry, Hebrew language as a sacred tongue, how to pray, how to understand and obey the teachings of God, how to exercise faith in God, and how to approach their

\footnotetext{
1"The Schools of the Prophets", True Education, 1, No. 18 (July 15, 1927): 2 .

${ }^{2} 2$ Kgs 4:39.

${ }^{3} 1$ Sam 10:10.

${ }^{4} 1$ Sam 10:5
} 
Creator God.' Many of the instructors provided their own means of support by manual labor. Teachers modeled what the students were expected to learn. Work was not to be viewed as degrading. Rather, it was to be considered "a crime to allow children to grow up in ignorance of useful labor."2 In fact, every child, "whether his parents were rich or poor, was taught some trade. Even though he was to be educated for holy office, a knowledge of practical life was regarded as essential to the greatest usefulness." 3

\section{New Testament Education and Training}

The Education of Jesus

The Gospel narrative tells us that from childhood "Jesus increased in wisdom and stature, and in favour with God and man." 4 His mother followed the scriptural injunction to "train up a child in the way he should go." Ellen White indicates that "Through the Holy Spirit she received wisdom to co-operate with the heavenly agencies in the development of this child, who

\footnotetext{
'White, Fundamentals of Christian Education, 97. ${ }^{2}$ Ibid.

${ }^{3}$ White, Education, 47 .

${ }^{4}$ Luke $2: 52$.

${ }^{5}$ Prov $22: 6$.
} 
could claim only God as His Father."1 His education was received at His mother's knee rather than at the schools of the rabbis. "Since He gained knowledge as we may do, His intimate acquaintance with the Scriptures shows how diligently His early years were given to the study of God's Word."2 Nature was His second textbook of study. He also learned the carpenter trade. He knew what it was to be a common laborer. A work-study program was essential to His education as in the schools of the rabbis where work was part of the curriculum.

\section{The Master's Plan}

When Jesus began His public ministry, His first work was the training of disciples. The commission He gave His disciples (Matt 28:18-20) indicates His expectations of a disciple. A disciple is "a follower, who is taught, who is nurtured in the faith, who in turn goes out to make disciples, who are then taught and nurtured in the faith, who then in turn go out." 3

The strategy of Jesus involved the multiplication

of followers. His method became the strategy of the early church. Every disciple was a witness. Witnessing was not a conscious, planned activity that the disciples

\footnotetext{
${ }^{1}$ White, Desire of Ages, 69.

${ }^{2}$ Ibid. , 70 .
}

${ }^{3}$ Win Arn and Charles Arn, The Master's Plan (Pasadena, CA: Church Growth Press, 1982), 20. 
received special training to perform. Witnessing was a normal dimension in the life of the follower of Christ. Receiving Christ, His Holy spirit, and baptism was what qualified the new disciple to witness. That is why immediately before Jesus ascended into heaven He stated in the declarative form $\mathrm{His}$ expectations of $\mathrm{His}$ faithful followers, "Ye shall be witnesses unto me both in Jerusalem, and in all Judaea, and in Samaria, and unto the uttermost part of the earth."1 "Had Christ used the imperative verb 'to be,' it would have implied a conscious activity or planned action." 2

Make disciples

The first step in New Testament training was the making of disciples. The early church was constantly expanding its base of followers. Win and Charles Arn identify this step as the first of nine that the early church followed in order to achieve its remarkable success. ${ }^{3}$ New believers recognized that they individually had a ministry to perform. Paul's words to Archippus spoke pointedly to every baptized believer: "Take heed to the ministry which thou hast received in

$$
\begin{aligned}
& { }^{1} \text { Acts } 1: 8 \\
& { }^{2} \text { Arn, } 20 . \\
& { }^{3} \text { Ibid., } 21 .
\end{aligned}
$$


the Lord."1 These words seem to summarize the individual and corporate responsibility of the members in the body of Christ. Ayres states that "the church does not make clear what the Bible goes to great lengths to emphasize: all baptized members are ministers. The church has concentrated on the ordained ministry and all but forgotten the lay ministry."2

New Testament witnessing

The narrative of the book of Acts indicates that everywhere the early Christians travelled they witnessed to the claims of christ. As they pursued their trades and occupations, they were known as the people of God. They were the laos. In order to effectively serve the body of christ and fulfill the mission of christ, each individual was to take personal inventory and discover his/her gifts and abilities that were to be used for the upbuilding of the body, for the outreach of the gospel, and for the glory of God. Thus, New Testament witnessing was to be a spontaneous activity of the body, controlled by the Spirit of God, with each member knowledgeable of his/her gift(s) and using it/them for the extension of God's kingdom.

\footnotetext{
${ }^{1} \operatorname{Col} 4: 17$.

${ }^{2}$ Francis 0 . Ayers, The Ministry of the Laity (Philadelphia, PA: Westminster Press, 1962), 28, 29.
} 
The Greek word katartizo used in Mark 1:19 for mending nets is translated 'equipping' in Ephesians 4:12: each body member is to participate in helping other body members be repaired for service. In Galations 6:1, the 'spiritual ones' are again described as mending other body parts that are damaged, restoring them for ministry.

The New Testament picture of the body interacting together is an illustration of the intimacy experienced by the various members. Each member is dependent upon the other. Each is united into a whole. There is a oneness of mind and feeling.

Method of working

An unknown author was quoted as making a statement to the effect that "to be on the cutting edge of life, self must be immersed in the furrow of human need."2 Jesus ministered on the cutting edge of life. "From His earliest years He (Christ) was possessed with one purpose; He lived to bless others."3 What Jesus modeled through His life was imitated by His followers. The early church in Jerusalem "had all things common; And sold their possessions and goods, and parted them to all men, as every man had need."4 Help was made available to

${ }^{1}$ Ralph W. Neighbor, Jr., Where Do We Go from Here? (Houston, TX: Touch Publications, 1990), 41.

${ }^{2}$ Quoted in a sermon preached by Dwight Nelson at the Pioneer Memorial Church, Berrien Springs, MI, september $30,1989$.

\footnotetext{
${ }^{3}$ White, Desire of Ages, 70 .

${ }^{4}$ Acts $2: 44,45$.
} 
those in genuine need. When the Jerusalem church was in need, "the disciples, every man according to his ability, determined to send relief unto the brethren which dwelt in Judea." 1

Jesus lived what He taught. Thus, He inspired His followers to do the same. That is why His method of training was so effective. It was not a lifeless theory that drew men to Him. No demonstrations of blasting men with His divine power were needed. He said, "And I, if I be lifted up from the earth, will draw all men unto me."2 The fact that He gave everything for the salvation of the world is what draws all in heaven and on earth to Jesus. It can be stated no better than He Himself said it: "Greater love hath no man than this, that a man lay down his life for his friends." 3 His amazing grace, His forgiving spirit, and His self-sacrificing love is what has compelled sinners through the centuries to come to Him.

\section{World Church Education and Training}

within Adventism an urgency to discover anew the spontaneous method of Jesus in meeting human need has been widely sensed. Ellen $G$. White was the foremost member pressing forward this necessity.

\footnotetext{
${ }^{1}$ Acts $11: 29$.

2John 12: 32 .

${ }^{3}$ John 15:13.
} 
The world needs today what it needed nineteen hundred years ago--a revelation of Christ. A great work of reform is demanded, and it is only through the grace of Christ that the work of restoration, physical, mental, and spiritual can be accomplished.

Christ's method alone will give true success in reaching people. The Saviour mingled with men as one who desired their good. He showed His sympathy for them, ministered to their needs, and won their confidence. Then He bade them, 'Follow Me.'1

In an endeavor to follow Christ's method, the SDA church has carried forward a holistic ministry which offers full gospel coverage. Through formal world-wide training institutions, workers have been prepared to serve the ever growing needs of the church. ${ }^{2}$

When the SDA church came to Africa in the nineteenth century through its missionary enterprises, a consuming cross-cultural effort to propagate the gospel of Jesus Christ began. To accomplish the task effectively, sacrificial efforts were made to establish publishing houses, book centers, health care facilities, schools, and social welfare programs. With assets running into the millions of dollars, the SDA church has

\footnotetext{
${ }^{1}$ Ellen G. White, The Ministry of Healing (Mountain View, CA: Pacific Press Publishing Association, 1942), 143 .

${ }^{2}$ statistics indicate that there were 793,481 students enrolled in 5,322 schools operated by the SDA church world-wide in 1987. Primary schools numbered 4,583; secondary schools, 655; and colleges and universities, 84. Seventh-day Adventist Yearbook, 4. See table 3 in Appendix $G$.
} 
obviously established an impressive presence on the continent of Africa.

Needs assessments have been done at many local church levels in an attempt to clearly and accurately identify local needs. Steps have been taken by caring members to creatively formulate and implement possible solutions.

Doors of opportunity have opened to the church as members and leaders have united their energies together. In addition, as their hearts have been opened to God in prayer requesting that He would make them sufficient to accomplish the Gospel Commission, evidences of $\mathrm{His}$ manifold blessings have been experienced.

\section{Adventist Training of the}

\section{Ministry}

The primary functions of the pastor are to preach the Word of God and to train the laity to enter into the work of christ in seeking to save the lost. Various Adventist seminaries around the world are effectively preparing pastors to do that very work. All training of pastors is to be toward that end.

The spiritual gift of a pastor is one of an equipping ministry according to Eph $4: 11,12$. The pastor is to provide training opportunities that will enable members to use their gifts and skills effectively. However, if pastors have not received such opportunities 
themselves, they are hardly in a position to train others. In Rwanda, unfortunately, the training part has become the weak link in the chain of pastoral function.

Several years ago the pastors in Rwanda were asked to list, in order of priority, the ten most important functions of ministry they performed. The training of laymen did not appear on their list. It was not perceived to be a significant pastoral function.'

A survey of American pastors revealed that the pressing needs of the church caused the neglect of their training responsibilities. ${ }^{2}$ The very task that God designs to relieve the pastor of the many duties that occupy his time and for which he is often not qualified to effectively handle, is the one that is set aside.

While in Rwanda the training function is not perceived, in America other pressing needs take precedence over the training function. A Biblical standard for success in pastoral ministry is set forth in the parable of the talents. ${ }^{3}$ In the parable the master gives various possessions to his servants. As faithful stewards they were expected to protect and invest their

${ }^{1}$ Survey done by Phil Follett during a workers' meeting held in Kigali, Rwanda, in 1988.

${ }^{2}$ Gottfried Oosterwal, Patterns of SDA Church Growth in America (Berrien Springs, MI: Andrews University Press, 1976), 67.

${ }^{3}$ Matt 25:14-30. 
master's money. Though the resources varied among the servants, all were expected to invest what they had received.

Each pastor is given varying resources. People are the most valued resource to the church. "The talents that Christ entrusts to $\mathrm{His}$ church represent especially the gifts and blessings imparted by the Holy spirit."1 The admonition of scripture to the pastor is to "Feed the flock of God which is among you."2 As a shepherd, the pastor is required to feed and care for the essential needs of the flock. He is to fulfill his responsibility to the flock. ${ }^{3}$ The objective of the pastor should be to guide the members of the flock to use their talents to the best of their various abilities.

The special gifts of the spirit are not the only talents represented in the parable. It includes all gifts and endowments, whether original or acquired, natural or spiritual. All are to be employed in Christ's service.4

Training the lay people in service for Christ is to be the pastor's priority. He is the key person to the church's health and growth. In order for him to train others, he must first be trained himself.

${ }^{1}$ Ellen G. White, Christ's object Lessons (Washington, DC: Review and Herald Publishing Association, 1941), 327 .

${ }^{2} 1$ Pet $5: 2$

${ }^{3} 1$ Pet $5: 3$.

${ }^{4}$ White, Christ's Object Lessons, 328. 
Practical Implementations

in Rwanda

The proposed TEE program would be a distinctive approach to developing the potential of leaders who do not have access to a residence program, so that the best interests of the church can be served. God, in a sense, has an investment in each person for which He is seeking maximum interest. Ways and means are to be devised in order to train each leader to a higher level of proficiency. The practical result will be that many more people will become primary agents of ministry. The desired objective is a cooperative effort on the part of every member of the body to fulfill the Gospel Commission.

Ellen G. White's instruction to each member of Christ's body states that

The Lord desires us to obtain all the education possible, with the object in view of imparting our knowledge to others. None can know where or how they may be called to labor or to speak for God. Our heavenly Father alone sees what He can make of men. There are before us possibilities which our feeble faith does not discern. our minds should be so trained that if necessary we can present the truths of $\mathrm{His}$ word before the highest earthly authorities in such a way as to glorify His name. We should not let slip even one opportunity to qualifying ourselves intellectually to work for God. ${ }^{1}$

In the parable of the talents, those buried and unused were lost. Conversely, those talents that were used were multiplied. Greater gifts came as a result of

${ }^{1}$ Ibid., 333,334 . 
the wise investment of the talents bestowed by the Master.

Many of the laity of the church in Rwanda are eager to be equipped to meet the final pending issues of the great controversy between truth and error. When they see their ministers' hearts all aglow with love and zeal for the truth, and with a desire to save souls, the churches will arouse themselves. These generally have the gifts and power within themselves to bless and strengthen themselves, and to gather the sheep and lambs into the fold. They need to be thrown upon their own resources, that all the gifts that are lying dormant may thus be called into active service. ${ }^{1}$

It is anticipated that the proposed TEE program would activate the dormant gifts of laity and workers. A large percentage of the church's members have latent abilities that have not been developed for the service of the church. Pastors are not training the willing workers in their congregations. TEE would focus on developing qualified leaders, who in turn would work to develop all the potential of the local congregations, so that the mission of the church could best be served.

\section{Limitations of the} current situation

A subsistence economy means that priority is given to food production to feed the growing population. Families are preoccupied with the task of providing

${ }^{1}$ Ellen G. White, Testimonies for the church, 9 vols. (Mountain View, $C A$ : Pacific Press Publishing Association, 1948), 3:204, 205. 
sufficient food for their own needs. Rural families simply have no cash.

Funds available for educational purposes are extremely scarce. Only a select few persons are able to obtain bursaries for university-level study. By the time parents sacrifice to put their children through primary school, and a few through secondary school, there are no resources available for parents to consider continuing education themselves.

None of the administrative units of the SDA church in Rwanda are presently self-supporting. Subsidies are received through appropriations from the higher organizations for operational needs. Only token amounts are given in appropriations for scholarship bursaries. Neither the church member nor the local churches are in a position to fund training for the numbers of people needing training. The church simply cannot pay the costs for large numbers of tertiary trained leaders. 1

It is anticipated that TEE would (1) make available a cost-effective method of providing leader training without incurring high tuition and boarding expenses, prepare a cadre of self-supporting leaders to serve the interests of the local churches, (3) enable candidates to needs.

${ }^{1}$ See Appendix D for the projected ten-year pastor 
study while they continue to provide for the needs of their own families, (4) require the candidates to carry responsible leadership posts in their churches, and (5) insure that what the candidates learn is put to use immediately in their contextual situation.

\section{The Need for a solution}

The fulfillment of the Gospel Commission confronts the Christian world with an awesome challenge. Seventh-day Adventists have long believed that when the "gospel of the kingdom shall be preached in all the world for a witness unto all nations,"1 the end will come. In consequence of this belief, large investments of human and material resources toward the fulfillment of this objective have been made. Yet, while the world population is increasing by 238,000 per day, Adventist church growth is less than 2,000 per day. ${ }^{2}$

In an effort to address seriously the mandate of the Gospel Commission, in the fall of 1986, the former president of the General Conference of Seventh-day Adventists, Neal C. Wilson, called for the development of a global strategy of mission outreach for the Adventist Church. He said, "I believe this church has the human

${ }^{1}$ Matt $24: 14$.

${ }^{2}$ Humberto M. Rasi and Charles R. Taylor, "Adventist Global Strategy," Dialogue, vol. 1, no. 2, 1989,5 . 
and financial resources to finish the work. . . It may take some redeployment, redirection, but we are capable of completing the task."1

A new strategy for Africa was envisioned in the global strategy concept. By the year 2000 Adventist membership in Africa is predicted to reach five million. ${ }^{2}$ In order to properly prepare for this growth, a number of objectives were called for in the strategy: (1) educating and training indigenous ministers, (2) extensive training for lay pastors, (3) organizing and staffing new secondary schools, (4) building new churches, (5) entering unreached territories, (6) converting to self-help, (7) redirecting finances from areas of large Adventist populations, and (8) reducing the level of expatriate workers. ${ }^{3}$

More recent plans call for planting a SDA church in each population segment of one million or more where presently there is no SDA church. There are nearly 1800 such segments. ${ }^{4}$ The strategy envisions a new church begun

\footnotetext{
'Carlos Medley, "Newsbreak," Adventist Review, 30 October 1986,8 .

${ }^{2}$ Ibid., 12 .

${ }^{3}$ Ibid. , 12-13.

${ }^{4} \mathrm{~J}$. David Newman, "Global Strategy Shifts Church's Goal," Ministry, June 1989, 18.
} 
begun every other day for the next ten years. ${ }^{1}$

Though the church in Rwanda has no large people groups that have been untouched by the Gospel, it is faced with the challenges which accompany rapid membership growth. It has been stated that "the greatest opportunity facing the churches as they carry out that most central of all their missions is 'The Discipling of the Nations." "2 Though the task is mammoth, it is not impossible. An African proverb says, "You can eat an elephant if you do it one bite at a time." ${ }^{3}$ The proposed TEE program will help reduce the task to bite-sized pieces.

Current statistics and trends make theological education in context a top priority. The TEE movement "has come on the horizon at this particular moment of history as an alternative model to the traditional schools of the past 150 years."4 No longer can an elitist group be trained to care for the new members coming into the Adventist Church in Rwanda. TEE would help to reverse the elitist tendency of the ministry.

\footnotetext{
${ }^{1}$ Floyd Bresee, "Annual Council Report," Ministry, December $1989,21$.
}

2Donald McGavran, The Church in a Revolutionary Age (st. Louis, MO: Christian Board of Publication, 1955)， 7 .

${ }^{3}$ Hogarth, 151.

${ }^{4}$ Kinsler, "Extension: An Alternative Model for Theological Education." in Learning in context, 28 . 


\section{Towards an Indigenous \\ Model of Ministry}

The words of Jesus Himself provide the principle directive for an indigenous ministry. Jesus used Jewish parables and catagories of thought to reach the Hebrew mind. At the outset of His ministry Jesus went into the synagogue, stood up, and read from Isa 61:

The Spirit of the Lord is upon me, because he hath anointed me to preach the gospel to the poor; he hath sent me to heal the brokenhearted, to preach deliverance to the captives, and recovering of sight to the blind, to set at liberty them that are bruised, to preach the acceptable year of the Lord. ${ }^{1}$

Jesus clearly understood His mission to be one of servanthood in a cultural context. His training of the disciples brought this concept into clear focus.

Ye know that they which are accounted to rule over the Gentiles exercise lordship over them; and their great ones exercise authority upon them.

But so shall it not be among you: but whosoever will be great among you, shall be your minister:

And whosover of you will be the chiefest, shall be servant of all.

For even the Son of man came not to be ministered unto, but to minister, and to give his life a ransom for many. ${ }^{2}$

Just as soon as the woman of Samaria had an encounter with Jesus at Jacob's well (John 4), she became the instrument to bring the "Good News" about Jesus to her own people. Her witness aided her people in having a similar personal experience as she brought them to Jesus.

\footnotetext{
${ }^{1}$ Luke $4: 18,19$.

${ }^{2}$ Mark 10:42-45.
} 
The training of servant leaders who will bring their family and friends to Jesus, who are firmly grounded in Bible truth, and who will work to plant new congregations, is the desperate need of the Adventist church in Rwanda today. The proposed TEE program offers new possibilities for effective training in ministry to the members within the churches of Rwanda who have been excluded on account of the lack of entry equivalency, age, language, sex, race, family considerations, etc.

\section{Indigenization}

There has been a noticeable development in the inculturation movement that is evident by the passage from one set of terms to another. "Adaptation is the term that has been used for a long time to signify . . . the reality of an indissoluble marriage between Christianity and each local culture."I Accommodation is the term that has been used to connote attempts of christianity to adapt to the local context. Two types are prominent.

They are 'apostolic accommodation' and 'prophetic accommodation'. The first describes the work of taking the apostolic or biblical faith and accommodating it to the people of a respondent culture by the processes of translation, adaption, interpretation and application, so that as much as possible of its original meaning and relevance will be preserved. The second describes the work

${ }^{1} \mathrm{~J}$. M. Waliggo and others, Inculturation: Its Meaning and Urgency (Nairobi, Kenya: St. Paul Publications, 1986), 11. 
of 'entering a culture context discerning what God is doing and saying in that context, and speaking and working for needed change.'i

Indigenization added a new dimension. It referred to the same process but highlighted the necessity of promoting indigenous church ministers in every locality. other terms have followed: reformulation (putting Christian doctrine in the thought and language that is understood by contemporary people), incarnation (referring to the act of christ becoming man in order to save humanity), and inculturation (underlining the importance of cultures as the means of realizing the incarnation process of Christianity). Each of these terms has primarily amplified the basic meaning of indigenization.

Indigenization is the attempt to locate, in the country being evangelized, words, concepts, art forms, social groupings or psychological characteristics which can: (1) become communicative links from the Gospel to the people; (2) enable the church and its life to appropriate those cultural elements compatible with the Gospel, to minimize the shock of transition from the old to the new community; (3) help to determine what a new and genuinely Christian culture would be in that country. The problem of indigenization, then, is three-fold. It involves communication, adaptation and cultural synthesis. ${ }^{2}$

The process of indigenization seeks to insure the permanence of Christianity in each culture. It is the process by which Rwandans make Christian ideas part of

${ }^{1}$ Hogarth, 56.

${ }^{2}$ Vern Rossman, "The Breaking in of the Future: The Problem of Indigenization and Cultural Synthesis." International Review of Mission, 52 (1963): 130. 
their own thinking, regardless of whether they feel that the Christian vision of life fulfills their own needs or regardless of whether the Christian world view has actually become part of their aspirations.

\section{Contextualization}

At the 1974 Lausanne Congress on World Evangelization held in Lausanne, Switzerland, contextualization was defined to mean:

the translation of the unchanging content of the Gospel of the kingdom into verbal form meaningful to people in their separate cultures and within their particular situations.'

The concern of contextualization is how to make sense of the Christian message in the local context. "A church only grows spiritually if its members learn to apply the teachings of the gospel to their own lives."2 Contextualization means taking a critical look at old beliefs, rituals, stories, songs, customs, art, music, etc., and coming to understand the meaning and place they occupy within their cultural setting. The beliefs and customs are neither accepted nor rejected without critical examination. "They are first studied with regard to the meanings and places they have within their

\section{${ }^{1}$ Hogarth, 47 .}

${ }^{2}$ Paul G. Hiebert, Anthropological Insights for Missionaries (Grand Rapids, MI: Baker Book House, 1985), 185. 
cultural setting and then evaluated in the light of biblical norms."l

Several considerations are necessary for the process of contextualization to take place. First, there must be a recognition among the concerned individuals "to deal biblically with all areas of life."2 Next, missionaries and local church leaders must take the initiative to lead the targeted individuals to gather and analyze the traditional customs. Then the leaders must lead the targeted audience in a Bible study related to the questions under consideration. People must be led to analyze their way of life in the light of biblical teachings.

The process of contextualization creates both negative and positive reverberations. Balance, timing, and discretion must be carefully considered in contextualization. For instance, in the Islamic areas, contextualization of lifestyle must be in harmony with local norms, expectations, and preferences. Some new missionaries have adopted local Muslim dress and lived in very simple homes surrounded by Muslims. While some of the neighbors have accepted them as part of their community, others have viewed the Westerners as somewhat odd. "They could not understand why Americans would

\footnotetext{
${ }^{1}$ Ibid. , 186 .

${ }^{2}$ Ibid.
} 
deprive themselves in such an extreme manner." I At the same time, seasoned missionaries living on a nearby compound became critical of the new arrivals. They resented that they were "going national" and regarded them as extremists.

Some Christians have vehemently opposed the use of the word "Allah" as the word for God. Yet, historically the Arabs used that word in pre-Muhammad times for God. Arab Christians used the same term as a biblical word in the centuries before Islam. ${ }^{2}$ Words have great power. Use of the word "crusade" by the Christian in speaking of an evangelistic meeting brings forth a negative image in the mind of the Muslim.

In Muslim work, the strategy is often to initiate some type of assistance ministry. Physical and spiritual needs are both ministered to through this endeavor. With some Muslims the response to the assistance programs is very positive, while with others there is suspicion. They may see "ministries such as hospitals, schools, orphanages, self-help programs and agricultural projects as blatant, immoral, unethical inducements toward proselytization." 3

'J. Dudley Woodberry, ed., Muslims and Christians on the Emmaus Road (Pasadena, CA: Zwemer Institute of Muslim Studies, 1989), 257.

$$
\begin{aligned}
& { }^{2} \text { Ibid., } 254 . \\
& { }^{3} \text { Ibid., } 258 .
\end{aligned}
$$


The methodology of contextualization is not as important as our spiritual relationship with our Lord.

When the devout Muslim asks us if we pray five times a day, do we have an answer of spiritual equivalence? Are we somewhat embarrassed when requested to share details of our fasting belief and practice? Do we treat our Bible with the same respect the Muslim does his Quran? In sensitivity to the Muslim, can we assure him we do not eat pork or drink alcoholic beverages?

Perhaps we need to ponder deeply what it means to be 'all things to all men' as we confront the issue of incarnated spirituality. Whatever else it means, the bottom line is that Muslims must experience Jesus when they experience us! ${ }^{1}$

The aim of contextualization is to make the gospel meaningful and relevant. The proposed TEE program would contextualize learning. Training would be geared to the life situation of the students. There is a tendency for traditional teaching programs to be strictly academic in orientation. Self-instruction materials utilized in TEE are designed (1) to help the student to minister more effectively, (2) to provide lessons which are more practical than theoretical, and (3) to benefit the student in his actual ministerial context with lessons aimed at enabling him in his ministry. The writers of the programmed learning texts have very carefully considered the educational levels of the students being targeted. Input was received from the nationals themselves concerning which subjects were most needed. Problems also were addressed based upon the

$$
\text { IIbid., } 263 .
$$


perceived need as viewed by the local leaders.

Course formats have been motivating and

encouraging to the men and women receiving training

because they have not been too demanding. Texts have been prepared in manageable units which enable the

students to assess their own progress. Answers have been included in the text so that the student receives immediate confirmation and correction. The amount of study and the level of difficulty have been tailored to the local situation. The practical orientation of the texts has also been noted as one of the salient strongpoints of TEE.

Contextualization of education is not just western forms, curriculum, etc., but it is rooted in the social-economic situation of the people, using the actual forms, patterns of thinking, and communication of the local group, a hierarchy, or priority of values, is shaped by the local setting.

\section{A More Suitable Alternative}

Rwandan pastors and church leaders want and need certificates, credits, degrees, and diplomas. The level of general education in the local society is increasing rapidly. If the local pastor is to maintain the respect of his congregation, he must be able to challenge and stimulate the thinking of his members in theological areas. In a similar manner, local church leaders working 
under the local pastors of five to thirty church

districts must receive suitable training to enable them

to be credible leaders of the churches they shepherd.

\section{Philosophy of Approach}

A TEE strategy for Rwanda would seek to fulfill

the following conclusions of Mulholland:

1. Theological education by extension takes into account the varied forms of ministry inherent in such historic patterns of training as apprenticeship, in service training, and tent-making ministry, instead of trying to force all candidates into the mold of fulltime, urban oriented, professional scholarpastor.

2. It allows a single school to work on more than one academic level and in more than one cultural sphere. It reaches out to the real pastoral leadership of the church with first-rate theological education, allowing these men with high potential to become more than second-rate leaders.

3. It simplifies the structure and lowers the cost of theological education by adapting not only to the socio-economic conditions, but also to the cultural and educational patterns of the developing nations.

4. It incorporates modern educational principles, such as the 'split rail fence' model, contextualization, and program learning into its educational theory. Learning takes place in the context of daily life. Thus it gives promise to being able to train students to depend upon their own God-given resources for continuous, lifetime study.1

There are six basic ways in which the above four conclusions would be implemented:

1. Geographical extension. The Kigali Training Center as an institution would become the headquarters

${ }^{1}$ Kenneth B. Mulholland, Adventures in Training the Ministry (Nutley, N.J.: Presbyterian and Reformed Publishing Co., 1976), 207-208. 
for the TEE project and would coordinate its operation. It would be responsible for seeking out those students who may not be able to leave their work to come to the Training Center.

2. Extension in time. The TEE program would seek to fit the schedules of the students by taking into consideration the most convenient time to hold classes.

3. Cross-cultural accommodation. The TEE program would endeavor to contextualize in its approach to the culture of the people needing training by making the teaching relevant to the culture in which the learners have been called to minister. TEE would enable students to take theological training while continuing to live within their culture.

4. Academic flexibility. TEE would emphasize flexibility by seeking to accommodate persons of varying academic qualifications and to help them develop from where they are, rather than demand that they achieve a certain academic level before they can benefit from theological education.

5. Economic conservation. There would be a possibility of reducing the high cost of theological education now being provided at AUCA. Taking TEE to the people has been found in other programs to be much cheaper than bringing people to the residence seminary. TEE would contextualize costs. 
6. Ecclesiastically focused training. TEE would have a better chance of being "church-centered" than the residence seminary program in that it would be done within the confines of the local church.1

The above aims for a new style of ministerial training would not only strengthen the grass-roots leaders at the local church level, but would also at the same time strengthen the residence program at AUCA since some students beginning in the extension program could possibly transfer into the residence program. The greater support for AUCA, however, would come from a positive attitude of TEE students toward the training objectives of the university program. It is hoped that those having benefitted from TEE training would be much more supportive of the advanced training offered at the university.

The new form of education would help each candidate to be trained to identify church needs and to develop solutions to satisfy those needs. Emphasis would be given to practical skills. TEE graduates would be equipped to communicate the gospel effectively. The flexibility of the TEE program would be its strength.

${ }^{1}$ Baraka G. Muganda, "Planning a Needs-AssessmentBased Approach to Continuing Education Programs for Seventh-day Adventist Clergy in the East Africa Division" (Ed.D. diss., Andrews University, 1983), 45-46. 
Young and old, workers and laymen alike, would be helped bY TEE.

\section{Curriculum Planning}

The cultural context has been taken into consideration in the prepared Programmed Learning Texts that would be used. The proposed program would use texts that are already prepared and available in the local language. Where texts are not currently available, translation of relevant materials to be used by the instructors could be done at the RUM headquarters. A philosopher has once observed that "The source of knowledge is not in books, it is in reality and in our thoughts. Books are signposts." 1

Current texts have been prepared in and for East Africa so that they are culturally suitable. ${ }^{2}$ The firsttier curricula would utilize these already prepared texts and would require very little adaptation. These books are the signposts referred to above. Their one main function is to show the way to those in search of direction. Though the evangelical texts may not meet our requirements in every detail, it would not be practical to wait until SDA texts have been prepared. These texts

${ }^{1}$ R. J. Njoroge and G. A. Bennaars, Philosophy and Education in Africa (Nairobi, Kenya: General Printers, 1990), 251.

${ }^{2}$ See examples of lessons in Appendix L. 
primarily have to do with biblical and pastoral concerns. Doctrinal and general subjects would have supplied materials in hand-out format similar to the prepared texts. The long-range goal would be, however, to have all courses in the Programmed Learning format designed to fit precisely the local church and cultural context.

\section{Staffing Considerations}

Provision would be made for specialized training to prepare those who would carry the facilitator roles. These persons would be nationals currently employed at a national wage rate. Those who facilitate the learning process through TEE should be appointed on the basis of merit. "You can no more elect men to these specialized positions by popular vote than you could the head surgeon of a hospital."1 Teachers with the biblical gift of teaching would be selected. Lecturing as is done in the traditional classroom setting would, however, be avoided. Instead, personal interaction to encourage learning would be the approach.

\section{Location Rationale}

TEE is a program of theological education that is "in contrast to the traditional method of study where the student goes to the school, in TEE the school comes to

${ }^{1}$ George Patterson, Church Planting through obedience oriented Teaching (Pasadena, CA: William Carey Library, 1981), 44 . 
the student." ${ }^{1}$ The teacher actually goes to a location near the student once a week. In this way theological education is made available to the student in the place where he lives and works. It is not necessary for the student to go away to study.

Most extension programs in Africa, and in other parts of the world, initially have been extensions of seminary residence programs. Even their curriculum, content, requirements, and credits have followed closely the same school year as residence classes. However, the traditional seminary course is geared for young, unmarried, inexperienced candidates, whereas the typical TEE student is older, married, and with a family, having had experience in secular and church work. The TEE program was prepared to meet the specific needs of the more mature church worker.

The uniqueness of the extension program is that the learning experiences take place away from the campus. Classes are less frequent and study is done at home. Weekly meetings require minimal travel for the student. "The extension center is simply the place where the extension classes meet. It might be a church, a school, a rented room somewhere. But wherever it is, it

\footnotetext{
${ }^{1}$ W. Frederic Sprunger, TEE in Japan (Pasadena, CA: william Carey Library, 1981), 124 .
} 


\section{7}

represents the school."l The size of the program determines the number of centers needed to accommodate the students. Centers are located in the most convenient place for the majority of the students.

\section{Method of Learning}

As has been mentioned, the primary method of teaching would not be through lecturing. Only critical issues would be presented in that format. The teacher monitors the students progress. He checks that assignments are done. He answers questions that the student may have and encourages the student in his independent study. Most of the learning takes place at home. Knowing that the teacher will be checking the assignments inspires an inbuilt accountability. A different type of dynamic is experienced in TEE programs as opposed to the residence programs. Students seek to make the best of the time they have with the teacher. Attendance is an important part of the student's grade. His daily work, exam scores, attendance, participation, and application of material all factor into the student's final grade.

\section{Implementation of TEE}

The initial steps towards implementation of a TEE program in Rwanda would require dialogue, consultation,

I'Ibid., 135. 
and negotiation among the key leaders of the RUM. The concept would need to be studied. The leaders would need to be inspired with the possibilities after they were acquainted with its background and goals.

Next a TEE committee would need to be appointed. The committee would be delegated the responsibility to develop the program. Authority would be given to make and oversee decisions on appointment of personnel, goals, curriculum, text usage and preparation, and over all details within accepted budget and policy. A director to coordinate and administer the program would need to be appointed to carry out the decisions of the TEE committee.

TEE would easily fit within the existing organizational structure of the church. It would function directly under the Ministerial Department in cooperation with the Education Department on each organizational level. 


\section{CHAPTER IV}

\section{HISTORY OF TEE}

\section{origin in Central America}

TEE first came into use in 1963 in Central

America. Rural students would not come to the capital city for training. Those that did come wanted to pastor in the urban centers. Faced with a problem of training leaders for the rural churches of Guatemala, the Presbyterian Seminary decided to initiate a new program which was essentially a decentralization of the seminary. The extension program did not replace the residential program, but became an extension of the seminary. Local centers were established in church buildings with a small library in each. A professor would go and teach at each center once a week. Half of the teachers were nationals and half were missionaries.

Two days a month, all students of both extension and resident programs came together at the seminary for a monthly meeting. The monthly meeting was for lectures, exams, and social interaction. Travel expenses were cared for by the seminary. Books and a small tuition fee were the student's expenses. Completion of course work 
for the full-time residents normally took three years. Extension students might take as long as fifteen years to complete the same course of study. Special class schedules were planned to accommodate the TEE students. Evenings, weekends, vacations, and holidays were used as needed. Immediately, TEE "enrollment jumped from 5 to 50 in 1963, 88 in 1964, 90 in 1965, and 143 in 1966."1

Self-study text books were finally developed because of difficulty experienced in getting extension students to do their one-hour-a-day study required for each course. Traditional textbooks were difficult for extension use with the limited teacher-student contact. In addition, it became impossible to teach everyone at the same level. Entrance required sixth-grade proficiency but allowed for a great margin of diversity among students. This problem necessitated the establishing of four levels of achievement. Upgrading was possible when requirements had been achieved for each level.

A number of discoveries surfaced from the extension program:

1. Students and faculty they had never noticed before popped out of nowhere.

2. They were able to reach higher as well as lower academic levels than before.

3. They could train men right where they were, in their own environment.

\footnotetext{
${ }^{1}$ Winter, 460, 461.
} 
4. Extension studies gathered men who had both talent and personal discipline.

5. There were more young men than ever, despite a higher average age.

6. The curriculum was the same, but the new students did better work.

7. The program cost far less per student.

8. With no increase in personnel or funds, enrollment increased from 7 to 200 .

9. Extension studies can also handle students not studying for ordination.

10. Extension studies take longer, but keep a man studying seriously.

11. Students can teach laymen, and potentially reach any laymen in the church.

12. There is the possibility of sharing weekly meetings with other denominations.

\section{Developments in TEE}

The original purpose of TEE was to train mature leaders for ministry "in the growing but scattered Presbyterian congregations of Guatemala."2 clearly the most rapid growth of TEE has been experienced in the Latin American and Caribbean countries. "Most of the major residential institutions have developed extension programs of their own, and several associations have been formed to provide direction, resources, and training." 3

$$
\text { Within a period of about ten years (1963-1973), }
$$

the TEE movement mushroomed to encompass more than sixteen thousand students in nearly 200 institutions in

${ }^{1}$ sprunger, 128 .

${ }^{2}$ Kinsler, Ministry by the People, 38 .

${ }^{3}$ Harley Atkinson, "Theological Education by Extension: An Alternative in Education, " Christian Education Journal 10, (1990) 2:33. 
fifty-seven countries. ${ }^{1}$ By the early 1980 s there were one hundred TEE programs in twenty-three countries of Africa alone." "Like the Latin American countries, the nations of Africa are seeing a tremendous movement towards Christianity, so much so that they are having trouble training and providing adequate leadership." 3 Response to TEE in Africa has been so favorable that it is now second to Latin America in developing TEE programs. ${ }^{4}$

TEE in India

Taking the basic extension concept of TEE as a model, Dr. Ronald Seaton and his wife Edith developed a wholistic approach to health education by extension in Western India. For over a decade they worked to provide comprehensive health service to the people of India. Using members of the mission hospital staff as trainers, they worked to develop a cost-effective program of continuous training of community health workers that enabled volunteers to bring health to their own communities. Medical institutions were thus aided in their mission of reaching out into their communities with

\footnotetext{
${ }^{1}$ Mulholland, 77 .

${ }^{2}$ Hogarth, 164 .

${ }^{3}$ Atkinson, 33 .

${ }^{4}$ Ibid.
} 
a unique emphasis on health and wholeness. Through the observation of health services in the United States, India, China, Africa, Central America, and the Far East, the seatons were stimulated to pioneer a healtheducation-by-extension program suitable for general application. ${ }^{1}$

Mennonite Initiative

TEE work by the Mennonites began in Taiwan in the fall of 1971 with a total of twenty students. Within a period of three years, classes increased from three to eighteen, while enrollment increased from 20 to about $180 .^{2}$ Workshops were conducted in various locations to create interest in the extension concept. ${ }^{3}$

\section{Honduras Dimension}

In Honduras another dimension was added to TEE by George Patterson. He stressed the virtues of Theological Education and Evangelism by Extension (TEEE). Through the Honduras Extension Bible Institute, Patterson has developed a specific orientation known as

'Ronald S. Seaton, M.D. and Edith B. Seaton, Here's How: Health Education by Extension (Pasadena, CA: William Carey Library, 1976), xii.

\footnotetext{
${ }^{2}$ Sprunger, 150 .

${ }^{3}$ Ibid., 151 .
} 
Obedience-Oriented Education. ${ }^{1}$ His emphasis is on a way of thinking and acting that is in absolute obedience to Christ. It denounces education that results in passive learning. Instead, strong emphasis is given to the Biblical principle: "Be ye doers of the word and not hearers only, deceiving your own selves" (Jas 1:22).2

\section{TEE in North Sumatra}

The primary objective in North Sumatra was to design an educational upgrading program for about 900 pastors and 4,000 elders. Few of the leaders had formal education to prepare them for the work they were doing in the churches. They had been given their work responsibilities because they were capable persons.

since the lay leaders all had full-time work in addition to their church responsibilities, it was important to develop a curriculum that would accommodate their schedules. Two denominations, the Christian Church of Indonesia and the simalungun Protestant Christian Church, decided to work together to develop a relevant curriculum. They began by researching problems actually experienced by their leaders. Problems of the society served by their pastors were identified. By receiving input from those who would directly benefit, it was

${ }^{1}$ George Patterson, obedience-oriented Education (Alta Loma, CA: Community Baptist Church, n.d.), 1. 
discovered that much of the available material dealt with problems relevant to European situations and had little to do with issues challenging the church in North Sumatra.

Church officials worked closely with the pastors to prepare courses designed to help them achieve what they felt were important goals.

We also discovered the importance of training Indonesians to prepare the course materials. Too often the tendency has been to supply missionaries as writers or to translate materials prepared in other regions of the world. From our experience we found that the period of four years it took to prepare people to write was well worth it. We have been able to develop a more effective training programme and now need only two years to bring people to this point. ${ }^{1}$

Courses for the pastors began in the early part of 1981. Pastors then became facilitators in the training of their lay leaders.

\section{Extension in the USA}

Today the extension program is no longer limited to the Third World countries where it was born and nurtured. Varied programs have been successfully implemented in the United States. Though they differ from those in the developing world where programmed instructional materials are used, they emphasize study at home and have the goal of producing Christian leaders through programs of training other than the traditional 
residence programs. Hence, they qualify to fit the extension category. ${ }^{1}$

\section{Philosophy of TEE}

TEE did not arise from a carefully conceived philosophical base, but instead originated as a response to a need. "It is said that 'Necessity is the mother of invention,' and in this case, it was certainly true." ${ }^{2}$

Certain presuppositions have formed the undergirding of TEE even though its development came about as a practical response to a pressing need. First, there was the conviction that churches had a need for adequate leadership. Next, there was a recognition that training needed to be given to those leaders who were gifted but untrained. Then there was a recognition that extension would need to be the method in order to accommodate those who would be the recipients of the training.

TEE did not arise because there was a feeling that other programs in theological education failed and should summarily be laid to rest.

Situations differ from country to country and from one time to another. Very likely there are situations due to geography, political climate, cultural view and academic level of students which

\footnotetext{
${ }^{1}$ Wayne $c$. Weld, The World Directory of Theological Education by Extension (Pasadena, CA: William Carey Library, 1973), 308 .

${ }^{2}$ Sprunger, 129 .
} 
would call for a different approach to theological education. ${ }^{1}$

It has been aptly stated that "Leadership needs cannot be bottlenecked in institutions. Extension meets this challenge." 2 Theorists in the field of education press for increased networks of educational facilities to provide greater access to education resources. Extension is one way to make this possible. ${ }^{3}$ Distance learning opportunities is what TEE provides.

\section{Experience in Australia}

A different type of TEE program has been developed at Alcorn College in Brisbane, Australia. The college is a leadership development center within the Uniting Church of Australia. Recognizing the need for leaders who can develop leadership in the church in general, not just among a few specialized professionals, the college developed an inductive learning approach to TEE using programmed cassettes and books to stimulate interaction and contextual learning. ${ }^{4}$

The traditional approach to teaching is through

${ }^{1}$ Crider, 6.

${ }^{2}$ Geoffrey Waugh, "Liberate Leadership: An Innovative Model of Theological Education by Extension Using Seminar Cassettes" (M.A.. thesis, Fuller Theological Seminary, 1984), x.-.

${ }^{3}$ Ibid.

${ }^{4}$ Ibid. , 10 . 
the deductive method. "There is a basic attitude that one who knows is giving to those who do not know. The teacher sees his role as an imparter of knowledge." In contrast is the inductive method of teaching. This method actually demands more of the teacher and the student.

This approach starts with the learner, with his real needs, life experiences and situations. Learning is never a detached experience. Participants become vitally involved. . . . opportunity is given to both the teacher and the group members to share in the learning process. Group learning becomes an adventure in discovery; starting with a real problem; looking deeper to find the basic issues; sharing in an effort to find guidance from printed resources and people with special knowledge; planning action on the basis of understanding gained. What has been learned becomes a part of life's experience and a basis for future action.2

The cassettes are designed to be used at the extension center meetings. A pilot group is used to record the sessions. The teacher presents the issues and then shuts off the casette during the group discussion. Then a summary of group opinions or decisions is recorded. This gives additional input to and discussion at the extension center meeting. When it is used it is also switched off after the issues are presented.

After the extension group interacts on the given subject, they listen to the pilot group interaction, then

\footnotetext{
${ }^{1}$ Ibid., 17

${ }^{2}$ Ibid., 23
} 
they interact again applying all their pooled ideas to their own context of learning and ministry. The above method enables the extension group to have the advantage of the thinking and experience of another group. The pilot group's comments are not listened to until after the extension center group has come up with its own recommendations and decisions. ${ }^{1}$ The pilot groups have been recorded on both audio and video cassettes.

\section{Experience in India}

Studies conducted in 1981 by the Conference Superintendent of the India Free Methodist Church ${ }^{2}$ indicated an 18 percent membership loss for the year. The reason given was that 65 percent of the rural churches had no pastors. Though 157 were recently baptized, there was no one to teach them the fundamental Christian doctrines. It was expected that without instruction they would soon return to their old religion. ${ }^{3}$

Half of the present pastors were expected to retire within a few years and only three students were in the seminary preparing for graduation. TEE was viewed as

\footnotetext{
${ }^{1}$ Ibid., 42.

${ }^{2}$ Hereafter IFMC.
}

${ }^{3}$ Daniel Ward, "Theological Education by Extension: A Proposal for India's Free Methodist Church" (M.A. thesis, Fuller Theological Seminary, 1982), 69. 
a means of helping in their critical situation. "In 1925 there were 150 missionaries serving in the IFMC area. Today there is only one couple. The 'missionary gaps' need to be filled by national leaders." 1 Implementation of a TEE program was viewed as essential to the ministry and mission of the IFMC.

During the 1970 s the church growth rate was nearly 33 percent per decade in comparison to the population growth rate of about 22 percent growth during the same period. ${ }^{2}$ As in many other countries it was the pressing need that made the TEE model attractive.

\section{Experience in Spain}

The Spanish Institute of Theology at a Distance is an extension program that was created in response to the second Vatican council. The need for continuing education for priests and lay leaders in Madrid inspired an ambitious venture in theological education.

The Institute has been designed to serve the working people who could not attend regular classes. Courses have been prepared so that study can be guided primarily through workbooks. The studies have been developed with doctrinal, spiritual, and pastoral dimensions in mind. Professors facilitate the learning

\footnotetext{
${ }^{1}$ Ibid., 73.

I'Ibid., 79.
} 
process through regular seminars that meet the schedules of the students. Results have been impressive:

The first academic course was inaugurated on 15 September 1973. The response was extraordinary throughout the Diocese. Soon letters from other dioceses and countries requested information and brought matriculations. By the end of 1973 there were 500 priests and 320 religious and lay persons enrolled. By the end of 1975 the total enrollment was 3,031 with 1,585 priests and 1,446 others. In 1978 the name was changed to International Institute of Theology at a Distance. In 1981 the enrollment reached 6,700, including 27 students in six countries of Asia, 44 in nine countries of Africa, 289 in eight European countries other than Spain, 15 in the US, and 2,354 in 17 countries of Latin America. ${ }^{1}$

\section{Models in Africa}

In the mid-1970s Bishop Kauma, principal of Bishop Tucker Theological College in Uganda, made the following observation: "It is more than clear that in Africa many of our theological schools are outmoded. Many are modelled on the pattern of theological colleges of the mother church."2 Then he aptly stated that "What is taught is answering questions that Africa is not asking. " 3

TEE programs have been established in Africa today in response to a need and cry for relevance. African churches and missions realized that the leaders

\footnotetext{
'Kinsler, Ministry by the People, 307.

'Ibid., 103 .

${ }^{3}$ Ibid.
} 
of their local congregations were not adequately trained. They were also aware that existing programs were not training sufficient numbers of leaders. The concern for relevance and contextualization of performance in ministry eventually led to the establishment of the Association of Evangelical Bible Institutes and Colleges in Africa and Madagascar (AEBICAM). 1 This organization has worked to broaden the concept of ministry in context, improve library facilities, and to bring relevance to curricula. "When Theological Education by Extension was introduced by the Committee to Assist Ministry Education overseas (CAMEO), ${ }^{2}$ it came first as an addition to the residential school." ${ }^{3}$

The basic Tee model used in Africa was designed for the Presbyterian Seminary of Guatemala. Through the CAMEO workshops, it was promoted worldwide. After its formation in 1966, AEBICAM became the principal moving force that promoted the expansion of TEE across Africa. ${ }^{4}$ During the first few years of its operation it concentrated on gathering theological educators together for sharing and dialogue. The discussions resulted in a growing support for TEE.

\footnotetext{
${ }^{1}$ Hereafter AEBICAM.

${ }^{2}$ Hereafter CAMEO.

${ }^{3}$ Kinsler, Ministry by the People, 105.

${ }^{4}$ Ibid. , 108
} 


\section{African Independent Churches}

An experimental TEE program was developed by Dr.

M. L. Daneel, professor of missiology at the University of South Africa, among the Shona Independent churches of Zimbabwe.

His proposals for a joint theological training center were discussed at length at the various church headquarters. Most leaders responded enthusiastically to the prospect of theological training for their leadership. They generally underscored the basic idea that they themselves should take the responsibility for such a venture, even though they were aware that financial and administrative problems were bound to arise. The ecumenical aspect of the project troubled some, especially the leaders of the spirit-type churches. ${ }^{1}$

After long discussion regarding the conditions of membership of the new association, twelve of the Independent churches in July of 1972 agreed to form the African Independent Churches Conference. The objectives included the establishment of a theological training school, a scholarship fund for worthy candidates, and promotion of interchurch relations through planned conferences. ${ }^{2}$

At the organizational meeting, preparations were also made to establish rural TEE centers. Initially three centers were opened. In 1974, two additional centers were opened. BY 1981, eighteen centers were

$$
\begin{aligned}
& \text { IIbid., } 119 . \\
& { }^{2} \text { Ibid., } 120 .
\end{aligned}
$$


operating and 600 students were being trained through the extension program. ${ }^{1}$

Its success must be seen not against any preconceived standard or idea of what a theological course should do or be but in the light of whether it is achieving its goal within its own context. If the testimony of one of the students who has become a teacher is any guide, then it is true to say the program is progressing well. He claims that for him the course has not only increased his Bible knowledge and his effectiveness as a preacher, but in addition has increased self-knowledge and understanding of weaknesses in life and ministry.

\section{TEE in Tanzania}

A TEE program was established in the Arusha area in January 1974 as a cooperative effort between the Lutheran and Catholic churches. The aim was "to train people at the grassroots level for ministry in the villages of the Arusha region." ${ }^{3}$ Both churches had several levels of ministers needing upgrading. TEE was viewed as a way of reaching all levels of ministers needing training, especially in the remote areas of the region. Church growth was rapid, but adequately trained leaders for the rapidly growing congregations were lacking.

A three-year program was established. Subjects covered biblical, historical, and christian theology in

\footnotetext{
${ }^{1}$ Ibid., 123 .

${ }^{2}$ Hogarth, 122 .

${ }^{3}$ Kinsler, Ministry by the People, 127.
} 
the African context. The teaching and the lessons were geared to relevance (i.e., God speaking to us where we are).

TEE enabled many more people to be trained than would have been possible through a residence program. Students were able to live and work with a minimum of family disruption. The church workers continued to serve their local congregations while being trained. As a result of the program, a close working relationship developed between the ministers and their congregations. ${ }^{1}$

\section{TEE in Botswana}

Botswana, which is dominated by the Kalahari Desert, has a land area about the size of France. Following independence a notable shortage of pastors developed. virtually every denomination with a history of theological training experienced a shortage. In some areas untrained men were recruited to pastor small congregations. A major reason for the shortage was that those having qualifications for theological study were being employed by the government.

The churches found themselves competing with the government and private industry for scarce man-power. Government could offer double a minister's stipend to a young man fresh from high school, at the same time appealing to his idealism with the call for unity and development. ${ }^{2}$

\footnotetext{
IIbid., 134, 135 .

${ }^{2}$ Ibid., 136 .
} 
A commission drawn from members of eight churches met in 1973 to study the problem. The commission recommended that an extension program be established. The primary reason for a TEE program was that the candidates would have to work at their jobs and study part time.

In 1974 the commission that had been formed decided to dissolve and form the Botswana Theological Training Program (BTTP). ${ }^{1}$ The BTTP consisted of five member churches: Anglican, Church of God in Christ, African Methodist Episcopal, Congregational, and Lutheran. The TEE program that the new organization developed offered ministerial training on three levels. The full ordination course was for five years. A twoyear lay leadership training course was the lowest level offered. Then there was an intermediate level for those wanting specific skills for ministry in the areas of administration, counseling, preaching, and teaching.

BTTP has used the analogy of a three-legged cooking pot to describe its TEE program. One leg represents study at home. The second leg represents the study of the group together in the weekly meeting. The third leg represents the practical application of what has been learned in actual church ministry. ${ }^{2}$ students

\footnotetext{
${ }^{1}$ Hereafter BTTP.

${ }^{2}$ Kinsler, Ministry by the People, 140.
} 
are told that the cooking pot will be effective only as all three legs remain strong.

The BTTP program has primarily trained men and women who have worked in the church for a number of years (i.e., those who have demonstrated their commitment and leadership capacity). Candidates have been found to be leaders of wisdom and profound experience of faith. The candidates for training lacked formal education only because they had never had the opportunity, not because they lacked ability.

\section{Lessons Learned from TEE Models and Experiences}

The majority of all TEE programs have been cooperative efforts. TEE popularity has been due to the inability of the residence programs to meet the needs of rapidly growing churches.

Proponents of extension education contend that it has solid historical, demographical, theological, and pedagogical justification for its existence. From the historical point of view, it has been observed that the "vast majority of pastors and priests in all ecclesiastical traditions were trained in the field or on the job."1 From the demographical point of view, it has been observed that TEE in Guatemala received its inspiration from geographical factors. Pastors lived

\footnotetext{
${ }^{1}$ Atkinson, 29.
} 
great distances from the residence schools.

From the theological point of view Kinsler makes the observation that

TEE breaks down the dichotomy between clergy and laity by encouraging all kinds of leaders to prepare themselves for ministry. It stimulates the dynamics of ministry at the local level by training those men and women in the context of their own communities and congregations. It enables the congregation to develop its own leadership for ministry, so they do not need to depend on outside highly trained professional clergy.1

From the pedagogical point of view, ward and

Rowen draw the analogy of a rail fence. The learning of knowledge and information is represented by the upper rail. The lower rail represents the field experience. The third component is the seminars represented by the fenceposts. ${ }^{2}$

Kinsler has rightly observed that the TEE movement "came into existence in response to a vast, urgent need that was not being met by traditional seminaries and Bible institutions."3 Though TEE has largely been a method encouraged by missionaries initially, Education, 8 .

${ }^{1}$ Kinsler, The Extension Movement In Theological

${ }^{2} T$. Ward and S. Rowen, "The Significance of the Extension Seminary," Evangelical Missions Quarterly (1972), 9:25-26.

${ }^{3}$ F. Ross Kinsler, "Open Theological Education," Theological Education (1974), 10:234. 
it has received enthusiastic response and is relevant at this point in the church's life when there are such numbers with a thirst for Biblical and theological training. But this initial warmth of reception will have to lead on to much greater involvement at every level of TEE by local people, everywhere, and to a far greater ability to truly contextualize materials and ministries, before maturity can be claimed for the movement as such. ${ }^{1}$

Much progress has been achieved in preparing locally contextualized and practically oriented materials by the programs of the African Independent Churches and the Arusha churches. ${ }^{2}$

In general, much progress has been made in enabling those who would never have had opportunity to attend a residence program to learn basic Bible truths and to gain self-confidence in their ministry. Moreover, a strong core of laymen has been prepared to serve well their local churches and to augment the work of their appointed pastors. ${ }^{3}$

One of the salient convictions from the TEE models and experiences is that it is biblical. Jesus and the apostles taught in the synagogues, homes, and even in the open fields; they were not confined to residence institutions. Many see a bright future for TEE in similarly meeting the needs of the many rural groups who

\footnotetext{
${ }^{1}$ Hogarth, 147.

${ }^{2}$ Ibid., 154 .

${ }^{3}$ Crider, 48 .
} 
have untrained local leaders. The hope is that most of those receiving TEE instruction will have the leadership ability to pass on to others the truths they themselves have learned. ${ }^{1}$

'Masih, 119. 
CHAPTER V

TEE AND ADVENTIST MINISTERIAL

EDUCATION IN RWANDA

\section{The Need}

The compelling need in Rwanda is to implement an educational program that would effectively break with the traditional structures and methods of higher education in order to reach those prime candidates who are now being excluded. Pastors, who never received ministerial training and have little formal education, and lay leaders in the churches, who have family responsibilities which prohibit them from entering a residence program even if they could meet academic requirements, must be helped to upgrade themselves.

\section{The Philosophy}

The philosophy of the proposed TEE program would be the same as that of the residence seminary. It would endeavor to provide adequate training for present and future leaders of the church. Well-equipped lay and pastoral candidates who graduate would be:

Thoroughly grounded in the word of God and equipped with the ability to proclaim it faithfully and responsibly; 
Appreciative of the role of the spirit of Prophecy in shaping and directing the development of the Adventist movement; and who endorse the continuing guidance of the Ellen G. White writings in the thought, life, and work of the church; Theologically discerning and stable, able to address current issues in proper perspective and provide reliable guidance to the church;

Able to lead to that assurance of the Gospel which is grounded in the life and work of Christ and made effectively present through the Holy spirit;

Assured that God's activity in human history has come to a special focus in the calling and mission of the Advent Movement;

Living witnesses in their life-style and testimony to the nearness of the coming of the Lord. ${ }^{1}$

\section{Practical Suggestions for Implementation}

The program would be a two-tier curriculum approach to extension learning. The proposed program would have its principle administrative headquarters in Kigali because of available permanent facilities and proximity to the RUM office. The diagram in figure 1 represents the varied system that would be followed. ${ }^{2}$ Each geographical location has a secondary school site which would become a TEE Center, with the exception of the headquarters which is a large evangelistic center complex.

Cross-fertilization would occur between resident students, the TEE candidates, and the other members of

\footnotetext{
${ }^{1}$ Andrews University Seminary Faculty Reaffirmation, "The Seminary and the Church: A Statement to the Constituency," James White Library, Andrews University, Berrien Springs, MI, 1981. TMs, pp. 4, 5.

${ }^{2}$ See Appendix $\mathrm{E}$ for map locations.
} 
the churches. Members who do not normally have the sort of intellectual contact that TEE provides would exchange ideas from their differing vantage points. Periodic contact with the resident students would also be enriching for the TEE students.

\section{KIGALI HEADQUARTERS \\ Administrative staff \\ course Tutors \\ students}

RWANKERI EXTENSION CENTER

Course Tutors

students
GITWE EXTENSION CENTER

Course Tutors

students

\section{NGOMA EXTENSION CENTER \\ Course Tutors \\ students}

Fig. 1. Extension Center site Locations.

Suggested academic divisions for the present project are detailed in figure 2. Of necessity the above academic divisions would result in a-two-tier approach. The first-tier level would be viewed as professional upgrading and continuing-education training. It would be heavily skills oriented, whereas the second-tier level would be sanctioned by the granting of a two-year intermediate-level diploma. Programmed learning texts would be required for both levels. 


\section{4}

Name of level

First-Tier

Second-Tier
Academic prerequisite

Less than primary school diploma/Functional literacy

Primary school diploma

Fig. 2. Academic Divisions Into Two Levels.

First-tier level students would receive certificates of achievement. Second-tier level students would receive two-year intermediate-level diplomas.

One objective of the proposed TEE program would be to train lay persons to be effective leaders in the congregations where they hold membership. Local churches would select and screen potential candidates. The candidates would be equipped as leaders for churches that do not have full-time pastoral leaders. Theological education would be extended to them. TEE would not be a general Christian educational program for all the church members to attend. It would be designed specifically for training leaders.

Another goal of the proposed TEE program would be to provide the tools for the continued growth of its candidates. Its objective would be nothing short of life-long learning and development. It would plant the seeds for a self-developing and self-sustaining ministry. The fruit of those seeds would result in the kind of practical ministry that the following story illustrates: 
I have read of a man who, journeying on a winter's day through the deep, drifted snow, became benumbed by the cold, which was almost imperceptibly stealing away his vital powers. And as he was nearly chilled to death by the embrace of the frost king, and about to give up the struggle for life, he heard the moans of a brother traveler, who was perishing with cold as he was about to perish. His humanity was aroused to rescue him. He chafed the ice-clad limbs of the unfortunate man, and, after considerable effort, raised him to his feet; and as he could not stand, he bore him in sympathizing arms through the very drifts he had thought he could never succeed in getting through alone. And when he had borne his fellow traveler to a place of safety, the truth flashed home to him that in saving his neighbor he had saved himself also. His earnest efforts to save another quickened the blood which was freezing in his own veins, and created a healthful warmth in the extremities of the body.1

It would be hoped that TEE graduates would make earnest efforts toward imparting the knowledge they have gained to the rank and file members of their churches. The process of sharing, helping, and training the church members would personally benefit the students and motivate them to greater learning levels. In addition, it would be a way to increase member participation in leadership responsibilities.

\section{Appropriate sites and structures}

The genius of the TEE program would be that it would build upon the strength of existing institutions. In order for the proposed project to achieve its desired objectives, there could be no duplication of resources.

${ }^{1}$ Ellen G. White, Testimonies for the Church, 
Resources must be combined to serve multiple functions. According to Kinsler, "Many of the first TEE programmes in Africa were started as extensions of theological education from existing schools." ${ }^{\text {Extensive facilities }}$ are not required. "About all that is really needed is a room that is suitable for classes to meet in."2 winter states that "by force of necessity Extension Centers have met for short or long periods in church sanctuaries, in homes, in sunday school buildings, in rented offices, and in many other types of surroundings." 3

Three secondary schools strategically located in the north, west, and south would be used in Rwanda for center sites. In addition, located in the east is a newly acquired facility that is presently being used as a training center. These sites would adequately accommodate the pilot project.

Traditional structures and methods of education would continue, but would be flexible in order to meet the varied needs of the extension students. The open University of Great Britain has done this effectively in order to achieve its primary goal of openness to the people it is committed to serve. The open University is built around the student who "is probably employed full-

\footnotetext{
${ }^{1}$ Kinsler, Ministry by the People, 105.

${ }^{2}$ Sprunger, 136 .

${ }^{3}$ Winter, 465 .
} 
time, and studies mainly at home in his spare time." 1 The same would be the case for those coming to the extension centers. Flexibility would be needed and would be essential to the success of the project.

\section{Staffing Considerations}

The most critical need in TEE development involves those who would actually coordinate the program and train the candidates. Fortunately, within the country are a number of persons both willing and qualified to give assistance in some way. Professors at AUCA have indicated a willingness to help during vacation periods. Teachers at the secondary schools could also help during vacation periods. The bulk of the responsibility, however, would fall upon departmental personnel.

The Union administrative officers would recommend the extension director, professors, and members of the TEE board to the Executive Committee of the Union for approval of the names. All matters of policy, program, and personnel would be decided by the Union Executive Committee upon recommendation by the TEE Board. Minutes would be kept of all meetings and decisions would then be circulated to the board members.

The principal authority would reside with the TEE

\footnotetext{
${ }^{1}$ Kinsler, The Extension Movement in Theological Education, 63 .
} 
Board. TEE would be administered as any other union institution. The curriculum and teaching staff would be approved by the Union Executive Committee by recommendation of the TEE Board.

The centers would be semi-autonomous. They would be linked to TEE headquarters academically so as to be able to extend credit and diplomas and at the same time would maintain their own staff and program. ${ }^{1}$

The centers would oversee the academic requirements of the recognized courses leading to the two-year diploma in accordance with the standards established at TEE headquarters. They would also offer courses for the lower-tier students who would follow the programmed instruction methods of learning.

Responsibilities for the TEE personnel at the centers would be carefully defined so as to avoid misunderstandings with residence personnel. Center staff would come primarily from Union departmental directors and graduates of the university who are now employed by the union. They would be answerable to the Union Ministerial Secretary.

'Winter, 460-461. 
Culturally Attuned Methods

of Teaching

One of the central issues of planning a strategy is addressed by the question: Should such a strategy be a completely new concept? It may be wiser to draw on the experience and learning of others. It has been stated that every year

hundreds of efforts are made to launch missions by persons with little or no experience in new church development and apparently little interest in drawing on the accumulated wisdom of those who do have considerable experience. . . Every day, people all across the continent are busy trying to re-invent the wheel.1

TEE has nearly thirty years of experience that can be drawn upon in the development of the pilot project in Rwanda. Baptist leaders have expressed a willingness to assist with getting another TEE program started in Rwanda. One of the distinctive features of TEE is that courses can be taught on different levels. While the residence program operates on a single level, TEE courses can be taken on different levels. students are simply given different assignments. Requirements are greater for the second-tier students than they are for the firsttier students.

${ }^{1}$ Lyle E. Schaller, Growing Plans (Nashville, TN: Abingdon Press, 1983), 121 . 
Programmed Learning Materials

Another feature unique to TEE is its use of selfstudy materials. Since the student only meets

occasionally with his teacher, the student's work at home influences the effectiveness of the program. Programmed learning materials have been developed to accommodate extension education which are geared for self-study.

Those involved in writing programmed

instructional materials accept four basic premises of programmed learning:

1. Learning proceeds best as the learner associates new information with information he already knows. (This is the old and still valid proposition that learning proceeds from the known toward the unknown--for example, Jesus used parables to link new information to things his hearers already understood: sowing seeds, fishing, investments, and caring for vineyards.)

2. Learning (retention) depends on the use of newly acquired information very soon after it is acquired. (This is the basis of the common tactic for better remembering a person's name--actually to say his name very soon after being introduced.)

3. Learning depends on the perceived importance of information. The importance of information must not only be indicated or demonstrated for the learner, but he must also experience a situation in which he finds that the information relates to his own purposes and goals. (A parent will often show a child an example of what happens if a certain teaching is ignored--for example, a drunken person will be pointed out as illustrating the consequences of abuses of alcohol.)

4. Learning (retention and accuracy) is increased when the learner is informed very promptly whether or not his use of new information is appropriate. (For example, Jesus gave Peter prompt 
and strong encouragement for announcing the deity he had recognized in Christ.) ${ }^{1}$

In Programmed Learning Texts, a short paragraph (frame) of information is first presented. Next, questions concerning the paragraph are asked. Immediate confirmation as to whether the answer was correct or not is then provided. This technique requires active study on the part of the student. It enables the student to know whether he is understanding or not.?

Five basic principles are followed in preparing programmed instructional materials:

1. Aims or objectives of each lesson are detailed and explicit. The subject is analyzed and broken down into component parts. Each day has a specific objective that builds toward the objective of the week.

2. Before a student begins the study of a topic, it must be ascertained what he actually understands of the subject. The prior knowledge of the student is what determines his starting point.

3. Steps must be carefully defined that will take the student from where he is to where he should be at the end of the course. He begins with seeing the

\footnotetext{
${ }^{1}$ Ted Ward and Margaret Ward, Programmed Instruction for Theological Education by Extension (Lansing, MI: Michigan State University, 1970), 9.

${ }^{2}$ Sprunger, 139 .
} 
(gospel) truth. He progresses to the level where he knows when he sees the truth. Next he remembers the truth in his own words. Then he memorizes the truth. After memorizing, he can distinguish the truth. The final level is where he uses the truth. The learning process does not limit the student to pre-existing truth. He becomes participatory in the process as he discovers truth and decides how to apply the truth to his situation.

4. There must be an active response from the student. Student response provides the interaction with teaching. Both written and verbal response are required.

5. Immediate opportunity for the student to confirm the teaching is provided. The student checks his own written answers with those provided in the textbook. Immediate feedback is also gained in the seminar meetings. ${ }^{1}$

\section{Weekly Center Meetings}

Where programmed materials are used, the textbook itself serves as the teacher. The input to the student comes from the text rather than the teacher. The function of the teacher is that of a facilitator. Instead of lecturing, the teacher is a resource person. on occasion a student may be called upon to function as a

\footnotetext{
${ }^{1}$ Hogarth, 38-40.
} 
teacher. As part of an assignment, the student may be given the opportunity to share what he is learning. Thus, he too becomes a catalyst for the learning process. This gives practical training to the student. Some graduates from the extension programs have proved to be among the best teachers. ${ }^{1}$

Scheduling and teaching methods are adapted to meet the needs of the students. Weekly meetings at each center are set up to give the student sufficient time to complete his lessons and to have regular contact with the professor. Scheduling would be flexible and would take into consideration distances, transportation availability, time, work, etc. One suggested format for a weekly meeting would be:

The first 20 minutes would be a 'Joint opening Session' of worship. The next 10 minutes would be used for 'General Housekeeping Procedures,' taking care of accounts, making necessary announcements and so on. This would be followed then by two seminar periods of 60 minutes each, with a 10-minute break in between. The seminar meetings would consist of a 10minute 'Review Exam of Week's Work,' 'to encourage the students to keep up with their daily work and to review.' The next 45 minutes would be for 'Discussion and Application,' where the 'student's work is checked and explanation made where necessary. The material learned is applied to actual life situations.' The last five minutes would be used for a 'Preview of Coming Materials,' 'to be sure that the next week's lesson is clear.' According to this plan, the basic format of an extension class would be review, discussion and application, and preview. ${ }^{2}$

\footnotetext{
${ }^{1}$ Sprunger, 141.

${ }^{2}$ Ibid. , 142-143.
} 
students usually meet from two to four hours weekly. Again, scheduling depends upon the students. Longer sessions could be scheduled if desired. These sessions stimulate the students and require them to be consistent in their studies.

\section{Monthly Center Meetings}

In addition to the weekly session, there may also be a monthly seminar. The monthly meeting brings all the students from the extension centers together in one location. Mid-term and final exams are usually administered at the monthly meetings. special features and speakers are planned for these meetings. These are special occasions for spiritual inspiration and fellowship.

One of the benefits of the student taking his studies over a long period of time is that he cultivates a habit of study. The goal of TEE is lifelong learning and not just graduation. students are to develop the attitude that there is always more to learn; learning thus becomes a lifetime process.

\section{Program Curricula}

The proposed TEE program would not be an attempt to eliminate the residence programs. It would be an attempt to extend the resources of the residence institutions to provide a more efficient system of 
education which would result in overall increased benefits for the church.

Most of the TEE-programmed learning materials used today have been predominantly prepared for those at the primary- and secondary-school levels. They are designed to give instruction to those who have had little exposure to theological training. The proposed TEE program for Rwanda would utilize programmed learning materials.

Evangel Publishing House in Nairobi, Kenya, has published a series of more than forty texts in cooperation with the Association of Evangelicals of Africa and Madagascar (AEAM) which are to be used in Theological Education by Extension in Africa. The texts on basic Bible and ministerial topics are written in such a way that students go through a carefully designed sequence of small steps to reach a specific objective. As the student progresses through the small steps, he is required to interact with the material by answering thoughtfully prepared questions. This method of study enables those with very limited education to succeed in a self-study program.

Each of the Programmed Learning Texts has lessons for ten weeks, a total of fifty in all. Specific objectives are reached each day and week through a series of ten to twenty short specially programmed steps. The 
end product to which each lesson moves is to equip the student with the ability to use the information taught in actual ministry. ${ }^{1}$

First-tier curricula

The books to be used for the first-tier curricula level would include the life of Christ series, the Acts of the Apostles series, the Looking at the old Testament series, the New Testament Survey series, Bringing People to Jesus, Christian Family Living, Helping People to Good Health, Helping the Church to Grow, Taking the Good News to Muslims, Talking to God, How to Preach, and Preaching From the old Testament. These texts would enable the student to learn how to study the Bible and even how to prepare a sermon. The questions would help the student to extract the principle thoughts from his study. Openended questions would challenge the student to develop his own solutions and approaches to the subject matter. In addition to the material provided by available Programmed Learning Texts, it would be necessary to have other prepared materials to round out the curriculum with relevant basic courses in church administration, music, polity, dogmatics, spirit of prophecy, prophecy, issues in church and ministry, and national language study.

\footnotetext{
${ }^{1}$ Hogarth, 30-31.
} 
Second-tier curricula

The basic curricula would be patterned after that formerly offered by Gitwe College as a terminal two-year ministerial training program. Programmed Learning Texts would be used wherever possible. Intensives would be used where Programmed Learning Texts have not yet been prepared. Course offerings would be as demonstrated in table $3 .^{1}$

Full-time study would be required in order to complete the above curricula in two years. Study, however, would proceed at the candidate's desired rate of speed. Motivation would be high because a diploma would be awarded upon completion. Pastors would have an additional motivation because salary rates and increments are now being tied to the level of education of a worker and his initiative toward upgrading himself. Each worker is placed in one of three categories and may progress to the highest category. Continued growth and development is necessary in order to reach the highest level. ${ }^{2}$

Mulholland has stated:

It would appear that unless extension education is presented as full-fledged ministerial training with transferable credits leading to a diploma or degree from a recognized institution, it will not be taken seriously by the lay leadership of the church. ${ }^{3}$

\footnotetext{
${ }^{1}$ See table 3 in Appendix $G$.

${ }^{2}$ See the Catagories in Appendix $\mathrm{K}$.

${ }^{3}$ Mulholland, 202-203.
} 
Transferable credits would not be the motivation for the proposed TEE program. It would be a terminal two-year intermediate-level ministerial training program only. Lay leaders could aspire though, and would be able, to obtain the same diploma as their pastor. Since they would be advancing with their pastors and gaining credits toward a diploma sought after by their pastors, credibility would be given to the program. Additional credibility would be given to TEE by its association with the established secondary schools. Graduation exercises for the diploma-level extension students would coincide with the regular graduations planned at the secondary schools.

TEE trainers would need to clearly define the role and function of relationships to be established between the district pastor and the local TEE-trained lay leaders. In line of authority, the district pastor would supervise the work of the lay leaders.

One of the problems with diploma-level courses has been the lack of available home study materials. Programmed learning materials presently available have not been prepared for university-level students. They would be, however, quite adequate for the two-year intermediate-level diploma being proposed through TEE. Although people in Rwanda have not been used to correspondence study, encouragement is coming from the 
office of the Minister of Education urging people to invest in correspondence courses. TEE could help change attitudes within the country which view extension education as inferior to the residence program.

\section{Financial Considerations}

Sprunger states that the extension seminary program has two primary purposes. The first is to train "present church leaders/ministers with limited training to gain additional theological education needed to make them more effective without taking them away from their present work."1 The second purpose is "to make possible the rapid opening of many new churches, at all levels of society, which are self-supporting, self-governing, and self-propagating." 2 His contention is that the present leaders and the potential leaders are the ones best qualified to insure that the second purpose is realized. Calculations would be needed to determine whether the proposed extension program could in reality be selfsupporting. The projected expenditures need to be determined. Comparative costs with the residence program would need to be calculated. Administrative and instructional costs per student would need to be figured. It would also be necessary to know the cost per unit

'sprunger, 153 .

${ }^{2}$ Ibid. 
taken and the cost per student study hour. When all the calculations have been made, the cost per graduate would then be figured. One of the benefits to the extension program is that people who are earning their own living and attending school are not as financially helpless as some living in the residence dormitory. Many of them should be able to pay their own way.'

Extension center financial operation

One of the largest initial expenses to the extension center operation would be the headquarters library. Provision would need to be made in the budget for an adequate library at the headquarters center. The other centers would be located at secondary schools and already have adequate libraries. Other expenses would include possible rent, utilities, teaching materials, textbooks, teacher salaries, transportation, and food.

Income for the operation would come from student tuition and subsidy assistance from their churches. Some staff members may be provided for, without charge, to the local center because of their regular teaching ministry for the Union. Special assistance could also be provided by the association from funds derived from offerings taken to help support the extension concept. An alumni

${ }^{1}$ Winter, An Extension Seminary Manual, 439-441 
scholarship fund may also be promoted for assisting a few worthy candidates. ${ }^{1}$

Avoiding potential problems

An effort must be made to prevent two possible dangers. The first danger is "the raising of the standard of living to the point where a student is no longer content to work among his own people." 2 This has been one of the major criticisms of the residence program. It has been stated that "If our educational system raises barriers between theological graduates and the rest of the people, the educational system must go." "3 Unfortunately, the missionaries have contributed to the above problem. Though their life-style may be somewhat lower than it was in their home country, it is still far above that of the people they serve. As a result, the national pastors-in-training generation expects to imitate the lifestyle and behavior of the foreign missionary. "This has created a tremendous burden on the resources of the churches . . because so much of the resources of the total Christian community

IIbid., 467-471 passim.

${ }^{2}$ Virgil Gerber, ed., Discipling Through Theological Education by Extension (Chicago, IL: Moody Press, 1980), 86-87.

${ }^{3}$ Kinsler, Ministry by the People, $x$. 
must go for the support of a professional class."1 The second danger is "the provision of scholarships that will for all future years orient the student toward the expectation of mission support."2 One possibility for correcting this would be to have a scholarship fund that functioned as a revolving fund. Loans would be made interest free, but the candidate would sign a contract to repay the loan after graduation. Needed assistance would thereby be made available but the student would eventually have the satisfaction of retiring the loan.

\section{Candidate selection}

The projections for future leaders of the church need to grow out of projected plans for church growth. If the membership is projected to double, then the number of leaders will need to double to maintain the same pastor/member ratio. It has been stated that "The world is to be evangelized, not by men invested with ecclesiastical dignities and with parti-coloured garments, but by men who have experienced the baptism of the Holy Ghost." ${ }^{3}$ The extension program begins with the students,

\footnotetext{
'Ibid.

${ }^{2}$ Gerber, $86-87$.

${ }^{3}$ Alexander Balmain Bruce, The Training of the Twelve (Grand Rapids, MI: Zondervan Publishing House,
} 1963), 523 . 
not with the structures. Often the reverse is true with the residence program. TEE would be a culturally sensitive approach to leadership development. It would identify as candidates for training those who have demonstrated their spiritual maturity, and then work to tailor an educational program to meet their needs. Candidates for TEE would come from the local churches. "The men reached by the extension seminary are the local leaders, deacons, elders, acting pastors and enthusiastic laymen."1 These individuals have already distinguished themselves as soul-winners and responsible leaders. They hold meetings, give Bible studies, and conduct the services of the church. They are seasoned members of the church and the other members look to them with confidence and respect: knowing that the training would enable these leaders to serve the interests of their local congregation better, the members would be more willing to give financially to assist them with their expenses.

A job description for a pastor is given in

1 Tim 3 and Titus 1 . The picture given in these passages is of a mature married man who has brought up his children to serve the Lord and manages his affairs well. This leader is a man of experience with a good reputation in the church and the community. Age is one of the

\footnotetext{
${ }^{1}$ Winter, 397.
} 
Monitoring of Candidate's Work

One of the most important characteristics of the proposed TEE program is that it would reach active leaders in their local churches. It would not extract them from their cultural context. They would continue their work, their ministry, and their local church affiliation. These are leaders of experience who regularly would relate the theory they receive to their weekly practice. since these students are already recognized leaders, their training, which would radically change their ministry to their local churches, would be highly valued.

The TEE teachers and coordinators who are placed in charge of the various centers would bear the responsibility for monitoring the work of the candidates. As they meet the students at the center, in church, or elsewhere, they would check on how the students are using their skills in their local churches. Members would be questioned when the teachers visit the churches as to the contribution the students are making to the local congregations.

Weekly center meetings would also be times for assessing the relationship of the student to the local congregation. Difficulties and successes would be shared during this time. The lessons themselves would also provide the students with questions that relate their 
studies to their own church situation. Daily the students would be making application of what they learn to the life and mission of the church in their local context. 1

Assignments would be checked at the weekly meetings. The assignments would be designed to relate the student's studies and his ministry in the local church. Some assignments might require preparation of sermons, special programs for the church, or analysis of real problems with suggested solutions.

How the student lives and serves in his church would be an important part of the monitoring process. Also important would be his participation in the educational process itself. Assignments, class involvement, and special activities sponsored by the center would all be vital parts of the evaluation of the candidate's progress.

\section{Advantages}

Great concern has been expressed by local church leaders over the loss of the former ministerial-training program. Some have advocated reinstituting the former course of study. Others have suggested doing as the Roman Catholics do in preparing priests. In a small seminary the candidates take secondary-school education,

\footnotetext{
${ }^{1}$ Ibid. , 498.
} 
sciences, and other subjects as required by the minister of education. However, their studies also include a carefully designed religious curriculum. Their course of study takes a year longer, but at the end they receive government diplomas. Proponents of this program contend that our secondary schools offer special sections for those taking science subjects, medical science, and the teacher-training course. Religion can be added as another section as the Roman Catholics have done. The problem this recommendation creates is one of finance and practicality. It would advocate every candidate entering the residence secondary-school program. The proposed TEE program would be superior because it redesigns ministerial training to accommodate the sincere interests of the more mature leaders already shouldering the leadership responsibilities in the local churches. They could continue in full-time employment while they receive their ministerial training.

\section{Effectiveness for Ministry}

TEE could help some of the present pastoral staff to upgrade to the intermediate-level diploma. A small number of under-educated pastors would never progress above the certificate level. Consideration could be given to helping some of the unproductive pastors become well-trained self-supporting Literature Evangelists. This would free their budgets for better-educated and 
higher-motivated workers. As lay elders they could make the same spiritual contribution they are currently making as employed workers. Moreover, the church would be better served by them in a lay-leadership capacity.

The above consideration could not be perceived as part of a TEE program for screening out unproductive workers. Immediate worker resistence would develop from such a perception.

\section{Obstacles to Implementation and How to overcome Them}

Traditional forms and practices of education make any new approach suspect. When it comes to the realm of religious beliefs and ecclesiastical structures, change is always difficult. Discussions of critical issues often flounder, or are dismissed, because of the difficulties changes would impose. TEE concepts advocate a task that is difficult and complex. In fact, it is an attempt "to revolutionize not only theological education but also the ministry, the church, and its mission in the world."1

Albert Long has observed that the Seventh-day Adventist Church in Rwanda is being in a certain way driven to pioneer the way for the World Church in finding a viable pattern of Adventist ministry in a society with rather few professional pastors and a multitude of untrained laymen. This 
work of pioneering can, therefore, be deeply significant. ${ }^{1}$

The difficulty of change would be overcome by the fact that it would become the role of the local church to choose the leaders to be trained. This grassroots approach to leadership development would give the local church ownership of the TEE program. It would be perceived as a solution to a felt need.

Members and workers have felt the suspension of the Ministerial course at Gitwe has contributed to the current shortage of qualified leaders. With the possibility of a two-year intermediate-level diploma, it is hoped that both pastors and laity would eagerly welcome the proposed TEE program. Many leaders have requested the re-institution of a ministerial training program. TEE would offer upgrading opportunities that go beyond what have frequently been requested.

\section{Apprehension over Remuneration}

Apprehensions over remuneration would be answered through TEE. It is anticipated that a structured TEE program would prepare a large cadre of unpaid leaders for the rural churches. The apostle Paul set an example for Christians in regard to the dignity of self-supporting labor. As he practiced his trade, he was able to reach a class of people that he may not have otherwise been able 
to reach. In addition, he demonstrated that the gospel could be preached effectively on a self-supporting basis. His example demonstrated that God is honored in the everyday exercise of gifts and talents that He has bestowed.

Similar opportunities exist today for those who will allow God to minister through them while they practice their trades. Ellen $G$. White has used as an example, Aquila and Priscilla, who were not called like the apostle Paul to give their whole time to the gospel ministry. She stated that "many others, upon whom human hands have never been laid in ordination, are called to act an important part in soulsaving."1 For these individuals, she states, "there is a large field open before the self-supporting gospel worker."2 Necessity demands that the church in Rwanda look to the merits of self-supporting church leaders. Presently in Rwanda there are many lay people who are eager to do much work for the church. They are not looking to the church for financial remuneration. Neither are these members looking forward to a time when the church would hire them because of the zeal and contribution they bring to its life and leadership.

\footnotetext{
${ }^{1}$ Ellen G. White, Acts of the Apostles (Mountain View, CA: Pacific Press Publishing Association, 1958), 355 . 
Fears of Lay ordination

Some have speculated that a TEE program would open the door to the ordination of an inferior level of candidates for ministry. Many churches in Rwanda are under the leadership of loyal, enthusiastic, and aggressive lay leaders. What they lack is training for the work they are actually doing. TEE would provide the perfect vehicle for bringing to them the training they desperately need. It would not be necessary to expect that their training would lead to remunerative employment or to ordination. Instead, it would give them the skills necessary to ensure uniform teachings and practices in the church. During times of crisis these members would act as competent apologists for the church. Some would be in the upper echelons of the professions and the civil service. The vast majority would be scattered throughout the rural areas of the country.

To avoid confusion with present church terminology, the TEE-trained lay leaders would not be called lay pastors. Instead, they would be called elders, preachers, leaders, or Bible workers. This would protect against possible future problems in regard to sustentation benefits claimed by those who are called pastors. The suggested titles would avoid all confusion among the members. Since to embark upon a non-paid ministry route would greatly depart from the present 
Adventist recognition of the "ministry" role everywhere, that concept has been eliminated from the scope of this proposal.

Fears about women

in Ministry

Though traditional forms of ministry are not presently being challenged in Rwanda, TEE would enable women the opportunity to study alongside men. Since resistance to having women elders and the ordination of women to the gospel ministry does exist, the emphasis of TEE would be upon training those who are actually carrying the leadership roles and are selected by their churches.

In many of the rural churches, women are the most qualified leaders in the congregations. Of necessity they are carrying prominent roles. Therefore, TEE would provide opportunity for them to become skilled in their ministries. Until now the public role of women has been quite limited. However, the rapid growth of members is changing that picture very quickly. The fact that they would be receiving training to pass on to others would commend the program to the local congregations.

\section{Challenge to the Traditional}

\section{Ministry}

Some will perhaps see TEE as a challenge to the traditional form of ministerial training. One fear is 
that it would have an adverse effect upon the ministry as it is constituted now. If fact, it has been suggested that a new type of pastor might emerge. The question being asked is "will the face of the church change profitably (or not) if many more become trained as fulltime or part-time pastors through the extension method?"1 The underlying concern is that TEE will produce "cheap pastors." There is an apprehension that the level of ministry might be lowered instead of being raised. The proposed TEE program would not be replacing the residence program. Instead, it would reach those not being helped by the residence program.

Those who are presently in ministry without adequate preparation would be the beneficiaries of TEE. Levels of pastoral ministry have already been established in Rwanda. ${ }^{2}$ TEE would assist pastors in upward mobility in the existing categories.

Fears of a More

Educated Laity.

Keeping the laity in ignorance in regard to theological matters is counter-productive. Many of the laity now devour any printed materials they can obtain. It does not matter which church group or which dissident group provides the materials for reading. All are

${ }^{1}$ Hogarth, 158.

${ }^{2}$ See Categories in Appendix $\mathrm{K}$. 
eagerly consumed. Then they are used for teaching purposes.

TEE offers the best assistance that church leaders could wish for in order to counteract the effects of objectionable tracts and materials. It provides key leaders with the solid biblical training they need to help the members be more discriminating in their reading and in what they accept as credible material.

\section{Expected Outcome}

The desired result of the proposed TEE project is to equip God's people in Rwanda for ministry. The expected outcome has been well stated by Kinsler:

Theological education by extension opens up an avenue for the churches to transform their own structures, placing power and initiative in the hands of the whole people of God. This in turn may enable the churches to become a servant people, counter communities whose prophetic message is accompanied by living witness and liberating ministry. ${ }^{1}$

\footnotetext{
${ }^{1}$ Kinsler, "Theological Education by Extension: Service or Subversion?" Missiology 6 (1978): 196.
} 


\section{CHAPTER VI}

CONCLUSION

\section{Summary of Issues}

The task of this project was to develop a workable strategy for a pilot Theological Education by Extension program to train pastors and laymen in the Rwanda Union Mission of Seventh-day Adventists.

\section{Crisis Situation}

This study has attempted to describe the present crisis situation facing the SDA church in Rwanda today. The church is faced with a rapidly growing membership and a shortage of trained leaders to tend it. Ministerial training, formerly offered as a terminal two-year intermediate-level program at Gitwe college, was suspended in order to give full support to AUCA, the new university offering an overall plan to upgrade the ministry. The suspension of the ministerial training program at Gitwe has resulted in a vacuum of locally qualified leaders for service at the lower church levels. 
Rapid Numerical Growth

This proposal has shown that in the history of the SDA church in Rwanda, rapid numerical growth has primarily been associated with the work of the laity. Every member was encouraged to bring one person to the weekly services. Training schools of evangelism were established which made the laity more effective in bringing people into church membership. The effectiveness of the strategy is what has created the present crisis situation. Growth became so rapid that attempts were made to slow down the evangelism pace to enable adequate training of leaders to care for the new members.

\section{Lack of Well-Trained Leaders}

This proposal has revealed that the heart of the problem facing the church has been the question of leadership. Ministerial training was started at Gitwe for the purpose of preparing professionally qualified leaders. The church must now look exclusively to the university for its leaders. Some members who have been privileged to receive university training are often lured away from serving the church by the high salaries offered in the public sector. Others, after graduation, are willing to serve only in the developed areas. As a consequence, member losses to the Adventist church have 
been, in part, "due to the lack of an adequately trained pastoral ministry." 1

Educational Elitism

Many leaders currently engaged in ministry are unable to get access to the training they require because they lack a secondary diploma. Academic prerequisites make it impossible for those of limited educational background to progress scholastically even if they have the required diploma. Only a select few are benefiting from the educational institutions being operated by the SDA church in Rwanda. Furthermore, even if a person is academically qualified, financing a program at AUCA is impossible for the average person.

Due to the poverty of the country, the lack of income of the individual members, the existing financial constraints of the local churches, the institutionalism of the church which focuses financial resources on the traditional educational approaches to learning, and the dependency upon Western approaches to education which require large capital investments in buildings and personnel, many prospective church leaders are excluded from formal training programs.

\footnotetext{
${ }^{1}$ Long, 147 .
} 
Traditional Methods

Not Sufficient

The proposal has shown that traditional methods of training are not adequate to meet the growing need of leaders in many parts of the world. only a select few are benefiting from the educational institutions being operated by the SDA church in Rwanda. In addition, local SDA churches have proved ineffective in training members to meet local community needs. Members bring their friends and neighbors to church, but they lack skills in how to train and prepare candidates for membership. TEE was developed precisely for the purpose of addressing the need to train leaders for the local churches. Church leaders and educators in Latin America, India, the Far East, and Africa have been encouraged by the potential of TEE programs to supply the lack of untrained local leaders. TEE reaches active leaders in their local churches. It does not separate them from their cultural context. They continue their work, their ministry, and their local church affiliation.

\section{Proposed Solution}

The primary goal of this proposed TEE program has been shown to be the training of present and future leaders of the church. It advocates breaking with the traditional structures and methods of higher education in order to reach those primary candidates who are being 
excluded. Pastors, who never received ministerial training and have little formal education, and lay leaders in the churches, who have family responsibilities which prohibit them from entering a residence program even if they could meet academic requirements, would now be able to upgrade themselves.

Certainly TEE is not an end in itself. However, TEE has been successful in satisfying the needs of pastoral training and nurture in many other countries.

The church naturally produces leaders who rise to the fore whenever the need arises. The ministry of the church is carried on by the people of the congregation. They minister under the power of the Holy spirit and by the gifts of the Holy Spirit. Theological education by extension can no more produce the gifts of the spirit than can resident schools. ${ }^{1}$

The aim of the proposed TEE program would be to allow men and women in Rwanda who have received the gifts of God for ministry to receive training.

\section{Expected Results}

The desired results of the proposed TEE program would be a better-trained ministry. A number of areas of leadership should be enhanced by TEE.

1. Pastoral nurture. District pastors would be helped personally by TEE training to better serve the interests of their churches and communities. As lay leaders would receive TEE training, their pastors would

\footnotetext{
${ }^{1}$ Mackinnon, 104 .
} 
experience improved leader assistance with the nurture of the members.

The TEE students would be constantly studying, sharing, and applying the word of God. They would come to better appreciate the wholistic message of Scripture. Many now have a vague understanding of the process of salvation by which God restores sinful human beings to His image. TEE would help leaders understand that the restoration process has to do with the physical, mental, social, and spiritual dimensions of all humanity who share this sinful earth.

2. Evangelistic Outreach. Improved training should improve the capability of the leaders to more effectively extend the invitation of the gospel to others. Through the regular in-service training of TEE (which does not remove the leader from ministry but is well-suited for the local situation), leaders would be equipped and challenged to better manage and administer the affairs of the rapidly growing SDA church in Rwanda.

3. Discipling members. The church is not divided between clergy and laity. It is made up of ministers. All members are to be ministering within and without the church. All members have the responsibility to minister and witness.

Spiritual growth is accelerated in the lives of those members who are actively contributing to the life 
and mission of the church. Where pastors do not train their laity to carry leadership roles, or fail to delegate responsibility and authority, members do not take their involvement in the life of the church as seriously as their active counterparts. Members who do not shoulder responsibilites become passive and tend to want to pass off, as much as possible, to the pastor things they themselves could easily do.

Those who have been members of small congregations have experienced the necessity of every member being required to "pitch in" and carry forward the work of the church. The true fellowship of genuine involvement and responsibility is something coveted by those who have been privileged to have the experience.

$$
\text { 4. Life-long learning. A final goal of this }
$$

proposed TEE program would be to provide the tools for the continued growth of its candidates. Its objective would be nothing short of life-long learning and development.

Personally, I believe training for the ministry in contemporary Africa is ready for the take-off. We have the plane, we have filled the engine with fuel, we have taxied down the run-way, we have revved up the engine--and there we sit delaying the take-off. Training for Ministry in contemporary Africa--it is time for take-off $!^{1}$

'Paul E. Hoffman, ed., Theological Education in Today's Africa (Geneva, Switzerland: Lutheran World Federation, 1969), 7 . 


\section{Recommendations}

1. Administrations of the RUM and AUCA should critically study the proposed TEE program.

2. If the RUM accepts the TEE proposal, and AUCA supports the concept, request should be made by the RUM to AUCA to schedule their teachers during vacation breaks, and on a limited basis during the school year, to participate in TEE training and seminars.

3. RUM should request AUCA to give study to preparing Programmed Learning Texts as an industry to provide student labor.

4. Since the proposed pilot project would not grant ministerial status to self-supporting lay leaders, study should be given by the RUM to that possibility in the future.

5. A widened ministry for the TEE-trained graduates should be considered. Presently only ordained pastors are allowed to baptize new adherents. Study should be given to granting that privilege to the TEE graduates. Such an action on the part of the RUM would give increased credibility to the TEE program and to its graduates.

\section{Concluding statement}

Perhaps one of the major concerns that surface with regard to any propositions regarding "lay preachers" is the fact that the church has become so dependent upon 
professionals that the members are prone to see selfsupporting preachers as "second-best." The clergy are not presently facilitators. They are in charge of duties that laymen could and should be performing.

The proposed pilot project would put lay leaders in charge of those duties that they could and should be performing. Major administrative responsibility would reside with the full-time salaried B.A.-trained pastors. Those pastors require advanced living standards. They require either a motorcycle or vehicle for transportation. Their future employment can only be possible if they are fewer in number with greatly expanded district responsibilities. Each pastor must be responsible for twenty to thirty churches.

Somehow the value of our laity to the accomplishing of the Gospel commission must be rediscovered. There is really no better alternative. As local members would utilize their talents and abilities to the glory of God, a revitalization of the whole church and its individual members would surely result. 
APPENDIX 
APPENDIX A

RATE OF GROWTH STATISTICS 
mppendix A

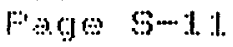

\author{
AFFITCA-WNDAN OCI:AN DTUTSTON
}

RWANDA UNION MISSION

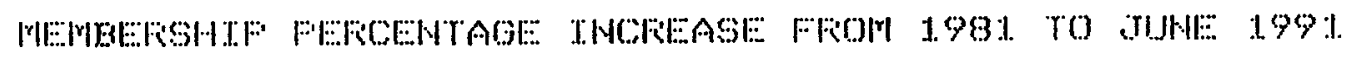

RATE OF GROWTH

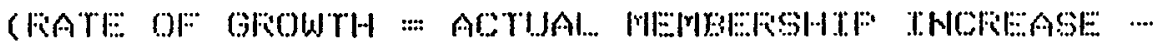

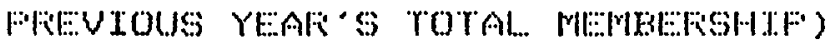

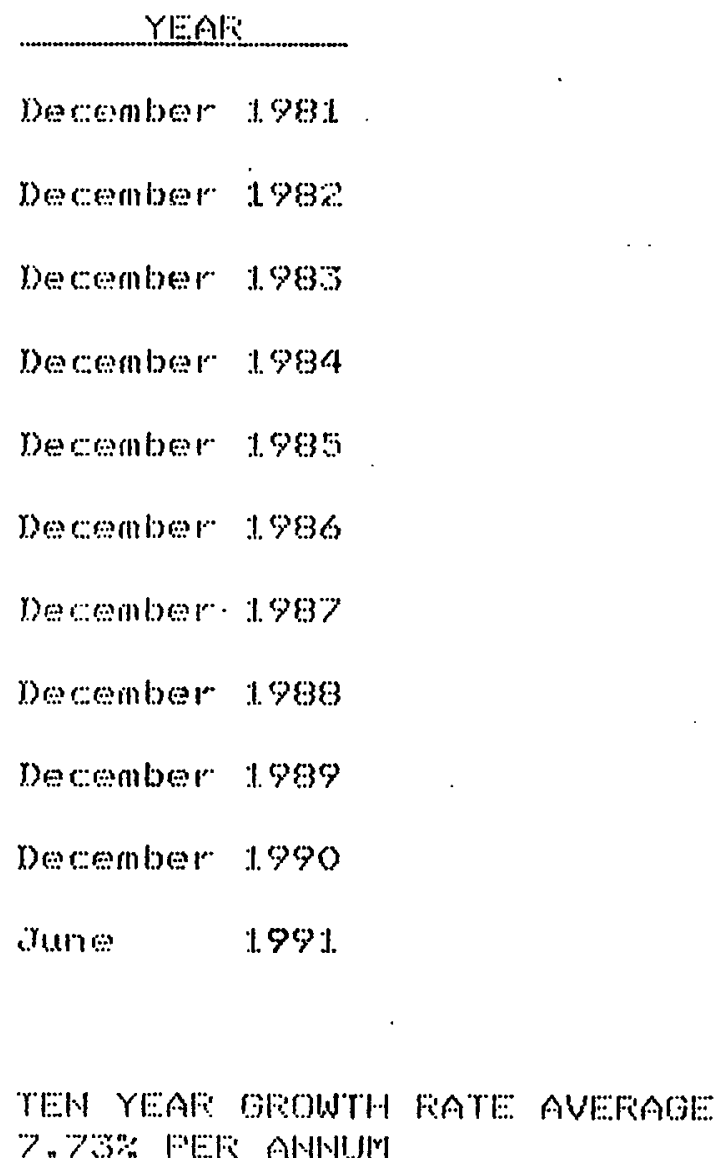

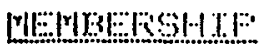

1.4 .61 .8

1. 1.94289

$133.80 \%$

1.42 .381

1. 53,633

1. 649.209

$1.73,761$

1833 y $20 \%$

2059.316

223.730

$200250 \%$
OFOLTH

$\left(A p p r o x_{n}\right)$

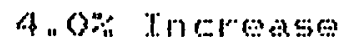

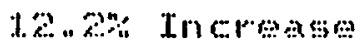

$6.4 \% \ln (x) \Leftrightarrow$

$7.9 \% \operatorname{lncrease}$

$7.6 \%$ Th

5. l. thereas

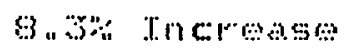

9. 17 Thorease

$9.0 \% \operatorname{tn} x \operatorname{sen}$

3.

$7.73 \%$ FEN ANNUIN 
APPENDIX B

STATISTICAL COMPARISONS

NUMBER OF MEMBER PER PASTDRAL WORKER 
Appendix $\mathrm{B}$
Page $5-6$
AFFICA-INDIAN OCEAM DIVISION

NUMESER OF MEMBER FER FASTOFAL WOFKER

30 June 1990

\begin{tabular}{|c|c|c|c|c|c|}
\hline OFDA TINED & \multirow{2}{*}{\multicolumn{2}{|c|}{$\begin{array}{l}\text { L.ICEHSED } \\
\text { MINTSTEFS }\end{array}$}} & \multicolumn{3}{|c|}{ NUIMBEE OH MEIMEEFES } \\
\hline MTHISTEKS & & & FEF & FASTO & A.... \\
\hline DEC 19902 & (DEC 1990) & IOTAL & 1991 & 1990 & 1989 \\
\hline 79 & 70 & 149 & 354 & 338 & 282 \\
\hline 71 & 29 & 100 & 356 & 320 & 286 \\
\hline 113 & 103 & 216 & 446 & 422 & 432 \\
\hline 174 & 29 & 203 & 1., 145 & 1,125 & 1,040 \\
\hline 26 & 18 & 44 & 150 & 160 & 147 \\
\hline 97 & 95 & 192 & 862 & 899 & $\$ 26$ \\
\hline 199. & 159 & 358 & 393 & 613 & 577 \\
\hline 25 & $2 a$ & 53 & 619 & 01.2 & 518 \\
\hline$=$ & $\begin{array}{l}531 \\
==\end{array}$ & $1,1.35$ & $\begin{array}{l}656 \\
===\end{array}$ & 629 & 58 \\
\hline
\end{tabular}




\section{APPENDIX C}

\section{DEBT ANALYSIS FIGURES}


1. Hablt patterns have become well establlshed. Change, and the necessity for austerity, are not necessarily popular.

2. Some of us still cling to the hope that as our needs increase so will the flow of outside funds to us.

3. We may find it difficult to concelve of the possiblitty of rapld membership growth and a shrinking of the moneg supply when we feel our needs are the greater.

In addition to the above some find themselves in the distressing position in which disposable income of much of the membership is severely cut. A prime example of this is zaire:

The $1990100 x$ wage factor was equivalent to about US\$100. From

$\therefore$ January the wage factor was increased fourfold in terms of local currency, but by June it was worth only, US\$43.

In a runaway inflation/devaluation situation the earning power of the average individual does not necessarily keep pace with the economic slide. Self-support of the church becomes more and more a seemingly unachievable goal.

\section{THE EXTENT OF INDEBTEDNESS}

The following statistics (based on Information avallable June 30 ) 111ustrate the difficult situation in which the Division finds itself. This data 19 presented with the intent that it alght arouse us to Identify just why we are in the situation in which we find ourselves, and to motivate us to initiate whatever strategies are required to reallze a recovery before we pass the point of no return.

Total Indebtedness of Sub-organtzations to Unions (In CFA)

Burundi Association Central African Union

Indian Ocean Union

Nigerian Union

Rwanda Union

Sahel Unton

West African Union

zalre Union
2435938

194954202

55093632

$\begin{array}{lll}36 & 773 \quad 813\end{array}$

103792266

96233968

141502390

36984750 
TREASURER'S REPORT -- AID

November 1991

Rwanda Union:
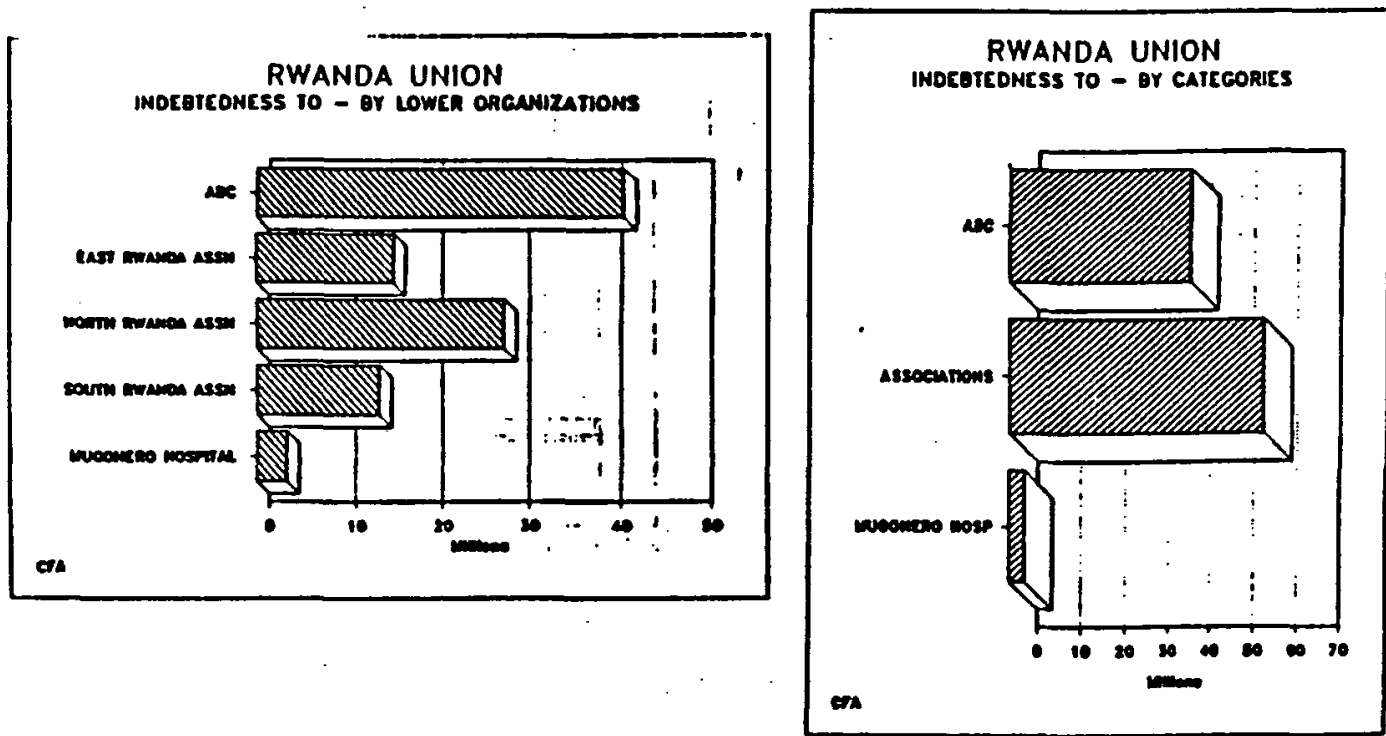

Sahel Unton:
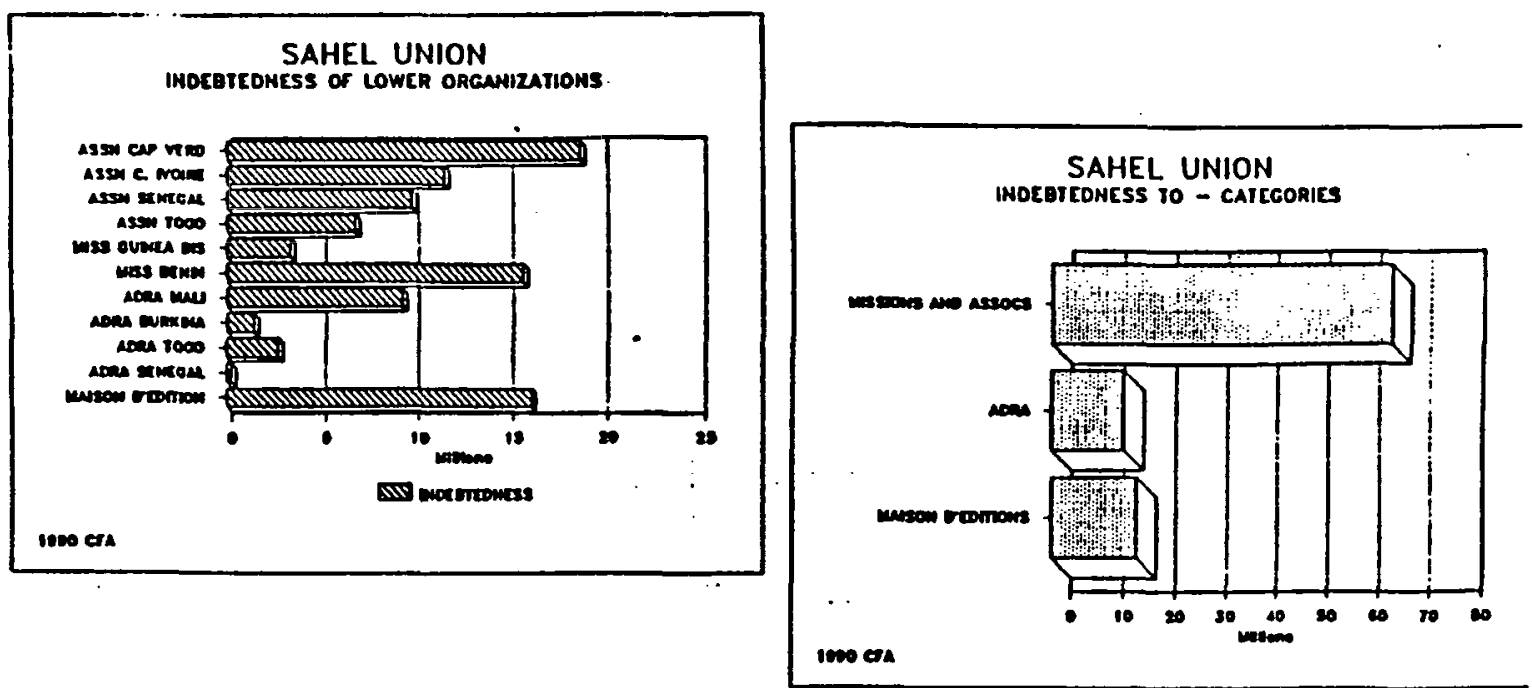
TREASURER'S REPORT -- AID November 1991

Indebtedness of Unions and Ald Inst ltutions (June 30 )

(Sept $\cdot 91)$

\begin{tabular}{|c|c|c|c|c|c|}
\hline Burundi Assoclation & 159531 & $029)$ & $(46$ & 434 & 040) \\
\hline Central African Union & 150699 & 164) & 112 & 706 & 463) \\
\hline Indian Ocean Union & (15 819 & $079)$ & 146 & 326 & 259) \\
\hline Nigerian Union & 18453 & 932) & 5 & 601 & 934 \\
\hline Rwanda Union & 75039 & 088 & 57 & 958 & 301 \\
\hline Sahel Union & 156232 & 541 & 101 & $90 \underline{1}$ & 262 \\
\hline West African Union : & 155654 & 067 & 145 & 708 & 530 \\
\hline Zaire Union & 48749 & 380 & 64 & 531 & 147 \\
\hline ASWA & $(1 \cdot 978$ & 425) & 19 & 284 & $862)$ \\
\hline AUCA & 122978 & 266) & 7 & 034 & 153 \\
\hline IMA & 57950 & 734 & 45 & 087 & 527 \\
\hline Advent Press & 113853 & 165 & 139 & 355 & 749 \\
\hline ADRA & 7543 & 372 & 38 & 362 & 765 \\
\hline AID Church School & 1794 & 988 & 4 & 039 & 625 \\
\hline Cooper Clinic Loan & 32450 & 000 & 31 & 350 & 000 \\
\hline Mauritius Conference Loan & 4405 & 517 & 4 & 481 & 379 \\
\hline Rwanda Union office Bld Loan & 21402 & 190 & 17 & 541 & 750 \\
\hline \multirow[t]{2}{*}{ BurundI Assn Loan } & 83039 & 714 & 65 & 358 & 967 \\
\hline & סSט & 214 & 13 & 561 & 465 \\
\hline
\end{tabular}

While it may appear that we are belabouring the point, chronic indebtedness 18 not something which has no serious effects upon the operation of the church throughout the Division. 
APPENDIX D

STATISTICAL PROJECTIONS 


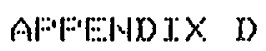 \\ FUANDA UNTON MTSSTON

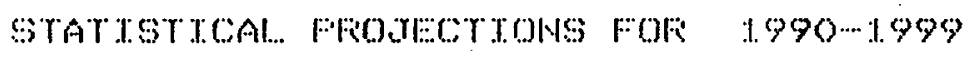

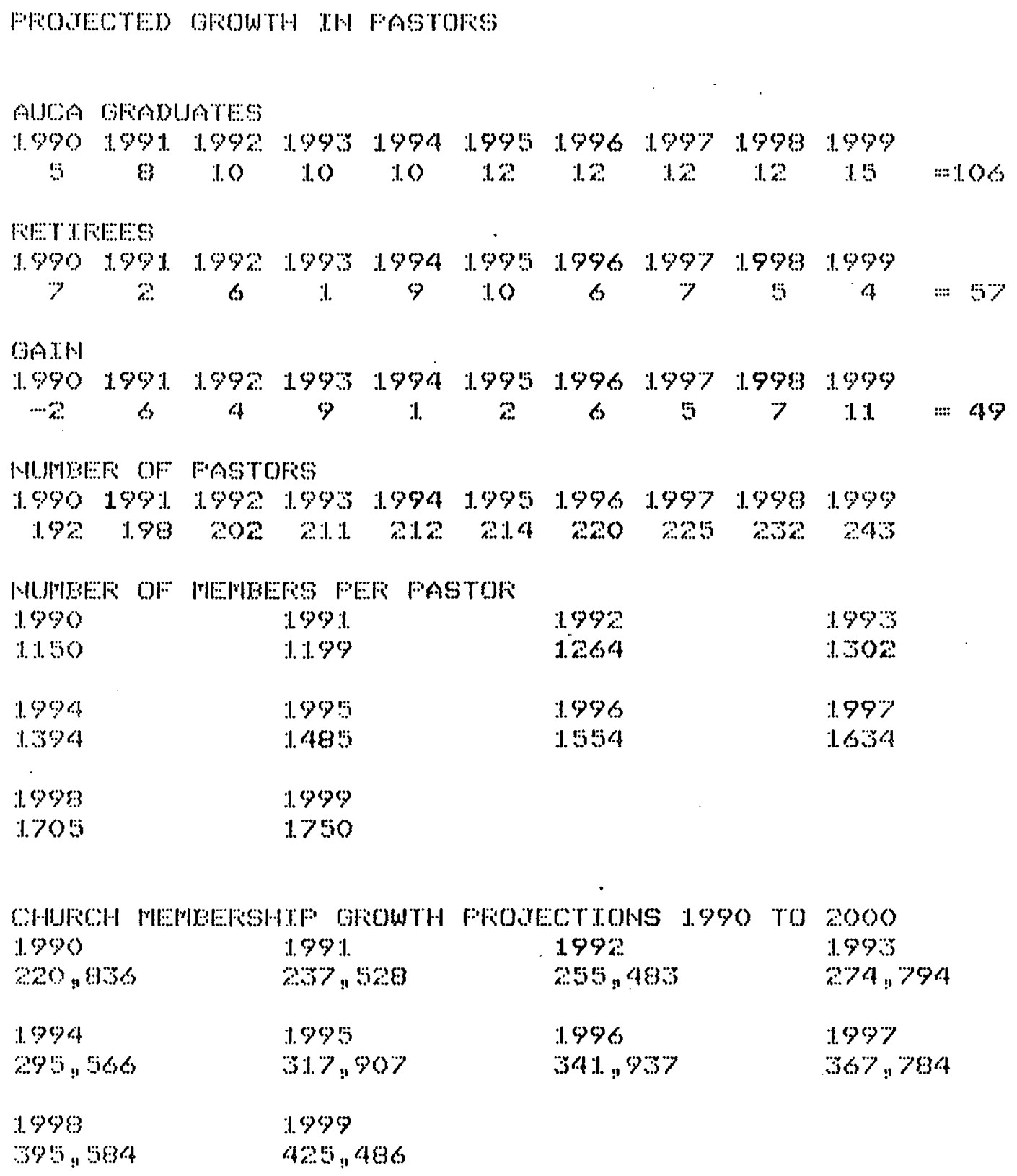

THEN YEAF GHOWTH FIATE CALCULATED AT

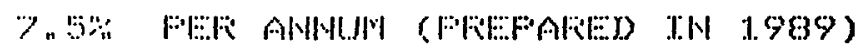




\section{APPENDIX E}

MAPS 


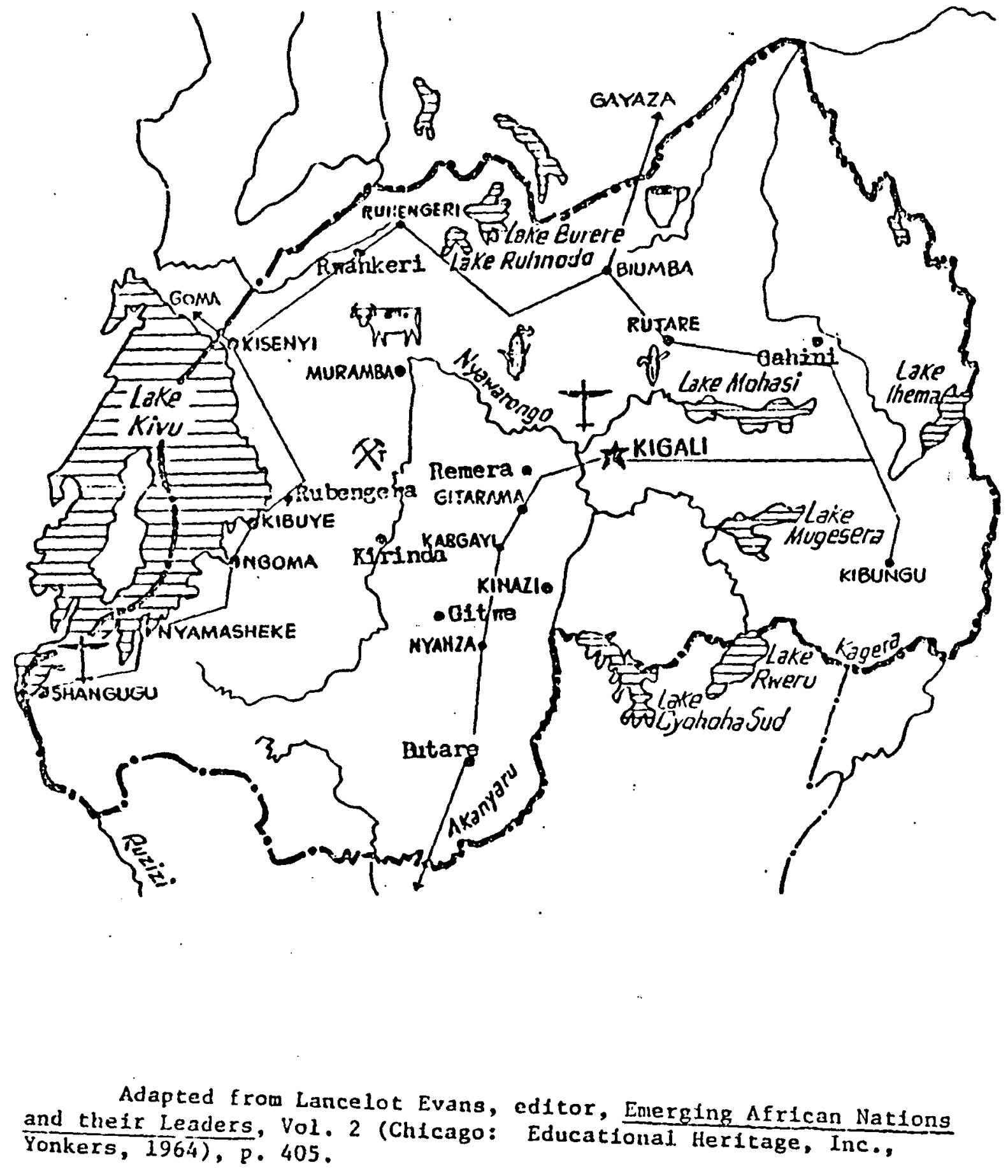




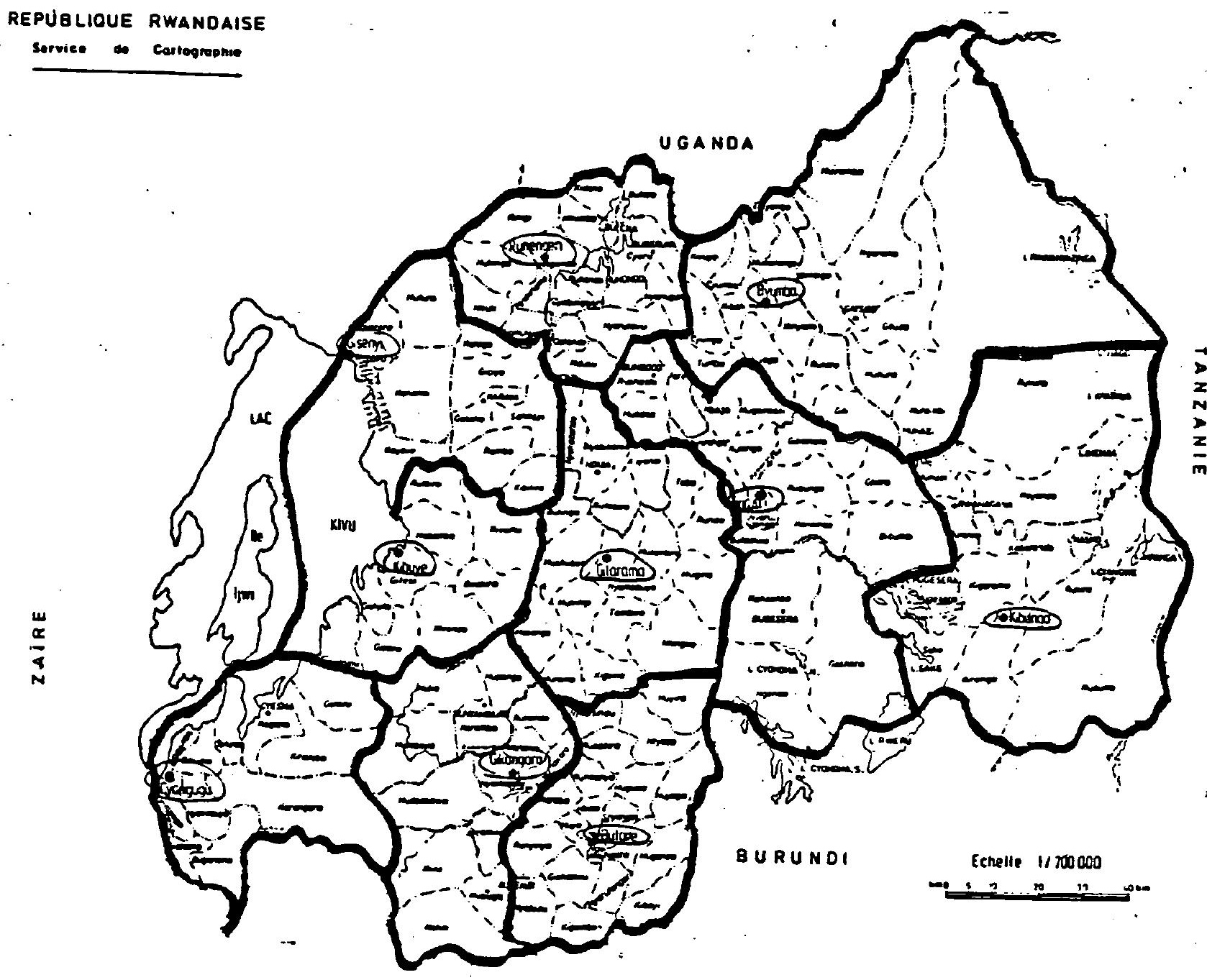




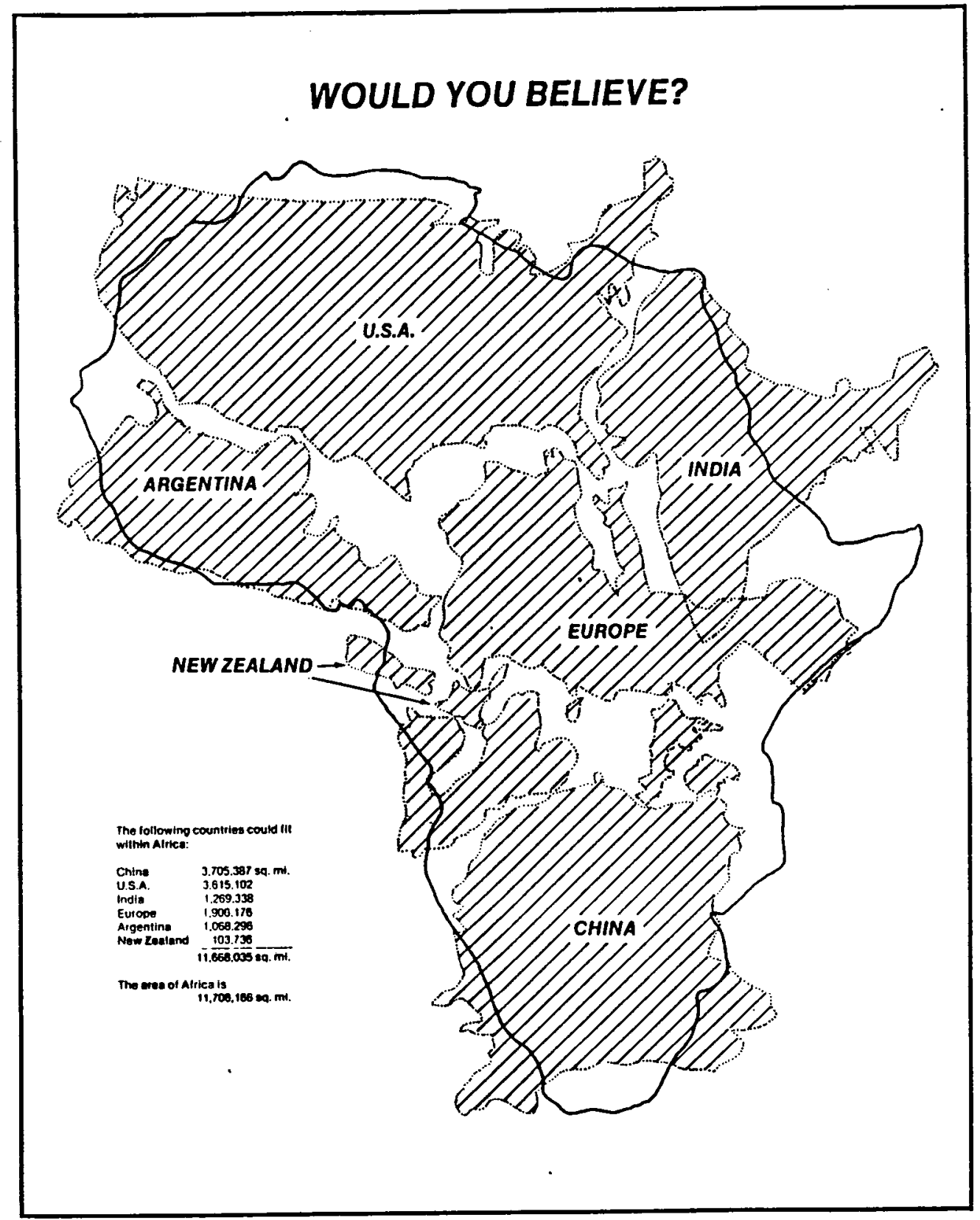

- World Eagle, Ins, 1981. Reprinted with permission from Africa Today 1987 revised edition (64 Washburn Avenue, Wellesley, Massachusetts 02181). 
APPENDIX $F$

ECONOMIC AND SOCIAL STATISTICAL COMPARISONS

ENGLISH TABLES ARE FOR 1988

FRENCH TABLES ARE FOR 1992 


\section{THE STATE \\ OF THE WORLD'S \\ CHILDREN \\ 1988}

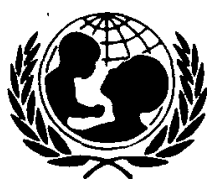

James P. Grant

Executive Director of the

United Nations Children's Fund

(UNICEF)

PUBLISHED FOR UNICEF

Oxford University Press 


\section{General note on the data}

The data provided in these tables are accompanied by definitions, sources, explanations of signs, and individual footnotes where the definition of the figure is different from the general definition being used. Tables derived from so many sources - nine major sources are listed in the explanatory material - will inevitably cover a wide range of reliability. Official government data received by the responsible United Nations agency have been used wherever possible. In the many cases where there are no reliable official figures. estimates made by the responsibie United Nations agency have been used. Where such internationally standardized estımates do not exist. the tables draw on data from the relevant UNICEF field office. All data from UNICEF field office sources are marked with * or $Y$.
The figures for under-five and infant mortality rates. life expectancy, crude birth and death rates, etc., are part of the regular work on estimates and projections undertaken by the United Nations Population Division. These and other international estimates are revised periodically which explains why some of the data will differ from those found in earlier UNICEF publications. In the case of GNP per capita and ODA, the data are the result of a continuous process of revising and updating by the World Bank and OECD respectively.

Where possible only comprehensive or representative sample national data have been used although, as in the table on "Wasting", there are certain exceptions. Where the figures refer to only a part of the country, this is indicated in a footnote

\section{Signs and explanations}

Unless otherwise stated, the summary measures for the four U5MR (under-five mortality rate) groups of countries are the median values for each group. The median is the middle value of a data set arranged in order of magnitude. The median is the average com monly used where there are a large number of items of data with a great range. as is the case in these tables. and it has the advantage of not being distorted by the very small or the very large countries. In cases where the range of the data is not all that extensive, the most commonly used average is the mean, which is the sum of all the values divided by the number of the items. However, because we are dealing here with countries of very different sizes of population, we would immediately encounter the problem of weighting, if we used the mean. Hence the choice of the median to give the reader some idea of the situation in a typical country of the appropriate U5MR group.

. Data not available.

* UNICEF field office source

(.) Less than half the unit shown.

T Total (as opposed to a median).

$X$ See footnote at the end of the tables.

$Y$ UNICEF field office source; see footnote at the end of the tables

Most of the U5MR figures are interpolations based on five-year estimates prepared by the UN Population Division on an internationally comparable basis using various sources. In some cases. these interpolated estimates may differ from the latest national figures. 
TABLE 1: BASIC INDICATORS

\begin{tabular}{|c|c|c|c|c|c|c|c|c|c|c|c|c|c|}
\hline & & \multicolumn{2}{|c|}{$\begin{array}{l}\text { Under } 5 \\
\text { mortality } \\
\text { rate }\end{array}$} & \multicolumn{2}{|c|}{$\begin{array}{l}\text { Intant } \\
\text { mortality } \\
\text { rate } \\
\text { (under 1) }\end{array}$} & \multirow{2}{*}{$\begin{array}{l}\text { Total } \\
\text { population } \\
\text { (milions) } \\
1986\end{array}$} & \multirow{2}{*}{$\begin{array}{l}\text { Annual no. of } \\
\text { births infant } \\
\text { and child } \\
\text { deaths }(0-4) \\
\text { (thousands) } \\
\text { 1986. }\end{array}$} & \multirow{2}{*}{$\begin{array}{l}\text { GNP } \\
\text { per capita } \\
\text { (US \$) } \\
1985\end{array}$} & \multirow{2}{*}{$\begin{array}{l}\text { Life } \\
\text { expectancy } \\
\text { at birth } \\
\text { (years) } \\
1986\end{array}$} & \multirow{2}{*}{$\begin{array}{l}\text { of adufts } \\
\text { literate } \\
\text { male/fernale } \\
1985\end{array}$} & \multirow{2}{*}{$\begin{array}{l}\text { \%o of } \\
\text { 3ge group } \\
\text { enrolled in } \\
\text { primary school } \\
\text { male/female } \\
1983-86\end{array}$} & \multicolumn{2}{|c|}{$\begin{array}{c}\text { कo share } \\
\text { of househok } \\
\text { income } \\
1975-85\end{array}$} \\
\hline & & 1960 & 1986 & 1960 & 1986 & & & & & & & $\begin{array}{l}\text { towest } \\
40 \% \%\end{array}$ & $\begin{array}{l}\text { higt } \\
20\end{array}$ \\
\hline & $\begin{array}{l}\text { Very high U5MR } \\
\text { countries (over 170) } \\
\text { Modian }\end{array}$ & 308 & 211 & 185 & 130 & $477 T$ & $22519 \mathrm{~T} / 4730 \mathrm{~T}$ & 280 & 47 & $43 / 22$ & $71 / 48$ & $\ldots$ & \\
\hline $\begin{array}{l}1 \\
2 \\
3 \\
4 \\
5 \\
\end{array}$ & $\begin{array}{l}\text { Afghanistan } \\
\text { Mali } \\
\text { Sierra Leone } \\
\text { Malawi } \\
\text { Ethiopia }\end{array}$ & $\begin{array}{l}380 \\
370 \\
397 \\
364 \\
294 \\
\end{array}$ & $\begin{array}{l}325 \\
297 \\
297 \\
270 \\
255 \\
\end{array}$ & $\begin{array}{l}215 \\
210 \\
225 \\
206 \\
175 \\
\end{array}$ & $\begin{array}{l}185 \\
171 \\
171 \\
153 \\
151 \\
\end{array}$ & $\begin{array}{r}17.2 \\
8.3 \\
3.7 \\
7.2 \\
44.7 \\
\end{array}$ & $\begin{array}{c}863 / 280 \\
421 / 125 \\
174 / 52 \\
384 / 104 \\
2228 / 568 \\
\end{array}$ & $\begin{array}{r}150 \\
350 \\
170 \\
110 \\
\end{array}$ & $\begin{array}{l}39 \\
44 \\
36 \\
47 \\
42 \\
\end{array}$ & $\begin{array}{l}39 / 8 \\
23 / 11 \\
38 / 21 \\
52 / 31 \\
\ldots . \\
\end{array}$ & $\begin{array}{c}24 / 11 \\
29 / 17 \\
68^{x} / 48^{x} \\
71 / 53 \\
44 / 28\end{array}$ & $\begin{array}{l}\cdots \\
\cdots \\
\cdots\end{array}$ & \\
\hline $\begin{array}{r}6 \\
7 \\
8 \\
9 \\
10 \\
\end{array}$ & $\begin{array}{l}\text { Guinea } \\
\text { Somalia } \\
\text { Mozambique } \\
\text { Burkina Faso } \\
\text { Angola } \\
\end{array}$ & $\begin{array}{l}346 \\
294 \\
302 \\
388 \\
346 \\
\end{array}$ & $\begin{array}{r}255 \\
255 \\
24 i \\
\cdots\end{array}$ & $\begin{array}{l}208 \\
175 \\
174 \\
220 \\
208 \\
\end{array}$ & $\begin{array}{r}150 \\
151 \\
141 \\
\cdots \\
\end{array}$ & $\begin{array}{r}6.2 \\
4.8 \\
14.3 \\
7.1 \\
9.0 \\
\end{array}$ & $\begin{array}{l}292 / 74 \\
226 / 58 \\
651 / 161 \\
342 / 82 \\
427 / 101 \\
\end{array}$ & $\begin{array}{l}320 \\
280 \\
160 \\
150 \\
470^{x} \\
\end{array}$ & $\begin{array}{l}42 \\
42 \\
47 \\
47 \\
44 \\
\end{array}$ & $\begin{array}{l}40 / 17 \\
18 / 6 \\
55 / 22 \\
21 / 6 \\
49 \% \\
\end{array}$ & $\begin{array}{c}42 / 19 \\
32 / 18 \\
94 / 74 \\
41 / 24 \\
146^{x} / 121^{x} \\
\end{array}$ & $\begin{array}{l}\cdots \\
\cdots \\
\cdots \\
\end{array}$ & \\
\hline $\begin{array}{l}11 \\
12 \\
13 \\
14 \\
15 \\
\end{array}$ & $\begin{array}{l}\text { Niger } \\
\text { Chad } \\
\text { Guinea-Bissau } \\
\text { Central African Rep. } \\
\text { Senegal } \\
\end{array}$ & $\begin{array}{l}320 \\
326 \\
315 \\
308 \\
313 \\
\end{array}$ & $\begin{array}{l}233 \\
228 \\
228 \\
228 \\
227 \\
\end{array}$ & $\begin{array}{l}191 \\
195 \\
188 \\
183 \\
180 \\
\end{array}$ & $\begin{array}{l}137 \\
134 \\
134 \\
134 \\
134 \\
\end{array}$ & $\begin{array}{l}6.3 \\
5.1 \\
0.9 \\
2.6 \\
6.6 \\
\end{array}$ & $\begin{array}{c}324 / 76 \\
228 / 52 \\
37 / 8 \\
117 / 27 \\
309 / 70 \\
\end{array}$ & $\begin{array}{l}250 \\
80^{x} \\
180 \\
260 \\
370 \\
\end{array}$ & $\begin{array}{l}44 \\
45 \\
45 \\
45 \\
45 \\
\end{array}$ & $\begin{array}{l}19 / 9 \\
40 / 11 \\
46 / 17 \\
53 / 29 \\
37 / 19 \\
\end{array}$ & $\begin{array}{c}37 / 20 \\
55 / 21 \\
81 / 40 \\
98 \times / 51^{x} \\
66 / 45 \\
\end{array}$ & $\begin{array}{l}\cdots \\
\cdots \\
\cdots\end{array}$ & $\dot{.}$ \\
\hline $\begin{array}{l}16 \\
17 \\
18 \\
19 \\
20 \\
\end{array}$ & $\begin{array}{l}\text { Mauritania } \\
\text { Liberia } \\
\text { Rwanda } \\
\text { Kampuchea } \\
\text { Yemen } \\
\end{array}$ & $\begin{array}{l}310 \\
303 \\
248 \\
218 \\
378 \\
\end{array}$ & $\begin{array}{l}225 \\
211 \\
210 \\
208 \\
204 \\
\end{array}$ & $\begin{array}{l}185 \\
180 \\
146 \\
146 \\
214 \\
\end{array}$ & $\begin{array}{l}129 \\
124 \\
124 \\
132 \\
123 \\
\end{array}$ & $\begin{array}{l}1.9 \\
2.3 \\
6.3 \\
7.5 \\
7.0 \\
\end{array}$ & $\begin{array}{r}98 / 22 \\
110 / 23 \\
323 / 68 \\
318 / 66 \\
339 / 69\end{array}$ & $\begin{array}{l}420 \\
470 \\
280 \\
550 \\
\end{array}$ & $\begin{array}{l}46 \\
51 \\
48 \\
48 \\
50\end{array}$ & $\begin{array}{c}4 / / 23 \\
47 / 23 \\
61 / 33 \\
85^{*} / 65 \\
27 / 3\end{array}$ & $\begin{array}{c}45^{x} / 29^{x} \\
82^{*} / 50^{*} \\
66 / 63 \\
100^{*} / 80^{*} \\
112 / 22\end{array}$ & $\begin{array}{l}\cdots \\
\cdots\end{array}$ & \\
\hline $\begin{array}{l}21 \\
22 \\
23 \\
24 \\
25 \\
\end{array}$ & $\begin{array}{l}\text { Yemen, Dem. } \\
\text { Bhutan } \\
\text { Nepal } \\
\text { Burundi } \\
\text { Bangladesh } \\
\end{array}$ & $\begin{array}{l}378 \\
297 \\
297 \\
258 \\
262 \\
\end{array}$ & $\begin{array}{l}204 \\
202 \\
202 \\
196 \\
193 \\
\end{array}$ & $\begin{array}{l}214 \\
186 \\
186 \\
152 \\
156 \\
\end{array}$ & $\begin{array}{l}123 \\
130 \\
130 \\
116 \\
121 \\
\end{array}$ & $\begin{array}{r}2.2 \\
1.4 \\
16.9 \\
4.9 \\
103.9 \\
\end{array}$ & $\begin{array}{c}104 / 21 \\
54 / 41 \\
677 / 137 \\
225 / 44 \\
4428 / 854 \\
\end{array}$ & $\begin{array}{l}530 \\
160 \\
160 \\
230 \\
150 \\
\end{array}$ & $\begin{array}{l}50 \\
48 \\
48 \\
48 \\
49 \\
\end{array}$ & $\begin{array}{c}59 / 25 \\
39 / 1 / 12 \\
43^{x / 26^{x}} \\
43 / 22 \\
\end{array}$ & $\begin{array}{c}96 / 35 \\
32 / 18 \\
80^{*} / 44^{*} \\
61 / 44 \\
70 / 50 \\
\end{array}$ & $\begin{array}{l}\cdots \\
\vdots \\
17 \\
\end{array}$ & \\
\hline $\begin{array}{l}26 \\
27 \\
28 \\
29 \\
\end{array}$ & $\begin{array}{l}\text { Benin } \\
\text { Sudan } \\
\text { Tanzania, U. Rep. of } \\
\text { Bolivia }\end{array}$ & $\begin{array}{l}310 \\
293 \\
248 \\
282\end{array}$ & $\begin{array}{l}189 \\
182 \\
179 \\
179 \\
\end{array}$ & $\begin{array}{l}185 \\
170 \\
146 \\
167 \\
\end{array}$ & $\begin{array}{l}112 \\
108 \\
107 \\
113 \\
\end{array}$ & $\begin{array}{r}4.2 \\
22.2 \\
23.3 \\
6.5 \\
\end{array}$ & $\begin{array}{c}213 / 40 \\
996 / 181 \\
1184 / 212 \\
284 / 51\end{array}$ & $\begin{array}{l}260 \\
300 \\
290 \\
470\end{array}$ & $\begin{array}{l}46 \\
50 \\
53 \\
53\end{array}$ & $\begin{array}{c}37 / 16 \\
33^{y} / 14^{y} \\
93^{y} / 188^{y} \\
84 / 65\end{array}$ & $\begin{array}{c}87 / 43 \\
57^{*} / 49^{*} \\
79^{*} / 81^{*} \\
96 / 85\end{array}$ & $\begin{array}{l}\cdots \\
\cdots\end{array}$ & \\
\hline \multirow[t]{2}{*}{$\begin{array}{l}30 \\
31 \\
32 \\
33 \\
\end{array}$} & $\begin{array}{l}\text { Nigeria } \\
\text { Haiti } \\
\text { Gabon } \\
\text { Uganda } \\
\end{array}$ & $\begin{array}{l}318 \\
294 \\
288 \\
224 \\
\end{array}$ & $\begin{array}{l}178 \\
176 \\
174 \\
174 \\
\end{array}$ & $\begin{array}{l}190 \\
197 \\
171 \\
133 \\
\end{array}$ & $\begin{array}{l}107 \\
119 \\
105 \\
105 \\
\end{array}$ & $\begin{array}{r}98.5 \\
6.8 \\
1.2 \\
16.0 \\
\end{array}$ & $\begin{array}{c}5015 / 895 \\
278 / 49 \\
43 / 7 \\
810 / 141 \\
\end{array}$ & $\begin{array}{r}800 \\
310 \\
3670 \\
230 \\
\end{array}$ & $\begin{array}{l}50 \\
54 \\
51 \\
51 \\
\end{array}$ & $\begin{array}{l}54 / 31 \\
40 / 35 \\
70 / 53 \\
70 / 45 \\
\end{array}$ & $\begin{array}{c}103 / 81 \\
83 / 72 \\
124 / 121 \\
66^{x} / 50^{x} \\
\end{array}$ & $\begin{array}{l}6 \\
\cdots \\
\cdots \\
\end{array}$ & 4 \\
\hline & $\begin{array}{l}\text { Hoh U5MR countries } \\
\text { (9-170) } \\
\text { Median }\end{array}$ & 251 & 125 & 156 & 85 & 15200 & $49840 T / 704 \pi$ & 770 & 57 & $68 / 50$ & $105 / 92$ & $\ldots$ & \\
\hline $\begin{array}{l}34 \\
35 \\
36 \\
37 \\
38 \\
\end{array}$ & $\begin{array}{l}\text { Pakistan } \\
\text { Zaire } \\
\text { Lao People's Dem. Rep. } \\
\text { Oman } \\
\text { Iran (Islamic Rep. of) }\end{array}$ & $\begin{array}{l}277 \\
251 \\
232 \\
378 \\
254 \\
\end{array}$ & $\begin{array}{l}170 \\
166 \\
166 \\
166 \\
\cdots \\
\end{array}$ & $\begin{array}{l}163 \\
148 \\
155 \\
214 \\
169 \\
\end{array}$ & $\begin{array}{l}111 \\
100 \\
113 \\
104\end{array}$ & $\begin{array}{r}102.9 \\
30.9 \\
4.2 \\
1.3 \\
45.9 \\
\end{array}$ & $\begin{array}{c}4211 / 716 \\
1394 / 232 \\
165 / 27 \\
58 / 10 \\
1801 / 286 \\
\end{array}$ & $\begin{array}{r}380 \\
170 \\
6730 \\
\quad . \\
\end{array}$ & $\begin{array}{l}52 \\
52 \\
52 \\
55 \\
59 \\
\end{array}$ & $\begin{array}{c}40 / 19 \\
79 / 45 \\
92 / 76 \\
47 y / 12^{y} \\
62 / 39 \\
\end{array}$ & $\begin{array}{c}66^{*} / 33^{*} \\
112 / 84 \\
101 / 79 \\
97 / 80 \\
122 / 101 \\
\end{array}$ & $\begin{array}{l}18 \\
\cdots \\
\cdots \\
\cdots\end{array}$ & $\begin{array}{l}5 \\
. \\
.\end{array}$ \\
\hline $\begin{array}{l}39 \\
40 \\
41 \\
42 \\
43 \\
\end{array}$ & $\begin{array}{l}\text { Cameroon } \\
\text { Togo } \\
\text { India } \\
\text { Cote d'lvoire } \\
\text { Ghana } \\
\end{array}$ & $\begin{array}{l}275 \\
305 \\
282 \\
320 \\
224 \\
\end{array}$ & $\begin{array}{l}158 \\
157 \\
154 \\
153 \\
150 \\
\end{array}$ & $\begin{array}{l}163 \\
182 \\
165 \\
200 \\
132 \\
\end{array}$ & $\begin{array}{r}96 \\
95 \\
101 \\
102 \\
91 \\
\end{array}$ & $\begin{array}{r}10.2 \\
3.1 \\
772.7 \\
10.2 \\
14.0 \\
\end{array}$ & $\begin{array}{c}435 / 69 \\
138 / 22 \\
22477 / 3455 \\
463 / 71 \\
663 / 99 \\
\end{array}$ & $\begin{array}{l}810 \\
230 \\
270 \\
660 \\
380 \\
\end{array}$ & $\begin{array}{l}53 \\
52 \\
57 \\
52 \\
54 \\
\end{array}$ & $\begin{array}{l}68 / 55 \\
53 / 28 \\
57 / 29 \\
53 / 31 \\
64 / 43 \\
\end{array}$ & $\begin{array}{r}116 / 97 \\
118 / 73 \\
107 / 76 \\
92 / 65 \\
75 / 59 \\
\end{array}$ & $\begin{array}{r}16 \\
9\end{array}$ & $\begin{array}{l}45 \\
61\end{array}$ \\
\hline $\begin{array}{l}44 \\
45 \\
46 \\
47 \\
48 \\
\end{array}$ & $\begin{array}{l}\text { Lesotho } \\
\text { Zambia } \\
\text { Egypt } \\
\text { Peru } \\
\text { Libyan Arab Jamahiriya }\end{array}$ & $\begin{array}{l}208 \\
228 \\
300 \\
233 \\
268 \\
\end{array}$ & $\begin{array}{l}140 \\
132 \\
131 \\
128 \\
125 \\
\end{array}$ & $\begin{array}{l}149 \\
135 \\
179 \\
142 \\
160 \\
\end{array}$ & $\begin{array}{r}102 \\
82 \\
88 \\
91 \\
85 \\
\end{array}$ & $\begin{array}{r}1.6 \\
6.9 \\
48.0 \\
20.2 \\
3.7 \\
\end{array}$ & $\begin{array}{c}65 / 9 \\
333 / 44 \\
1629 / 214 \\
709 / 91 \\
167 / 21 \\
\end{array}$ & $\begin{array}{r}470 \\
390 \\
610 \\
1010 \\
7170 \\
\end{array}$ & $\begin{array}{l}51 \\
53 \\
60 \\
61 \\
60 \\
\end{array}$ & $\begin{array}{l}62 / 84 \\
84 / 67 \\
59 / 30 \\
91 / 78 \\
81 / 50 \\
\end{array}$ & $\begin{array}{c}102 / 127 \\
106 / 96 \\
94 / 76 \\
125 / 120 \\
1 . \\
\end{array}$ & $\begin{array}{c}11 \\
17^{x} \\
7^{x} \\
. \\
\end{array}$ & $\begin{array}{l}6 ! \\
4 ! \\
6\end{array}$ \\
\hline $\begin{array}{l}49 \\
50 \\
51 \\
52 \\
53\end{array}$ & $\begin{array}{l}\text { Morocco } \\
\text { Indonesia } \\
\text { Congo } \\
\text { Kenya } \\
\text { Zimbabwe }\end{array}$ & $\begin{array}{l}265 \\
235 \\
241 \\
208 \\
182\end{array}$ & $\begin{array}{l}125 \\
122 \\
119 \\
118 \\
118\end{array}$ & $\begin{array}{l}163 \\
139 \\
143 \\
124 \\
110\end{array}$ & $\begin{array}{l}85 \\
76 \\
75 \\
74 \\
74\end{array}$ & $\begin{array}{r}22.5 \\
169.5 \\
1.8 \\
21.5 \\
9.1\end{array}$ & $\begin{array}{c}755 / 95 \\
5020 / 614 \\
80 / 10 \\
1182 / 139 \\
431 / 151\end{array}$ & $\begin{array}{r}560 \\
530 \\
1110 \\
290 \\
680\end{array}$ & $\begin{array}{l}60 \\
56 \\
48 \\
55 \\
57\end{array}$ & $\begin{array}{l}45 / 22 \\
83 / 65 \\
71 / 55 \\
70 / 49 \\
81 / 67\end{array}$ & $\begin{array}{c}98 / 63 \\
121 / 116 \\
97 / 91 \\
132 / 126\end{array}$ & $\begin{array}{l}14 \\
9\end{array}$ & $\begin{array}{l}4: \\
6 x\end{array}$ \\
\hline $\begin{array}{l}54 \\
55 \\
56 \\
57 \\
58 \\
\end{array}$ & $\begin{array}{l}\text { Honduras } \\
\text { Algeria } \\
\text { Tunisia } \\
\text { Guatemala } \\
\text { Saudi Arabia } \\
\end{array}$ & $\begin{array}{l}232 \\
270 \\
255 \\
230 \\
292 \\
\end{array}$ & $\begin{array}{l}112 \\
112 \\
106 \\
105 \\
105 \\
\end{array}$ & $\begin{array}{l}144 \\
168 \\
159 \\
125 \\
170 \\
\end{array}$ & $\begin{array}{l}71 \\
76 \\
74 \\
61 \\
74 \\
\end{array}$ & $\begin{array}{r}4.5 \\
22.4 \\
7.2 \\
8.2 \\
12.0 \\
\end{array}$ & $\begin{array}{l}184 / 21 \\
938 / 105 \\
226 / 24 \\
340 / 36 \\
495 / 52 \\
\end{array}$ & $\begin{array}{r}720 \\
2550 \\
1190 \\
1250 \\
8850 \\
\end{array}$ & $\begin{array}{l}62 \\
62 \\
62 \\
61 \\
63\end{array}$ & $\begin{array}{c}61 / 58 \\
63 / 37 \\
68 / 41 \\
63 / 47 \\
35^{x} / 12^{x} \\
\end{array}$ & $\begin{array}{c}103 / 102 \\
104 / 83 \\
127 / 108 \\
77 / 61 \\
\end{array}$ & $\begin{array}{l}\cdots \\
\cdots \\
\cdots\end{array}$ & \\
\hline $\begin{array}{l}59 \\
60 \\
61 \\
62 \\
63 \\
64\end{array}$ & $\begin{array}{l}\text { South Africa } \\
\text { Nicaragua } \\
\text { Turkey } \\
\text { lraa } \\
\text { Botswana } \\
\text { Viet Nam }\end{array}$ & $\begin{array}{l}192 \\
210 \\
258 \\
222 \\
174 \\
233\end{array}$ & $\begin{array}{r}101 \\
100 \\
99 \\
98 \\
96 \\
95\end{array}$ & $\begin{array}{l}135 \\
140 \\
190 \\
139 \\
119 \\
156\end{array}$ & $\begin{array}{l}75 \\
64 \\
79 \\
71 \\
69 \\
68\end{array}$ & $\begin{array}{r}33.2 \\
3.4 \\
50.3 \\
16.4 \\
1.1 \\
60.9\end{array}$ & $\begin{array}{c}1272 / 128 \\
145 / 14 \\
1486 / 147 \\
689 / 67 \\
57 / 5 \\
1835 / 175\end{array}$ & $\begin{array}{c}2010 \\
770 \\
1080 \\
3020 x \\
840\end{array}$ & $\begin{array}{l}55 \\
63 \\
64 \\
64 \\
56 \\
61\end{array}$ & $\begin{array}{c}\% \\
86^{x} / 62^{x} \\
90 / 87 \\
73 / 69 \\
88^{*} / 80^{\circ}\end{array}$ & $\begin{array}{c}1 \\
119 / 112 \\
108 / 92 \\
98 / 109 \\
107 / 94\end{array}$ & $\begin{array}{l}\cdots \\
12^{x} \\
\cdots\end{array}$ & 0 \\
\hline
\end{tabular}

Note: nations are listed in descending order of their 1986 under-five mortality rates (shown in bold type) 
TABLEAU 1: INDICATEURS DE BASE

\begin{tabular}{|c|c|c|c|c|c|c|c|c|c|c|c|c|c|}
\hline & & \multicolumn{2}{|c|}{$\begin{array}{l}\text { Taux } \\
\text { de martalité } \\
\text { des moins } \\
\text { de } 5 \text { ans }\end{array}$} & \multicolumn{2}{|c|}{$\begin{array}{c}\text { Taux } \\
\text { de mortalité } \\
\text { infantile } \\
\text { (moins d'un an) }\end{array}$} & \multirow{2}{*}{$\begin{array}{c}\text { Population } \\
\text { (millions } \\
\text { d'habitants) } \\
1990\end{array}$} & \multirow{2}{*}{$\begin{array}{c}\text { Nambre } \\
\text { annuel } \\
\text { de naissances } \\
\text { (milliers) } \\
1990\end{array}$} & \multirow[t]{2}{*}{$\begin{array}{c}\text { Nombre } \\
\text { annuel } \\
\text { te décés } \\
\text { des mons } \\
\text { te } 5 \text { ans } \\
\text { (militers) } \\
\text { i990 }\end{array}$} & \multirow{2}{*}{$\begin{array}{c}\text { PNB } \\
\text { par habitant } \\
\text { (dollars) } \\
1989\end{array}$} & \multirow[t]{2}{*}{$\begin{array}{l}\text { Espérance } \\
\text { de vie a la } \\
\text { naissance } \\
\text { (annees) } \\
\text { i990 }\end{array}$} & \multirow[t]{2}{*}{$\begin{array}{c}\text { Taux } \\
\text { d'alpha. } \\
\text { bétisation } \\
\text { des aduftes } \\
(\%) \\
1990\end{array}$} & \multirow[t]{2}{*}{$\begin{array}{c}\text { Taux } \\
\text { dinscríption } \\
\text { à l'école } \\
\text { prmaire du } \\
\text { groupe óage } \\
\text { pertinent (\%) } \\
\text { \{986-1989 }\end{array}$} & \multirow[t]{2}{*}{$\begin{array}{l}\text { Aépartitio } \\
\text { do revenu } \\
\text { les menages } \\
1976-198 \\
\text { Ies } 40 \% \text { les } \\
\text { les plus les } \\
\text { pauvres }\end{array}$} \\
\hline & & 1960 & 1990 & 1960 & 1990 & & & & & & & & \\
\hline & $\begin{array}{l}\text { Pay a tMM5 trda dteve } \\
\text { (ouperieur a 140) } \\
\text { Modlane }\end{array}$ & 302 & 189 & 184 & 116 & $1536 \mathrm{~T}$ & $58458 \mathrm{~T}$ & $9774 T$ & 290 & 50 & 35 & 63 & . . \\
\hline $\begin{array}{l}1 \\
2 \\
3 \\
4 \\
5\end{array}$ & $\begin{array}{l}\text { Mozambique } \\
\text { Afghanistan } \\
\text { Angola } \\
\text { Mali } \\
\text { Sierra Leone }\end{array}$ & $\begin{array}{l}331 \\
381 \\
344 \\
369 \\
385\end{array}$ & $\begin{array}{l}297 \\
292 \\
292 \\
284 \\
257\end{array}$ & $\begin{array}{l}190 \\
215 \\
208 \\
210 \\
219\end{array}$ & $\begin{array}{l}173 \\
167 \\
173 \\
164 \\
149\end{array}$ & $\begin{array}{r}15.7 \\
16.6 \\
10.0 \\
9.2 \\
4.2\end{array}$ & $\begin{array}{l}699 \\
888 \\
472 \\
472 \\
201\end{array}$ & $\begin{array}{r}208 \\
260 \\
138 \\
134 \\
52\end{array}$ & $\begin{array}{c}80 \\
280^{x} \\
610 \\
270 \\
220\end{array}$ & $\begin{array}{l}48 \\
43 \\
46 \\
45 \\
42\end{array}$ & $\begin{array}{l}33 \\
29 \\
42 \\
32 \\
21\end{array}$ & $\begin{array}{l}68 \\
25 \\
93 \\
23 \\
53\end{array}$ & 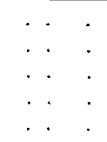 \\
\hline $\begin{array}{r}6 \\
7 \\
8 \\
9 \\
10\end{array}$ & $\begin{array}{l}\text { Malawi } \\
\text { Guinée-Bissau } \\
\text { Guinée } \\
\text { Burkina Faso } \\
\text { Niger }\end{array}$ & $\begin{array}{l}366 \\
336 \\
336 \\
363 \\
321\end{array}$ & $\begin{array}{l}253 \\
246 \\
237 \\
228 \\
221\end{array}$ & $\begin{array}{l}207 \\
200 \\
203 \\
205 \\
191\end{array}$ & $\begin{array}{l}144 \\
146 \\
140 \\
133 \\
130\end{array}$ & $\begin{array}{l}8.8 \\
1.0 \\
5.8 \\
9.0 \\
7.7\end{array}$ & $\begin{array}{r}494 \\
41 \\
294 \\
426 \\
401\end{array}$ & $\begin{array}{r}125 \\
10 \\
70 \\
97 \\
89\end{array}$ & $\begin{array}{l}180 \\
180 \\
430 \\
320 \\
290\end{array}$ & $\begin{array}{l}48 \\
43 \\
44 \\
48 \\
46\end{array}$ & $\begin{array}{l}\cdots \\
24 \\
18 \\
28\end{array}$ & $\begin{array}{l}72 \\
53 \\
30 \\
32 \\
30\end{array}$ & $\begin{array}{ll}\cdot & \cdot \\
\cdot & : \\
\cdot & \cdot \\
\cdot & \cdot \\
\cdot & \cdot\end{array}$ \\
\hline $\begin{array}{l}11 \\
12 \\
13 \\
14 \\
15\end{array}$ & $\begin{array}{l}\text { Ethiopie } \\
\text { Tchad } \\
\text { Somalie } \\
\text { Mauritanie } \\
\text { Libéria }\end{array}$ & $\begin{array}{l}294 \\
325 \\
294 \\
321 \\
310 \\
\end{array}$ & $\begin{array}{l}220 \\
216 \\
215 \\
214 \\
205 \\
\end{array}$ & $\begin{array}{l}175 \\
195 \\
175 \\
191 \\
184 \\
\end{array}$ & $\begin{array}{l}130 \\
127 \\
127 \\
122 \\
134 \\
\end{array}$ & $\begin{array}{r}49.2 \\
5.7 \\
7.5 \\
2.0 \\
2.6 \\
\end{array}$ & $\begin{array}{r}2424 \\
249 \\
360 \\
94 \\
122 \\
\end{array}$ & $\begin{array}{r}534 \\
54 \\
77 \\
20 \\
25\end{array}$ & $\begin{array}{l}120 \\
190 \\
170 \\
500 \\
450^{x}\end{array}$ & $\begin{array}{l}46 \\
47 \\
46 \\
47 \\
54\end{array}$ & $\begin{array}{l}30 \\
17^{x} \\
34 \\
40 \\
\end{array}$ & $\begin{array}{l}36 \\
51 \\
15 \\
52 \\
34 \\
\end{array}$ & $\begin{array}{ll}\cdot & \cdot \\
\cdot & \cdot \\
\cdot & \cdot \\
\cdot & \cdot \\
\cdot & \cdot \\
& \cdot \\
\end{array}$ \\
\hline $\begin{array}{l}16 \\
17 \\
18 \\
19 \\
20\end{array}$ & $\begin{array}{l}\text { Rwanda } \\
\text { Cambodge } \\
\text { Burundi } \\
\text { Bhoutan } \\
\text { Népal }\end{array}$ & $\begin{array}{l}248 \\
218 \\
260 \\
298 \\
298 \\
\end{array}$ & $\begin{array}{l}198 \\
193 \\
192 \\
189 \\
189 \\
\end{array}$ & $\begin{array}{l}146 \\
146 \\
153 \\
187 \\
187 \\
\end{array}$ & $\begin{array}{l}117 \\
123 \\
115 \\
123 \\
123 \\
\end{array}$ & $\begin{array}{r}7.2 \\
8.2 \\
5.5 \\
1.5 \\
19.1 \\
\end{array}$ & $\begin{array}{r}368 \\
322 \\
261 \\
58 \\
725 \\
\end{array}$ & $\begin{array}{r}73 \\
62 \\
50 \\
11 \\
137 \\
\end{array}$ & $\begin{array}{l}320 \\
220 \\
190^{x} \\
180\end{array}$ & $\begin{array}{l}50 \\
50 \\
49 \\
49 \\
52\end{array}$ & $\begin{array}{l}50 \\
35 \\
50 \\
38 \\
26 \\
\end{array}$ & $\begin{array}{l}67 \\
59 \\
26 \\
86\end{array}$ & $\begin{array}{ll}\cdot & \\
\cdot & - \\
\cdot & \cdot \\
. & \cdot \\
13^{x} & 5 !\end{array}$ \\
\hline $\begin{array}{l}21 \\
22 \\
23 \\
24 \\
25\end{array}$ & $\begin{array}{l}\text { Yémen } \\
\text { Sénégai } \\
\text { Bangladesh } \\
\text { Madagascar } \\
\text { Soudan } \\
\end{array}$ & $\begin{array}{l}378 \\
299 \\
262 \\
364 \\
292 \\
\end{array}$ & $\begin{array}{l}187 \\
185 \\
180 \\
176 \\
172 \\
\end{array}$ & $\begin{array}{l}214 \\
172 \\
156 \\
220 \\
170 \\
\end{array}$ & $\begin{array}{r}114 \\
84 \\
114 \\
115 \\
104 \\
\end{array}$ & $\begin{array}{r}11.7 \\
7.3 \\
115.6 \\
12.0 \\
25.2 \\
\end{array}$ & $\begin{array}{r}602 \\
328 \\
4796 \\
547 \\
1111 \\
\end{array}$ & $\begin{array}{r}113 \\
61 \\
866 \\
96 \\
191 \\
\end{array}$ & $\begin{array}{l}650 \\
650 \\
180 \\
230 \\
420^{x} \\
\end{array}$ & $\begin{array}{l}51 \\
48 \\
52 \\
55 \\
51\end{array}$ & $\begin{array}{l}32^{y} \\
38 \\
35 \\
80 \\
27 \\
\end{array}$ & $\begin{array}{l}87 \\
59 \\
70 \\
97 \\
49\end{array}$ & $\begin{array}{ll}. & \\
24 & 3 \\
. & \\
. & \\
\end{array}$ \\
\hline $\begin{array}{l}26 \\
27 \\
28 \\
29 \\
30\end{array}$ & $\begin{array}{l}\text { Tanzanie, Rép.-Unie de } \\
\text { Rép. centratricaine } \\
\text { Namibie } \\
\text { Nigéria } \\
\text { Gabon }\end{array}$ & $\begin{array}{r}249 \\
08 \\
263 \\
316 \\
287 \\
\end{array}$ & $\begin{array}{l}170 \\
169 \\
167 \\
167 \\
164 \\
\end{array}$ & $\begin{array}{l}147 \\
183 \\
155 \\
190 \\
171 \\
\end{array}$ & $\begin{array}{r}102 \\
100 \\
102 \\
101 \\
99 \\
\end{array}$ & $\begin{array}{r}27.3 \\
3.0 \\
1.8 \\
108.5 \\
1.2 \\
\end{array}$ & $\begin{array}{r}1387 \\
138 \\
76 \\
5183 \\
49 \\
\end{array}$ & $\begin{array}{r}235 \\
23 \\
13 \\
865 \\
8\end{array}$ & $\begin{array}{r}130 \\
390 \\
1030 \\
250 \\
2960 \\
\end{array}$ & $\begin{array}{l}54 \\
50 \\
58 \\
52 \\
53\end{array}$ & $\begin{array}{l}91 y \\
38 \\
51 \\
61\end{array}$ & $\begin{array}{l}66 \\
67 \\
66 \\
.\end{array}$ & $\begin{array}{ll}. & \cdot \\
. & . \\
. & . \\
. & . \\
. & . \\
. & .\end{array}$ \\
\hline $\begin{array}{l}31 \\
32 \\
33 \\
34 \\
35\end{array}$ & $\begin{array}{l}\text { Ouganda } \\
\text { Bolivie } \\
\text { Pakistan } \\
\text { Rép.dém.pop.lao } \\
\text { Cameroun }\end{array}$ & $\begin{array}{l}223 \\
282 \\
276 \\
233 \\
275\end{array}$ & $\begin{array}{l}164 \\
160 \\
158 \\
152 \\
148\end{array}$ & $\begin{array}{l}133 \\
167 \\
163 \\
155 \\
163\end{array}$ & $\begin{array}{r}99 \\
102 \\
104 \\
104 \\
90\end{array}$ & $\begin{array}{r}18.8 \\
7.3 \\
122.6 \\
4.1 \\
11.8 \\
\end{array}$ & $\begin{array}{r}985 \\
309 \\
5451 \\
187 \\
566\end{array}$ & $\begin{array}{r}161 \\
50 \\
863 \\
28 \\
83\end{array}$ & $\begin{array}{r}250 \\
620 \\
370 \\
180 \\
1000\end{array}$ & $\begin{array}{l}52 \\
55 \\
58 \\
50 \\
54\end{array}$ & $\begin{array}{l}48 \\
78 \\
35 \\
54\end{array}$ & $\begin{array}{r}77 \\
91 \\
40 \\
110 \\
1+1\end{array}$ & $\begin{array}{ll}12 & 5 \\
19 & 4 \\
. & . \\
. & \end{array}$ \\
\hline \multirow[t]{2}{*}{$\begin{array}{l}36 \\
37 \\
38\end{array}$} & $\begin{array}{l}\text { Bénin } \\
\text { Togo } \\
\text { Inde }\end{array}$ & $\begin{array}{l}310 \\
305 \\
282\end{array}$ & $\begin{array}{l}147 \\
147 \\
142\end{array}$ & $\begin{array}{l}185 \\
182 \\
165\end{array}$ & $\begin{array}{l}88 \\
90 \\
94\end{array}$ & $\begin{array}{r}4.6 \\
3.5 \\
853.1 \\
\end{array}$ & $\begin{array}{r}229 \\
158 \\
26985\end{array}$ & $\begin{array}{r}34 \\
23 \\
3835 \\
\end{array}$ & $\begin{array}{l}380 \\
390 \\
340\end{array}$ & $\begin{array}{l}47 \\
54 \\
59\end{array}$ & $\begin{array}{l}23 \\
43 \\
48\end{array}$ & $\begin{array}{r}63 \\
101 \\
99\end{array}$ & $\dot{20} 4$ \\
\hline & $\begin{array}{l}\text { Paye a TMM5 eleve } \\
(71-140) \\
\text { Mediane }\end{array}$ & 229 & 90 & 143 & 66 & 7931 & $25837 T$ & $2510 \mathrm{~T}$ & 885 & 62 & 68 & 97 & 12 \\
\hline $\begin{array}{l}39 \\
40 \\
41 \\
42 \\
43\end{array}$ & $\begin{array}{l}\text { Ghana } \\
\text { Cóte d'lvoire } \\
\text { Haïti } \\
\text { Zaïre } \\
\text { Lesotho } \\
\end{array}$ & $\begin{array}{l}224 \\
264 \\
270 \\
269 \\
208 \\
\end{array}$ & $\begin{array}{l}140 \\
136 \\
130 \\
130 \\
129 \\
\end{array}$ & $\begin{array}{l}132 \\
165 \\
182 \\
158 \\
149 \\
\end{array}$ & $\begin{array}{l}86 \\
92 \\
92 \\
79 \\
95 \\
\end{array}$ & $\begin{array}{r}15.0 \\
12.0 \\
6.5 \\
35.6 \\
1.8 \\
\end{array}$ & $\begin{array}{r}665 \\
603 \\
233 \\
1626 \\
72 \\
\end{array}$ & $\begin{array}{r}93 \\
82 \\
30 \\
211 \\
9 \\
\end{array}$ & $\begin{array}{l}390 \\
790 \\
360 \\
260 \\
470 \\
\end{array}$ & $\begin{array}{l}55 \\
53 \\
56 \\
53 \\
57\end{array}$ & $\begin{array}{l}60 \\
54 \\
53 \\
72 \\
.\end{array}$ & $\begin{array}{r}73 \\
70 \\
83 \\
76 \\
112 \\
\end{array}$ & $\begin{array}{cc}17 & 4 \\
13 & 5 \\
6^{*} & 4 \\
. & . \\
. & . \\
\end{array}$ \\
\hline $\begin{array}{l}44 \\
45 \\
46 \\
47 \\
48\end{array}$ & $\begin{array}{l}\text { Zambie } \\
\text { Pérou } \\
\text { Jamahiriya arabe libyenne } \\
\text { Maroc } \\
\text { Congo } \\
\end{array}$ & $\begin{array}{l}228 \\
233 \\
269 \\
265 \\
241 \\
\end{array}$ & $\begin{array}{l}122 \\
116 \\
112 \\
112 \\
110 \\
\end{array}$ & $\begin{array}{l}135 \\
142 \\
160 \\
163 \\
143 \\
\end{array}$ & $\begin{array}{l}76 \\
82 \\
75 \\
75 \\
69 \\
\end{array}$ & $\begin{array}{r}8.5 \\
21.6 \\
4.5 \\
25.1 \\
2.3 \\
\end{array}$ & $\begin{array}{l}433 \\
647 \\
199 \\
858 \\
105 \\
\end{array}$ & $\begin{array}{l}53 \\
75 \\
22 \\
96 \\
12 \\
\end{array}$ & $\begin{array}{r}390 \\
1010 \\
5310 \\
880 \\
940 \\
\end{array}$ & $\begin{array}{l}54 \\
63 \\
62 \\
62 \\
54 \\
\end{array}$ & $\begin{array}{l}73 \\
85 \\
64 \\
50 \\
57 \\
\end{array}$ & $\begin{array}{r}97 \\
122 \\
67 \\
.\end{array}$ & $\begin{array}{ll}11^{x} & 6 \\
13 & 5 \\
23 & 5 \\
. & \end{array}$ \\
\hline $\begin{array}{l}49 \\
50 \\
51 \\
52 \\
53\end{array}$ & $\begin{array}{l}\text { Kenya } \\
\text { Algérie } \\
\text { Indonésie } \\
\text { Guatemala } \\
\text { Arabie saoudite }\end{array}$ & $\begin{array}{l}208 \\
270 \\
225 \\
230 \\
292\end{array}$ & $\begin{array}{r}108 \\
98 \\
97 \\
94 \\
91\end{array}$ & $\begin{array}{l}124 \\
168 \\
139 \\
125 \\
170\end{array}$ & $\begin{array}{l}68 \\
68 \\
71 \\
54 \\
65\end{array}$ & $\begin{array}{r}24.0 \\
25.0 \\
184.3 \\
9.2 \\
14.1\end{array}$ & $\begin{array}{r}1132 \\
877 \\
5091 \\
367 \\
594\end{array}$ & $\begin{array}{r}122 \\
86 \\
494 \\
34 \\
54\end{array}$ & $\begin{array}{r}360 \\
2230 \\
500 \\
910 \\
6020\end{array}$ & $\begin{array}{l}60 \\
65 \\
61 \\
63 \\
65\end{array}$ & $\begin{array}{l}69 \\
57 \\
77 \\
55 \\
62\end{array}$ & $\begin{array}{r}93 \\
96 \\
119 \\
77 \\
71\end{array}$ & $\begin{array}{cc}9^{x} & f \\
21 & \vdots \\
14 & \vdots \\
. & \end{array}$ \\
\hline $\begin{array}{l}54 \\
55 \\
56 \\
57 \\
58\end{array}$ & $\begin{array}{l}\text { Afrique du Sud } \\
\text { Myanmar } \\
\text { El Salvador } \\
\text { Zimbabwe } \\
\text { Iraq }\end{array}$ & $\begin{array}{l}192 \\
230 \\
207 \\
181 \\
222\end{array}$ & $\begin{array}{l}88 \\
88 \\
87 \\
87 \\
86\end{array}$ & $\begin{array}{l}135 \\
153 \\
143 \\
110 \\
139\end{array}$ & $\begin{array}{l}67 \\
65 \\
59 \\
61 \\
63\end{array}$ & $\begin{array}{r}35.3 \\
41.7 \\
5.3 \\
9.7 \\
18.9 \\
\end{array}$ & $\begin{array}{r}1108 \\
1252 \\
191 \\
399 \\
789\end{array}$ & $\begin{array}{r}98 \\
111 \\
17 \\
35 \\
68\end{array}$ & $\begin{array}{c}2470 \\
220^{x} \\
1070 \\
650 \\
2340^{x}\end{array}$ & $\begin{array}{l}62 \\
61 \\
64 \\
60 \\
65\end{array}$ & $\begin{array}{l}81 \\
73 \\
67 \\
60\end{array}$ & $\begin{array}{r}103 \\
80 \\
128 \\
96\end{array}$ & 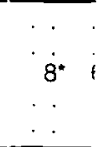 \\
\hline $\begin{array}{l}59 \\
60 \\
61 \\
62 \\
63\end{array}$ & $\begin{array}{l}\text { Egypte } \\
\text { Botswana } \\
\text { Turquie } \\
\text { Mongolie } \\
\text { Honduras }\end{array}$ & $\begin{array}{l}301 \\
173 \\
258 \\
185 \\
232\end{array}$ & $\begin{array}{l}85 \\
85 \\
80 \\
84 \\
84\end{array}$ & $\begin{array}{l}179 \\
119 \\
190 \\
128 \\
144\end{array}$ & $\begin{array}{l}61 \\
63 \\
69 \\
64 \\
63\end{array}$ & $\begin{array}{r}52.4 \\
1.3 \\
55.9 \\
2.2 \\
5.1\end{array}$ & $\begin{array}{r}1727 \\
61 \\
1579 \\
77 \\
198\end{array}$ & $\begin{array}{r}148 \\
5 \\
134 \\
7 \\
17\end{array}$ & $\begin{array}{c}640 \\
1600 \\
1370 \\
780^{x} \\
900\end{array}$ & $\begin{array}{l}60 \\
60 \\
65 \\
63 \\
65\end{array}$ & $\begin{array}{l}48 \\
74 \\
81 \\
73\end{array}$ & $\begin{array}{r}90 \\
117 \\
117 \\
102 \\
106\end{array}$ & $\begin{array}{c}21^{*} \\
9 \\
11^{*} \\
12^{*}\end{array}$ \\
\hline
\end{tabular}

Note : Les pays sont énumérés par ordre décroissant de taux de mortalité des moins de 5 ans pour 1990 (en gras). 


\begin{tabular}{|c|c|c|c|c|c|c|c|c|c|}
\hline & & \multirow{2}{*}{$\begin{array}{c}\text { \% } \\
\text { of intants } \\
\text { with low } \\
\text { birth- } \\
\text { weight } \\
1982-85\end{array}$} & \multicolumn{3}{|c|}{$\begin{array}{c}\text { \% of } \\
\text { mothers } \\
\text { breast-feeding } \\
1980-86\end{array}$} & \multirow{2}{*}{$\begin{array}{l}\text { \%o of children under } \\
\text { five suffering trom } \\
\text { mild-moderate/severe } \\
\text { matnutrition } \\
1980-86\end{array}$} & \multirow{2}{*}{$\begin{array}{l}\text { Prevatence of } \\
\text { wasting aged } \\
12-23 \text { months } \\
\text { (\% of age group) } \\
1980-86\end{array}$} & \multirow{2}{*}{$\begin{array}{l}\text { Average index } \\
\text { of tood } \\
\text { production } \\
\text { per capita } \\
(1979-81=100) \\
1983-85\end{array}$} & \multirow{2}{*}{$\begin{array}{r}\text { Dail } \\
\text { per ca } \\
\text { calorie s } \\
\text { as \% } \\
\text { requiren } \\
198\end{array}$} \\
\hline & & & $\begin{array}{c}3 \\
\text { months }\end{array}$ & $\begin{array}{c}6 \\
\text { months }\end{array}$ & $\begin{array}{c}12 \\
\text { months }\end{array}$ & & & & \\
\hline & $\begin{array}{l}\text { Very high U5MA } \\
\text { countrios (over 170) } \\
\text { Modian }\end{array}$ & 15 & 95 & 90 & 70 & $31 / 7$ & 21 & 106 & 9: \\
\hline $\begin{array}{l}1 \\
2 \\
3 \\
4 \\
5\end{array}$ & $\begin{array}{l}\text { Afghanistan } \\
\text { Mali } \\
\text { Sierra Leone } \\
\text { Malawi } \\
\text { Ethiopia }\end{array}$ & $\begin{array}{l}17^{*} \\
13 \\
14 \\
10 \\
13\end{array}$ & $\begin{array}{l}20 \\
98^{\circ} \\
\cdots \\
\cdots\end{array}$ & $\begin{array}{c}6^{*} \\
\dot{9} 4^{y} \\
\dot{9} \dot{7 y}^{y}\end{array}$ & $\begin{array}{l}5 " \\
83^{\prime \prime} \\
96^{*} \\
95^{y}\end{array}$ & $\begin{array}{l}20^{*} / \% \\
24^{\circ} / 3^{*} \\
30^{\circ} \% \\
60^{\circ} / 10^{\circ}\end{array}$ & $\begin{array}{l}26 \\
36^{*} \\
28 \\
36^{*}\end{array}$ & $\begin{array}{r}104 \\
114 \\
108 \\
105 \\
97\end{array}$ & $\begin{array}{l}9 c \\
6 c \\
8 c \\
9 c \\
9\end{array}$ \\
\hline $\begin{array}{r}6 \\
7 \\
8 \\
9 \\
10 \\
\end{array}$ & $\begin{array}{l}\text { Guinea } \\
\text { Somalia } \\
\text { Mozambique } \\
\text { Burkina Faso } \\
\text { Angola }\end{array}$ & $\begin{array}{l}18 \\
15 * \\
21 \\
19\end{array}$ & $\begin{array}{l}100^{*} \\
92^{y} \\
\cdots \\
96^{x}\end{array}$ & $\begin{array}{l}70^{*} \\
78^{y} \\
\cdots \\
\cdots \\
\cdots \\
\end{array}$ & $\begin{array}{l}40^{*} \\
54^{y} \\
\cdots \\
\cdots \\
\cdots\end{array}$ & $\begin{array}{l}16 \% \\
. \% \\
. \% \\
\%\end{array}$ & ijx & $\begin{array}{r}102 \\
102 \\
98 \\
114 \\
102 \\
\end{array}$ & $\begin{array}{l}88 \\
91 \\
68 \\
81 \\
86\end{array}$ \\
\hline $\begin{array}{l}11 \\
12 \\
13 \\
14 \\
15 \\
\end{array}$ & $\begin{array}{l}\text { Niger } \\
\text { Chad } \\
\text { Guinea-Bissau } \\
\text { Central African Rep. } \\
\text { Senegal }\end{array}$ & $\begin{array}{l}20 \\
11 \\
15 \\
23 \\
10\end{array}$ & $\begin{array}{c}90^{\circ} \\
100^{\circ} \\
\dot{94}\end{array}$ & $\begin{array}{c}80^{*} \\
100^{\circ} \\
\dot{94} \\
\end{array}$ & $\begin{array}{l}60 " \\
98 . \\
82 \\
\end{array}$ & $\begin{array}{l}17^{*} / 9^{*} \\
\% \\
1 \% \\
20 \%\end{array}$ & $\begin{array}{l}21 \\
\cdots \\
20\end{array}$ & $\begin{array}{r}96 \\
106 \\
105 \\
105\end{array}$ & $\begin{array}{r}9 i \\
7 \mathfrak{1} \\
10: \\
96 \\
10:\end{array}$ \\
\hline $\begin{array}{l}16 \\
17 \\
18 \\
19 \\
20 \\
\end{array}$ & $\begin{array}{l}\text { Mauritania } \\
\text { Liberia } \\
\text { Rwanda } \\
\text { Kampuchea } \\
\text { Yemen } \\
\end{array}$ & $\begin{array}{l}10 \\
17 \\
9\end{array}$ & $\begin{array}{r}96^{*} \\
80^{*} \\
100^{*} \\
80^{\times} \\
\end{array}$ & $\begin{array}{l}92^{*} \\
24^{*} \\
93^{*} \\
76^{x} \\
\end{array}$ & $\begin{array}{r}70^{\circ} \\
99^{\circ} \\
79^{*} \\
55^{x} \\
\end{array}$ & $\begin{array}{l}30^{*} / 10^{*} \\
31^{*} / 4^{*} \\
29^{*} / 8^{*} \\
32^{*} / 5^{*} \\
54^{x} / 4^{x} \\
\end{array}$ & $\begin{array}{l}j \\
23 \\
17 x\end{array}$ & $\begin{array}{r}94 \\
114 \\
106 \\
153 \\
112 \\
\end{array}$ & $\begin{array}{r}9 i \\
10 i \\
8 i \\
8 i \\
9 i \\
\end{array}$ \\
\hline $\begin{array}{l}21 \\
22 \\
23 \\
24 \\
25 \\
\end{array}$ & $\begin{array}{l}\text { Yemen, Dem. } \\
\text { Bhutan } \\
\text { Nepal } \\
\text { Bunundi } \\
\text { Bangladesh } \\
\end{array}$ & $\begin{array}{l}12 \\
\cdots \\
14 \\
50\end{array}$ & $\begin{array}{l}80^{*} \\
99 x \\
98^{x}\end{array}$ & $\begin{array}{l}60^{*} \\
99 \times \\
95 \cdot \\
97^{x}\end{array}$ & $\begin{array}{l}55^{*} \\
977^{\circ} \\
90^{\circ} \\
89^{*}\end{array}$ & $\begin{array}{c}32^{\circ} / 8^{* \prime} \\
33 / 6 \\
50^{\prime} / / \pi \\
30 / 5 \\
60^{\circ} / 21^{*}\end{array}$ & $\begin{array}{l}36^{x} \\
27^{x} \\
36 \\
21\end{array}$ & $\begin{array}{l}100 \\
110 \\
116 \\
106 \\
110\end{array}$ & $\begin{array}{l}9: \\
\dot{8} \\
9 \\
98\end{array}$ \\
\hline $\begin{array}{l}26 \\
27 \\
23 \\
20\end{array}$ & $\begin{array}{l}\text { Benin } \\
\text { Sudan } \\
\text { Tanzania, U. Rep. of } \\
\text { Bolivia }\end{array}$ & $\begin{array}{l}10 \\
15 \\
14 \\
13^{*}\end{array}$ & $\begin{array}{c}95^{*} \\
91^{*} \\
100^{*} \\
93^{x}\end{array}$ & $\begin{array}{l}90^{*} \\
86^{x} \\
90^{*} \\
91^{x}\end{array}$ & $\begin{array}{l}75^{\circ} \\
72^{x} \\
70^{\circ} \\
48^{x}\end{array}$ & $\begin{array}{l}33^{\circ} / 8^{*} \\
43^{*} / 7^{*} \\
49^{\circ} / 3^{\prime}\end{array}$ & $\begin{array}{l}14 \\
17 \\
\cdots\end{array}$ & $\begin{array}{l}121 \\
103 \\
108 \\
101\end{array}$ & $\begin{array}{l}9 \\
\alpha \\
9 \\
8\end{array}$ \\
\hline \multirow[t]{2}{*}{$\begin{array}{l}30 \\
31 \\
32 \\
33 \\
\end{array}$} & $\begin{array}{l}\text { Nigeria } \\
\text { Haiti } \\
\text { Gabon } \\
\text { Uganda }\end{array}$ & $\begin{array}{l}25 \\
17 \\
16 \\
10 \\
\end{array}$ & $\begin{array}{l}99^{*} \\
90^{y} \\
85^{*}\end{array}$ & $\begin{array}{l}80^{*} \\
71^{\prime} \\
70^{\circ}\end{array}$ & $\begin{array}{l}60^{\circ} \\
29^{\prime \prime} \\
20^{\circ}\end{array}$ & $\begin{array}{l}24 / . \\
65^{\circ} / 5^{\circ} \\
15 \% / 4 y\end{array}$ & $\begin{array}{l}16^{*} \\
18^{y} \\
\cdots \\
\cdots\end{array}$ & $\begin{array}{r}109 \\
104 \\
125 \\
\end{array}$ & $\begin{array}{r}9 \\
7 \\
12 \\
10\end{array}$ \\
\hline & $\begin{array}{l}\text { High U5MA countrios } \\
\text { (95-170) } \\
\text { Modian }\end{array}$ & 13 & 95 & 90 & $71^{n+w}$ & $33 / 5$ & $14 \cdots$ & 109 & 10 \\
\hline $\begin{array}{l}34 \\
35 \\
36 \\
37 \\
38 \\
\end{array}$ & $\begin{array}{l}\text { Pakistan } \\
\text { Zaire } \\
\text { Lao People's Dem. Rep. } \\
\text { Oman } \\
\text { Iran (Islamic Rep. of) }\end{array}$ & $\begin{array}{l}27 \\
20^{*} \\
15 \\
14 \\
10^{*} \\
\end{array}$ & $\begin{array}{c}78^{*} \\
100^{x} \\
\cdots \\
\cdots \\
\end{array}$ & $\begin{array}{c}73^{*} \\
100^{x} \\
\cdots \\
\cdots \\
\cdots\end{array}$ & $\begin{array}{l}67^{*} \\
85^{x} \\
\cdots \\
\cdots \\
\cdots\end{array}$ & $\begin{array}{l}60^{*} / 10^{*} \\
15 \% / 5^{*} \\
38^{*} \% \\
\% \\
\% \\
\end{array}$ & $\begin{array}{l}14 \\
\cdots \\
\cdots \\
\cdots\end{array}$ & $\begin{array}{r}114 \\
113 \\
129 \\
109 \\
\end{array}$ & $\begin{array}{r}9 \\
9 \\
9 \\
9 \\
11 \ell\end{array}$ \\
\hline $\begin{array}{l}39 \\
40 \\
41 \\
42 \\
43\end{array}$ & $\begin{array}{l}\text { Cameroon } \\
\text { Togo } \\
\text { India } \\
\text { Cote d'lvoire } \\
\text { Ghana }\end{array}$ & $\begin{array}{l}13 \\
20 \\
30 \\
14 \\
17^{*}\end{array}$ & $\begin{array}{l}\cdots \\
933^{\circ} \\
100^{\circ}\end{array}$ & $\begin{array}{l}98^{x} \\
99^{x} \\
90^{*} \\
70^{*}\end{array}$ & $\begin{array}{l}97^{x} \\
90^{x} \\
50^{\circ} \\
25^{*}\end{array}$ & $\begin{array}{l}\% \\
33^{\circ} / 5^{*} \\
23^{*} / \pi^{*}\end{array}$ & $\begin{array}{l}37 \\
37 \\
21 * \\
28\end{array}$ & $\begin{array}{l}107 \\
103 \\
120 \\
115 \\
118\end{array}$ & $\begin{array}{r}8 \\
9 \\
9 \\
90 \\
70 \\
78\end{array}$ \\
\hline $\begin{array}{l}44 \\
45 \\
46 \\
47 \\
48 \\
\end{array}$ & $\begin{array}{l}\text { Lesotho } \\
\text { Zambia } \\
\text { Egypt } \\
\text { Peru } \\
\text { Libyan Arab Jamahiriya }\end{array}$ & $\begin{array}{l}10 \\
7 \\
7 \\
9 \\
5\end{array}$ & $80^{\circ}$ & $\begin{array}{l}87^{*} \\
\dot{9 i y} \\
67^{*}\end{array}$ & $\begin{array}{l}93^{\circ} \\
84^{y} \\
37^{*}\end{array}$ & $\begin{array}{l}1 \% \\
48 \% \% \\
38 \%\end{array}$ & $\begin{array}{l}7 \\
\therefore \\
\therefore \\
\cdots \\
\end{array}$ & $\begin{array}{r}93 \\
107 \\
115 \\
111 \\
\cdots \\
\end{array}$ & $\begin{array}{r}10 \\
8 \\
12 \\
8 \\
15 \\
\end{array}$ \\
\hline $\begin{array}{l}49 \\
50 \\
51 \\
52 \\
53 \\
\end{array}$ & $\begin{array}{l}\text { Morocco } \\
\text { Indonesia } \\
\text { Congo } \\
\text { Kenya } \\
\text { Zimbabwe } \\
\end{array}$ & $\begin{array}{r}9 \\
14 \\
15 \\
13 \\
15 \\
\end{array}$ & $\begin{array}{l}95^{*} \\
98^{*} \\
977^{\circ} \\
89^{x} \\
98^{\circ}\end{array}$ & $\begin{array}{l}61^{\circ} \\
97^{\circ} \\
97^{*} \\
84^{x} \\
95^{*} \\
\end{array}$ & $\begin{array}{l}83^{*} \\
85^{\circ} \\
44^{x} \\
84^{*} \\
\end{array}$ & $\begin{array}{l}40^{y} / 5^{y} \\
27^{*} / 3^{*} \\
30^{x} / \% \\
30^{\circ} / 2^{*} \\
\cdots . / \% \\
\end{array}$ & $\begin{array}{l}17 \\
8^{x} \\
\cdots\end{array}$ & $\begin{array}{r}113 \\
117 \\
104 \\
99 \\
100 \\
\end{array}$ & $\begin{array}{r}10 \\
10 \\
10 \\
8 \\
8 \\
\end{array}$ \\
\hline $\begin{array}{l}54 \\
55 \\
56 \\
57 \\
58 \\
\end{array}$ & $\begin{array}{l}\text { Honduras } \\
\text { Algeria } \\
\text { Tunisia } \\
\text { Guatemala } \\
\text { Saudi Arabia } \\
\end{array}$ & $\begin{array}{c}9 \\
9 \\
7 \\
18 \\
6 \\
\end{array}$ & $\begin{array}{l}48^{*} \\
95^{\circ}\end{array}$ & $\begin{array}{l}28^{*} \\
92^{*} \\
94^{x} \\
91^{*}\end{array}$ & $\begin{array}{l}24^{*} \\
71^{\circ} \\
74^{x} \\
52^{*}\end{array}$ & $\begin{array}{l}29^{*} / 2^{*} \\
60^{*} / 4^{\circ} \\
\% \\
\% \\
\end{array}$ & $\begin{array}{c}108 \\
\cdots \\
9\end{array}$ & $\begin{array}{l}104 \\
121 \\
114 \\
108\end{array}$ & $\begin{array}{r}9 ! \\
11 ! \\
9 \\
13:\end{array}$ \\
\hline $\begin{array}{l}59 \\
60 \\
61 \\
62 \\
63 \\
64\end{array}$ & $\begin{array}{l}\text { South Africa } \\
\text { Nicaragua } \\
\text { Turkey } \\
\text { lraq } \\
\text { Botswana } \\
\text { Viet Nam }\end{array}$ & $\begin{array}{r}12 \\
15 \\
7 \\
9 \\
8 \\
18^{*}\end{array}$ & $\begin{array}{l}9 \\
990^{\circ} \\
93^{\circ}\end{array}$ & $\begin{array}{l}\dot{9} i^{*} \\
\dot{90} \\
88^{*}\end{array}$ & $\begin{array}{l}71^{\circ} \\
51^{*} \\
75^{\circ} \\
20^{*}\end{array}$ & $\begin{array}{l}\% \\
\% \\
\% \\
31 \% \\
39^{2} / 13\end{array}$ & $\begin{array}{l}\cdots \\
\cdots \\
19^{*} \\
12^{*}\end{array}$ & $\begin{array}{r}88 \\
90 \\
108 \\
114 \\
96 \\
122\end{array}$ & $\begin{array}{r}11 ! \\
10 ! \\
12 ! \\
11 ! \\
9 ! \\
9\end{array}$ \\
\hline
\end{tabular}

Note: nations are listed in descending order of their 1986 under-five mortality rates (see table 1) 
TABLEAU 2: NUTRITION

\begin{tabular}{|c|c|c|c|c|c|c|c|c|c|c|c|c|c|}
\hline & & \multirow{3}{*}{$\begin{array}{c}\text { Pourcentage } \\
\text { deniants } \\
\text { de poids } \\
\text { insurtisant à } \\
\text { ta anissance } \\
\text { 1980-1988 } \\
\end{array}$} & \multirow{2}{*}{\multicolumn{3}{|c|}{$\begin{array}{l}\text { Pourcentage } \\
\text { de meres allaitant } \\
\text { au sein } \\
1980-1991\end{array}$}} & \multicolumn{4}{|c|}{ Pourcentage d'entants (1980-1991) souffrant de } & \multirow{3}{*}{$\begin{array}{c}\text { Indice moyen } \\
\text { de production } \\
\text { dlinentaire } \\
\text { oar habitant } \\
(1979-81=1000) \\
! 990 \\
\end{array}$} & \multirow{3}{*}{$\begin{array}{c}\text { Apport } \\
\text { joumalier } \\
\text { oe caionies } \\
\text { par haditant } \\
\text { en sh } \\
\text { des besoins } \\
1988 \\
\end{array}$} & \multirow{2}{*}{\multicolumn{2}{|c|}{ 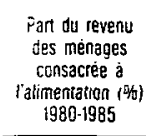 }} \\
\hline & & & & & & \multirow{2}{*}{\multicolumn{2}{|c|}{$\begin{array}{l}\text { taible ooids (0-4 ans) } \\
\text { moderé } \\
\text { Ea grave } \\
\end{array}$}} & \multirow{2}{*}{$\begin{array}{c}\text { émaciation } \\
\text { (12-23 mois) } \\
\text { modérée } \\
\text { et grave } \\
\end{array}$} & \multirow{2}{*}{$\begin{array}{c}\text { retard de } \\
\text { croissance } \\
\text { (24-59 mois) } \\
\text { modere } \\
\text { et grave } \\
\end{array}$} & & & & \\
\hline & & & 3 mois & 6 mois & 12 mois & & & & & & & $\overline{\text { Total }}$ & Céréale \\
\hline & $\begin{array}{l}\text { Pays a TMM5 très éleve } \\
\text { (superieur a 140) } \\
\text { Médiane }\end{array}$ & 17 & 93 & 90 & 82 & 33 & 6 & 14 & 43 & 90 & 92 & 54 & 22 \\
\hline $\begin{array}{l}1 \\
2 \\
3 \\
4 \\
5 \\
\end{array}$ & $\begin{array}{l}\text { Mozambique } \\
\text { Afghanistan } \\
\text { Angola } \\
\text { Mali } \\
\text { Sierra Leone } \\
\end{array}$ & $\begin{array}{l}20^{*} \\
20 \\
17 \\
17^{*} \\
17^{*} \\
\end{array}$ & $\begin{array}{l}99^{*} \\
\cdots \\
9 \dot{9} \\
99^{*}\end{array}$ & $\begin{array}{l}96^{*} \\
74^{x} \\
95 \\
98^{*} \\
\end{array}$ & $\begin{array}{l}61^{x} \\
82 \\
92^{*} \\
\end{array}$ & $\begin{array}{l}\cdots \\
31^{x} \\
23^{x} \\
\end{array}$ & $\begin{array}{l}9^{x} \\
2^{x} \\
\end{array}$ & $\begin{array}{l}\cdots \\
\cdots \\
16 \\
14^{x} \\
\end{array}$ & $\begin{array}{l}\cdots \\
3 \\
34^{x} \\
\ldots\end{array}$ & $\begin{array}{l}85 \\
77 \\
96 \\
88 \\
\end{array}$ & $\begin{array}{l}70 \\
94^{x} \\
73 \\
93 \\
79 \\
\end{array}$ & $\begin{array}{l}\cdots \\
\cdots \\
57 \\
56 \\
\end{array}$ & $\begin{array}{l}\cdots \\
22 \\
22 \\
\end{array}$ \\
\hline $\begin{array}{r}6 \\
7 \\
8 \\
9 \\
10 \\
\end{array}$ & $\begin{array}{l}\text { Malawi } \\
\text { Guinée-Bissau } \\
\text { Guinée } \\
\text { Burkina Faso } \\
\text { Niger } \\
\end{array}$ & $\begin{array}{l}20^{*} \\
13 \\
25^{*} \\
21^{x} \\
15 \\
\end{array}$ & $\begin{array}{r}100 \\
100^{*} \\
98^{*} \\
65 \\
\end{array}$ & $\begin{array}{r}100 \\
90^{\circ} \\
98^{*} \\
30 \\
\end{array}$ & $\begin{array}{l}96^{*} \\
98 \\
85^{*} \\
97^{\circ} \\
15 \\
\end{array}$ & $\begin{array}{l}24^{x} \\
23^{x} \\
\cdots \\
49 \\
\end{array}$ & $\begin{array}{l}\cdots \\
\cdots \\
\cdots \\
\cdots\end{array}$ & $\begin{array}{l}8 \\
\therefore \\
23^{x} \\
\end{array}$ & $\begin{array}{l}61 \\
\cdots \\
38^{x} \\
\end{array}$ & $\begin{array}{r}80 \\
101 \\
87 \\
108 \\
73 \\
\end{array}$ & $\begin{array}{r}87 \\
92 \\
88 \\
87 \\
100 \\
\end{array}$ & $\begin{array}{l}55 \\
\cdots \\
\cdots \\
\ldots\end{array}$ & $\begin{array}{l}28 \\
\ldots \\
\cdots\end{array}$ \\
\hline $\begin{array}{l}11 \\
12 \\
13 \\
14 \\
15\end{array}$ & $\begin{array}{l}\text { Ethiopie } \\
\text { Tchad } \\
\text { Somalie } \\
\text { Mauritanie } \\
\text { Libéria } \\
\end{array}$ & $\begin{array}{l}8 \\
\cdots \\
11 \\
\cdots\end{array}$ & $\begin{array}{l}\ldots \\
92 \\
91 \\
87 \\
\end{array}$ & $\begin{array}{l}97^{*} \\
78^{*} \\
86 \\
75 \\
\end{array}$ & $\begin{array}{l}95^{*} \\
54^{*} \\
67 \\
61 \\
\end{array}$ & $\begin{array}{l}31 \\
\ldots\end{array}$ & $\begin{array}{l}\cdots \\
\cdots \\
\cdots \\
\end{array}$ & $\begin{array}{l}19^{x} \\
\cdots \\
24^{x} \\
\cdots\end{array}$ & $\begin{array}{l}43^{x} \\
\cdots \\
37^{x} \\
\cdots\end{array}$ & $\begin{array}{l}85 \\
94 \\
96 \\
85 \\
72 \\
\end{array}$ & $\begin{array}{r}71 \\
78 \\
75 \\
109 \\
98 \\
\end{array}$ & $\begin{array}{l}50 \\
\cdots \\
\cdots \\
\ldots\end{array}$ & $\begin{array}{l}24 \\
\cdots \\
\cdots \\
\cdots\end{array}$ \\
\hline $\begin{array}{l}16 \\
17 \\
18 \\
19 \\
20 \\
\end{array}$ & $\begin{array}{l}\text { Rwanda } \\
\text { Cambodge } \\
\text { Burundi } \\
\text { Bhoutan } \\
\text { Népal }\end{array}$ & $\dot{9}$ & $\begin{array}{c}97^{*} \\
100^{*} \\
\cdots \\
92^{x} \\
\end{array}$ & $\begin{array}{l}97^{*} \\
93^{*} \\
95^{*} \\
92^{x} \\
\end{array}$ & $\begin{array}{l}74^{*} \\
72^{*} \\
90^{\circ} \\
82^{x} \\
\end{array}$ & $\begin{array}{l}33^{x} \\
38^{x} \\
38^{x} \\
\ldots \\
\end{array}$ & $\begin{array}{l}4^{x} \\
10^{x} \\
\ldots \\
\ldots\end{array}$ & $\begin{array}{c}1^{x} \\
10 \\
4^{x} \\
\cdots\end{array}$ & $\begin{array}{l}34^{x} \\
60^{x} \\
56^{x} \\
\cdots\end{array}$ & $\begin{array}{r}73 \\
160 \\
89 \\
86 \\
109 \\
\end{array}$ & $\begin{array}{l}77 \\
98^{\mathrm{x}} \\
97 \\
94 \\
9\end{array}$ & $\begin{array}{l}30 \\
\cdots \\
57\end{array}$ & $\begin{array}{l}11 \\
\cdots \\
38\end{array}$ \\
\hline $\begin{array}{l}21 \\
22 \\
23 \\
24 \\
25 \\
\end{array}$ & $\begin{array}{l}\text { Yémen } \\
\text { Sénégal } \\
\text { Bangladesh } \\
\text { Madagascar } \\
\text { Soudan }\end{array}$ & $\begin{array}{l}11 \\
47 \\
10^{*} \\
15^{*} \\
\end{array}$ & $\begin{array}{l}74^{x} \\
95 \\
91^{x} \\
95 \\
93 \\
\end{array}$ & $\begin{array}{l}66^{x} \\
91 \\
86^{x} \\
95 \\
90 \\
\end{array}$ & $\begin{array}{l}34^{x} \\
86 \\
82^{x} \\
85 \\
79 \\
\end{array}$ & $\begin{array}{l}53^{x} \\
22^{x} \\
66^{x} \\
33^{x} \\
\cdots \\
\end{array}$ & $\begin{array}{r}6^{x} \\
27^{x} \\
8^{x} \\
\cdots \\
\end{array}$ & $\begin{array}{c}15^{x} \\
8 \\
28 \\
17 \\
13^{x} \\
\end{array}$ & $\begin{array}{l}61^{x} \\
28^{x} \\
66 \\
56^{x} \\
32^{x} \\
\end{array}$ & $\begin{array}{r}79 \\
100 \\
99 \\
90 \\
67 \\
\end{array}$ & $\begin{array}{l}92 \\
84 \\
83 \\
93 \\
85 \\
\end{array}$ & $\begin{array}{l}50 \\
59 \\
59 \\
60 \\
\end{array}$ & $\begin{array}{l}15 \\
36 \\
26 \\
. \\
\end{array}$ \\
\hline $\begin{array}{l}26 \\
27 \\
28 \\
29 \\
30 \\
\end{array}$ & $\begin{array}{l}\text { Tanzanie, Rép.-Unie de } \\
\text { Rép. centratricaine } \\
\text { Namibie } \\
\text { Nigéria } \\
\text { Gabon } \\
\end{array}$ & $\begin{array}{l}14 \\
15^{\circ} \\
20^{*} \\
\cdots\end{array}$ & $\begin{array}{l}100^{*} \\
98^{x} \\
98 \\
\ldots \\
\end{array}$ & $\begin{array}{l}90^{*} \\
88^{x} \\
97 \\
\ldots \\
\end{array}$ & $\begin{array}{l}70^{*} \\
73^{x} \\
92 \\
\end{array}$ & $\begin{array}{l}48^{*} \\
29^{x} \\
36 \\
\ldots\end{array}$ & $\begin{array}{l}6^{*} \\
6^{x} \\
12 \\
\cdots \\
\end{array}$ & $\begin{array}{c}\cdots \\
9^{x} \\
16 \\
\end{array}$ & $\begin{array}{l}\ldots \\
30 x \\
60 \\
\ldots\end{array}$ & $\begin{array}{r}85 \\
95 \\
95 \\
113 \\
80 \\
\end{array}$ & $\begin{array}{r}93 \\
88 \\
83 \\
86 \\
102 \\
\end{array}$ & $\begin{array}{l}64 \\
\cdots \\
52 \\
\cdots\end{array}$ & $\begin{array}{l}32 \\
\cdots \\
18 \\
\cdots\end{array}$ \\
\hline $\begin{array}{l}31 \\
32 \\
33 \\
34 \\
35\end{array}$ & $\begin{array}{l}\text { Ouganda } \\
\text { Bolivie } \\
\text { Pakistan } \\
\text { Rép.dém.pop.lao } \\
\text { Cameroun }\end{array}$ & $\begin{array}{l}12^{*} \\
25^{*} \\
39 \\
13^{x}\end{array}$ & $\begin{array}{l}92 \\
92 \\
87^{*} \\
92^{x}\end{array}$ & $\begin{array}{l}88 \\
84 \\
74^{*} \\
99^{y} \\
90^{x}\end{array}$ & $\begin{array}{l}85 \\
67 \\
70^{*} \\
93^{y} \\
77^{x}\end{array}$ & $\begin{array}{l}23 \\
13^{x} \\
52^{x} \\
37 \\
17^{x}\end{array}$ & $\begin{array}{l}5 \\
3^{x} \\
10^{x} \\
\cdots \\
\cdots\end{array}$ & $\begin{array}{c}4 \\
2 \\
17^{x} \\
20 \\
2^{x}\end{array}$ & $\begin{array}{l}25^{x} \\
51^{x} \\
42^{x} \\
44 \\
43^{x}\end{array}$ & $\begin{array}{r}90 \\
105 \\
105 \\
130 \\
88\end{array}$ & $\begin{array}{r}86 \\
87 \\
95 \\
119 \\
93\end{array}$ & $\begin{array}{l}33 \\
54 \\
24\end{array}$ & $\begin{array}{l}\cdots \\
17 \\
\dot{8}\end{array}$ \\
\hline $\begin{array}{l}36 \\
37 \\
38 \\
\end{array}$ & $\begin{array}{l}\text { Bénin } \\
\text { Togo } \\
\text { Inde }\end{array}$ & $\begin{array}{l}8^{*} \\
20^{*} \\
30\end{array}$ & $\begin{array}{l}90 \\
95\end{array}$ & $\begin{array}{l}90 \\
87 \\
\cdots\end{array}$ & $\begin{array}{l}76 \\
84 \\
\cdots\end{array}$ & $\begin{array}{l}24 \\
61^{x}\end{array}$ & $\begin{array}{l}6 \\
9^{x}\end{array}$ & 10 & $37^{x}$ & $\begin{array}{r}115 \\
96 \\
118\end{array}$ & $\begin{array}{l}93 \\
93 \\
95\end{array}$ & $\begin{array}{l}37 \\
52\end{array}$ & $\begin{array}{l}12 \\
18\end{array}$ \\
\hline & $\begin{array}{l}\text { Pays \& TMM5 élevé } \\
\text { (71-140) } \\
\text { Médiane }\end{array}$ & 14 & 90 & 82 & 76 & 16 & 2 & 4 & 34 & 94 & 105 & 40 & 12 \\
\hline $\begin{array}{l}39 \\
40 \\
41 \\
42 \\
43\end{array}$ & $\begin{array}{l}\text { Ghana } \\
\text { Côte d'Ivoire } \\
\text { Haiti } \\
\text { Zaïre } \\
\text { Lesotho }\end{array}$ & $\begin{array}{l}17^{*} \\
14^{x} \\
17^{x} \\
13 \\
11 \\
\end{array}$ & $\begin{array}{c}90 \\
87 \\
92^{*} \\
100^{*} \\
93^{x}\end{array}$ & $\begin{array}{c}92 \\
84 \\
80^{*} \\
100^{*} \\
89^{x}\end{array}$ & $\begin{array}{l}87 \\
78 \\
86^{*} \\
76^{x}\end{array}$ & $\begin{array}{l}27 \\
12 \\
37 x \\
16\end{array}$ & $\begin{array}{l}6 \\
2 \\
3^{x} \\
2 \\
2\end{array}$ & $\begin{array}{l}15 \\
17 \\
17 x \\
7\end{array}$ & $\begin{array}{l}39 \\
20 \\
51^{x} \\
23 \\
\end{array}$ & $\begin{array}{r}102 \\
92 \\
89 \\
95 \\
76 \\
\end{array}$ & $\begin{array}{r}96 \\
102 \\
85 \\
92 \\
101\end{array}$ & $\begin{array}{l}66 \\
40 \\
55 \\
-\end{array}$ & $\begin{array}{l}14 \\
16 \\
\end{array}$ \\
\hline $\begin{array}{l}44 \\
45 \\
46 \\
47 \\
48\end{array}$ & $\begin{array}{l}\text { Zambie } \\
\text { Pérou } \\
\text { Jamahiriya arabe libyenne } \\
\text { Maroc } \\
\text { Congo } \\
\end{array}$ & $\begin{array}{l}\dot{9} \\
\dot{1} \\
1 \sigma^{*}\end{array}$ & $\begin{array}{r}85 \\
87 \\
100^{*} \\
\end{array}$ & $\begin{array}{l}76 \\
77 \\
98^{*}\end{array}$ & $\begin{array}{l}93^{*} \\
58 \\
59 \\
90^{*}\end{array}$ & $\begin{array}{l}25^{x} \\
13^{x} \\
16^{x} \\
24 \\
\end{array}$ & $\begin{array}{l}5^{x} \\
2^{x} \\
4^{x} \\
\end{array}$ & $\begin{array}{c}10^{x} \\
3 \\
-9 \\
13 \\
\end{array}$ & $\begin{array}{l}59^{x} \\
43 \\
34^{x} \\
33 \\
\end{array}$ & $\begin{array}{r}86 \\
90 \\
102 \\
124 \\
92 \\
\end{array}$ & $\begin{array}{r}88 \\
97 \\
143 \\
117 \\
113 \\
\end{array}$ & $\begin{array}{l}37 \\
35 \\
40 \\
42 \\
\end{array}$ & $\begin{array}{l}\varepsilon \\
\varepsilon \\
i \varepsilon \\
1 \xi\end{array}$ \\
\hline $\begin{array}{l}49 \\
50 \\
51 \\
52 \\
53\end{array}$ & $\begin{array}{l}\text { Kenya } \\
\text { Algérie } \\
\text { Indonésie } \\
\text { Guatemala } \\
\text { Arabie saoudite }\end{array}$ & $\begin{array}{c}15 \\
9^{*} \\
14 \\
14^{*} \\
6\end{array}$ & $\begin{array}{l}94 \\
95 \\
95 \\
91^{*}\end{array}$ & $\begin{array}{l}92 \\
87 \\
79 \\
52^{*}\end{array}$ & $\begin{array}{l}82 \\
79 \\
80 \\
\cdots\end{array}$ & $\begin{array}{l}10^{x} \\
51^{x} \\
34^{x} \\
\cdots\end{array}$ & $\begin{array}{l}j^{x} \\
8^{x} \\
.\end{array}$ & $\begin{array}{c}10^{x} \\
4^{x} \\
3 \\
3 \\
\cdots\end{array}$ & $\begin{array}{l}41^{x} \\
13^{x} \\
68^{x} \\
\cdots \\
\end{array}$ & $\begin{array}{r}108 \\
94 \\
132 \\
95 \\
252 \\
\end{array}$ & $\begin{array}{r}85 \\
114 \\
124 \\
107 \\
117 \\
\end{array}$ & $\begin{array}{l}39 \\
61 \\
36\end{array}$ & $\begin{array}{l}16 \\
18 \\
11\end{array}$ \\
\hline $\begin{array}{l}54 \\
55 \\
56 \\
57 \\
58\end{array}$ & $\begin{array}{l}\text { Afrique du Sud } \\
\text { Myanmar } \\
\text { El Salvador } \\
\text { Zimbabwe } \\
\text { Iraq }\end{array}$ & $\begin{array}{l}12 \\
16^{*} \\
15^{*} \\
9^{*}\end{array}$ & $\begin{array}{l}90 \\
85 \\
95 \\
76\end{array}$ & $\begin{array}{l}90 \\
77 \\
92 \\
45\end{array}$ & $\begin{array}{l}90 \\
55 \\
88 \\
19\end{array}$ & $\begin{array}{l}38^{x} \\
15 \\
12^{x}\end{array}$ & $\dot{2}^{x}$ & $\begin{array}{r}17 \\
3 \\
2\end{array}$ & $\begin{array}{l}75^{x} \\
36 \\
31^{x} \\
\cdots \\
\end{array}$ & $\begin{array}{l}85 \\
96 \\
94 \\
92 \\
92 \\
\end{array}$ & $\begin{array}{r}124 \\
119 \\
105 \\
93 \\
123 \\
\end{array}$ & $\begin{array}{l}26 \\
33 \\
40 \\
\ldots\end{array}$ & i: \\
\hline $\begin{array}{l}59 \\
60 \\
61 \\
62 \\
63\end{array}$ & $\begin{array}{l}\text { Egypte } \\
\text { Botswana } \\
\text { Turquie } \\
\text { Mongolie } \\
\text { Honduras }\end{array}$ & $\begin{array}{c}5 \\
8^{*} \\
7^{*} \\
10 \\
20^{*}\end{array}$ & $\begin{array}{l}90 \\
97 \\
98^{*} \\
70^{*} \\
73^{*}\end{array}$ & $\begin{array}{l}83 \\
90 \\
72^{*} \\
55^{*}\end{array}$ & $\begin{array}{l}68 \\
73 \\
63^{*} \\
\ldots \\
\ldots\end{array}$ & $\begin{array}{l}13^{x} \\
15 \\
\cdots \\
21\end{array}$ & $\begin{array}{l}3^{x} \\
4 \\
4\end{array}$ & $\begin{array}{l}2 \\
\therefore \\
\therefore \\
2^{x}\end{array}$ & $\begin{array}{l}32^{x} \\
51^{x} \\
\cdots \\
34^{x}\end{array}$ & $\begin{array}{r}123 \\
75 \\
98 \\
88 \\
89\end{array}$ & $\begin{array}{r}128 \\
98 \\
122 \\
101 \\
96\end{array}$ & $\begin{array}{l}50 \\
35 \\
40 \\
39\end{array}$ & $\begin{array}{c}11 \\
1: \\
i \\
.\end{array}$ \\
\hline
\end{tabular}




\begin{tabular}{|c|c|c|c|c|c|c|c|c|c|c|}
\hline & & \multirow{3}{*}{$\begin{array}{c}\text { of of } \\
\text { population with } \\
\text { access to } \\
\text { drinking water } \\
\text { 1983-86 } \\
\text { Total/urban/urai }\end{array}$} & \multirow{3}{*}{$\begin{array}{c}\text { \%o of } \\
\text { population with } \\
\text { access to } \\
\text { health services } \\
1980-86 \\
\text { Total/urban/ural }\end{array}$} & \multicolumn{5}{|c|}{ Percentage fully immunized 1981/1985-86 } & \multirow{3}{*}{$\begin{array}{l}\text { ORS } \\
\text { pers 100 } \\
\text { episodes of } \\
\text { Diarrhoea } \\
\text { (litres) } \\
1985\end{array}$} & \multirow{3}{*}{$\begin{array}{c}\text { \%o of } \\
\text { births } \\
\text { attended by } \\
\text { traned heathn } \\
\text { Dersonnel } \\
1984\end{array}$} \\
\hline & & & & \multicolumn{4}{|c|}{ One-year-oid children } & \multirow{2}{*}{$\begin{array}{l}\text { Pregnant } \\
\text { women } \\
\text { Telanus }\end{array}$} & & \\
\hline & & & & iB & DPT & Polio & Measles & & & \\
\hline & $\begin{array}{l}\text { Vory high U5MA } \\
\text { countries (over 170) } \\
\text { Modian }\end{array}$ & $29 / 61 / 21$ & $40 / 80 / 30$ & $27 / 46$ & $14 / 20$ & $8 / 21$ & $19 / 39$ & $5 / 12$ & 20 & 22 \\
\hline $\begin{array}{l}1 \\
2 \\
3 \\
4 \\
5 \\
\end{array}$ & $\begin{array}{l}\text { Afghanistan } \\
\text { Mali } \\
\text { Sierra Leone } \\
\text { Malawi } \\
\text { Ethiopia. } \\
\end{array}$ & $\begin{array}{c}16^{*} / 56^{*} / 10^{*} \\
12^{*} / 23^{*} / 9^{*} \\
22 / 61 / 6 \\
51 / 66 / 49 \\
6^{*} / \ldots / . \\
\end{array}$ & $\begin{array}{c}29 * / 80^{*} / 17^{*} \\
15 / \ldots \% \\
80 \% \ldots \% \\
46^{*} / \ldots \% \\
\end{array}$ & $\begin{array}{c}8 / 16 \\
19 / 15^{*} \\
35 / 80^{x} \\
86 / 79 \\
10 / 12^{y} \\
\end{array}$ & $\begin{array}{c}3 / 9 \\
i / 3^{*} \\
15 / 21^{x} \\
66 / 54 \\
6 / 6^{\prime} \\
\end{array}$ & $\begin{array}{c}3 / 9 \\
1 / 3^{*} \\
13 / 21^{x} \\
68 / 55 \\
7 / 6^{y} \\
\end{array}$ & $\begin{array}{c}6 / 12 \\
1.15^{\circ} \\
28 / 66^{x} \\
65 / 42 \\
7 / 9^{y} \\
\end{array}$ & $\begin{array}{c}3 / 10 \\
1 / 3^{*} \\
10 / 17^{x} \\
. / 47^{*} \\
.16^{*}\end{array}$ & $\begin{array}{r}37 \\
8 \\
57 \\
9 \\
38\end{array}$ & $\begin{array}{l}25 \\
59 \\
58\end{array}$ \\
\hline $\begin{array}{r}6 \\
7 \\
8 \\
9 \\
10 \\
\end{array}$ & $\begin{array}{l}\text { Guinea } \\
\text { Somalia } \\
\text { Mozambique } \\
\text { Burkina Faso } \\
\text { Angola } \\
\end{array}$ & $\begin{array}{c}17 / 69 / 2 \\
36 / 65 / 21 \\
13 y / 50 y / 7 y \\
30 / 27 / 31 \\
28 / 90 / 12 \\
\end{array}$ & $\begin{array}{c}27^{*} / 50^{\circ} / 15^{*} \\
30^{\circ} \% / 51^{*} / 48^{*} \\
49 * \% / \\
30 \%\end{array}$ & $\begin{array}{c}4 * / 46^{*} \\
3 / 29 \\
46 / 45^{*} \\
16 / 67 \\
.159^{*} \\
\end{array}$ & $\begin{array}{c}1 / 10^{*} \\
2 / 18 \\
56 / 32^{*} \\
2 / 36 \\
. / 20^{*} \\
\end{array}$ & $\begin{array}{r}. / 8^{*} \\
2 / 18 \\
32 / 32^{*} \\
2 / 36 \\
. / 58^{*} \\
\end{array}$ & $\begin{array}{c}15^{*} / 41^{y} \\
3 / 26 \\
32 / 39^{*} \\
23 / 68 \\
. .144^{*} \\
\end{array}$ & $\begin{array}{c}5 * / 17^{*} \\
5 / 7 \\
.1 / 59^{*} \\
11 / 1^{\circ} \\
. .154^{*}\end{array}$ & $\begin{array}{r}2 \\
27 \\
10 \\
8 \\
17\end{array}$ & $\begin{array}{l}2 \\
28 \\
15\end{array}$ \\
\hline $\begin{array}{l}11 \\
12 \\
13 \\
14 \\
15 \\
\end{array}$ & $\begin{array}{l}\text { Niger } \\
\text { Chad } \\
\text { Guinea-Bissau } \\
\text { Central African Rep. } \\
\text { Senegal }\end{array}$ & $\begin{array}{c}34 / 41 / 33 \\
26 / / \\
33 / 21 / 37 \\
16^{* /} / 1 . \\
42 / 69 / 27\end{array}$ & 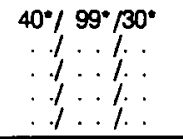 & $\begin{array}{l}28 / 27 y \\
. / 15 \\
.147^{*} \\
26 / 59 y \\
.132\end{array}$ & $\begin{array}{c}6 / 4^{y} \\
. / 3 \\
1 / 111^{*} \\
12 / 24^{y} \\
. / 54 \\
\end{array}$ & $\begin{array}{l}6 / 23^{y} \\
. / 3 \\
. / 11^{*} \\
12 / 24^{y} \\
. .154 \\
\end{array}$ & $\begin{array}{l}19 / 49 y \\
. / 7 \\
. / 34^{*} \\
16 / 30^{y} \\
. / 40 \\
\end{array}$ & $\begin{array}{l}3 / 16^{*} \\
. / 3 \\
1 / 16^{*} \\
13 / 20^{\circ} \\
. / 8\end{array}$ & $\begin{array}{l}2 \\
28 \\
19 \\
23 \\
10\end{array}$ & $\begin{array}{l}47 \\
\cdots \\
\cdots \\
\cdots\end{array}$ \\
\hline $\begin{array}{l}16 \\
17 \\
18 \\
19 \\
20 \\
\end{array}$ & $\begin{array}{l}\text { Mauritania } \\
\text { Liberia } \\
\text { Rwanda } \\
\text { Kampuchea } \\
\text { Yemen } \\
\end{array}$ & $\begin{array}{l}20 \% / 80 / \% \\
59 / 55 / 60 \\
31 \% 99 * / 21 \\
\end{array}$ & $\begin{array}{l}30^{*} / / 10^{*} / 120^{*} \\
28^{*} / 140^{\circ} / 125^{*} \\
27^{*} / 60^{\circ} \\
55^{\circ} / 150^{*} \\
30^{\circ} / 75^{\circ} / 24^{*}\end{array}$ & $\begin{array}{l}57 / 74^{4} \\
87 / 50^{*} \\
51 / 86^{\circ} \\
1.154^{*} \\
15 / 28 \\
\end{array}$ & $\begin{array}{l}18 / 21^{y} \\
39 / 25^{*} \\
17 / 67^{*} \\
. / 37^{*} \\
25 / 16 \\
\end{array}$ & $\begin{array}{l}18 / 21^{y} \\
26 / 25^{*} \\
15 / 72^{*} \\
25 / 35^{*} \\
25 / 16 \\
\end{array}$ & $\begin{array}{l}45 / 59^{y} \\
4 . / 50^{\circ} \\
42 / 55^{\circ} \\
4 / 54^{\circ} \\
40 / 19 \\
\end{array}$ & $\begin{array}{l}1 / / 16^{*} \\
5 / 26^{*} \\
1 / 3^{*} \\
/ 3\end{array}$ & $\begin{array}{r}2 \\
5 \\
24 \\
91 \\
20\end{array}$ & $\begin{array}{l}23 \\
89 \\
\cdots \\
12\end{array}$ \\
\hline $\begin{array}{l}21 \\
22 \\
23 \\
24 \\
25 \\
\end{array}$ & $\begin{array}{l}\text { Yemen, Dem. } \\
\text { 8hutan } \\
\text { Nepal } \\
\text { Burundi } \\
\text { Bangladesh } \\
\end{array}$ & $\begin{array}{c}53^{\circ} / 79^{\circ} / 39^{\circ} \\
15 / 40 / 14 \\
15 / 71 / 11 \\
39 / 94 / 22 \\
41 / 29 / 43 \\
\end{array}$ & $\begin{array}{c}30 \% \ldots / \\
19 / \ldots / \% \\
45 \% / 90^{\circ} / 30^{\circ} \\
45 \% \ldots / \ldots\end{array}$ & $\begin{array}{c}9 / 12 \\
36 / 32 \\
32 / 67 \\
65 / 80 \\
1 / 5 \\
\end{array}$ & $\begin{array}{c}5 / 6 \\
8 / 16 \\
16 / 38 \\
38 / 60 \\
1 / 5 \\
\end{array}$ & $\begin{array}{l}5 / 5 \\
7 / 16 \\
1 / 34 \\
6 / 61 \\
1 / 4 \\
\end{array}$ & $\begin{array}{l}6 / 6 \\
9 / 15 \\
2 / 66 \\
30 / 57 \\
(.) / 3 \\
\end{array}$ & $\begin{array}{c}3 / 5 \\
. / 4 \\
4 / 13 \\
25 / 17 \\
1 / 5 \\
\end{array}$ & $\begin{array}{r}105 \\
21 \\
14 \\
26 \\
18 \\
\end{array}$ & $\begin{array}{r}10 \\
3 \\
10 \\
12\end{array}$ \\
\hline $\begin{array}{l}26 \\
27 \\
28 \\
29\end{array}$ & $\begin{array}{l}\text { Benin } \\
\text { Sudan } \\
\text { Tanzania, U. Rep. of } \\
\text { Bolivia }\end{array}$ & $\begin{array}{lll}18 / 26 & / 15 \\
25 / 60 & / 10 \\
50 / 88 & / 39 \\
43 / 77 / 12\end{array}$ & $\begin{array}{l}40^{*} / 190 \% / 140 \\
55 / 90 \% \\
76^{\prime} / 99^{y} / 72^{y} \\
23^{*} / \ldots / .\end{array}$ & $\begin{array}{c}. / 44^{*} \\
3 / 23 \\
78 / 82^{*} \\
30 / 15^{*}\end{array}$ & $\begin{array}{c}/ 19 * \\
1 / 14 \\
58 / 60^{*} \\
13 / 38^{*}\end{array}$ & $\begin{array}{c}1 / 19^{\circ} \\
1 / 14 \\
49 / 62^{\circ} \\
15 / 31^{\circ}\end{array}$ & $\begin{array}{r}. / 22^{*} \\
1 / 11 \\
76 / 67^{\circ} \\
17^{\times} / 65^{\circ} \\
\end{array}$ & $\begin{array}{l}. / 82^{x} \\
1 / 6 \\
36 / 58 \\
. / 1 \\
\end{array}$ & $\begin{array}{l}12 \\
87 \\
36 \\
97 \\
\end{array}$ & $\begin{array}{l}34 \\
20 \\
74 \\
\cdots\end{array}$ \\
\hline \multirow[t]{2}{*}{$\begin{array}{l}30 \\
31 \\
32 \\
33 \\
\end{array}$} & $\begin{array}{l}\text { Nigeria } \\
\text { Haiti } \\
\text { Gabon } \\
\text { Uganda }\end{array}$ & $\begin{array}{l}33 / 58 / 25 \\
32^{\circ} / 50^{\circ} / 25^{\circ} \\
16^{\circ} / 90^{\circ} / 7^{*} \\
\end{array}$ & $\begin{array}{l}40^{*} / 75^{\circ} / 30^{\circ} \\
55^{*} \% / \% \\
61 \% 90^{\circ} / 57^{*}\end{array}$ & $\begin{array}{l}23 / 30 \\
60 / 57 \\
18 / 79 t^{*}\end{array}$ & $\begin{array}{c}24^{*} / 14 \\
14 / 19 \\
\cdot / 48^{y} \\
9 / 21^{*}\end{array}$ & $\begin{array}{c}24 \% / 14 \\
3 / 19 \\
. / 48^{y} \\
8 / 21^{*} \\
\end{array}$ & $\begin{array}{l}55 / 16 \\
. / 21 \\
22 / 55 \\
22 / 33^{*} \\
\end{array}$ & $\begin{array}{l}11 / 11 \\
\cdot 156^{*} \\
20 / 15^{\circ}\end{array}$ & $\begin{array}{r}2 \\
7 \\
27 \\
21 \\
\end{array}$ & 20 \\
\hline & $\begin{array}{l}\text { High U5MR countries } \\
\text { (9s-170) } \\
\text { Median }\end{array}$ & $51 / 73 / 33$ & $74 / 99 / 62$ & $55 / 73$ & $35 / 54$ & $37 / 58$ & $26 / 51$ & $8 / 22$ & 22 & 60 \\
\hline $\begin{array}{l}34 \\
35 \\
36 \\
37 \\
38\end{array}$ & $\begin{array}{l}\text { Pakistan } \\
\text { Zaire } \\
\text { Lao People's Dem. Rep. } \\
\text { Oman } \\
\text { Iran (Islamic Rep. of) }\end{array}$ & $\begin{array}{l}47^{*} / 83^{*} / 38^{*} \\
17^{*} / 35^{\circ} / 5^{*} \\
21 / 28 / 120 \\
144^{y} / 70^{y} / 10^{4} \\
76^{*} / 95^{\circ} / 55^{\circ} \\
\end{array}$ & $\begin{array}{l}55^{\circ} / 99^{\circ} / 35^{\circ} \\
25^{\circ} / / / 1 / \\
91^{\circ} / 100^{\circ} / 90^{\circ} \\
71^{\circ} / 95^{\circ} / 45^{\circ}\end{array}$ & $\begin{array}{c}11 / 68 \\
34 / 45^{*} \\
4 / 11^{\circ} \\
49 / 90^{\circ} \\
6 / 75 \\
\end{array}$ & $\begin{array}{r}3 / 55 \\
18 / 30^{*} \\
7 * / 8^{*} \\
9 / 84^{*} \\
29 / 69 \\
\end{array}$ & $\begin{array}{r}3 / 55 \\
18 / 30^{\circ} \\
7 \% / 8^{\circ} \\
9 / 84^{\circ} \\
47 / 72 \\
\end{array}$ & $\begin{array}{r}2 / 40 \\
17 / 30^{*} \\
74^{*} \\
6 / 76^{*} \\
48 / 73 \\
\end{array}$ & $\begin{array}{r}1 / 28 \\
2 / 35^{*} \\
27 / 8^{*} \\
27 / 28 \\
2 / 28 \\
\end{array}$ & $\begin{array}{r}28 \\
4 \\
34 \\
82 \\
11 \\
\end{array}$ & $\begin{array}{l}24 \\
\cdots \\
60 \\
.\end{array}$ \\
\hline $\begin{array}{l}39 \\
40 \\
41 \\
42 \\
43 \\
\end{array}$ & $\begin{array}{l}\text { Cameroon } \\
\text { Togo } \\
\text { India } \\
\text { Cote d'lvoire } \\
\text { Ghana } \\
\end{array}$ & $\begin{array}{ll}26 x / & / 1 \\
35 / 68 & / 26 \\
54 / 80 & / 47 \\
18 / 30 & / 10 \\
50 / 72 / 47 \\
\end{array}$ & $\begin{array}{l}61^{*} / 1 / \\
32^{*} / 61^{*} / 11 \% \\
60^{*} / 92^{\circ} / 45^{*}\end{array}$ & $\begin{array}{c}8 / 83^{*} \\
44 / 66^{y} \\
12 / 29 \\
70 / 16^{y} \\
67 / 37 y \\
\end{array}$ & $\begin{array}{r}5 / 45^{*} \\
9 / 41^{y} \\
31 / 53 \\
42 / 11^{y} \\
22 / 14^{y} \\
\end{array}$ & $\begin{array}{r}5 / 42^{*} \\
9 / 40^{y} \\
7 / 45 \\
34 / 11^{y} \\
25 / 13^{y}\end{array}$ & $\begin{array}{l}16 / 44^{*} \\
47 / 48^{y} \\
28 / 1 \\
28 / 31 y \\
23 / 45^{y}\end{array}$ & $\begin{array}{l}57 / 17^{*} \\
57 / 64^{*} \\
24 / 40 \\
25 / 32^{y} \\
11 / 8^{*}\end{array}$ & $\begin{array}{r}1 \\
21 \\
5 \\
17 \\
26 \\
\end{array}$ & $\begin{array}{l}\cdots \\
33 \\
73 \\
\end{array}$ \\
\hline $\begin{array}{l}44 \\
45 \\
46 \\
47 \\
48\end{array}$ & $\begin{array}{l}\text { Lesotho } \\
\text { Zambia } \\
\text { Egypt } \\
\text { Peru } \\
\text { Libyan Arab Jamahiriya }\end{array}$ & $\begin{array}{l}14 / 37 / 11 \\
47 / 65 / 33 \\
75 / 88 / 64 \\
55 / 73 / 18 \\
96 / 100 / 90\end{array}$ & $\begin{array}{l}75^{*} / 1 / 2 \\
\cdots / 17^{*} \\
\cdots \\
\end{array}$ & $\begin{array}{c}81 / 91 y \\
72^{*} / 82^{*} \\
71 / 84 \\
63 / 53^{*} \\
55 / 77 \\
\end{array}$ & $\begin{array}{c}56 / 82^{y} \\
44^{*} / 46^{*} \\
82 / 87 \\
18 / 50^{*} \\
55 / 62 \\
\end{array}$ & $\begin{array}{c}54 / 80^{y} \\
77^{*} / 46^{*} \\
84 / 86 \\
18 / 50^{*} \\
55 / 62 \\
\end{array}$ & $\begin{array}{c}49 / 73^{y} \\
21^{*} / 55^{*} \\
65 / 85 \\
24^{*} / 41^{*} \\
57 / 50 \\
\end{array}$ & $\begin{array}{l}0 * / 0^{*} \\
. / 38^{*} \\
10 / 8 \\
4 / 6^{*} \\
6 / 12 \\
\end{array}$ & $\begin{array}{l}41 \\
42 \\
21 \\
15 \\
\cdots \\
\end{array}$ & $\begin{array}{l}28 \\
24 \\
44 \\
76 \\
\end{array}$ \\
\hline $\begin{array}{l}49 \\
50 \\
51 \\
52 \\
53\end{array}$ & $\begin{array}{l}\text { Morocco } \\
\text { Indonesia } \\
\text { Congo } \\
\text { Kenya } \\
\text { Zimbabwe }\end{array}$ & $\begin{array}{c}30^{*} / 63^{*} / 2^{*} \\
36^{*} / 53^{*} / 30^{*} \\
21 / 42 / 7 \\
28 / 61 / 21 \\
52^{2} / 6 \ldots \\
\end{array}$ & $\begin{array}{l}73^{*} / 100^{*} / 50^{*} \\
75^{*} / \% / \% \\
71^{\circ} / 100^{*} / 62^{*}\end{array}$ & $\begin{array}{l}171 \\
55 / 67 \\
92 / 91^{\circ} \\
1 / 80 \\
64 / 76^{*} \\
\end{array}$ & $\begin{array}{l}43 / 53 \\
(.) / 48 \\
42 / 65 \\
.772 \\
39 / 63^{*}\end{array}$ & $\begin{array}{l}45 / 53 \\
.(.) / 46 \\
42 / 71^{y} \\
.72 \\
38 / 63^{*}\end{array}$ & $\begin{array}{l}. / 48 \\
(.) / 47 \\
49 / 86^{\circ} \\
. / 65 \\
56 / 53^{\circ}\end{array}$ & $\begin{array}{l}1 / 126 \\
10 / 26 \\
. / 11^{\circ} \\
. / 40 \\
. / 40^{\circ} \\
\end{array}$ & $\begin{array}{r}18 \\
22 \\
23 \\
10 \\
4 \\
\end{array}$ & $\begin{array}{l}43^{\circ} \\
\cdots \\
69\end{array}$ \\
\hline $\begin{array}{l}54 \\
55 \\
56 \\
57 \\
58 \\
\end{array}$ & $\begin{array}{l}\text { Honduras } \\
\text { Algeria } \\
\text { Tunisia } \\
\text { Guatemala } \\
\text { Saudi Arabia } \\
\end{array}$ & $\begin{array}{c}69 / 91 / 55 \\
89^{*} / 100^{*} / 80^{*} \\
75^{*} / 100^{*} / 50^{*} \\
51 / 90 / 26 \\
91 / 100 / 68 \\
\end{array}$ & $\begin{array}{c}73 / 85 / 65 \\
89 / 100 / 80 \\
90^{*} / 100^{*} / 80^{*} \\
34^{*} / 47^{*} / 25^{*} \\
97^{\circ} / 100^{*} / 88^{*} \\
\end{array}$ & $\begin{array}{l}46 / 67^{*} \\
59 / 88^{y} \\
65 / 80 \\
29 / 30 \\
49 / 88^{y} \\
\end{array}$ & $\begin{array}{c}38 / 62^{*} \\
33 / 68^{4} \\
36 / 70 \\
42^{x} / 31^{*} \\
53 / 84^{4}\end{array}$ & $\begin{array}{c}37 / 62^{*} \\
30 / 68^{y} \\
37 / 70 \\
42^{x} / 32^{*} \\
52 / 84^{y} \\
\end{array}$ & $\begin{array}{c}38^{x} / 55^{*} \\
17 / 67^{y} \\
65 / 65 \\
8 / 42 \\
12 / 79^{y} \\
\end{array}$ & $\begin{array}{l}11 / 18 \\
1 / 11 \\
2 / 11 \\
1 / 2 \\
.1\end{array}$ & $\begin{array}{r}120 \\
22 \\
106 \\
11 \\
48 \\
\end{array}$ & $\begin{array}{l}50 \\
60 \\
78 \\
\end{array}$ \\
\hline $\begin{array}{l}59 \\
60 \\
61 \\
62 \\
63 \\
64\end{array}$ & $\begin{array}{l}\text { South Africa } \\
\text { Nicaragua } \\
\text { Turkey } \\
\text { lraa } \\
\text { Botswana } \\
\text { Viet Nam }\end{array}$ & $\begin{array}{c}56 / 91 / 10 \\
63^{y} / 63^{y} / 63^{y} \\
89^{*} / 100^{*} / 46^{*} \\
65 / 98 / 47 \\
41^{\circ} / 60^{\circ} / 32^{*}\end{array}$ & $\begin{array}{l}83^{*} / 100^{*} / 60^{*} \\
93^{*} / 97^{*} / 78^{*} \\
89^{*} / 100^{*} / 85^{*} \\
80^{*} / 100^{*} / 75^{*}\end{array}$ & $\begin{array}{l}65 / 95^{\circ} \\
42 / 24^{*} \\
76 / 78^{\circ} \\
80 / 67 \\
. / 57\end{array}$ & $\begin{array}{l}23 / 45^{*} \\
64 / 45 \\
13 / 91^{\circ} \\
64 / 64 \\
. / 43\end{array}$ & $\begin{array}{l}52 / 80^{*} \\
69 / 45 \\
16 / 91 * \\
71 / 60 \\
. . / 44\end{array}$ & $\begin{array}{l}1 / 1 \% \\
20 / 51 \\
52 / 36 \\
33 / 75^{*} \\
68 / 62 \\
\cdots .137\end{array}$ & $\begin{array}{l}. / 1 \\
. / 25^{*} \\
4 / 43^{*} \\
42 / 16 \\
.1 \%\end{array}$ & $\begin{array}{r}92 \\
3 \\
39 \\
38 \\
10\end{array}$ & $\begin{array}{l}\cdots \\
78^{y} \\
60 \\
52^{y} \\
99\end{array}$ \\
\hline
\end{tabular}

Note: nations are listed in descending order of their 1986 under-five mortality rates (see table 1) 


\begin{tabular}{|c|c|c|c|c|c|c|c|c|c|c|c|c|}
\hline & & \multirow{2}{*}{\multicolumn{3}{|c|}{$\begin{array}{l}\text { Pourcentage } \\
\text { de la population } \\
\text { oyant access aे } \\
\text { de l'ezu saine } \\
1988-1990\end{array}$}} & \multirow{2}{*}{\multicolumn{3}{|c|}{$\begin{array}{l}\text { Pourcentage } \\
\text { de la population } \\
\text { ayant acces à des } \\
\text { semces de sanie } \\
1985-1990\end{array}$}} & \multicolumn{5}{|c|}{ Pourcentage ofindividus compietement vaccinès 1981/989-1990 } \\
\hline & & & & & & & & \multicolumn{4}{|c|}{ Entants d'un an } & \multirow{2}{*}{$\begin{array}{c}\text { Femmes } \\
\text { enceintes } \\
\text { Tétanos }\end{array}$} \\
\hline & & Tolal & Uibain & Fiural & Total & Urtbain & fiurai & Tubercuilose & arc & Polio & Pougeale & \\
\hline & $\begin{array}{l}\text { Paye TMM5 tres dleve } \\
\text { (supérieur a 140) } \\
\text { Modiane }\end{array}$ & 42 & 66 & 34 & 46 & 88 & 38 & 24/85 & $14 / 55$ & $8 / 54$ & $23 / 55$ & $5 / 44$ \\
\hline $\begin{array}{l}1 \\
2 \\
3 \\
4 \\
5\end{array}$ & $\begin{array}{l}\text { Mozambique } \\
\text { Afghanistan } \\
\text { Angola } \\
\text { Mali } \\
\text { Sierra Leone }\end{array}$ & $\begin{array}{l}24 \\
21 \\
35 \\
41 \\
42 \\
\end{array}$ & $\begin{array}{l}44 \\
39 \\
75 \\
53 \\
83\end{array}$ & $\begin{array}{l}17 \\
17 \\
19 \\
38 \\
22 \\
\end{array}$ & $\begin{array}{l}39 \\
29 \\
30^{x} \\
15 \\
. \\
\end{array}$ & $\begin{array}{r}100 \\
80 \\
. \\
. \\
.\end{array}$ & $\begin{array}{l}30 \\
17 \\
. \\
. \\
. \\
\end{array}$ & $\begin{array}{r}46 / 59 \\
8 / 30 \\
. / 47 \\
19 / 82 \\
35 / 98 \\
\end{array}$ & $\begin{array}{r}56 / 46 \\
3 / 25 \\
. \quad / 23 \\
.142 \\
15 / 83\end{array}$ & $\begin{array}{r}32 / 46 \\
3 / 25 \\
. \quad / 23 \\
. \quad / 42 \\
13 / 83\end{array}$ & $\begin{array}{r}32 / 58 \\
6 / 20 \\
. \quad .38 \\
. \quad .43 \\
28 / 75\end{array}$ & $\begin{array}{r}. / 25 \\
3 / 3 \\
. / 26 \\
1 / 31 \\
10 / 77\end{array}$ \\
\hline $\begin{array}{r}6 \\
7 \\
8 \\
9 \\
10\end{array}$ & $\begin{array}{l}\text { Malawi } \\
\text { Guinée-Bissau } \\
\text { Guinée } \\
\text { Burkina Faso } \\
\text { Niger }\end{array}$ & $\begin{array}{l}56^{x} \\
25 \\
32 \\
69 \\
61\end{array}$ & $\begin{array}{r}97^{x} \\
18 \\
55 \\
44 \\
100\end{array}$ & $\begin{array}{l}50 x \\
27 \\
24 \\
72 \\
52\end{array}$ & $\begin{array}{l}80 \\
47 \\
49 x \\
41\end{array}$ & $\begin{array}{c}100 \\
51^{x} \\
99\end{array}$ & $\begin{array}{l}40 \\
48^{x} \\
30\end{array}$ & $\begin{array}{r}86 / 97 \\
190 \\
4 / 53 \\
16 / 84 \\
28 / 50\end{array}$ & $\begin{array}{r}66 / 81 \\
\cdot / 38 \\
\cdot / 17 \\
2 / 37 \\
6 / 13\end{array}$ & $\begin{array}{r}68 / 79 \\
. \quad / 38 \\
. .117 \\
2 / 37 \\
6 / 13\end{array}$ & $\begin{array}{r}65 / 80 \\
. / 42 \\
15 / 18 \\
23 / 42 \\
19 / 21 \\
\end{array}$ & $\begin{array}{r}. / 82 \\
. / 44 \\
5 / 10 \\
11 / 76 \\
3 / 44\end{array}$ \\
\hline $\begin{array}{l}11 \\
12 \\
13 \\
14 \\
15 \\
\end{array}$ & $\begin{array}{l}\text { Ethiopie } \\
\text { Tchad } \\
\text { Somalie } \\
\text { Mauritanie } \\
\text { Libéria } \\
\end{array}$ & $\begin{array}{l}19 \\
37 \\
66 \\
55\end{array}$ & $\begin{array}{l}70 \\
50 \\
67 \\
93 \\
\end{array}$ & $\begin{array}{l}11 \\
29 \\
65 \\
22\end{array}$ & $\begin{array}{l}46 \\
30 \\
27 x \\
40 \\
39 \\
\end{array}$ & $\begin{array}{l}. \\
50^{x} \\
50\end{array}$ & $\begin{array}{l}\cdot \cdot \\
15^{x} \\
30\end{array}$ & $\begin{array}{r}10 / 57 \\
\quad / 59 \\
3 / 31 \\
57 / 75 \\
87 / 62^{x} \\
\end{array}$ & $\begin{array}{c}6 / 44 \\
.20 \\
2 / 18 \\
18 / 28 \\
39 / 28^{x} \\
\end{array}$ & $\begin{array}{c}7 / 44 \\
. / 20 \\
2 / 18 \\
18 / 28 \\
26 / 28^{x} \\
\end{array}$ & $\begin{array}{c}7 / 37 \\
1 / 32 \\
3 / 30 \\
45 / 33 \\
99 / 55^{x} \\
\end{array}$ & $\begin{array}{r}. / 43 \\
. / 42 \\
5 / 5 \\
1 / 40 \\
60 / 20^{x}\end{array}$ \\
\hline $\begin{array}{l}16 \\
17 \\
18 \\
19 \\
20 \\
\end{array}$ & $\begin{array}{l}\text { Rwanda } \\
\text { Cambodge } \\
\text { Burundi } \\
\text { Bhoutan } \\
\text { Népal } \\
\end{array}$ & $\begin{array}{c}50^{x} \\
3^{x} \\
38 \\
32 \\
37 \\
\end{array}$ & $\begin{array}{r}79^{x} \\
10^{x} \\
100 \\
60 \\
66 \\
\end{array}$ & $\begin{array}{c}48^{x} \\
2^{x} \\
34 \\
30 \\
34 \\
\end{array}$ & $\begin{array}{l}27^{x} \\
53 \\
61 \\
65 \\
\end{array}$ & $\begin{array}{l}40^{x} \\
80 \\
. \\
. \\
. \\
\end{array}$ & $\begin{array}{l}25^{x} \\
50 \\
. . \\
. \cdot \\
. \\
\end{array}$ & $\begin{array}{r}51 / 92 \\
1 / 54 \\
65 / 97 \\
36 / 99 \\
32 / 97 \\
\end{array}$ & $\begin{array}{r}17 / 84 \\
1 / 40 \\
38 / 86 \\
13 / 95 \\
16 / 79 \\
\end{array}$ & $\begin{array}{r}15 / 83 \\
. / 40 \\
6 / 86 \\
11 / 95 \\
1 / 78 \\
\end{array}$ & $\begin{array}{r}42 / 83 \\
. / 34 \\
30 / 75 \\
21 / 89 \\
2 / 67 \\
\end{array}$ & $\begin{array}{r}5 / 87 \\
. / . \\
25 / 56 \\
. / 63 \\
4 / 28 \\
\end{array}$ \\
\hline $\begin{array}{l}21 \\
22 \\
23 \\
24 \\
25 \\
\end{array}$ & $\begin{array}{l}\text { Yémen } \\
\text { Sénégal } \\
\text { Bangladesh } \\
\text { Madagascar } \\
\text { Soudan } \\
\end{array}$ & $\begin{array}{l}38^{x} \\
54^{x} \\
81 \\
22 \\
46 \\
\end{array}$ & $\begin{array}{l}56^{x} \\
79^{x} \\
39 \\
62 \\
56 \\
\end{array}$ & $\begin{array}{l}30^{x} \\
38^{x} \\
89 \\
10 \\
43 \\
\end{array}$ & $\begin{array}{l}38 \\
40 \\
45 \\
56 \\
51\end{array}$ & $\begin{array}{l}\cdots \\
\cdots \\
90\end{array}$ & $\begin{array}{l}\cdots \\
\cdots \\
40\end{array}$ & $\begin{array}{r}14 / 71 \\
\cdot / 92 \\
1 / 86 \\
25 / 67 \\
3 / 73 \\
\end{array}$ & $\begin{array}{r}21 / 53 \\
\cdot / 60 \\
1 / 62 \\
40 / 46 \\
1 / 62 \\
\end{array}$ & $\begin{array}{r}21 / 53 \\
. / 66 \\
1 / 62 \\
. \quad / 46 \\
1 / 62 \\
\end{array}$ & $\begin{array}{r}33 / 45 \\
. / 59 \\
. / 54 \\
\cdot / 33 \\
1 / 57 \\
\end{array}$ & $\begin{array}{r}/ 8 \\
. / 45 \\
1 / 74 \\
. / 60 \\
1 / 14 \\
\end{array}$ \\
\hline $\begin{array}{l}26 \\
27 \\
28 \\
29 \\
30\end{array}$ & $\begin{array}{l}\text { Tanzanie, Rép.-Unie de } \\
\text { Rép. centrafricaine } \\
\text { Namibie } \\
\text { Nigéria } \\
\text { Gabon } \\
\end{array}$ & $\begin{array}{l}56 \\
12 \\
. \\
. \\
68 \\
\end{array}$ & $\begin{array}{l}75 \\
13 \\
\cdots \\
90\end{array}$ & $\begin{array}{l}46 \\
11 \\
54 \\
50\end{array}$ & $\begin{array}{l}76^{x} \\
45 \\
66 \\
90^{x}\end{array}$ & $\begin{array}{l}99^{x} \\
\therefore \\
85 \\
.\end{array}$ & $\begin{array}{l}72^{x} \\
\cdot \dot{ } \\
62 \\
.\end{array}$ & $\begin{array}{r}78 / 93 \\
. \quad 196 \\
.185 \\
23 / 96 \\
. \quad / 96\end{array}$ & $\begin{array}{r}58 / 85 \\
. \quad / 82 \\
. \quad / 53 \\
24 / 57 \\
. \quad / 78\end{array}$ & $\begin{array}{r}49 / 82 \\
. \quad / 82 \\
. \quad / 53 \\
24 / 57 \\
. \quad .78\end{array}$ & $\begin{array}{r}76 / 83 \\
. / 82 \\
. / 41 \\
55 / 54 \\
.76\end{array}$ & $\begin{array}{r}36 / 42 \\
. / 87 \\
. / 50 \\
11 / 58 \\
. \quad / 86\end{array}$ \\
\hline $\begin{array}{l}31 \\
32 \\
33 \\
34 \\
35\end{array}$ & $\begin{array}{l}\text { Ouganda } \\
\text { Balivie } \\
\text { Pakistan } \\
\text { Rép.dém.pop.lao } \\
\text { Cameroun }\end{array}$ & $\begin{array}{l}21 \\
53 \\
56 \\
29 \\
44\end{array}$ & $\begin{array}{l}43 \\
77 \\
80 \\
47 \\
50\end{array}$ & $\begin{array}{l}18 \\
27 \\
45 \\
25 \\
39\end{array}$ & $\begin{array}{l}61^{x} \\
63 \\
55 \\
67 \\
41\end{array}$ & $\begin{array}{l}90 x \\
90 \\
99 \\
44 \\
\end{array}$ & $\begin{array}{l}57^{x} \\
36 \\
35 \\
39 \\
\end{array}$ & $\begin{array}{r}18 / 99 \\
30 / 48 \\
11 / 98 \\
4 / 26 \\
8 / 76\end{array}$ & $\begin{array}{r}9 / 77 \\
13 / 41 \\
3 / 96 \\
7 / 18 \\
5 / 56 \\
\end{array}$ & $\begin{array}{r}8 / 77 \\
15 / 50 \\
3 / 96 \\
7 / 26 \\
5 / 54\end{array}$ & $\begin{array}{r}22 / 74 \\
17 / 53 \\
2 / 97 \\
7 / 13 \\
16 / 56 \\
\end{array}$ & $\begin{array}{r}20 / 31 \\
. / 20 \\
1 / 87 \\
2 / 10 \\
. \quad / 63 \\
\end{array}$ \\
\hline \multirow[t]{2}{*}{$\begin{array}{l}36 \\
37 \\
38\end{array}$} & $\begin{array}{l}\text { Bénin } \\
\text { Togo } \\
\text { Inde }\end{array}$ & $\begin{array}{l}54 \\
71 \\
75\end{array}$ & $\begin{array}{r}66 \\
100 \\
79\end{array}$ & $\begin{array}{l}46 \\
61 \\
73\end{array}$ & 61 & $\begin{array}{l}. \dot{ } \\
. \\
.\end{array}$ & $\begin{array}{l}\cdot \dot{ } \\
. \\
.\end{array}$ & $\begin{array}{r}J / 92 \\
44 / 94 \\
12 / 97\end{array}$ & $\begin{array}{r}/ 67 \\
9 / 61 \\
31 / 92\end{array}$ & $\begin{array}{l}. / 67 \\
9 / 61 \\
7 / 93\end{array}$ & $\begin{array}{r}.770 \\
47 / 57 \\
. / 87\end{array}$ & $\begin{array}{r}. / 83 \\
57 / 81 \\
24 / 77\end{array}$ \\
\hline & $\begin{array}{l}\text { Pays TMM5 elevo } \\
(71-140) \\
\text { Mediene }\end{array}$ & 61 & 85 & 41 & 75 & 97 & 50 & $61 / 83$ & 4275 & $42 / 76$ & $33 / 73$ & $10 / 48$ \\
\hline $\begin{array}{l}39 \\
40 \\
41 \\
42 \\
43 \\
\end{array}$ & $\begin{array}{l}\text { Ghana } \\
\text { Côte d'Ivoire } \\
\text { Haîti } \\
\text { Zaïre } \\
\text { Lesotho } \\
\end{array}$ & $\begin{array}{l}57 \\
.5 \\
36 \\
33 \\
48 \\
\end{array}$ & $\begin{array}{l}93 \\
59 \\
59 \\
59 \\
\end{array}$ & $\begin{array}{l}39 \\
27 \\
17 \\
45 \\
\end{array}$ & $\begin{array}{l}60 \\
30^{x} \\
50 \\
26 \\
80 \\
\end{array}$ & $\begin{array}{l}92 \\
61^{x} \\
40 \\
. \\
\end{array}$ & $\begin{array}{l}45 \\
11^{x} \\
.17 \\
. \\
\end{array}$ & $\begin{array}{l}67 / 81 \\
70 / 63 \\
60 / 72 \\
34 / 65 \\
81 / 97 \\
\end{array}$ & $\begin{array}{l}22 / 57 \\
42 / 48 \\
14 / 41 \\
18 / 32 \\
56 / 76 \\
\end{array}$ & $\begin{array}{r}25 / 56 \\
34 / 48 \\
3 / 40 \\
18 / 31 \\
54 / 75 \\
\end{array}$ & $\begin{array}{r}23 / 60 \\
28 / 42 \\
1 / 31 \\
23 / 31 \\
49 / 76 \\
\end{array}$ & $\begin{array}{l}11 / 33 \\
25 / 63 \\
. \quad / 23 \\
. . / 29 \\
. \quad . / . \\
\end{array}$ \\
\hline $\begin{array}{l}44 \\
45 \\
46 \\
47 \\
48 \\
\end{array}$ & $\begin{array}{l}\text { Zambie } \\
\text { Pérou } \\
\text { Jamahiriya arabe libyenne } \\
\text { Maroc } \\
\text { Congo }\end{array}$ & $\begin{array}{l}60 \\
61 \\
94 \\
61 \\
38 \\
\end{array}$ & $\begin{array}{r}76 \\
78 \\
100 \\
100 \\
92 \\
\end{array}$ & $\begin{array}{r}43 \\
22 \\
80 \\
25 \\
2\end{array}$ & $\begin{array}{l}75^{x} \\
75^{x} \\
70 \\
83 \\
\end{array}$ & $\begin{array}{r}100^{x} \\
100 \\
97\end{array}$ & $\begin{array}{l}50^{x} \\
\cdots \\
50 \\
70\end{array}$ & $\begin{array}{r}72 / 97 \\
63 / 83 \\
55 / 90 \\
.196 \\
92 / 90 \\
\end{array}$ & $\begin{array}{l}44 / 79 \\
18 / 72 \\
55 / 84 \\
43 / 81 \\
42 / 79 \\
\end{array}$ & $\begin{array}{l}77 / 78 \\
18 / 73 \\
55 / 84 \\
45 / 81 \\
42 / 79 \\
\end{array}$ & $\begin{array}{l}21 / 76 \\
24 / 64 \\
57 / 70 \\
4 \quad 79 \\
49 / 75 \\
\end{array}$ & $\begin{array}{l}. / 68 \\
4 / 9 \\
6 / 6 \\
.64 \\
.660 \\
\end{array}$ \\
\hline $\begin{array}{l}49 \\
50 \\
51 \\
52 \\
53\end{array}$ & $\begin{array}{l}\text { Kenya } \\
\text { Algérie } \\
\text { Indonésie } \\
\text { Guatemaia } \\
\text { Arabie saoudite }\end{array}$ & $\begin{array}{l}31^{x} \\
71^{x} \\
46 \\
61 \\
94\end{array}$ & $\begin{array}{r}61^{x} \\
85^{x} \\
60 \\
91 \\
100\end{array}$ & $\begin{array}{l}21^{x} \\
55^{x} \\
40 \\
41 \\
74\end{array}$ & $\begin{array}{l}88 \\
80 \\
34 \\
97\end{array}$ & $\begin{array}{r}100 \\
47 \\
100\end{array}$ & $\begin{array}{l}80 \\
25 \\
88\end{array}$ & $\begin{array}{r}. / 80 \\
59 / 99 \\
55 / 93 \\
29 / 62 \\
49 / 99\end{array}$ & $\begin{array}{r}.774 \\
33 / 89 \\
. / 87 \\
42 / 66 \\
53 / 94\end{array}$ & $\begin{array}{r}.771 \\
30 / 89 \\
.191 \\
42 / 74 \\
52 / 94\end{array}$ & $\begin{array}{r}. / 59 \\
17 / 83 \\
. / 86 \\
8 / 68 \\
12 / 90\end{array}$ & $\begin{array}{r}. / 37 \\
. / 27 \\
10 / 41 \\
1 / 48 \\
. \quad .62\end{array}$ \\
\hline $\begin{array}{l}54 \\
55 \\
56 \\
57 \\
58\end{array}$ & $\begin{array}{l}\text { Alrique du Sud } \\
\text { Myanmar } \\
\text { El Salvador } \\
\text { Zimbabwe } \\
\text { Irag }\end{array}$ & $\begin{array}{l}33 \\
48 \\
66 \\
92\end{array}$ & $\begin{array}{r}43 \\
84 \\
31 \\
100\end{array}$ & $\begin{array}{l}29 \\
19 \\
80 \\
72\end{array}$ & $\begin{array}{l}33 \\
56 \\
71 \\
93\end{array}$ & $\begin{array}{r}100 \\
80 \\
100 \\
97\end{array}$ & $\begin{array}{l}11 \\
40 \\
62 \\
78\end{array}$ & $\begin{array}{r}1 / 85 \\
15 / 66 \\
47 / 60 \\
64 / 71 \\
76 / 96\end{array}$ & $\begin{array}{r}. / 67 \\
5 / 61 \\
42 / 76 \\
39 / 73 \\
13 / 75 \\
\end{array}$ & $\begin{array}{r}. / 69 \\
. / 61 \\
38 / 76 \\
38 / 72 \\
16 / 75\end{array}$ & $\begin{array}{r}. / 63 \\
. \quad / 44 \\
44 / 75 \\
56 / 69 \\
33 / 62\end{array}$ & $\begin{array}{r}. / . \\
6 / 56 \\
20 / 12 \\
. / 60 \\
4 / 67\end{array}$ \\
\hline $\begin{array}{l}59 \\
60 \\
61 \\
62 \\
63\end{array}$ & $\begin{array}{l}\text { Egypte } \\
\text { Botswana } \\
\text { Turquie } \\
\text { Mongolie } \\
\text { Honduras }\end{array}$ & $\begin{array}{l}73^{x} \\
54^{x} \\
78^{x} \\
65 \\
73\end{array}$ & $\begin{array}{l}92^{x} \\
84^{x} \\
95^{x} \\
78 \\
89\end{array}$ & $\begin{array}{l}56^{x} \\
46^{x} \\
63^{x} \\
50 \\
60\end{array}$ & $\begin{array}{l}89^{x} \\
66\end{array}$ & $\begin{array}{c}100^{x} \\
80\end{array}$ & $\begin{array}{l}85^{x} \\
- \\
56\end{array}$ & $\begin{array}{l}71 / 88 \\
80 / 92 \\
42 / \\
53 / 92 \\
46 / 71\end{array}$ & $\begin{array}{l}82 / 87 \\
64 / 86 \\
64 / 74 \\
99 / 84 \\
38 / 84\end{array}$ & $\begin{array}{l}84 / 87 \\
71 / 82 \\
69 / 74 \\
99 / 85 \\
37 / 87\end{array}$ & $\begin{array}{r}65 / 86 \\
68 / 78 \\
52 / 67 \\
. / 86 \\
38 / 90\end{array}$ & $\begin{array}{l}10 / 63 \\
32 / 62 \\
. / 15 \\
. / . \\
11 / 51\end{array}$ \\
\hline
\end{tabular}




\begin{tabular}{|c|c|c|c|c|c|c|c|c|c|}
\hline & & \multicolumn{2}{|c|}{$\begin{array}{l}\text { Adull literacy } \\
\text { rate }\end{array}$} & \multirow{2}{*}{$\begin{array}{c}\text { No. of radio/ } \\
\text { television } \\
\text { receivers } \\
\text { per } 1,000 \\
\text { population } \\
1985\end{array}$} & \multicolumn{3}{|c|}{$\begin{array}{l}\text { Primary-school } \\
\text { enrolment ratio }\end{array}$} & \multirow{2}{*}{$\begin{array}{l}\text { \% of grade } 1 \\
\text { enrolment } \\
\text { compieting } \\
\text { primary } \\
\text { school } \\
1980-86\end{array}$} & \multirow{2}{*}{$\begin{array}{c}\text { Secondary-schoo } \\
\text { enrolment ratio } \\
1983-86 \\
\text { male/lemale }\end{array}$} \\
\hline & & $\begin{array}{c}1970 \\
\text { male/lemaie }\end{array}$ & $\begin{array}{c}1985 \\
\text { male/lemale }\end{array}$ & & $\begin{array}{l}1960 \text { (gross) } \\
\text { male/temale }\end{array}$ & $\begin{array}{c}1983-86 \text { (gross) } \\
\text { male/temale }\end{array}$ & $\begin{array}{c}1983-86 \text { (net) } \\
\text { male/fermale }\end{array}$ & & \\
\hline & $\begin{array}{l}\text { Very high U5MR } \\
\text { countries (over 170) } \\
\text { Modian }\end{array}$ & $25 / 8$ & $43 / 22$ & $58 / 4$ & $28 / 13$ & $71 / 48$ & $53 / 40$ & 41 & $18 / 6$ \\
\hline $\begin{array}{l}1 \\
2 \\
3 \\
4 \\
5 \\
\end{array}$ & $\begin{array}{l}\text { Afghanistan } \\
\text { Mali } \\
\text { Sierra Leone } \\
\text { Malawi } \\
\text { Ethiopia } \\
\end{array}$ & $\begin{array}{c}13 / 2 \\
11 / 4 \\
18 / 8 \\
42 / 18 \\
8 / 1 \\
\end{array}$ & $\begin{array}{l}39 / 8 \\
23 / 11 \\
38 / 21 \\
52 / 31 \\
.\end{array}$ & $\begin{array}{l}91 / 6 \\
16 /(.) \\
222 / 8 \\
245 / . \\
184 / 2\end{array}$ & $\begin{array}{l}15 / 2 \\
14 / 6 \\
30 / 15 \\
1 / 45 \\
11 / 3\end{array}$ & $\begin{array}{c}24 / 11 \\
29 / 17 \\
68^{x} / 48^{x} \\
71 / 53 \\
44 / 28\end{array}$ & $\begin{array}{l}20 / 10 \\
4 / \% \\
47 / 41 \\
\%\end{array}$ & $\begin{array}{l}54 \\
25^{*} \\
48^{y} \\
28 \\
41^{*}\end{array}$ & $\begin{array}{c}11 / 5 \\
10 / 4 \\
23 x / 11 x \\
6 / 2 \\
14 / 9\end{array}$ \\
\hline $\begin{array}{r}6 \\
7 \\
8 \\
9 \\
10 \\
\end{array}$ & $\begin{array}{l}\text { Guinea } \\
\text { Somalia } \\
\text { Mozambique } \\
\text { Burkina Faso } \\
\text { Angola } \\
\end{array}$ & $\begin{array}{l}21 / 7 \\
5 / 1 \\
29 / 14 \\
13 / 3 \\
16 / 7 \\
\end{array}$ & $\begin{array}{l}40 / 17 \\
18 / 6 \\
55 / 22 \\
21 / 6 \\
49 \% \\
\end{array}$ & $\begin{array}{l}30 / 1 \\
43 / . .) \\
32 /(.) \\
21 / 5 \\
26 / 5 \\
\end{array}$ & $\begin{array}{l}44 / 16 \\
13 / 5 \\
60 / 36 \\
12 / 5 \\
. .1 \\
\end{array}$ & $\begin{array}{c}42 / 19 \\
32 / 18 \\
94 / 74 \\
41 / 24 \\
146^{x} / 121^{x} \\
\end{array}$ & $\begin{array}{l}33 / 15 \\
53 / 45 \\
53 / 40 \\
71^{x} / 61^{x} \\
\end{array}$ & $\begin{array}{l}37 \\
33^{*} \\
26 \\
75 \\
24\end{array}$ & $\begin{array}{c}18 / 6 \\
23 / 12 \\
9 / 4 \\
7 / 3 \\
\%\end{array}$ \\
\hline $\begin{array}{l}11 \\
12 \\
13 \\
14 \\
15 \\
\end{array}$ & $\begin{array}{l}\text { Niger } \\
\text { Chad } \\
\text { Guinea-Bissau } \\
\text { Central African Rep. } \\
\text { Senegal }\end{array}$ & $\begin{array}{l}6 / 2 \\
20 / 2 \\
13 / 6 \\
26 / 6 \\
18 / 5 \\
\end{array}$ & $\begin{array}{l}19 / 9 \\
40 / 11 \\
46 / 17 \\
53 / 29 \\
37 / 19 \\
\end{array}$ & $\begin{array}{r}49 / 2 \\
219 / \% \\
34 \% \\
58 / 2 \\
109 / 31 \\
\end{array}$ & $\begin{array}{l}7 / 3 \\
29 / 4 \\
35 / 15 \\
53 / 12 \\
36 / 17 \\
\end{array}$ & $\begin{array}{c}37 / 20 \\
55 / 21 \\
81 / 40 \\
98^{x} / 51^{x} \\
66 / 45 \\
\end{array}$ & $\begin{array}{c}1 / \\
71 / 35 \\
79^{x} / 42^{x} \\
52 / 36 \\
\end{array}$ & $\begin{array}{l}67 y \\
29 y \\
18 \\
53 \\
86 \\
\end{array}$ & $\begin{array}{c}9 / 3 \\
11 / 2 \\
18 / 4 \\
24^{x} / 8^{x} \\
18 / 9\end{array}$ \\
\hline $\begin{array}{l}16 \\
17 \\
18 \\
19 \\
20 \\
\end{array}$ & $\begin{array}{l}\text { Mauritania } \\
\text { Liberia } \\
\text { Rwanda } \\
\text { Kampuchea } \\
\text { Yemen } \\
\end{array}$ & $\begin{array}{l}27 / 8 \\
43 / 21 \\
. / 23 \\
9 / 1 \\
\end{array}$ & $\begin{array}{c}47 / 23 \\
61 / 33 \\
85^{\circ} / 65^{\circ} \\
27 / 3 \\
\end{array}$ & $\begin{array}{r}132 /(.) \\
228 / 16 \\
58 / . \\
110 / 7 \\
22 / 4 \\
\end{array}$ & $\begin{array}{l}13 / 3 \\
45 / 18 \\
68 / 30 \\
14 \% \\
\end{array}$ & $\begin{array}{c}45^{x} / 29^{x} \\
82^{*} / 50^{*} \\
66 / 63 \\
100^{*} / 80^{*} \\
112 / 22 \\
\end{array}$ & $\begin{array}{l}\% \\
62 / 60 \\
\% \\
\%\end{array}$ & $\begin{array}{l}80 \\
47 \\
50^{*} \\
15^{*}\end{array}$ & $\begin{array}{c}19^{x} / 6^{x} \\
33^{x} / 13^{x} \\
3 / 2 \\
45^{*} / 20^{*} \\
17 / 3\end{array}$ \\
\hline $\begin{array}{l}21 \\
22 \\
23 \\
24 \\
25 \\
\end{array}$ & $\begin{array}{l}\text { Yemen, Dem. } \\
\text { Bhutan } \\
\text { Nepal } \\
\text { Burundi } \\
\text { Bangladesh } \\
\end{array}$ & $\begin{array}{l}31 / 9 \\
23 / 1 / 3 \\
29 / 10 \\
36 / 12 \\
\end{array}$ & $\begin{array}{c}59 / 25 \\
39 / 112 \\
43^{x} / 126^{x} \\
43 / 22 \\
\end{array}$ & $\begin{array}{l}70 / 18 \\
14 / . \\
30 / 1 \\
53 / 4 \\
40 / 3 \\
\end{array}$ & $\begin{array}{l}20 / 5 \\
5 / / 1 \\
19 / 1 \\
27 / 9 \\
66 / 26\end{array}$ & $\begin{array}{r}96 / 35 \\
32 / 18 \\
80^{\circ} / 44^{*} \\
61 / 44 \\
70 / 50 \\
\end{array}$ & $\begin{array}{l}5 / 1 / 29 * \\
47 / 35 \\
63 / 45\end{array}$ & $\begin{array}{l}40^{*} \\
25^{y} \\
27^{*} \\
94 \\
20\end{array}$ & $\begin{array}{c}26 / 11 \\
6 / 1 \\
51^{*} / 19 * \\
5 / 3 \\
26 / 10\end{array}$ \\
\hline $\begin{array}{l}26 \\
27 \\
28 \\
29 \\
\end{array}$ & $\begin{array}{l}\text { Benin } \\
\text { Sudan } \\
\text { Tanzania, U. Rep. of } \\
\text { Bolivia }\end{array}$ & $\begin{array}{l}23 / 8 \\
28 / 6 \\
48 / 18 \\
68 / 46 \\
\end{array}$ & $\begin{array}{c}37 / 16 \\
33^{y} / 14^{y} \\
93^{y} / 88^{y} \\
84 / 65\end{array}$ & $\begin{array}{r}74 / 4 \\
251 / 51 \\
89 /(.) \\
581 / 66 \\
\end{array}$ & $\begin{array}{l}38 / 15 \\
35 / 14 \\
33 / 18 \\
78 / 50\end{array}$ & $\begin{array}{c}87 / 43 \\
57^{\circ} / 49^{*} \\
79^{*} / 81^{*} \\
96 / 85\end{array}$ & $\begin{array}{c}68 / 34 \\
66^{\circ} / 68^{*} \\
86 / 77 \\
\end{array}$ & $\begin{array}{l}15^{\circ} \\
61^{*} \\
76 \\
32^{y} \\
\end{array}$ & $\begin{array}{c}29 / 12 \\
190^{*} / 13^{*} \\
53^{*} \\
40 / 34 \\
\end{array}$ \\
\hline \multirow[t]{2}{*}{$\begin{array}{l}30 \\
31 \\
32 \\
33 \\
\end{array}$} & $\begin{array}{l}\text { Nigeria } \\
\text { Haiti } \\
\text { Gabon } \\
\text { Uganda } \\
\end{array}$ & $\begin{array}{l}35 / 14 \\
26 / 17 \\
43 / 22 \\
52 / 30 \\
\end{array}$ & $\begin{array}{l}54 / 31 \\
40 / 35 \\
70 / 53 \\
70 / 45 \\
\end{array}$ & $\begin{array}{l}85 / 5 \\
21 / 3 \\
96 / 19 \\
22 / 6 \\
\end{array}$ & $\begin{array}{l}46 / 27 \\
50 / 42 \\
.1 / 32 \\
\end{array}$ & $\begin{array}{c}103 / 81 \\
83 / 72 \\
124 / 121 \\
66^{x} / 50^{x} \\
\end{array}$ & $\begin{array}{l}45 / 42 \\
43 / 38 x\end{array}$ & $\begin{array}{l}31^{*} \\
45^{y} \\
59 \\
58^{y}\end{array}$ & $\begin{array}{l}19 / 117 \\
30 / 20 \\
11^{x} / 5^{x}\end{array}$ \\
\hline & $\begin{array}{l}\text { High U5MR countries } \\
\text { (95-170) } \\
\text { Median }\end{array}$ & $48 / 20$ & $68 / 50$ & $133 / 52$ & $68 / 38$ & $105 / 92$ & 88/81 & 68 & $45 / 29$ \\
\hline $\begin{array}{l}34 \\
35 \\
36 \\
37 \\
38 \\
\end{array}$ & $\begin{array}{l}\text { Pakistan } \\
\text { Zaire } \\
\text { Lao People's Dem. Rep. } \\
\text { Oman } \\
\text { Iran (Islamic Rep. of) } \\
\end{array}$ & $\begin{array}{l}30 / 11 \\
61 / 22 \\
37 / 28 \\
40 / 17 \\
\end{array}$ & $\begin{array}{c}40 / 19 \\
79 / 45 \\
92 / 76 \\
477^{y} / 12^{y} \\
62 / 39 \\
\end{array}$ & $\begin{array}{l}90 / 13 \\
100 /(.) \\
104 / . \\
644 / 725 \\
224 / 56 \\
\end{array}$ & $\begin{array}{l}46 / 13 \\
88 / 32 \\
34 / 16 \\
. / . \\
56 / 27 \\
\end{array}$ & $\begin{array}{c}66^{*} / 33^{*} \\
112 / 84 \\
101 / 79 \\
97 / 80 \\
122 / 101 \\
\end{array}$ & $\begin{array}{l}86 / 65 \\
80 / 74 \\
98 / 86\end{array}$ & $\begin{array}{l}34^{*} \\
65^{y} \\
14^{*} \\
60^{y} \\
70^{x} \\
\end{array}$ & $\begin{array}{l}21 * / 8 * \\
81 / 33 \\
23 / 15 \\
43 / 21 \\
54 / 37 \\
\end{array}$ \\
\hline $\begin{array}{l}39 \\
40 \\
41 \\
42 \\
43 \\
\end{array}$ & $\begin{array}{l}\text { Cameroon } \\
\text { Togo } \\
\text { India } \\
\text { Cóte d'Ivoire } \\
\text { Ghana } \\
\end{array}$ & $\begin{array}{l}47 / 19 \\
27 / 7 \\
47 / 20 \\
26 / 10 \\
43 / 18 \\
\end{array}$ & $\begin{array}{l}68 / 55 \\
53 / 28 \\
57 / 29 \\
53 / 31 \\
64 / 43 \\
\end{array}$ & $\begin{array}{r}95 / 1 \\
206 / 5 \\
66 / 5 \\
133 / 51 \\
184 / 10 \\
\end{array}$ & $\begin{array}{l}87 / 43 \\
63 / 24 \\
80 / 40 \\
69 / 24 \\
52 / 25 \\
\end{array}$ & $\begin{array}{r}116 / 97 \\
118 / 73 \\
107 / 76 \\
92 / 65 \\
75 / 59 \\
\end{array}$ & $\begin{array}{l}\% \\
\% \\
\% \\
\%\end{array}$ & $\begin{array}{l}70^{*} \\
43 \\
38^{y} \\
89^{y} \\
75^{y} \\
\end{array}$ & $\begin{array}{l}29 / 18 \\
33 / 10 \\
45 / 24 \\
27 / 12 \\
45 / 27 \\
\end{array}$ \\
\hline $\begin{array}{l}44 \\
45 \\
46 \\
47 \\
48 \\
\end{array}$ & $\begin{array}{l}\text { Lesotho } \\
\text { Zambia } \\
\text { Egypt } \\
\text { Peru } \\
\text { Libyan Arab Jamahiriya } \\
\end{array}$ & $\begin{array}{l}49 / 74 \\
66 / 37 \\
50 / 20 \\
81 / 60 \\
60 / 13 \\
\end{array}$ & $\begin{array}{l}62 / 84 \\
84 / 67 \\
59 / 30 \\
91 / 78 \\
81 / 50 \\
\end{array}$ & $\begin{array}{r}28 /(.) \\
30 / 14 \\
256 / 82 \\
203 / 76 \\
222 / 65 \\
\end{array}$ & $\begin{array}{l}63 / 102 \\
51 / 34 \\
80 / 52 \\
95 / 71 \\
92 / 24 \\
\end{array}$ & $\begin{array}{c}102 / 127 \\
106 / 96 \\
94 / 76 \\
125 / 120 \\
. .1 \\
\end{array}$ & $\begin{array}{l}8{ }^{\prime} / 84 \\
.1 / \\
.1 / \\
.1 \\
\end{array}$ & $\begin{array}{l}27^{*} \\
85 \\
64 \\
51^{*} \\
82\end{array}$ & $\begin{array}{l}18 / 26 \\
23 / 13 \\
73 / 52 \\
68 / 61 \\
\ldots .\end{array}$ \\
\hline $\begin{array}{l}49 \\
50 \\
51 \\
52 \\
53\end{array}$ & $\begin{array}{l}\text { Morocco } \\
\text { Indonesia } \\
\text { Congo } \\
\text { Kenya } \\
\text { Zimbabwe }\end{array}$ & $\begin{array}{l}34 / 10 \\
66 / 42 \\
50 / 19 \\
44 / 19 \\
63 / 47 \\
\end{array}$ & $\begin{array}{l}45 / 22 \\
83 / 65 \\
71 / 55 \\
70 / 49 \\
81 / 67 \\
\end{array}$ & $\begin{array}{r}175 / 52 \\
117 / 39 \\
115 / 3 \\
78 / 5 \\
43 / 14 \\
\end{array}$ & $\begin{array}{r}67 / 27 \\
86 / 58 \\
103 / 53 \\
64 / 30 \\
.1 \%\end{array}$ & $\begin{array}{c}98 / 63 \\
121 / 116 \\
97 / 91 \\
132 / 126\end{array}$ & $\begin{array}{r}76 / 50 \\
100 / 96 \\
\cdots \% \\
\% \\
\% \\
\end{array}$ & $\begin{array}{l}70^{\circ} \\
80^{*} \\
74 \\
62 \\
79^{*} \\
\end{array}$ & $\begin{array}{l}38 / 25 \\
45 / 34 \\
25 / 16 \\
56 / 38 \\
\end{array}$ \\
\hline $\begin{array}{l}54 \\
55 \\
56 \\
57 \\
58 \\
\end{array}$ & $\begin{array}{l}\text { Honduras } \\
\text { Algeria } \\
\text { Tunisia } \\
\text { Guatemala } \\
\text { Saudi Arabia } \\
\end{array}$ & $\begin{array}{l}55 / 50 \\
39 / 11 \\
44 / 17 \\
51 / 37 \\
15 / 2 \\
\end{array}$ & $\begin{array}{l}61 / 58 \\
63 / 37 \\
68 / 41 \\
63 / 47 \\
35^{x} / 12^{x} \\
\end{array}$ & $\begin{array}{c}366 / 64 \\
221 / 72 \\
219 / 56 \\
44 / 26 \\
321 / 269 \\
\end{array}$ & $\begin{array}{l}68 / 67 \\
55 / 37 \\
88 / 43 \\
50 / 39 \\
22 / 2 \\
\end{array}$ & $\begin{array}{c}103 / 102 \\
104 / 83 \\
127 / 108 \\
77 / 61 \\
\end{array}$ & $\begin{array}{r}95 / 78 \\
100 / 89 \\
63 / 46 \\
\end{array}$ & $\begin{array}{l}27^{\circ} \\
83^{*} \\
78 \\
38 \\
79\end{array}$ & $\begin{array}{l}\% \\
46 / 33 \\
51 / 33\end{array}$ \\
\hline $\begin{array}{l}59 \\
60 \\
61 \\
62 \\
63 \\
64\end{array}$ & $\begin{array}{l}\text { South Africa } \\
\text { Nicaragua } \\
\text { Turkey } \\
\text { lraq } \\
\text { Botswana } \\
\text { Viet Nam }\end{array}$ & $\begin{array}{l}5 \% / 157 \\
69 / 35 \\
50 / 18 \\
37 / 44 \\
. .1 .\end{array}$ & $\begin{array}{c}1 / \\
86^{x} / 62^{x} \\
90 / 87 \\
73 / 69 \\
88^{\circ} / 80^{\circ}\end{array}$ & $\begin{array}{l}309 / 93 \\
244 / 58 \\
130 / 148 \\
189 / 57 \\
126 / \% \\
100 / 33\end{array}$ & $\begin{array}{l}94 / 85 \\
65 / 66 \\
90 / 58 \\
94 / 36 \\
35 / 48 \\
.1 .\end{array}$ & $\begin{array}{c}/ / \\
119 / 112 \\
108 / 92 \\
98 / 109 \\
107 / 94\end{array}$ & $\begin{array}{l}\ldots / \\
92 / 81 \\
83 / 93 \\
\ldots \%\end{array}$ & $\begin{array}{l}27 \\
85^{\circ} \\
65^{\circ} \\
80^{*} \\
50^{\circ}\end{array}$ & $\begin{array}{l}\% \\
53 / 31 \\
69 / 39 \\
27 / 31 \\
44 / 41\end{array}$ \\
\hline
\end{tabular}

Note: nations are listed in descending order of their 1986 under-five mortality rates (see table 1) 


\begin{tabular}{|c|c|c|c|c|c|c|c|c|c|c|c|c|c|c|c|c|}
\hline & & \multicolumn{4}{|c|}{$\begin{array}{l}\text { Taux d'alphabétisation } \\
\text { des adultes }\end{array}$} & \multirow{2}{*}{\multicolumn{2}{|c|}{$\begin{array}{l}\text { Postes } \\
\text { pouf } 1000 \\
\text { habilants } \\
1988\end{array}$}} & \multicolumn{6}{|c|}{ Taux d'inscription dans l'enseignement primaire } & \multirow{3}{*}{$\begin{array}{c}\text { Pourcentage } \\
\text { d'enfants } \\
\text { ayant accompii } \\
\text { la durég Iotale } \\
\text { de la scotarité } \\
\text { primaire } \\
1985-1987 \\
\end{array}$} & \multirow{2}{*}{\multicolumn{2}{|c|}{$\begin{array}{c}\text { Taux d'inscriptio } \\
\text { dans l'enseignem } \\
\text { secondaire } \\
\text { 1986-1989 (brut }\end{array}$}} \\
\hline & & \multicolumn{2}{|c|}{1970} & \multicolumn{2}{|c|}{ i990 } & & & \multicolumn{2}{|c|}{1960 (brut) } & \multicolumn{2}{|c|}{$1986-1989$ (brut) } & \multicolumn{2}{|c|}{$1986 \cdot 1989$ (net) } & & & \\
\hline & & Hommes & Femmes & Hommes & Femines & Radio & $\mathrm{N}$ & Garcons & Filles & Garçons & Filles & Garçons & Filles & & Garcons & Fille \\
\hline & $\begin{array}{l}\text { Paye a TMM5 très élevé } \\
\text { (supérieur à 140) } \\
\text { Médiane }\end{array}$ & 27 & 8 & 49 & 24 & 93 & 6 & 35 & 16 & 70 & 50 & 52 & 38 & 50 & 19 & 9 \\
\hline $\begin{array}{l}1 \\
2 \\
3 \\
4 \\
5\end{array}$ & $\begin{array}{l}\text { Mozambique } \\
\text { Afghanistan } \\
\text { Angola } \\
\text { Mali } \\
\text { Sierra Leone }\end{array}$ & $\begin{array}{l}29 \\
13 \\
16 \\
11 \\
18\end{array}$ & $\begin{array}{r}14 \\
2 \\
7 \\
4 \\
8\end{array}$ & $\begin{array}{l}45 \\
44 \\
56 \\
41 \\
31\end{array}$ & $\begin{array}{l}21 \\
14 \\
29 \\
24 \\
11\end{array}$ & $\begin{array}{r}39 \\
102 \\
50 \\
38 \\
218\end{array}$ & $\begin{array}{r}1 \\
8 \\
6 \\
9 \\
9\end{array}$ & $\begin{array}{l}60 \\
15 \\
14 \\
30\end{array}$ & $\begin{array}{r}36 \\
2 \\
. \\
6 \\
.\end{array}$ & $\begin{array}{r}76 \\
33 \\
101 \\
29 \\
65\end{array}$ & $\begin{array}{l}59 \\
17 \\
85 \\
17 \\
40\end{array}$ & $\begin{array}{l}49 \\
\cdots \\
23 \\
.\end{array}$ & $\begin{array}{l}41 \\
\cdots \\
14 \\
\cdots\end{array}$ & $\begin{array}{l}34 \\
78 \\
24 \\
40 \\
.\end{array}$ & $\begin{array}{r}7 \\
10 \\
17 \\
9 \\
23\end{array}$ & $\begin{array}{r}4 \\
7 \\
9 \\
4 \\
11\end{array}$ \\
\hline $\begin{array}{r}6 \\
7 \\
8 \\
9 \\
10\end{array}$ & $\begin{array}{l}\text { Malawi } \\
\text { Guinée-Bissau } \\
\text { Guinée } \\
\text { Burkina Faso } \\
\text { Niger }\end{array}$ & $\begin{array}{r}42 \\
13 \\
21 \\
13 \\
6\end{array}$ & $\begin{array}{r}18 \\
6 \\
7 \\
3 \\
2\end{array}$ & $\begin{array}{l}50 \\
35 \\
28 \\
40\end{array}$ & $\begin{array}{r}24 \\
13 \\
9 \\
17\end{array}$ & $\begin{array}{r}242 \\
38 \\
34 \\
25 \\
63\end{array}$ & $\begin{array}{l}\cdots \\
3 \\
5 \\
4\end{array}$ & $\begin{array}{r}\ldots \\
44 \\
12 \\
7\end{array}$ & $\begin{array}{r}45 \\
16 \\
16 \\
5 \\
3\end{array}$ & $\begin{array}{l}79 \\
69 \\
42 \\
41 \\
38\end{array}$ & $\begin{array}{l}65 \\
37 \\
19 \\
24 \\
21\end{array}$ & $\begin{array}{l}56 \\
52 \\
31 \\
34 \\
\cdots\end{array}$ & $\begin{array}{l}47 \\
29 \\
15 \\
20 \\
.\end{array}$ & $\begin{array}{l}31 \\
19 \\
43 \\
68 \\
75\end{array}$ & $\begin{array}{r}5 \\
9 \\
13 \\
8 \\
8\end{array}$ & $\begin{array}{l}3 \\
3 \\
4 \\
4 \\
3\end{array}$ \\
\hline $\begin{array}{l}11 \\
12 \\
13 \\
14 \\
15\end{array}$ & $\begin{array}{l}\text { Ethiopie } \\
\text { Tchad } \\
\text { Somalie } \\
\text { Mauritanie } \\
\text { Libéria }\end{array}$ & $\begin{array}{r}8 \\
20 \\
5 \\
27\end{array}$ & $\begin{array}{r}2 \\
1 \\
8 \\
8\end{array}$ & $\begin{array}{l}42 \\
27^{x} \\
47 \\
50\end{array}$ & $\begin{array}{l}18 \\
9^{x} \\
21 \\
29\end{array}$ & $\begin{array}{r}193 \\
235 \\
40 \\
143 \\
225\end{array}$ & $\begin{array}{r}2 \\
1 \\
0 \\
1 \\
18\end{array}$ & $\begin{array}{l}11 \\
29 \\
13 \\
13 \\
45\end{array}$ & $\begin{array}{r}3 \\
4 \\
13 \\
3 \\
18\end{array}$ & $\begin{array}{l}44 \\
73 \\
20 \\
61 \\
43\end{array}$ & $\begin{array}{l}28 \\
29 \\
10 \\
43 \\
24\end{array}$ & $\begin{array}{l}31 \\
52 \\
14 \\
. \\
.\end{array}$ & $\begin{array}{r}22 \\
23 \\
8 \\
\cdots \\
.\end{array}$ & $\begin{array}{l}50 \\
78 \\
33^{*} \\
78 \\
.\end{array}$ & $\begin{array}{l}18 \\
10 \\
23 \\
23 \\
.\end{array}$ & $\begin{array}{r}12 \\
2 \\
10 \\
10 \\
.\end{array}$ \\
\hline $\begin{array}{l}16 \\
17 \\
18 \\
19 \\
20 \\
\end{array}$ & $\begin{array}{l}\text { Rwanda } \\
\text { Cambodge } \\
\text { Burundi } \\
\text { Bhoutan } \\
\text { Népal } \\
\end{array}$ & $\begin{array}{l}43 \\
29 \\
23\end{array}$ & $\begin{array}{l}21 \\
10 \\
3 \\
\end{array}$ & $\begin{array}{l}64 \\
48 \\
61 \\
51 \\
38 \\
\end{array}$ & $\begin{array}{l}37 \\
22 \\
40 \\
25 \\
13 \\
\end{array}$ & $\begin{array}{r}57 \\
107 \\
56 \\
15 \\
33 \\
\end{array}$ & $\begin{array}{l}8 \\
8 \\
0 \\
2\end{array}$ & $\begin{array}{r}\cdots \\
27 \\
5 \\
19\end{array}$ & $\begin{array}{l}\dot{9} \\
\dot{9} \\
\end{array}$ & $\begin{array}{r}67 \\
68 \\
31 \\
112 \\
\end{array}$ & $\begin{array}{l}64 \\
50 \\
20 \\
57\end{array}$ & $\begin{array}{l}63 \\
52 \\
84 \\
\end{array}$ & $\begin{array}{l}63 \\
37 \\
35\end{array}$ & $\begin{array}{l}46 \\
50^{*} \\
87 \\
27^{*}\end{array}$ & $\begin{array}{r}7 \\
45 \\
6 \\
7 \\
35 \\
\end{array}$ & $\begin{array}{r}5 \\
20 \\
3 \\
2 \\
17\end{array}$ \\
\hline $\begin{array}{l}21 \\
22 \\
23 \\
24 \\
25\end{array}$ & $\begin{array}{l}\text { Yémen } \\
\text { Sénégal } \\
\text { Bangladesh } \\
\text { Madagascar } \\
\text { Soudan } \\
\end{array}$ & $\begin{array}{l}14 \\
18 \\
36 \\
56 \\
28\end{array}$ & $\begin{array}{r}3 \\
5 \\
12 \\
43 \\
6\end{array}$ & $\begin{array}{l}47^{y} \\
52 \\
47 \\
88 \\
43 \\
\end{array}$ & $\begin{array}{l}21 y \\
25 \\
22 \\
73 \\
12 \\
\end{array}$ & $\begin{array}{r}44 \\
111 \\
41 \\
196 \\
233 \\
\end{array}$ & $\begin{array}{r}12 \\
34 \\
4 \\
6 \\
53\end{array}$ & $\begin{array}{l}36 \\
66 \\
58 \\
35 \\
\end{array}$ & $\begin{array}{l}\cdots \\
26 \\
45 \\
14\end{array}$ & $\begin{array}{c}132 \\
70 \\
76 \\
99 \\
58^{x} \\
\end{array}$ & $\begin{array}{l}39 \\
49 \\
64 \\
95 \\
4+x\end{array}$ & $\begin{array}{l}59 \\
67 \\
67 \\
23^{x}\end{array}$ & $\begin{array}{l}41 \\
44 \\
65 \\
17^{x}\end{array}$ & $\begin{array}{l}31^{y} \\
85 \\
20 \\
48^{*} \\
76 \\
\end{array}$ & $\begin{array}{l}42 \\
19 \\
24 \\
23 \\
23\end{array}$ & $\begin{array}{r}7 \\
1 \mathrm{C} \\
11 \\
1 \mathrm{1} \\
17\end{array}$ \\
\hline $\begin{array}{l}26 \\
27 \\
28 \\
29 \\
30\end{array}$ & $\begin{array}{l}\text { Tanzanie, Rép.-Unie de } \\
\text { Rép. centrafricaine } \\
\text { Namibie } \\
\text { Nigéria } \\
\text { Gabon }\end{array}$ & $\begin{array}{l}48 \\
26 \\
35 \\
43\end{array}$ & $\begin{array}{r}18 \\
6 \\
14 \\
22\end{array}$ & $\begin{array}{l}93^{y} \\
52 \\
62 \\
74\end{array}$ & $\begin{array}{l}88^{y} \\
25 \\
40 \\
49\end{array}$ & $\begin{array}{r}20 \\
62 \\
125 \\
164 \\
135\end{array}$ & $\begin{array}{r}1 \\
3 \\
11 \\
6 \\
23\end{array}$ & $\begin{array}{l}33 \\
53 \\
46 \\
.\end{array}$ & $\begin{array}{l}18 \\
12 \\
27 \\
\cdots\end{array}$ & $\begin{array}{l}67 \\
83 \\
68 \\
.\end{array}$ & $\begin{array}{l}66 \\
51 \\
63 \\
. \quad .\end{array}$ & $\begin{array}{l}50 \\
59 \\
. \\
. \\
.\end{array}$ & $\begin{array}{l}51 \\
39 \\
. \\
. \\
.\end{array}$ & $\begin{array}{l}71 \\
56 \\
63^{*} \\
44\end{array}$ & $\begin{array}{l}5 \\
17 \\
28 \\
.\end{array}$ & $\begin{array}{l}E \\
\epsilon \\
1 \varepsilon\end{array}$ \\
\hline $\begin{array}{l}31 \\
32 \\
33 \\
34 \\
35\end{array}$ & $\begin{array}{l}\text { Ouganda } \\
\text { Bolivie } \\
\text { Pakistan } \\
\text { Rép.dém.pop.lao } \\
\text { Cameroun } \\
\end{array}$ & $\begin{array}{l}52 \\
68 \\
30 \\
37 \\
47\end{array}$ & $\begin{array}{l}30 \\
46 \\
11 \\
28 \\
19\end{array}$ & $\begin{array}{l}62 \\
85 \\
47 \\
66\end{array}$ & $\begin{array}{l}35 \\
71 \\
21 \\
43\end{array}$ & $\begin{array}{r}99 \\
574 \\
86 \\
124 \\
126\end{array}$ & $\begin{array}{r}6 \\
77 \\
13 \\
3 \\
12\end{array}$ & $\begin{array}{l}78 \\
46 \\
34 \\
87\end{array}$ & $\begin{array}{l}32 \\
50 \\
13 \\
16 \\
43\end{array}$ & $\begin{array}{r}76 \\
97 \\
51 \\
122 \\
119\end{array}$ & $\begin{array}{r}63 \\
85 \\
28 \\
98 \\
102 \\
\end{array}$ & $\begin{array}{l}43 \\
88 \\
. \\
. \\
85\end{array}$ & $\begin{array}{l}38 \\
78 \\
\cdot . \\
74 \\
\end{array}$ & $\begin{array}{l}76 \\
60 \\
49 y \\
38^{*} \\
70\end{array}$ & $\begin{array}{l}16 \\
40 \\
26 \\
23 \\
32\end{array}$ & $\begin{array}{l}\xi \\
3 f \\
1 \\
2 \\
2\end{array}$ \\
\hline \multirow[t]{2}{*}{$\begin{array}{l}36 \\
37 \\
38\end{array}$} & $\begin{array}{l}\text { Bénin } \\
\text { Togo } \\
\text { Inde }\end{array}$ & $\begin{array}{l}23 \\
27 \\
47\end{array}$ & $\begin{array}{r}8 \\
7 \\
20\end{array}$ & $\begin{array}{l}32 \\
56 \\
62\end{array}$ & $\begin{array}{l}16 \\
31 \\
34\end{array}$ & $\begin{array}{r}76 \\
179 \\
78\end{array}$ & $\begin{array}{l}4 \\
6 \\
7 x\end{array}$ & $\begin{array}{l}38 \\
63 \\
80\end{array}$ & $\begin{array}{l}15 \\
24 \\
40\end{array}$ & $\begin{array}{r}83 \\
124 \\
114\end{array}$ & $\begin{array}{l}43 \\
78 \\
83\end{array}$ & $\begin{array}{l}66 \\
87 \\
.\end{array}$ & $\begin{array}{l}34 \\
59 \\
.\end{array}$ & $\begin{array}{l}36 \\
52 \\
40^{*}\end{array}$ & $\begin{array}{l}23 \\
36 \\
50\end{array}$ & $\begin{array}{r}\vdots \\
1 ! \\
2 !\end{array}$ \\
\hline & $\begin{array}{l}\text { Pays a TMM5 élevé } \\
(71-140) \\
\text { Mediane }\end{array}$ & 55 & 37 & 76 & 60 & 164 & 55 & 68 & 52 & 100 & 92 & 84 & 80 & 67 & 35 & 3 \\
\hline $\begin{array}{l}39 \\
40 \\
41 \\
42 \\
43\end{array}$ & $\begin{array}{l}\text { Ghana } \\
\text { Côle d'Ivoire } \\
\text { Haïti } \\
\text { Zaïre } \\
\text { Lesotho }\end{array}$ & $\begin{array}{l}43 \\
26 \\
26^{x} \\
61 \\
49\end{array}$ & $\begin{array}{l}18 \\
10 \\
17^{x} \\
22 \\
74\end{array}$ & $\begin{array}{l}70 \\
67 \\
59 \\
84 \\
.\end{array}$ & $\begin{array}{l}51 \\
40 \\
47 \\
61 \\
.\end{array}$ & $\begin{array}{r}294 \\
128 \\
40 \\
99 \\
68\end{array}$ & $\begin{array}{r}13 \\
54 \\
4 \\
1 \\
1\end{array}$ & $\begin{array}{l}52 \\
68 \\
50 \\
88 \\
63\end{array}$ & $\begin{array}{r}25 \\
24 \\
42 \\
32 \\
102\end{array}$ & $\begin{array}{r}81 \\
82 \\
86 \\
86 \\
101\end{array}$ & $\begin{array}{r}66 \\
58 \\
80 \\
65 \\
123\end{array}$ & $\begin{array}{l}. \\
44 \\
.\end{array}$ & $\begin{array}{l}\cdots \\
42 \\
. \\
.\end{array}$ & $\begin{array}{l}73 \\
32 \\
60 \\
52\end{array}$ & $\begin{array}{l}49 \\
26 \\
20 \\
32 \\
20\end{array}$ & $\begin{array}{l}31 \\
1: \\
1 \\
1 \\
3\end{array}$ \\
\hline $\begin{array}{l}44 \\
45 \\
46 \\
47 \\
48\end{array}$ & $\begin{array}{l}\text { Zambie } \\
\text { Pérou } \\
\text { Jamahiriya arabe libyenne } \\
\text { Maroc } \\
\text { Congo }\end{array}$ & $\begin{array}{l}66 \\
81 \\
60 \\
34 \\
50\end{array}$ & $\begin{array}{l}37 \\
60 \\
13 \\
10 \\
19 \\
\end{array}$ & $\begin{array}{l}81 \\
92 \\
75 \\
61 \\
70\end{array}$ & $\begin{array}{l}65 \\
79 \\
50 \\
38 \\
44\end{array}$ & $\begin{array}{r}74 \\
241 \\
223 \\
207 \\
122\end{array}$ & $\begin{array}{l}15 \\
85 \\
70 \\
55^{x} \\
3\end{array}$ & $\begin{array}{r}51 \\
95 \\
92 \\
67 \\
103\end{array}$ & $\begin{array}{l}34 \\
71 \\
24 \\
27 \\
53\end{array}$ & $\begin{array}{r}102 \\
125 \\
80 \\
.\end{array}$ & $\begin{array}{r}92 \\
120 \\
53 \\
.\end{array}$ & $\begin{array}{l}\cdots \\
65 \\
\cdots\end{array}$ & $\begin{array}{l}\cdots \\
\dot{\cdots} \\
\dot{\cdots} \\
\dot{ }\end{array}$ & $\begin{array}{l}80 \\
70 \\
82 \\
67 \\
71\end{array}$ & $\begin{array}{l}68 \\
43 \\
37^{*}\end{array}$ & $\begin{array}{l}6 \\
3 \\
1\end{array}$ \\
\hline $\begin{array}{l}49 \\
50 \\
51 \\
52 \\
53\end{array}$ & $\begin{array}{l}\text { Kenya } \\
\text { Algérie } \\
\text { Indonésie } \\
\text { Guatemala } \\
\text { Arabie saoudite }\end{array}$ & $\begin{array}{l}44 \\
39 \\
66 \\
51 \\
15\end{array}$ & $\begin{array}{r}19 \\
11 \\
42 \\
37 \\
2\end{array}$ & $\begin{array}{l}80 \\
70 \\
84 \\
63 \\
73\end{array}$ & $\begin{array}{l}59 \\
46 \\
62 \\
47 \\
48\end{array}$ & $\begin{array}{r}91 \\
229 \\
146 \\
63 \\
280\end{array}$ & $\begin{array}{r}6 \\
71 \\
41 \\
37 \\
269\end{array}$ & $\begin{array}{l}64 \\
55 \\
86 \\
50 \\
22\end{array}$ & $\begin{array}{l}30 \\
37 \\
58 \\
39 \\
.\end{array}$ & $\begin{array}{r}95 \\
105 \\
121 \\
82 \\
78\end{array}$ & $\begin{array}{r}91 \\
87 \\
117 \\
70 \\
65\end{array}$ & $\begin{array}{r}97 \\
100 \\
64\end{array}$ & $\begin{array}{l}81 \\
97 \\
48\end{array}$ & $\begin{array}{l}51 \\
90 \\
80 \\
36 \\
90\end{array}$ & $\begin{array}{l}27 \\
61 \\
53 \\
21 \\
52\end{array}$ & $\begin{array}{l}1 \\
5 \\
4 \\
1 \\
3\end{array}$ \\
\hline $\begin{array}{l}54 \\
55 \\
56 \\
57 \\
58\end{array}$ & $\begin{array}{l}\text { Afrique du Sud } \\
\text { Myanmar } \\
\text { El Salvador } \\
\text { Zimbabwe } \\
\text { Iraq }\end{array}$ & $\begin{array}{l}85 \\
61 \\
63 \\
50\end{array}$ & $\begin{array}{l}57 \\
53 \\
47 \\
18\end{array}$ & $\begin{array}{l}89 \\
76 \\
74 \\
70\end{array}$ & $\begin{array}{l}72 \\
70 \\
60 \\
49\end{array}$ & $\begin{array}{r}323 \\
79 \\
402 \\
85 \\
200\end{array}$ & $\begin{array}{r}98 \\
2 \\
84 \\
22 \\
68\end{array}$ & $\begin{array}{l}94 \\
61 \\
. \\
94\end{array}$ & $\begin{array}{l}85 \\
52 \\
\cdots \\
36\end{array}$ & $\begin{array}{r}106 \\
79 \\
130 \\
104\end{array}$ & $\begin{array}{r}100 \\
81 \\
126 \\
87\end{array}$ & $\begin{array}{r}71 \\
100 \\
90\end{array}$ & $\begin{array}{r}\cdot \\
62 \\
100 \\
82\end{array}$ & $\begin{array}{l}33^{*} \\
31 \\
74 \\
73\end{array}$ & $\begin{array}{l}25 \\
27 \\
49 \\
60\end{array}$ & $\begin{array}{l}2 \\
3 \\
4 \\
5\end{array}$ \\
\hline $\begin{array}{l}59 \\
60 \\
61 \\
62 \\
63\end{array}$ & $\begin{array}{l}\text { Egypte } \\
\text { Botswana } \\
\text { Turquie } \\
\text { Mongolie } \\
\text { Honduras }\end{array}$ & $\begin{array}{l}50 \\
37 \\
69 \\
87 \\
55\end{array}$ & $\begin{array}{l}20 \\
44 \\
34 \\
74 \\
50\end{array}$ & $\begin{array}{l}63 \\
84 \\
90 \\
76\end{array}$ & $\begin{array}{l}34 \\
65 \\
71 \\
71\end{array}$ & $\begin{array}{l}312 \\
134 \\
161 \\
130 \\
383\end{array}$ & $\begin{array}{r}84 \\
7 \\
172 \\
32 \\
68\end{array}$ & $\begin{array}{l}80 \\
35 \\
90 \\
79 \\
68\end{array}$ & $\begin{array}{l}52 \\
48 \\
58 \\
78 \\
67\end{array}$ & $\begin{array}{l}100 \\
114 \\
121 \\
100 \\
104\end{array}$ & $\begin{array}{r}79 \\
120 \\
113 \\
103 \\
108\end{array}$ & $\begin{array}{l}94 \\
\cdot \\
8 \\
89\end{array}$ & $\begin{array}{c}100 \\
. \\
9 \\
9\end{array}$ & $\begin{array}{l}95 \\
89 \\
97 \\
43\end{array}$ & $\begin{array}{l}79 \\
31 \\
57 \\
88 \\
28\end{array}$ & $\begin{array}{l}5 \\
5 \\
\vdots \\
5 \\
\vdots\end{array}$ \\
\hline
\end{tabular}


TABLE 5: DEMOGRAPHIC INDICATORS

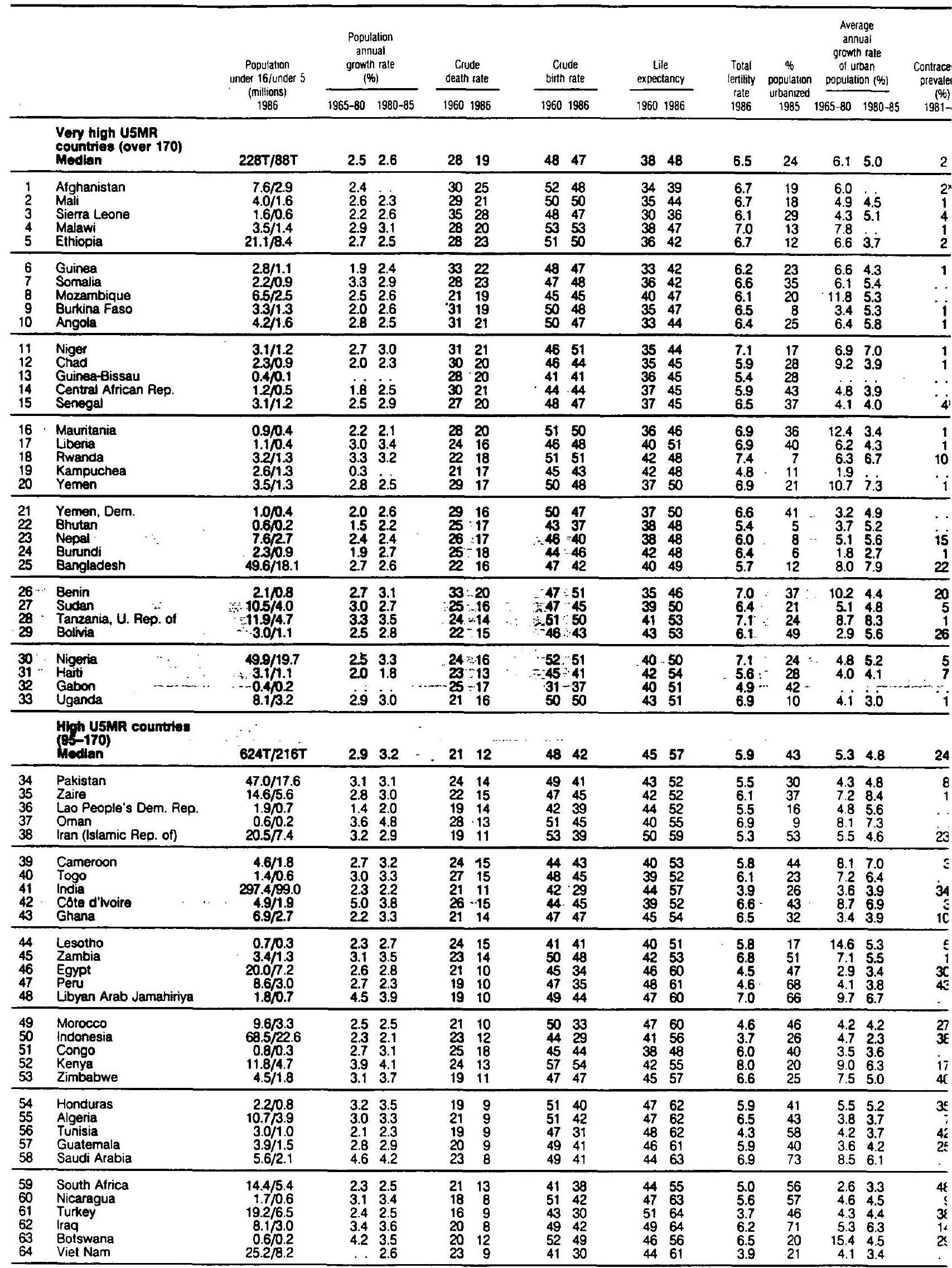

Note: nations are listed in descending order of their 1986 under-five mortality rates (see table 1) 
TABLEAU 5: INDICATEURS DÉMOGRAPHIQUES

\begin{tabular}{|c|c|c|c|c|c|c|c|c|c|c|c|c|c|c|c|}
\hline & & \multicolumn{2}{|c|}{$\begin{array}{l}\text { Population } \\
\text { (millions) } \\
1990\end{array}$} & \multicolumn{2}{|c|}{$\begin{array}{c}\text { Taux annuel } \\
\text { d'accroissement } \\
\text { de la population } \\
\text { (\%) }\end{array}$} & \multicolumn{2}{|c|}{$\begin{array}{c}\text { Taux brut } \\
\text { de mortalité }\end{array}$} & \multicolumn{2}{|c|}{$\begin{array}{l}\text { Taux brut } \\
\text { de natalité }\end{array}$} & \multicolumn{2}{|c|}{ Espèrance de vie } & \multirow{2}{*}{$\begin{array}{c}\text { Indice } \\
\text { synthétique } \\
\text { de fécanditié } \\
\text { igno }\end{array}$} & \multirow{2}{*}{$\begin{array}{l}\text { Pourcentage } \\
\text { de la } \\
\text { population } \\
\text { urbaine } \\
1990 \\
\end{array}$} & \multicolumn{2}{|c|}{$\begin{array}{c}\text { Taux annue } \\
\text { moyen } \\
\text { d"zccroisseme } \\
\text { de la paputati } \\
\text { urfaine } \\
\text { (\%) }\end{array}$} \\
\hline & & $\begin{array}{c}\text { moins de } \\
16 \text { ans } \\
\end{array}$ & $\begin{array}{c}\text { moins de } \\
5 \text { ans } \\
\end{array}$ & $19 \overline{65-1980}$ & 1980.1990 & 1960 & 1990 & 1960 & 1990 & 1960 & 1990 & & & 1965-1980 & $\overline{198 C}$ \\
\hline & $\begin{array}{l}\text { Pare a TMM5 trés dlevo } \\
\text { (supdrieur \& 140) } \\
\text { Modiene }\end{array}$ & $655 T$ & $241 \mathrm{~T}$ & 2.5 & 2.8 & 26 & 16 & 48 & 47 & 39 & 50 & 6.6 & 27 & 5.4 & 5. \\
\hline $\begin{array}{l}1 \\
2 \\
3 \\
4 \\
5\end{array}$ & $\begin{array}{l}\text { Mozambique } \\
\text { Afghanistan } \\
\text { Angola } \\
\text { Mali } \\
\text { Sierra Leone }\end{array}$ & $\begin{array}{l}7.2 \\
7.3 \\
4.7 \\
4.5 \\
1.9\end{array}$ & $\begin{array}{l}2.8 \\
3.0 \\
1.8 \\
1.8 \\
0.8\end{array}$ & $\begin{array}{l}2.5 \\
2.4 \\
2.8 \\
2.1 \\
2.0\end{array}$ & $\begin{array}{l}2.6 \\
0.3 \\
2.6 \\
2.9 \\
2.4\end{array}$ & $\begin{array}{l}26 \\
30 \\
31 \\
29 \\
33 \\
\end{array}$ & $\begin{array}{l}18 \\
23 \\
19 \\
20 \\
23\end{array}$ & $\begin{array}{l}47 \\
52 \\
50 \\
52 \\
48\end{array}$ & $\begin{array}{l}45 \\
51 \\
47 \\
51 \\
48\end{array}$ & $\begin{array}{l}37 \\
33 \\
33 \\
35 \\
32\end{array}$ & $\begin{array}{l}48 \\
43 \\
46 \\
45 \\
42\end{array}$ & $\begin{array}{l}6.3 \\
6.9 \\
6.4 \\
7.1 \\
6.5\end{array}$ & $\begin{array}{l}27 \\
18 \\
28 \\
19 \\
32\end{array}$ & \begin{tabular}{r|}
11.8 \\
6.0 \\
6.4 \\
4.9 \\
4.3
\end{tabular} & $\begin{array}{l}9 . \\
1 . \\
5 . \\
4 . \\
5\end{array}$ \\
\hline $\begin{array}{r}6 \\
7 \\
8 \\
9 \\
10 \\
\end{array}$ & $\begin{array}{l}\text { Malawi } \\
\text { Guinee-Bissau } \\
\text { Guinée } \\
\text { Burkina faso } \\
\text { Niger }\end{array}$ & $\begin{array}{l}4.4 \\
0.4 \\
2.8 \\
4.2 \\
3.9\end{array}$ & $\begin{array}{l}1.8 \\
0.2 \\
1.1 \\
1.6 \\
1.5\end{array}$ & $\begin{array}{l}2.9 \\
1.2 \\
1.9 \\
2.0 \\
2.7\end{array}$ & $\begin{array}{l}3.5 \\
1.9 \\
2.5 \\
2.6 \\
3.2\end{array}$ & $\begin{array}{l}28 \\
29 \\
31 \\
28 \\
29 \\
\end{array}$ & $\begin{array}{l}20 \\
22 \\
21 \\
18 \\
20 \\
\end{array}$ & $\begin{array}{l}54 \\
40 \\
53 \\
52 \\
53 \\
\end{array}$ & $\begin{array}{l}56 \\
43 \\
51 \\
47 \\
52\end{array}$ & $\begin{array}{l}38 \\
34 \\
34 \\
36 \\
35 \\
\end{array}$ & $\begin{array}{l}48 \\
43 \\
44 \\
48 \\
46\end{array}$ & $\begin{array}{l}7.6 \\
5.8 \\
7.0 \\
6.5 \\
7.1\end{array}$ & $\begin{array}{r}12 \\
20 \\
26 \\
9 \\
19\end{array}$ & $\begin{array}{l}7.8 \\
1.7 \\
6.6 \\
3.4 \\
6.9\end{array}$ & $\begin{array}{l}6 . \\
3 \\
5 . \\
5 . \\
7 .\end{array}$ \\
\hline $\begin{array}{l}11 \\
12 \\
13 \\
14 \\
15\end{array}$ & $\begin{array}{l}\text { Ethiopie } \\
\text { Tchad } \\
\text { Somalie } \\
\text { Mauritanie } \\
\text { Libéria }\end{array}$ & \begin{tabular}{r|}
23.5 \\
2.6 \\
3.7 \\
0.9 \\
1.2
\end{tabular} & $\begin{array}{l}9.3 \\
1.0 \\
1.4 \\
0.4 \\
0.5\end{array}$ & $\begin{array}{l}2.7 \\
2.0 \\
2.7 \\
2.3 \\
3.0\end{array}$ & $\begin{array}{l}2.4 \\
2.4 \\
3.4 \\
2.7 \\
3.2\end{array}$ & $\begin{array}{l}28 \\
30 \\
28 \\
28 \\
25\end{array}$ & $\begin{array}{l}20 \\
19 \\
19 \\
18 \\
15\end{array}$ & $\begin{array}{l}51 \\
46 \\
49 \\
48 \\
50\end{array}$ & $\begin{array}{l}49 \\
44 \\
49 \\
46 \\
47\end{array}$ & $\begin{array}{l}36 \\
35 \\
36 \\
35 \\
41\end{array}$ & $\begin{array}{l}46 \\
47 \\
46 \\
47 \\
54\end{array}$ & $\begin{array}{l}6.8 \\
5.8 \\
6.6 \\
6.5 \\
6.8\end{array}$ & $\begin{array}{l}13 \\
30 \\
36 \\
47 \\
46\end{array}$ & $\begin{array}{r}6.6 \\
9.2 \\
6.1 \\
12.4 \\
6.2 \\
\end{array}$ & $\begin{array}{l}\overline{4} \\
6 \\
5 \\
7 \\
5\end{array}$ \\
\hline $\begin{array}{l}16 \\
17 \\
18 \\
19 \\
20\end{array}$ & $\begin{array}{l}\text { Rwanda } \\
\text { Cambodge } \\
\text { Burundi } \\
\text { Bhoutan } \\
\text { Népal }\end{array}$ & $\begin{array}{l}3.7 \\
3.0 \\
2.6 \\
0.6 \\
8.5\end{array}$ & $\begin{array}{l}1.5 \\
1.4 \\
1.0 \\
0.2 \\
3.1\end{array}$ & $\begin{array}{l}3.3 \\
0.3 \\
1.9 \\
1.6 \\
2.4\end{array}$ & $\begin{array}{l}3.4 \\
2.5 \\
2.8 \\
2.0 \\
2.5\end{array}$ & $\begin{array}{l}22 \\
21 \\
23 \\
25 \\
26\end{array}$ & $\begin{array}{l}16 \\
16 \\
17 \\
16 \\
14\end{array}$ & $\begin{array}{l}50 \\
45 \\
46 \\
43 \\
46\end{array}$ & $\begin{array}{l}51 \\
39 \\
47 \\
38 \\
38\end{array}$ & $\begin{array}{l}42 \\
42 \\
41 \\
38 \\
38\end{array}$ & $\begin{array}{l}50 \\
50 \\
49 \\
49 \\
52 \\
\end{array}$ & $\begin{array}{l}8.1 \\
4.6 \\
6.8 \\
5.5 \\
5.7\end{array}$ & $\begin{array}{r}8 \\
12 \\
6 \\
5 \\
10\end{array}$ & $\begin{array}{l}6.3 \\
1.9 \\
1.8 \\
3.7 \\
5.1\end{array}$ & $\begin{array}{l}7 \\
3 \\
5 \\
5 \\
7\end{array}$ \\
\hline $\begin{array}{l}21 \\
22 \\
23 \\
24 \\
25 \\
\end{array}$ & $\begin{array}{l}\text { Yémen } \\
\text { Sénégal } \\
\text { Bangladesh } \\
\text { Madagascar } \\
\text { Soudan } \\
\end{array}$ & $\begin{array}{r}6.1 \\
3.5 \\
53.5 \\
5.7 \\
11.9 \\
\end{array}$ & $\begin{array}{r}2.4 \\
1.3 \\
19.0 \\
2.2 \\
4.5 \\
\end{array}$ & $\begin{array}{l}2.3 \\
2.5 \\
2.7 \\
2.5 \\
3.0 \\
\end{array}$ & $\begin{array}{l}3.5 \\
2.8 \\
2.7 \\
3.1 \\
3.0\end{array}$ & $\begin{array}{l}28 \\
27 \\
23 \\
24 \\
25 \\
\end{array}$ & $\begin{array}{l}15 \\
17 \\
15 \\
13 \\
15 \\
\end{array}$ & $\begin{array}{l}53 \\
50 \\
47 \\
48 \\
47 \\
\end{array}$ & $\begin{array}{l}52 \\
45 \\
41 \\
45 \\
44 \\
\end{array}$ & $\begin{array}{l}36 \\
37 \\
40 \\
41 \\
39 \\
\end{array}$ & $\begin{array}{l}51 \\
48 \\
52 \\
55 \\
51\end{array}$ & $\begin{array}{l}7.7 \\
6.3 \\
5.3 \\
6.6 \\
6.4\end{array}$ & $\begin{array}{l}29 \\
38 \\
16 \\
24 \\
22\end{array}$ & $\begin{array}{l}6.4 \\
4.1 \\
8.0 \\
5.7 \\
5.1\end{array}$ & $\begin{array}{l}7 \\
3 \\
6 \\
5 \\
4\end{array}$ \\
\hline $\begin{array}{l}26 \\
27 \\
28 \\
29 \\
30 \\
\end{array}$ & $\begin{array}{l}\text { Tanzanie, Rép.-Unie de } \\
\text { Rép. centraitricaine } \\
\text { Namibie } \\
\text { Nigéria } \\
\text { Gabon } \\
\end{array}$ & $\begin{array}{r}14.0 \\
1.4 \\
0.9 \\
53.8 \\
0.4 \\
\end{array}$ & $\begin{array}{r}5.6 \\
0.6 \\
0.3 \\
21.1 \\
0.2 \\
\end{array}$ & $\begin{array}{l}3.3 \\
1.8 \\
1.0 \\
2.5 \\
3.5 \\
\end{array}$ & $\begin{array}{l}3.7 \\
2.7 \\
3.1 \\
3.2 \\
3.7 \\
\end{array}$ & $\begin{array}{l}24 \\
26 \\
23 \\
25 \\
24 \\
\end{array}$ & $\begin{array}{l}13 \\
17 \\
11 \\
15 \\
16 \\
\end{array}$ & $\begin{array}{l}51 \\
43 \\
46 \\
52 \\
31 \\
\end{array}$ & $\begin{array}{l}50 \\
45 \\
43 \\
48 \\
41\end{array}$ & $\begin{array}{l}41 \\
39 \\
42 \\
40 \\
41\end{array}$ & $\begin{array}{l}54 \\
50 \\
58 \\
52 \\
53 \\
\end{array}$ & $\begin{array}{l}7.1 \\
6.2 \\
5.9 \\
6.8 \\
5.2 \\
\end{array}$ & $\begin{array}{l}33 \\
47 \\
28 \\
35 \\
46 \\
\end{array}$ & $\begin{array}{l}8.7 \\
4.8 \\
1.9 \\
4.8 \\
4.2 \\
\end{array}$ & $\begin{array}{r}10 \\
4 \\
5 \\
5 \\
6 \\
\end{array}$ \\
\hline $\begin{array}{l}31 \\
32 \\
33 \\
34 \\
35\end{array}$ & $\begin{array}{l}\text { Ouganda } \\
\text { Bolivie } \\
\text { Pakistan } \\
\text { Rép.dém.pop.lao } \\
\text { Cameroun }\end{array}$ & $\begin{array}{r}9.7 \\
3.4 \\
58.4 \\
1.9 \\
5.8\end{array}$ & $\begin{array}{r}3.9 \\
1.3 \\
23.0 \\
0.7 \\
2.3\end{array}$ & $\begin{array}{l}2.9 \\
2.5 \\
3.1 \\
0.6 \\
2.7\end{array}$ & $\begin{array}{l}3.6 \\
2.7 \\
3.6 \\
2.6 \\
3.1\end{array}$ & $\begin{array}{l}21 \\
22 \\
24 \\
23 \\
25\end{array}$ & $\begin{array}{l}15 \\
13 \\
12 \\
16 \\
14\end{array}$ & $\begin{array}{l}50 \\
46 \\
49 \\
45 \\
44\end{array}$ & $\begin{array}{l}52 \\
42 \\
44 \\
45 \\
47\end{array}$ & $\begin{array}{l}43 \\
43 \\
43 \\
40 \\
39\end{array}$ & $\begin{array}{l}52 \\
55 \\
58 \\
50 \\
54\end{array}$ & $\begin{array}{l}7.3 \\
5.9 \\
6.2 \\
6.7 \\
6.9\end{array}$ & $\begin{array}{l}10 \\
51 \\
32 \\
19 \\
41\end{array}$ & $\begin{array}{l}4.1 \\
2.9 \\
4.3 \\
4.8 \\
8.1\end{array}$ & $\begin{array}{l}5 \\
4 \\
4 \\
5 \\
5\end{array}$ \\
\hline $\begin{array}{l}36 \\
37 \\
38\end{array}$ & $\begin{array}{l}\text { Bénin } \\
\text { Togo } \\
\text { Inde }\end{array}$ & $\begin{array}{r}2.3 \\
1.7 \\
329.0\end{array}$ & $\begin{array}{r}0.9 \\
0.6 \\
114.4\end{array}$ & $\begin{array}{l}2.7 \\
3.0 \\
2.3\end{array}$ & $\begin{array}{r}\cdot 2.9 \\
3.0 \\
2.1\end{array}$ & $\begin{array}{l}33 \\
26 \\
21\end{array}$ & $\begin{array}{l}19 \\
13 \\
11\end{array}$ & $\begin{array}{l}47 \\
48 \\
43\end{array}$ & $\begin{array}{l}49 \\
45 \\
32\end{array}$ & $\begin{array}{l}35 \\
39 \\
44\end{array}$ & $\begin{array}{l}47 \\
54 \\
59\end{array}$ & $\begin{array}{l}7.1 \\
6.6 \\
4.2\end{array}$ & $\begin{array}{l}38 \\
26 \\
27\end{array}$ & $\begin{array}{r}10.2 \\
7.2 \\
3.6\end{array}$ & $\begin{array}{l}4 \\
\epsilon \\
\vdots\end{array}$ \\
\hline & $\begin{array}{l}\text { Poye d TMM5 eleve } \\
\text { (71-140) } \\
\text { Mediane }\end{array}$ & 3261 & $114 \mathrm{~T}$ & 2.8 & 2.8 & 20 & 9 & 49 & 38 & 46 & 62 & 5.2 & 46 & 4.7 & 4 \\
\hline $\begin{array}{l}39 \\
40 \\
41 \\
42 \\
43 \\
\end{array}$ & $\begin{array}{l}\text { Ghana } \\
\text { Côte d'Ivoire } \\
\text { Haiti } \\
\text { Zaîre } \\
\text { Lesotho } \\
\end{array}$ & $\begin{array}{r}7.1 \\
6.0 \\
2.8 \\
17.2 \\
0.8 \\
\end{array}$ & $\begin{array}{l}2.8 \\
2.4 \\
1.0 \\
6.6 \\
0.3 \\
\end{array}$ & $\begin{array}{l}2.2 \\
4.2 \\
2.0 \\
2.8 \\
2.3 \\
\end{array}$ & $\begin{array}{l}3.4 \\
3.8 \\
1.9 \\
3.0 \\
2.8 \\
\end{array}$ & $\begin{array}{l}19 \\
25 \\
24 \\
23 \\
24 \\
\end{array}$ & $\begin{array}{l}13 \\
14 \\
13 \\
14 \\
12 \\
\end{array}$ & $\begin{array}{l}48 \\
53 \\
42 \\
47 \\
43 \\
\end{array}$ & $\begin{array}{l}44 \\
50 \\
36 \\
46 \\
4 i \\
\end{array}$ & $\begin{array}{l}45 \\
39 \\
42 \\
41 \\
42 \\
\end{array}$ & $\begin{array}{l}55 \\
53 \\
56 \\
53 \\
57 \\
\end{array}$ & $\begin{array}{l}6.3 \\
7.4 \\
4.9 \\
6.1 \\
5.8 \\
\end{array}$ & $\begin{array}{l}33 \\
40 \\
28 \\
39 \\
20 \\
\end{array}$ & $\begin{array}{r}3.4 \\
8.7 \\
4.0 \\
7.2 \\
14.6 \\
\end{array}$ & 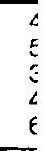 \\
\hline $\begin{array}{l}44 \\
45 \\
46 \\
47 \\
48\end{array}$ & $\begin{array}{l}\text { Zambie } \\
\text { Pérou } \\
\text { Jamahiriya arabe libyenne } \\
\text { Maroc } \\
\text { Congo }\end{array}$ & $\begin{array}{r}4.3 \\
8.6 \\
2.2 \\
10.7 \\
1.1\end{array}$ & $\begin{array}{l}1.8 \\
2.9 \\
0.8 \\
3.8 \\
0.4\end{array}$ & $\begin{array}{l}3.1 \\
2.8 \\
4.6 \\
2.5 \\
2.7\end{array}$ & $\begin{array}{l}3.9 \\
2.2 \\
4.0 \\
2.6 \\
3.1\end{array}$ & $\begin{array}{l}23 \\
19 \\
19 \\
21 \\
23\end{array}$ & $\begin{array}{r}13 \\
8 \\
9 \\
9 \\
14 \\
14\end{array}$ & $\begin{array}{l}50 \\
47 \\
49 \\
50 \\
45\end{array}$ & $\begin{array}{l}51 \\
30 \\
44 \\
34 \\
46\end{array}$ & $\begin{array}{l}42 \\
48 \\
47 \\
47 \\
42\end{array}$ & $\begin{array}{l}54 \\
63 \\
62 \\
62 \\
54\end{array}$ & $\begin{array}{l}7.2 \\
3.8 \\
6.8 \\
4.5 \\
6.3\end{array}$ & $\begin{array}{l}50 \\
70 \\
70 \\
48 \\
40\end{array}$ & $\begin{array}{l}7.1 \\
4.1 \\
9.7 \\
4.2 \\
3.5\end{array}$ & $\begin{array}{l}\xi \\
\xi \\
\xi \\
\varepsilon\end{array}$ \\
\hline $\begin{array}{l}49 \\
50 \\
51 \\
52 \\
53\end{array}$ & $\begin{array}{l}\text { Kenya } \\
\text { Algérie } \\
\text { Indonésie } \\
\text { Guatemala } \\
\text { Arabie saoudite } \\
\end{array}$ & $\begin{array}{r}12.6 \\
11.5 \\
70.0 \\
4.4 \\
6.7 \\
\end{array}$ & $\begin{array}{r}4.7 \\
3.8 \\
22.8 \\
1.6 \\
2.5\end{array}$ & $\begin{array}{l}3.6 \\
3.1 \\
2.3 \\
2.8 \\
4.6\end{array}$ & $\begin{array}{l}3.7 \\
2.9 \\
2.0 \\
2.8 \\
4.1\end{array}$ & $\begin{array}{l}23 \\
20 \\
23 \\
20 \\
23 \\
\end{array}$ & $\begin{array}{r}11 \\
8 \\
9 \\
8 \\
7 \\
\end{array}$ & $\begin{array}{l}53 \\
51 \\
44 \\
49 \\
49 \\
\end{array}$ & $\begin{array}{l}47 \\
35 \\
28 \\
40 \\
42 \\
\end{array}$ & $\begin{array}{l}45 \\
47 \\
41 \\
46 \\
44 \\
\end{array}$ & $\begin{array}{l}60 \\
65 \\
61 \\
63 \\
65 \\
\end{array}$ & $\begin{array}{l}6.9 \\
5.1 \\
3.3 \\
5.6 \\
7.1 \\
\end{array}$ & $\begin{array}{l}24 \\
52 \\
31 \\
39 \\
77 \\
\end{array}$ & $\begin{array}{l}9.0 \\
3.8 \\
4.7 \\
3.6 \\
8.5 \\
\end{array}$ & 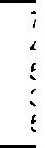 \\
\hline $\begin{array}{l}54 \\
55 \\
56 \\
57 \\
58\end{array}$ & $\begin{array}{l}\text { Afrique du Sud } \\
\text { Myanmar } \\
\text { El Salvador } \\
\text { Zimbabwe } \\
\text { Iraq }\end{array}$ & $\begin{array}{r}13.8 \\
16.4 \\
2.5 \\
4.6 \\
9.2 \\
\end{array}$ & $\begin{array}{l}4.9 \\
5.6 \\
0.8 \\
1.7 \\
3.4 \\
\end{array}$ & $\begin{array}{l}2.4 \\
2.3 \\
2.7 \\
3.1 \\
3.4\end{array}$ & $\begin{array}{l}2.2 \\
2.1 \\
1.5 \\
3.1 \\
3.5\end{array}$ & $\begin{array}{l}17 \\
21 \\
16 \\
20 \\
20 \\
\end{array}$ & $\begin{array}{r}9 \\
9 \\
8 \\
10 \\
7 \\
\end{array}$ & $\begin{array}{l}42 \\
42 \\
49 \\
53 \\
49 \\
\end{array}$ & $\begin{array}{l}31 \\
30 \\
36 \\
41 \\
42 \\
\end{array}$ & $\begin{array}{l}49 \\
44 \\
51 \\
45 \\
49 \\
\end{array}$ & $\begin{array}{l}62 \\
61 \\
64 \\
60 \\
65 \\
\end{array}$ & $\begin{array}{l}4.3 \\
3.9 \\
4.7 \\
5.6 \\
6.1 \\
\end{array}$ & $\begin{array}{l}59 \\
25 \\
44 \\
28 \\
71\end{array}$ & $\begin{array}{l}2.6 \\
2.8 \\
3.5 \\
7.5 \\
5.3 \\
\end{array}$ & $\vdots$ \\
\hline $\begin{array}{l}59 \\
60 \\
61 \\
62 \\
63\end{array}$ & $\begin{array}{l}\text { Egypte } \\
\text { Botswana } \\
\text { Turquie } \\
\text { Mongolie } \\
\text { Honduras }\end{array}$ & $\begin{array}{r}21.7 \\
0.7 \\
20.5 \\
1.0 \\
2.4\end{array}$ & $\begin{array}{l}7.6 \\
0.3 \\
7.1 \\
0.3 \\
0.9\end{array}$ & $\begin{array}{l}2.4 \\
3.5 \\
2.4 \\
3.0 \\
3.2\end{array}$ & $\begin{array}{l}2.5 \\
3.7 \\
2.3 \\
2.8 \\
3.4\end{array}$ & $\begin{array}{l}21 \\
21 \\
18 \\
18 \\
19\end{array}$ & $\begin{array}{r}10 \\
11 \\
8 \\
8 \\
8\end{array}$ & $\begin{array}{l}45 \\
52 \\
45 \\
43 \\
51\end{array}$ & $\begin{array}{l}33 \\
46 \\
28 \\
35 \\
39\end{array}$ & $\begin{array}{l}46 \\
46 \\
50 \\
47 \\
46\end{array}$ & $\begin{array}{l}60 \\
60 \\
65 \\
63 \\
65\end{array}$ & $\begin{array}{l}4.3 \\
6.7 \\
3.5 \\
4.9 \\
5.2\end{array}$ & $\begin{array}{l}47 \\
28 \\
61 \\
52 \\
44\end{array}$ & $\begin{array}{r}2.9 \\
15.4 \\
4.3 \\
4.5 \\
5.5\end{array}$ & $\vdots$ \\
\hline
\end{tabular}

Note : Les pays sont énumérés par ordre décroissant de taux de mortalité des moins de 5 ans pour 1990 (voir tableau 1) 
TABLE 6: ECONOMIC INDICATORS

\begin{tabular}{|c|c|c|c|c|c|c|c|c|c|c|}
\hline & & \multirow{2}{*}{$\begin{array}{l}\text { GNP per } \\
\text { capila } \\
\text { (US \$) } \\
1985 \\
\end{array}$} & \multicolumn{2}{|c|}{$\begin{array}{l}\text { GNP per } \\
\text { capita } \\
\text { average } \\
\text { annual } \\
\text { grown rate } \\
\text { (\%) }\end{array}$} & \multirow{2}{*}{$\begin{array}{c}\text { Rale of } \\
\text { inflation } \\
\text { (\%) } \\
1980-85 \\
\end{array}$} & \multirow{2}{*}{$\begin{array}{c}\text { \% ol } \\
\text { population } \\
\text { below absolute } \\
\text { poverty level } \\
\text { ig77-85 } \\
\text { urban/rural } \\
\end{array}$} & \multirow{2}{*}{$\begin{array}{c}\text { \%o of central } \\
\text { govit. expenditure } \\
\text { allocated to } \\
\text { healih/education/detence } \\
1985 \\
\end{array}$} & \multirow{2}{*}{$\begin{array}{l}\text { ODA inflow } \\
\text { in millions } \\
\text { US } \$(1984) \text { (1984 } \\
\text { as a \% of } \\
\text { iectpient } \\
\text { GNP (1985) }\end{array}$} & \multicolumn{2}{|c|}{$\begin{array}{l}\text { Debt service } \\
\text { as a \% of } \\
\text { exports of } \\
\text { goods and } \\
\text { services }\end{array}$} \\
\hline & & & $965-80$ & $1980-85$ & & & & & 1970 & 198 \\
\hline & $\begin{array}{l}\text { Very high U5MR } \\
\text { countries (over 170) } \\
\text { Median }\end{array}$ & 280 & 0.2 & -1.0 & 9.7 & $35 / 65$ & $5.5 / 14.0 / 13.8$ & $184 / 10.6$ & 4.2 & 16. \\
\hline $\begin{array}{l}1 \\
2 \\
3 \\
4 \\
5\end{array}$ & $\begin{array}{l}\text { Afghanistan } \\
\text { Mali } \\
\text { Sierra Leone } \\
\text { Malawi } \\
\text { Ethiopia }\end{array}$ & $\begin{array}{l}150 \\
350 \\
170 \\
110\end{array}$ & $\begin{array}{l}1.4 \\
1.1 \\
1.5 \\
0.2 \\
\end{array}$ & $\begin{array}{l}-3.0 \\
-0.2 \\
-0.6 \\
-2.0\end{array}$ & $\begin{array}{r}7.4 \\
25.0 \\
11.4 \\
2.6 \\
\end{array}$ & $\begin{array}{c}18 / 36 \\
27^{x} / 48^{x} \\
.165 \\
25 / 85 \\
60^{x} / 65^{x} \\
\end{array}$ & $\begin{array}{l}4.0 y / 17.00^{\prime} / 18.0 y \\
7.5 / 16.5 / 4.4 \\
7.9 / 12.3 / 5.7 \\
.1 .\end{array}$ & $\begin{array}{c}17 / \% \\
380 / 34.9 \\
66 / 5.5 \\
113 / 11.0 \\
710 / 15.1\end{array}$ & $\begin{array}{r}1.4 \\
10.4 \\
7.7 \\
11.4\end{array}$ & $\begin{array}{r}16 \\
5 \\
10 \\
\end{array}$ \\
\hline $\begin{array}{r}6 \\
7 \\
8 \\
9 \\
10\end{array}$ & $\begin{array}{l}\text { Guinea } \\
\text { Somalia } \\
\text { Mozambique } \\
\text { Burkina Faso } \\
\text { Angola }\end{array}$ & $\begin{array}{l}320 \\
280 \\
160 \\
150 \\
470^{x}\end{array}$ & $\begin{array}{r}0.8 \\
-0.7 \\
1.3 \\
\ldots\end{array}$ & $\begin{array}{r}-1.4 \\
0.6 \\
-13.6 \\
-1.3 \\
0.1\end{array}$ & $\begin{array}{r}8.3 \\
45.4 \\
25.8 \\
7.2 \\
.\end{array}$ & $\begin{array}{l}40 \% \overline{7} \\
\% \\
\% \\
\%\end{array}$ & $\begin{array}{l}1 / \% \\
7.0^{*} / 16.0^{*} / . \\
5.5 / 16.9 / 18.2 \\
\ldots / .\end{array}$ & $\begin{array}{c}119 / 6.5 \\
354 / 14.5 \\
300 / 9.2 \\
197 / 18.4 \\
92 \% .\end{array}$ & $\begin{array}{l}2 . i \\
6.8\end{array}$ & 44 \\
\hline $\begin{array}{l}11 \\
12 \\
13 \\
14 \\
15\end{array}$ & $\begin{array}{l}\text { Niger } \\
\text { Chad } \\
\text { Guinea-Bissau } \\
\text { Central African Rep. } \\
\text { Senegal }\end{array}$ & $\begin{array}{l}250 \\
80^{x} \\
180 \\
260 \\
370\end{array}$ & $\begin{array}{l}-2.1 \\
-2.3 \\
-1.5 \\
-0.2 \\
-0.6\end{array}$ & $\begin{array}{r}-6.7 \\
1.8 \\
1.9 \\
-1.5 \\
0.0\end{array}$ & $\begin{array}{r}8.5 \\
30.4 \\
10.8 \\
9.7 \\
\end{array}$ & $\begin{array}{c}30^{x} / 55^{x} \\
.191 \\
.191 \\
.1\end{array}$ & $\begin{array}{l}\cdots / \% \\
\cdots / 140 \% \\
\cdots / \%\end{array}$ & $\begin{array}{l}305 / 19.8 \\
182 \% \\
105 / 15.9 \\
295 / 12.2\end{array}$ & $\begin{array}{l}4.0 \\
4.2 \\
5 . i \\
2.9\end{array}$ & $\begin{array}{r}11 \\
9\end{array}$ \\
\hline \multirow{2}{*}{$\begin{array}{l}16 \\
17 \\
18 \\
19 \\
20 \\
\end{array}$} & \multirow{2}{*}{$\begin{array}{l}\text { Mauritania } \\
\text { Liberia } \\
\text { Rwanda } \\
\text { Kampuchea } \\
\text { Yemen } \\
\end{array}$} & $\begin{array}{l}420 \\
470 \\
280\end{array}$ & $\begin{array}{r}0.1 \\
-1.4 \\
1.8\end{array}$ & $\begin{array}{l}-0.7 \\
-6.4 \\
-1.5\end{array}$ & $\begin{array}{l}8.1 \\
1.6 \\
7.6\end{array}$ & $30 / 90^{x}$ & $\begin{array}{l}5.5 / 16.5 / 9.5 \\
\cdots / 1\end{array}$ & $\begin{array}{c}205 / 31.2 \\
91 / 8.8 \\
181 / 10.7\end{array}$ & $\begin{array}{l}3.3 \\
1.2\end{array}$ & $\begin{array}{r}19 \\
3 \\
4\end{array}$ \\
\hline & & 550 & 5.3 & 0.9 & 9.7 & $\%$ & $4.4 / 20.6 / 30.1$ & $288 / 7.0$ & $\cdots$ & 55 \\
\hline $\begin{array}{l}21 \\
22 \\
23 \\
24 \\
25 \\
\end{array}$ & $\begin{array}{l}\text { Yemen, Dem. } \\
\text { Bhutan } \\
\text { Nepad } \\
\text { Burundi } \\
\text { Bangladesh } \\
\end{array}$ & $\begin{array}{l}530 \\
160 \\
160 \\
230 \\
150 \\
\end{array}$ & $\begin{array}{l}0.1 \\
1.9 \\
0.4 \\
\end{array}$ & $\begin{array}{r}3.4^{x} \\
0.8 \\
-0.8 \\
0.9 \\
\end{array}$ & $\begin{array}{r}5.7 \\
8.4 \\
6.6 \\
11.5 \\
\end{array}$ & $\begin{array}{l}. / 20 \\
55 / 61 \\
55 / 85 \\
86 / 86 \\
\end{array}$ & $\begin{array}{l}\ldots 1 \\
5.0 / 12.1 / 6.2 \\
2.0 \% 4.0 \%\end{array}$ & $\begin{array}{r}112 / 10.4 \\
24 / 12.9 \\
236 / 10.1 \\
143 / 13.7 \\
1142 / 7.1 \\
\end{array}$ & $\begin{array}{l}0.0 \\
\cdots \\
2.3 \\
\cdots\end{array}$ & $\begin{array}{r}42 \\
4 \\
16 \\
16 \\
\end{array}$ \\
\hline $\begin{array}{l}26 \\
27 \\
28 \\
29 \\
\end{array}$ & $\begin{array}{l}\text { Benin } \\
\text { Sudan } \\
\text { Janzania, U. Rep. of } \\
\text { Bolivia }\end{array}$ & $\begin{array}{l}260 \\
300 \\
290 \\
470 \\
\end{array}$ & $\begin{array}{r}0.2 \\
(.) \\
-0.2 \\
\end{array}$ & $\begin{array}{r}0.1 \\
-4.2 \\
-3.1 \\
-7.0 \\
\end{array}$ & $\begin{array}{r}9.7 \\
31.7 \\
19.6 \\
569.1 \\
\end{array}$ & $\begin{array}{r}. / 65 \\
. / 85^{x} \\
155^{\circ} / 25^{*} \\
. . / 85^{x} \\
\end{array}$ & $\begin{array}{l}6.1 / . / 33.6 \\
4.9 / 7.2 / 13.8 \\
1.5 / 12.2 / 5.4\end{array}$ & $\begin{array}{c}96 / 9.5 \\
1129 / 15.6 \\
487 / 7.9 \\
202 / 6.2 \\
\end{array}$ & $\begin{array}{r}2.3 \\
10.7 \\
5.2 \\
11.3 \\
\end{array}$ & $\begin{array}{l}15 \\
16 \\
29 \\
\end{array}$ \\
\hline \multirow[t]{2}{*}{$\begin{array}{l}30 \\
31 \\
32 \\
33 \\
\end{array}$} & $\begin{array}{l}\text { Nigeria } \\
\text { Haiti } \\
\text { Gabon } \\
\text { Uganda } \\
\end{array}$ & $\begin{array}{r}800 \\
310 \\
3670 \\
230 \\
\end{array}$ & $\begin{array}{r}2.2 \\
0.7 \\
1.5 \\
-2.6 \\
\end{array}$ & $\begin{array}{r}-7.3 \\
-2.5 \\
-1.2 \\
2.2 \\
\end{array}$ & $\begin{array}{r}11.4 \\
7.0 \\
10.1\end{array}$ & $\begin{array}{l}55 \% 8 \\
\% \% \\
\end{array}$ & $\begin{array}{l}3.0 / 5.0 / 12.0 \\
5.7 / 6.0 / 8.4 \\
2.5 / 11.7 / 16.7 \\
\end{array}$ & $\begin{array}{l}32 / .) \\
153 / 8.0 \\
184 \% \\
\end{array}$ & $\begin{array}{l}4.2 \\
7.7 \\
2.9 \\
\end{array}$ & $\begin{array}{r}30 \\
5\end{array}$ \\
\hline & $\begin{array}{l}\text { High U5MR countries } \\
\text { (95-170) } \\
\text { Median }\end{array}$ & 770 & 2.2 & 0.1 . & 10.4 & $30 / 45$ & $4.5 / 14.0 / 12.4$ & $161 / 3.5$ & 7.2 & 19 \\
\hline $\begin{array}{l}34 \\
35 \\
36 \\
37 \\
38 \\
\end{array}$ & $\begin{array}{l}\text { Pakistan } \\
\text { Zaire } \\
\text { Lao People's Dem. Rep. } \\
\text { Oman } \\
\text { Iran (Islamic Rep. of) } \\
\end{array}$ & $\begin{array}{r}380 \\
170 \\
6730\end{array}$ & $\begin{array}{r}2.6 \\
-2.1 \\
5.7\end{array}$ & $\begin{array}{r}2.8 \\
-3.8 \\
0.5 \\
7.1^{\times} \\
\end{array}$ & $\begin{array}{r}8.1 \\
55.3 \\
57.0 \\
4.9 \\
\quad . \\
\end{array}$ & $\begin{array}{l}32 / 29 \\
. / 80^{x} \\
1 / . \\
1 / \\
.1 \\
\end{array}$ & $\begin{array}{l}1.1 / 2.9 / 32.3 \\
1.8 / 0.8 / 5.2 \\
1 / 9.0 \% / / 4 \\
4.2 / 7.7 / 43.0 \\
7.4 / 16.2 / 10.2 \\
\end{array}$ & $\begin{array}{c}750 / 2.2 \\
324 / 7.5 \\
37 / 2.7 \\
78 / 1.0 \\
17 / \\
\end{array}$ & $\begin{array}{r}23.4 \\
4.4\end{array}$ & 28 \\
\hline $\begin{array}{l}39 \\
40 \\
41 \\
42 \\
43\end{array}$ & $\begin{array}{l}\text { Cameroon } \\
\text { Togo } \\
\text { India } \\
\text { Cóte d'lvoire } \\
\text { Ghana }\end{array}$ & $\begin{array}{l}810 \\
230 \\
270 \\
660 \\
380\end{array}$ & $\begin{array}{r}3.6 \\
0.3 \\
1.7 \\
0.9 \\
-2.2 \\
\end{array}$ & $\begin{array}{r}4.5 \\
-5.6 \\
3.1 \\
-5.2 \\
-3.9 \\
\end{array}$ & $\begin{array}{r}11.8 \\
6.9 \\
7.8 \\
10.0 \\
57.0 \\
\end{array}$ & $\begin{array}{l}15 / 40 \\
42 / .1 \% \\
40 / 51 \\
30^{\circ} / 26 \\
59^{*} / 37^{*}\end{array}$ & $\begin{array}{l}5.1 / 14.4 / 8.8 \\
3.6 / 11.7 / 6.9 \\
2.4 / 1.9 / 18.8 \\
9.8 / 18.0 / 7.5\end{array}$ & $\begin{array}{c}160 / 2.1 \\
114 / 17.5 \\
1470 / 0.7 \\
125 / 1.9 \\
204 / 4.1 \\
\end{array}$ & $\begin{array}{r}3.2 \\
3.0 \\
23.7 \\
7.0 \\
5.2 \\
\end{array}$ & $\begin{array}{r}10 \\
27 \\
5 \\
17 \\
12\end{array}$ \\
\hline $\begin{array}{l}44 \\
45 \\
46 \\
47 \\
48\end{array}$ & $\begin{array}{l}\text { Lesotho } \\
\text { Zambia } \\
\text { Egypt } \\
\text { Peru } \\
\text { Libyan Arab Jamahiriya }\end{array}$ & $\begin{array}{r}470 \\
390 \\
610 \\
1010 \\
7170 \\
\end{array}$ & $\begin{array}{r}6.5 \\
-1.6 \\
3.1 \\
0.2 \\
-1.3 \\
\end{array}$ & $\begin{array}{r}3.4 \\
-4.1 \\
1.3 \\
-4.2 \\
-9.1 \\
\end{array}$ & $\begin{array}{r}11.4 \\
14.7 \\
11.0 \\
98.6 \\
-0.3 \\
\end{array}$ & $\begin{array}{l}50 / 55 \\
25 \% \\
21^{\prime} \times 25^{x} \\
49 \% \\
.1 \% \\
\end{array}$ & $\begin{array}{l}5.8 / 14.8 / 11.8 \\
2.4 / 10.6 / 17.5 \\
. / .\end{array}$ & $\begin{array}{c}94 / 16.5 \\
329 / 15.4 \\
1759 / 6.1 \\
316 / 2.0 \\
5 /(.) \\
\end{array}$ & $\begin{array}{r}6.3 \\
36.8 \\
11.6\end{array}$ & $\begin{array}{r}6 \\
10 \\
30 \\
7\end{array}$ \\
\hline $\begin{array}{l}49 \\
50 \\
51 \\
52 \\
53 \\
\end{array}$ & $\begin{array}{l}\text { Morocco } \\
\text { Indonesia } \\
\text { Congo } \\
\text { Kenya } \\
\text { Zimbabwe } \\
\end{array}$ & $\begin{array}{r}560 \\
530 \\
1110 \\
290 \\
680 \\
\end{array}$ & $\begin{array}{l}2.2 \\
4.8 \\
3.8 \\
1.9 \\
1.6 \\
\end{array}$ & $\begin{array}{r}0.1 \\
2.3 \\
4.9 \\
-1.7 \\
0.0 \\
\end{array}$ & $\begin{array}{r}7.8 \\
10.7 \\
12.6 \\
10.0 \\
13.2 \\
\end{array}$ & $\begin{array}{l}28 / 45 \\
26 / 44 \\
10 / 55 \\
. \% \\
\end{array}$ & $\begin{array}{l}3.1 / 19.2 / 14.9 \\
2.5 / 11.3 / 12.9 \\
6 . / 119.8 / 12.9 \\
6.2 / 20.4 / 16.2 \\
\end{array}$ & $\begin{array}{r}834 / 7.5 \\
603 / 0.7 \\
71 / 3.5 \\
439 / 7.9 \\
237 / 4.9 \\
\end{array}$ & $\begin{array}{c}8.6 \\
\cdots \\
5.8 \\
\cdots \\
\end{array}$ & $\begin{array}{l}32 \\
19 \\
19 \\
25 \\
32 \\
\end{array}$ \\
\hline $\begin{array}{l}54 \\
55 \\
56 \\
57 \\
58 \\
\end{array}$ & $\begin{array}{l}\text { Honduras } \\
\text { Algeria } \\
\text { Tunisia } \\
\text { Guatemala } \\
\text { Saudi Arabia } \\
\end{array}$ & $\begin{array}{r}720 \\
2550 \\
1190 \\
1250 \\
8850 \\
\end{array}$ & $\begin{array}{l}0.4 \\
3.6 \\
4.0 \\
1.7 \\
5.3\end{array}$ & $\begin{array}{r}-2.6 \\
1.7 \\
1.4 \\
-4.3 \\
-7.3 \\
\end{array}$ & $\begin{array}{r}5.4 \\
6.9 \\
10.0 \\
7.4 \\
-3.2 \\
\end{array}$ & $\begin{array}{l}14 / 55 \\
20 \% \\
20 / 15 \\
66 / 74 \\
. \% \\
\end{array}$ & $\begin{array}{c}\% / \% \\
6.5 / 14.3 \% / 7.9 \\
6.0 \% / 14.0 \% / 36.0 y\end{array}$ & $\begin{array}{c}276 / 8.7 \\
173 / 0.3 \\
162 / 2.1 \\
83 / 0.8 \\
29 /(.) \\
\end{array}$ & $\begin{array}{r}3.1 \\
3.9 \\
19.5 \\
7.4\end{array}$ & $\begin{array}{l}17 \\
33 \\
24 \\
21\end{array}$ \\
\hline $\begin{array}{l}59 \\
60 \\
61 \\
62 \\
63 \\
64\end{array}$ & $\begin{array}{l}\text { South Africa } \\
\text { Nicaragua } \\
\text { Turkey } \\
\text { iraq } \\
\text { Botswana } \\
\text { Viet Nam }\end{array}$ & $\begin{array}{c}2010 \\
770 \\
1080 \\
3020^{x} \\
840\end{array}$ & $\begin{array}{r}1.1 \\
-2.1 \\
2.6 \\
8.3\end{array}$ & $\begin{array}{r}-1.6 \\
-3.1 \\
2.1 \\
7.4\end{array}$ & $\begin{array}{r}13.0 \\
33.8 \\
37.1 \\
5.2\end{array}$ & $\begin{array}{l}21 / 19 \\
. / 1 / 40^{x} \\
40 / 55 \\
. / 1\end{array}$ & $\begin{array}{c}\% / \% \\
1.8 / 10.0 / 10.9 \\
4.0 * 3.0 * \% \\
4.8 / 17.5 / 6.8 \\
6.2^{*} / 7.0^{*} /\end{array}$ & $\begin{array}{c}102 / 4.0 \\
176 / 0.3 \\
26 / . \\
97 / 13.7 \\
114 \% .\end{array}$ & $\begin{array}{r}10.5 \\
22.1 \\
\cdots \\
\cdots \\
\end{array}$ & 30 \\
\hline
\end{tabular}

Note: nations are listed in descending order of their 1986 under-five mortality rates (see table 1) 
TABLEAU 6: INDICATEURS ÉCONOMIQUES

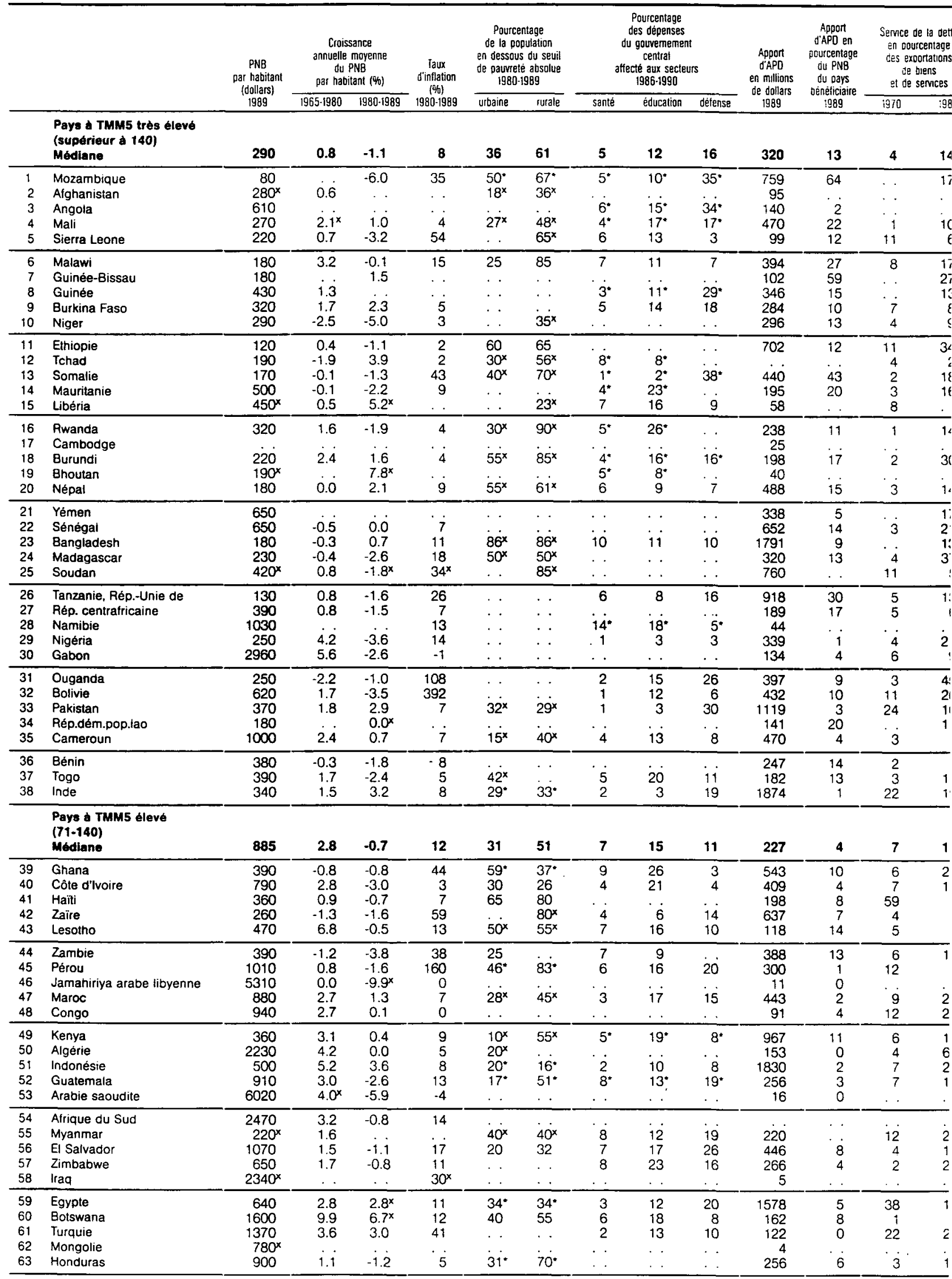




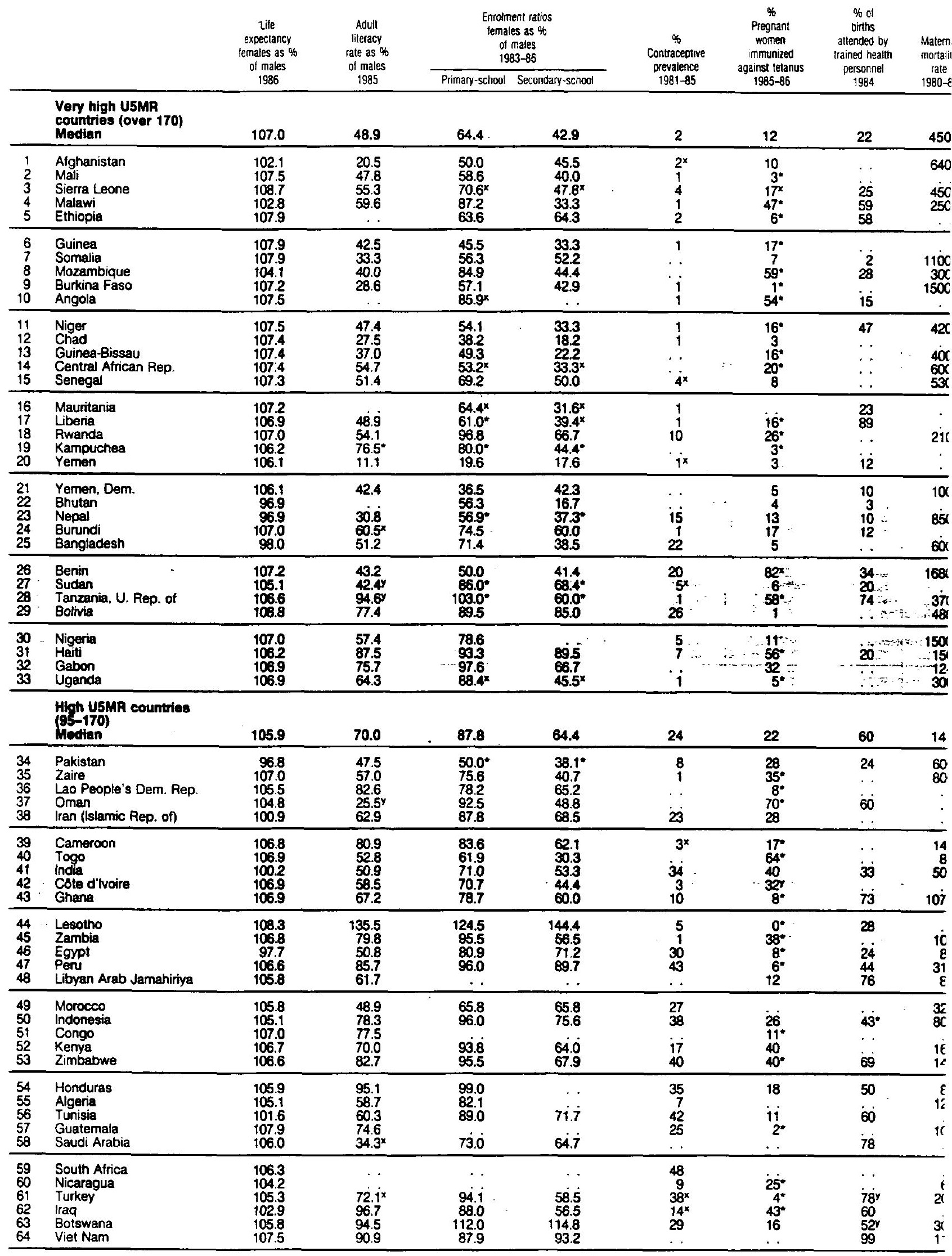

Note: nations are listed in descending order of their 1986 under-five mortality rates (see table 1) 


\begin{tabular}{|c|c|c|c|c|c|c|c|c|c|}
\hline & & \multirow{2}{*}{$\begin{array}{c}\text { Espérance de vie } \\
\text { des cemmes } \\
\text { (cormparée } \\
\text { à celle des } \\
\text { hommes. } \\
1990 \text {. } \\
190\end{array}$} & \multirow[t]{2}{*}{$\begin{array}{c}\text { Taux } \\
\text { d"alphabétisation } \\
\text { des fermmes } \\
\text { adultes } \\
\text { (comparé à celui } \\
\text { des hommes. "ैo) } \\
1990\end{array}$} & \multicolumn{2}{|c|}{$\begin{array}{l}\text { Taux d'inscription des filles à l'école } \\
\text { (Comparé à celiui des garcons. \%) } \\
1986.1989\end{array}$} & \multirow{2}{*}{$\begin{array}{l}\text { Iaux d'emploi } \\
\text { de contraceptis } \\
\text { (\$5) } \\
1980-1990\end{array}$} & \multirow{2}{*}{$\begin{array}{c}\text { Fernmes encerntes } \\
\text { vaccinées } \\
\text { contre le tétanos } \\
(\%) \text { ) } \\
1989-1990\end{array}$} & \multirow{2}{*}{$\begin{array}{c}\text { Pourcentage } \\
\text { d'accuuctements } \\
\text { assistes } \\
\text { par du personnel } \\
\text { soignant qualifiè } \\
\text { 1983-1990 }\end{array}$} & \multirow{2}{*}{$\begin{array}{l}\text { Taux } \\
\text { Je mortalite } \\
\text { Tiaternelle } \\
\text { i980-1990 }\end{array}$} \\
\hline & & & & Enseign. primaire & Enseign. secondaire & & & & \\
\hline & $\begin{array}{l}\text { Pays a TMM5 très élevé } \\
\text { (superieur 140) } \\
\text { Mediane }\end{array}$ & 106.3 & 48 & 65 & 50 & 5 & 44 & 28 & 570 \\
\hline $\begin{array}{l}1 \\
2 \\
3 \\
4 \\
5\end{array}$ & $\begin{array}{l}\text { Mozambique } \\
\text { Afghanistan } \\
\text { Angola } \\
\text { Mali } \\
\text { Sierra Leone }\end{array}$ & $\begin{array}{l}106.5 \\
102.4 \\
106.8 \\
109.3 \\
110.0\end{array}$ & $\begin{array}{l}47 \\
32 \\
52 \\
59 \\
35\end{array}$ & $\begin{array}{l}78 \\
52 \\
84 \\
59 \\
62\end{array}$ & $\begin{array}{l}57 \\
70 \\
53 \\
44 \\
48\end{array}$ & $\begin{array}{l}4 \\
2^{x} \\
1^{x} \\
3 \\
4^{*}\end{array}$ & $\begin{array}{r}25 \\
3 \\
26 \\
31 \\
77\end{array}$ & $\begin{array}{c}28 \\
9^{*} \\
15 \\
27 \\
25\end{array}$ & $\begin{array}{c}300 \\
640^{*} \\
2000 \\
450\end{array}$ \\
\hline $\begin{array}{r}6 \\
7 \\
8 \\
9 \\
10\end{array}$ & $\begin{array}{l}\text { Malawi } \\
\text { Guinée-Bissau } \\
\text { Guinée } \\
\text { Burkina Faso } \\
\text { Niger }\end{array}$ & $\begin{array}{l}104.3 \\
107.3 \\
102.3 \\
106.4 \\
106.8\end{array}$ & $\begin{array}{l}48 \\
37 \\
32 \\
43\end{array}$ & $\begin{array}{l}82 \\
54 \\
45 \\
59 \\
55\end{array}$ & $\begin{array}{l}60 \\
33 \\
31 \\
50 \\
38\end{array}$ & $\begin{array}{l}7 \\
1^{x} \\
1 \\
1^{x}\end{array}$ & $\begin{array}{l}82 \\
44 \\
10 \\
76 \\
44\end{array}$ & $\begin{array}{l}45 \\
25 \\
30 \\
47\end{array}$ & $\begin{array}{l}170 \\
700^{x} \\
800^{*} \\
810 \\
700\end{array}$ \\
\hline $\begin{array}{l}11 \\
12 \\
13 \\
14 \\
15\end{array}$ & $\begin{array}{l}\text { Ethiopie } \\
\text { Tchad } \\
\text { Somalie } \\
\text { Mauritanie } \\
\text { Libéria } \\
\end{array}$ & $\begin{array}{l}106.8 \\
106.7 \\
109.1 \\
108.9 \\
105.7\end{array}$ & $\begin{array}{l}43 \\
33^{x} \\
45 \\
58\end{array}$ & $\begin{array}{l}64 \\
40 \\
50 \\
70 \\
56\end{array}$ & $\begin{array}{l}67 \\
20 \\
43 \\
.\end{array}$ & $\begin{array}{l}2 \\
j^{x} \\
i \\
6\end{array}$ & $\begin{array}{r}43 \\
42 \\
5 \\
40 \\
20 x\end{array}$ & $\begin{array}{l}14 \\
24^{x} \\
2 \\
20 \\
87\end{array}$ & $\begin{array}{c}960^{\circ} \\
1100 \\
\ldots \\
.\end{array}$ \\
\hline $\begin{array}{l}16 \\
17 \\
18 \\
19 \\
20\end{array}$ & $\begin{array}{l}\text { Rwanda } \\
\text { Cambodge } \\
\text { Burundi } \\
\text { Bhoutan } \\
\text { Népal }\end{array}$ & $\begin{array}{r}106.3 \\
106.3 \\
106.4 \\
96.0 \\
98.1\end{array}$ & $\begin{array}{l}58 \\
46 \\
66 \\
49 \\
34\end{array}$ & $\begin{array}{l}96 \\
74 \\
65 \\
51\end{array}$ & $\begin{array}{l}71 \\
44 \\
50 \\
29 \\
49\end{array}$ & $\begin{array}{l}10 \\
7 \\
7 \\
14\end{array}$ & $\begin{array}{l}87 \\
56 \\
63 \\
28\end{array}$ & $\begin{array}{l}22 \\
47^{*} \\
19 \\
7 \\
6\end{array}$ & $\begin{array}{c}210^{x} \\
500 \\
1310 \\
830\end{array}$ \\
\hline $\begin{array}{l}21 \\
22 \\
23 \\
24 \\
25\end{array}$ & $\begin{array}{l}\text { Yémen } \\
\text { Sénégal } \\
\text { Bangladesh } \\
\text { Madagascar } \\
\text { Soudan } \\
\end{array}$ & $\begin{array}{l}102.9 \\
104.3 \\
100.0 \\
105.7 \\
104.0\end{array}$ & $\begin{array}{l}45^{y} \\
48 \\
47 \\
83 \\
28\end{array}$ & $\begin{array}{l}30 \\
70 \\
84 \\
96 \\
71^{x}\end{array}$ & $\begin{array}{l}17 \\
53 \\
46 \\
83 \\
74\end{array}$ & $\begin{array}{r}\dot{5} \\
25 \\
\dot{9}\end{array}$ & $\begin{array}{r}8 \\
45 \\
74 \\
60 \\
14\end{array}$ & $\begin{array}{r}12 \\
41 \\
5 \\
62 \\
60\end{array}$ & $\begin{array}{l}600 \\
600 \\
570 \\
550\end{array}$ \\
\hline $\begin{array}{l}26 \\
27 \\
28 \\
29 \\
30\end{array}$ & $\begin{array}{l}\text { Tanzanie, Rép.-Unie de } \\
\text { Rép. centrafricaine } \\
\text { Namibie } \\
\text { Nigéria } \\
\text { Gabon }\end{array}$ & $\begin{array}{l}107.7 \\
110.6 \\
105.4 \\
106.0 \\
105.9\end{array}$ & $\begin{array}{l}95^{y} \\
48 \\
65 \\
66\end{array}$ & $\begin{array}{l}99 \\
61 \\
93\end{array}$ & $\begin{array}{l}60 \\
35 \\
64 \\
.\end{array}$ & $\begin{array}{l}1^{x} \\
\cdots \\
6 \\
6\end{array}$ & $\begin{array}{l}42 \\
87 \\
50 \\
58 \\
86\end{array}$ & $\begin{array}{l}60 \\
66 \\
40 x \\
80\end{array}$ & $\begin{array}{l}340^{x} \\
600 \\
370^{y} \\
800 \\
190\end{array}$ \\
\hline $\begin{array}{l}31 \\
32 \\
33 \\
34 \\
35 \\
\end{array}$ & $\begin{array}{l}\text { Ouganda } \\
\text { Bolivie } \\
\text { Pakistan } \\
\text { Rép.dém.pop.tao } \\
\text { Cameroun } \\
\end{array}$ & $\begin{array}{l}108.0 \\
109.6 \\
100.0 \\
106.3 \\
105.8 \\
\end{array}$ & $\begin{array}{l}56 \\
84 \\
45 \\
65 \\
\end{array}$ & $\begin{array}{l}83 \\
88 \\
55 \\
80 \\
86\end{array}$ & $\begin{array}{l}56 \\
88 \\
42 \\
96 \\
66 \\
\end{array}$ & $\begin{array}{r}5 \\
30 \\
8 \\
2^{x}\end{array}$ & $\begin{array}{l}31 \\
20 \\
87 \\
10 \\
63 \\
\end{array}$ & $\begin{array}{l}38 \\
42 \\
40 \\
10 \\
10\end{array}$ & $\begin{array}{l}300 \\
600 \\
500 \\
430 \\
\end{array}$ \\
\hline $\begin{array}{l}36 \\
37 \\
38\end{array}$ & $\begin{array}{l}\text { Bénin } \\
\text { Togo } \\
\text { Inde }\end{array}$ & $\begin{array}{l}108.9 \\
107.7 \\
100.0\end{array}$ & $\begin{array}{l}50 \\
55 \\
55\end{array}$ & $\begin{array}{l}52 \\
63 \\
73\end{array}$ & $\begin{array}{l}39 \\
33 \\
58\end{array}$ & $\begin{array}{r}9 \\
12 \\
34\end{array}$ & $\begin{array}{l}83 \\
81 \\
77\end{array}$ & $\begin{array}{l}45 \\
15^{*} \\
33\end{array}$ & $\begin{array}{l}160^{x} \\
420^{*} \\
460\end{array}$ \\
\hline & $\begin{array}{l}\text { Paye a tMMS éleve } \\
(71-140) \\
\text { Mediane }\end{array}$ & 106.3 & 75 & 94 & 86 & 33 & 48 & 50 & 200 \\
\hline $\begin{array}{l}39 \\
40 \\
41 \\
42 \\
43\end{array}$ & $\begin{array}{l}\text { Ghana } \\
\text { Côte d'Ivoire } \\
\text { Haiti } \\
\text { Zaïre } \\
\text { Lesotho } \\
\end{array}$ & $\begin{array}{l}107.5 \\
105.8 \\
105.6 \\
107.8 \\
117.0 \\
\end{array}$ & $\begin{array}{l}73 \\
60 \\
80 \\
73 \\
\end{array}$ & $\begin{array}{r}81 \\
71 \\
93 \\
76 \\
122 \\
\end{array}$ & $\begin{array}{r}61 \\
46 \\
85 \\
44 \\
150 \\
\end{array}$ & $\begin{array}{c}13 \\
3 \\
7 \\
1^{x} \\
5^{x} \\
\end{array}$ & $\begin{array}{l}33 \\
63 \\
23 \\
29 \\
\end{array}$ & $\begin{array}{l}55^{*} \\
20 \\
40 \\
40 \\
\end{array}$ & $\begin{array}{c}1000 \\
340^{\circ} \\
800^{\circ} \\
\ldots\end{array}$ \\
\hline $\begin{array}{l}44 \\
45 \\
46 \\
47 \\
48\end{array}$ & $\begin{array}{l}\text { Zambie } \\
\text { Pérou } \\
\text { Jamahiriya arabe libyenne } \\
\text { Maroc } \\
\text { Congo }\end{array}$ & $\begin{array}{l}105.7 \\
106.6 \\
106.7 \\
106.7 \\
109.8\end{array}$ & $\begin{array}{l}80 \\
86 \\
67 \\
62 \\
63\end{array}$ & $\begin{array}{l}90 \\
96 \\
66 \\
.\end{array}$ & $\begin{array}{l}90 \\
70 \\
38^{*}\end{array}$ & $\begin{array}{l}1^{x} \\
46 \\
36 \\
\cdots\end{array}$ & $\begin{array}{r}68 \\
9 \\
6 \\
64 \\
60\end{array}$ & $\begin{array}{l}39^{*} \\
78^{*} \\
76 \\
29^{*} \\
\cdots\end{array}$ & $\begin{array}{c}150 \\
300 \\
80^{x} \\
300^{x} \\
900^{*}\end{array}$ \\
\hline $\begin{array}{l}49 \\
50 \\
51 \\
52 \\
53\end{array}$ & $\begin{array}{l}\text { Kenya } \\
\text { Algérie } \\
\text { Indonésie } \\
\text { Guatemala } \\
\text { Arabie saoudite }\end{array}$ & $\begin{array}{l}106.9 \\
103.1 \\
105.0 \\
108.2 \\
104.8\end{array}$ & $\begin{array}{l}74 \\
66 \\
74 \\
75 \\
66\end{array}$ & $\begin{array}{l}96 \\
83 \\
97 \\
85 \\
83\end{array}$ & $\begin{array}{l}70 \\
87 \\
81 \\
90 \\
67\end{array}$ & $\begin{array}{l}27 \\
7^{x} \\
48 \\
23 \\
\end{array}$ & $\begin{array}{l}37 \\
27 \\
41 \\
48 \\
62\end{array}$ & $\begin{array}{l}28 \\
15 \\
49 \\
34 \\
88^{*}\end{array}$ & $\begin{array}{l}170^{x} \\
140^{x} \\
450 \\
200^{*}\end{array}$ \\
\hline $\begin{array}{l}54 \\
55 \\
56 \\
57 \\
58\end{array}$ & $\begin{array}{l}\text { Afrique du Sud } \\
\text { Myanmar } \\
\text { E! Salvador } \\
\text { Zimbabwe } \\
\text { Iraq }\end{array}$ & $\begin{array}{l}110.2 \\
105.0 \\
111.5 \\
105.2 \\
103.1\end{array}$ & $\begin{array}{l}81 \\
92 \\
81 \\
70\end{array}$ & $\begin{array}{r}94 \\
103 \\
97 \\
84\end{array}$ & $\begin{array}{r}92 \\
115 \\
86 \\
62\end{array}$ & $\begin{array}{r}48 \\
5 \\
47 \\
43 \\
.\end{array}$ & $\begin{array}{l}56 \\
12 \\
60 \\
67\end{array}$ & $\begin{array}{l}57 \\
50 \\
60 \\
50^{\circ}\end{array}$ & $\begin{array}{c}83^{x} \\
460 \\
\cdots \\
120\end{array}$ \\
\hline $\begin{array}{l}59 \\
60 \\
61 \\
62 \\
63\end{array}$ & $\begin{array}{l}\text { Egypte } \\
\text { Botswana } \\
\text { Turquie } \\
\text { Mongotie } \\
\text { Honduras }\end{array}$ & $\begin{array}{l}105.1 \\
110.5 \\
104.7 \\
104.9 \\
105.3\end{array}$ & $\begin{array}{l}54 \\
77 \\
79 \\
93\end{array}$ & $\begin{array}{r}79 \\
105 \\
93 \\
103 \\
104\end{array}$ & $\begin{array}{r}73 \\
116 \\
60 \\
109 \\
129\end{array}$ & $\begin{array}{l}38 \\
33 \\
77^{*} \\
35\end{array}$ & $\begin{array}{l}63 \\
62 \\
15 \\
51\end{array}$ & $\begin{array}{l}47 \\
78^{*} \\
77^{*} \\
99 \\
66\end{array}$ & $\begin{array}{l}320 \\
200^{*} \\
150 \\
140^{*} \\
220\end{array}$ \\
\hline
\end{tabular}

Note : Les pays sont énumérés par ordre décroissant de taux de mortalité des moins de 5 ans pour 1990 (voir tableau 1). 


\section{TABLE 8: BASIC INDICATORS ON LESS POPULOUS COUNTRIE}

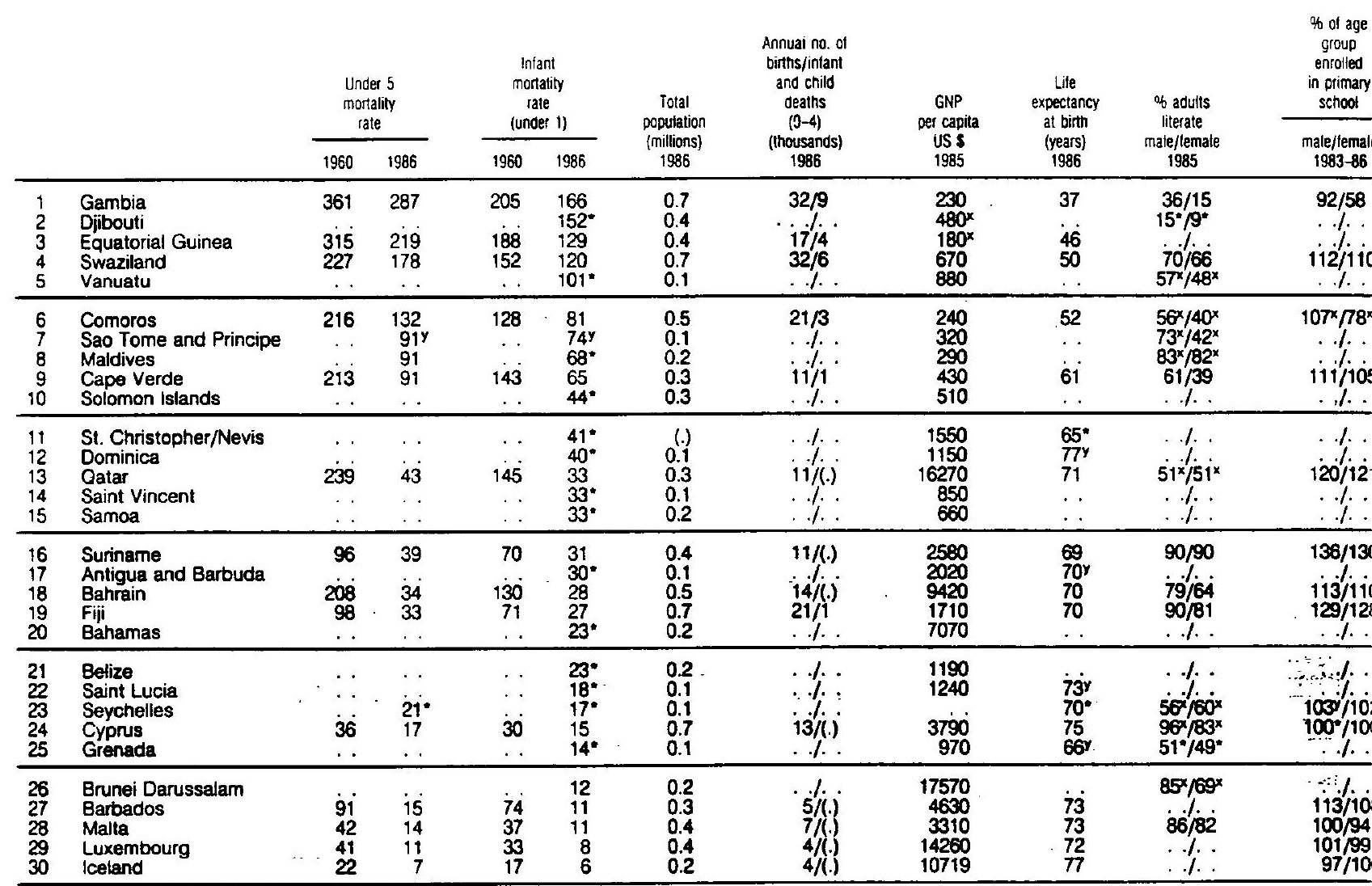

Note: nations are listed in descending order of their 1986 under-five mortality rates 
TABLEAU 8:

INDICATEURS DE BASE RELATIFS À DES PAYS MOINS PEUPLÉS

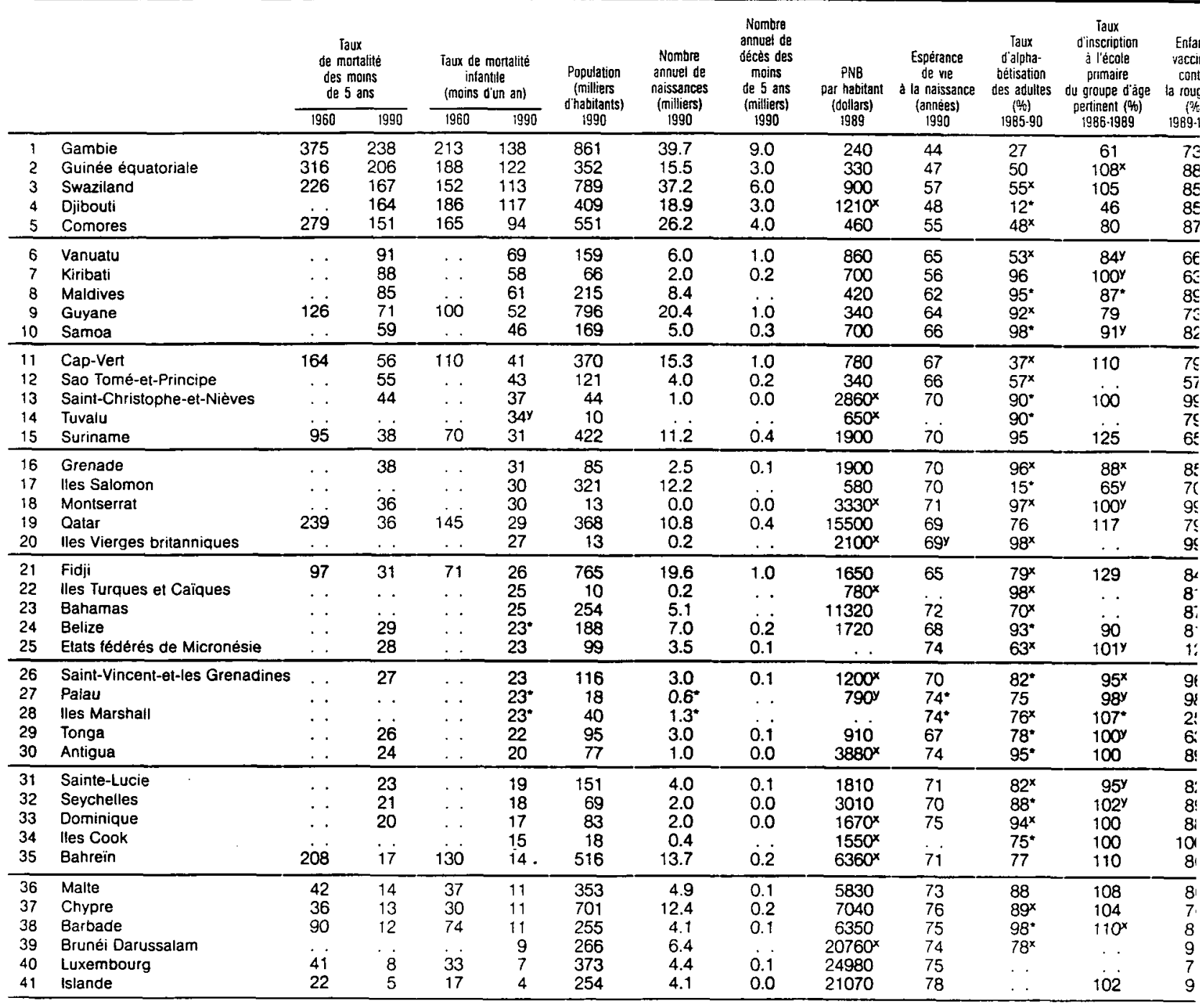

Note : Les pays sont énumérés par ordre décroissant de taux de mortalité infantile pour 1990 lorsque les taux de mortalité des moins de 5 ans ne sont pas dispon! 


\section{Definitions}

\author{
Under-five annual number of deaths of children \\ mortality under 5 years of age per 1,000 live \\ rate: burths
}

Infant annual number of deaths of infants under mortality one year of age per 1.000 live births rate:

GNP: gross national product. Annual GNPs per capita are expressed in current United States dollars. GNP per capita growth rates are annual average growth rates that have been computed by fitting trend lines to the logarithmic values of GNP per capita at constant market prices for each year of the time period.

Life the number of years new-born children expectancy would live if subject to the mortality risks

at birth: prevailing for the cross-section of population at the time of their birth.

Adult percentage of persons aged 15 and over literacy who can read and write.

rate:

\section{Primary and the gross enrolment ratio is the total secondary number of children enrolled in a enrolment schooling level - whether or not they \\ ratios: belong in the relevant age group for that level-expressed as a percentage of the total number of children in the relevant age group for that level. The net enrolment ratio is the total number of children enrolled in a schoolıng level who belong in the relevant age group. expressed as a percentage of the total number of children in that age group. \\ Income the percentage of private income \\ share: received by the highest $20 \%$ and lowest $40 \%$ of households.}

Low birth- 2.500 grammes or less. weight:

Breast- either wholly or partly breast-feeding feeding:

Child mild or moderate: between $60 \%$ and malnutrition: $80 \%$ of the desirable weight-for-age: Severe: less than $60 \%$ of the desirable weight-for-age

ORS: oral rehydration salts
Prevalence of the percentage of children with greater wasting than minus two standard deviations from

(acute the 50th percentile of the weight-for-

malnutrition): height reference population, i.e roughly less than $77 \%$ of the median weight-forheight of the United States National Center for Health Statistics reference population.

Access to percentage of the population that can health reach appropriate local health services by

services: the usual local means of transport in no more than one hour.

DPT: diphtheria, pertussis (whoopıng cough) and tetanus.

Maternal annual number of deaths of women from mortality pregnancy related causes per 100.000 rate: live births.

Children percentage of the children entering the completing first grade of primary school who primary successfully complete that level in due school: course.

Crude death annual number of deaths per 1.000 rate: population.

Crude birth annual number of births per 1.000 rate: population.

Total the number of children that would be fertitity rate: born per woman. if she were to live to the end of her child-bearing years and bear children at each age in accordance with prevailing age-specific fertility rates.

Absolute that income tevel below which a

poverty minimum nutritionally adequate diet plus

level: essential non-food requirements is not affordable.

Contraception percentage of married women age prevalence $15-44$ currently using contraception ratio:

ODA: official development assistance.

Debt service: the sum of interest payments and repayments of principle on external public and publicly guaranteed debts 


\section{Main Sources}

Under-five United Nations Population Division and and infant United Nations Statistical Office mortality:

Total United Nations Statistical population: Office and United Nations Population Division

Child United Nations Population Division population:

Births: United Nations Population Division

Infant and United Nations Population Division and child deaths: UNICEF

GNP per World Bank capita:

expectancy:

Life United Nations Population Division

Adult United Nations Educational, Scientific literacy: and Cultural Organization (UNESCO)

School Unted Nations Educational, Scientıfic enrolment and Cultura and Organization (UNESCO)

completion:

Household World Bank income:

Low birth- World Health Organization weight: (WHO)

Breast- World Health Organization

feeding: (WHO)

Child World Health Organization (WHO) and malnutrition: UNICEF Field Offices

Wasting World Health Organization (acute (WHO) malnutrition):

Food Food and Agriculture

production Organization of the United Nations (FAO)

and calorie and World Bank intake:
Access to World Health Organization drinking (WHO)

water:

Access to World Health Organization health (WHO)

services:

Immunization: World Health Organization (WHO) and UNICEF field offices

ORS: World Health Organization (WHO)

Births World Health Organization (WHO) attended:

Maternal World Health Organization (WHO) mortality:

Radio and United Nations Educational. Scientific television and Cultural Organization (UNESCO) receivers:

Crude death United Nations Population Division and birth

rates:

Fertility: United Nations Population Division

Urban United Nations Population Division population:

Contraceptive United Nations Fund for Population prevalence: Activities (UNFPA)

Inflation: World Bank

Absolute World Bank

poverty

level:

Expenditure World Bank

on health.

education

and defence:

Official Organisation for Economic

development Cooperation and assistance: Development (OECD)

Debt World Bank service: 


\section{APPENDIX $G$}

TABLES 
221

mppondi. $\times$ (i)

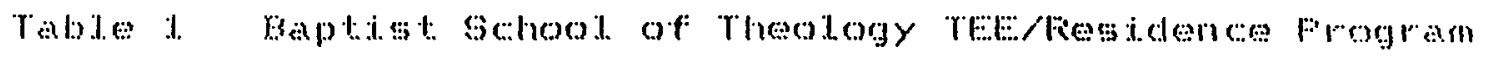

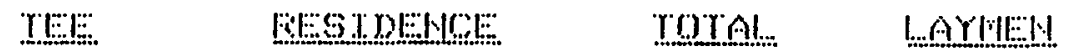

I...EVI:I... 1. 20

………...

20

1.6

( In complete (ovitury)

I. 1 VV: $1 \ldots$

24

……............

24

1. 8

Complotod

primary)

I.EVIEI.

1.2

1.8

30

2

(Secondary)

IEvi:1.. 4

12

24

36

26

$(T e r+i a r y)^{2}$

rabio

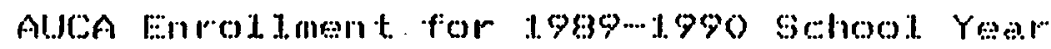

Buigious Af:idation

Adventi :st:

cationol. i. c:

Frotestant

Mlus:i i. i. in

() thes

roted Finmol I ment

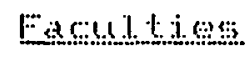

Mustingss; Ad An

Fincention

Theology

Teromology

Gci. incos

Frofess si onal.

Sperexint.

rotal Enmoldment.

$\begin{array}{rr}2083 & 64.6 \% \\ 71 & 2 \% .0 \% \\ 40 & 1.04 \% \\ 1 & 0.4 \% \\ 2 & 0.6 \%\end{array}$

323

156

(i)

46

34

23

1. I.

2

48 ก $5 \%$

1. $6.5 \%$

$1.4 .3 \%$

$10.5 \%$

7 "1.

$3.4 \%$

$0.6 \%$

32

"Hogarti, tos; 106. 
Details in Faculty of Sciences

Agriculture

Human Biology

Math-Physics

2

Public Health

7

Public Hoalth

Total Enrollment

$23^{1}$

Table 3 Second-tier Course Offerings

Title

Year: 1 Semester: 1

Credit

OT Survey-I,II

Daniel

Life and Teachings-1

Homiletics-1

Doctrines-1

Health

Spirit of Prophecy

Evangelism-Muslims

5

2

5

5

3

5

2

3

30

Semester: 2

OT Survey-III, IV

Revelation

Life and Teachings-II

Homiletics-II

Doctrines-I I

Church Manual

Music

Evangelism-Christian Family

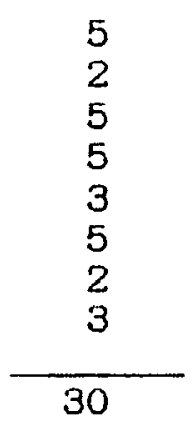

IAfrica-Indian Ocean Division of Seventh-day Adventists (Abidjan, Ivory Coast), Report of the Department of Education during the Year-end Committee, November 13-15, 1989, meeting of November 13, 1989 . 
Year: 2 Semester: 1

NT Survey-I, II

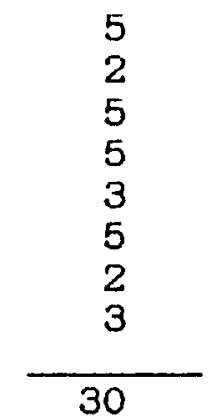

SDA Church History

Generig-I

Acts-I

Helping the Church to Grow

Letters to Church Leaders

Kinyarwanda

Evangelism-Following Jesus

2

30

Semester: 2

NT Survey-II, III

5

Church Organization/Adm

2

Generis-II

5

Acts-II

5

The Shepherd and His Work

3

Talking with God

5

French

2

Evangelism-Bringing People to Jesus 3 
APPENDIX H

TEE TRANSLATOR CONTRACT 
Evangel Publishing House

P. O. BOX 28963, NAIROBI, KENYA

\section{MEMO TO ALL TRANSLATORS OF TEE TEXTS'}

Evangel Publishing House is co-operating with the AEAM Theological Commission TEXT-AFRICA PROJECT to Publish a series of more than 40 texts to be used in Theological Education by Extension in Africa.

These texts are written in a special way and it is important that great care be taken in translating this material into other languages. Unless the translator is careful, much of what has been carefully prepared will be destroyed. Translating these texts is different from translating ordinary books.

More and more people are requesting permission to translate these texts. So far more than 134 people have requested permission to transiate these books into languages in Africa, Asia, Europe, U.S.A. and other parts of the world. This paper is prepared to help those engaging in translation work. The following points shoud be considered carefully before attempting translation work.

1. EVANGEL PUBLISHING HOUSE registered with the Kenya Government, holds the COPYRIGHT for all texts to be combined or published by AEAM- Text-Africa Project.

2. Evangel has agreed with TEXT-AFRICA to act as coordination agent in granting permission to translate or adapt these texts into other languages or versions. Because our combined resources are limited, we are anxious to avoid duplication of effort and confusion. Requests to translate or adapt must include the following in writing:-

(a) name and mailing address of mission, church, college or committee responsible.

(b) name of text(s) to be translated/adapted and language of each planned method of production (mimeograph, etc.) and initial quantity.

3. The following wording should replace "Published by Evangel" which appears in the English texts: "Translated into ........... (language name) ..... and produced by.............. (name of organization) ........ with the permission of Evangel Pubiishing House, Kenya" "Adapted for ..." should replace "Translated into...

(language name)....... when appropriate.

Evangel Publishing House will normally grant permission for no more than two texts to be translated or adapted at one time. We can grant further permission when a copy of the finished book is received. Permission to translate the se books does not include changing or altering the evangelical theological position, nor may particular denominational or theological stances be introduced (Such as Calvinism, Pentecostalism, Wesleyanism etc).

The TEE books which Evangel are publishing follow a method of intruction called programmed instruction. Programmed instruction is a method of teaching which helps students go through a carefully designed sequence of small steps to reach a specific objective. As the student goes through these small steps, he must interact with the material by answering carefully selected questions.

The TEE books have been carefully prepared. During the actual writing process, the lessons are tested with students. Then corrections made. Then the material is validated or tested in an actual class situation with about 50 students. The writers have learned much about their books by this continual testing. When the book is publishied in English, we know that it is a good book. We know that students will learn by using the book. BUT this means that the translator must be careful not to destroy what the writer has written.

In these texts, we are not trying to show how much we know or how good we know a language. We are trying to help people to do the work of God. A good translator is one who is able to take big thoughts and say them in simple words.

Some people who will use these books have little education. Therefore, use simple words, words that are well known and short sentences. In the English texts, we have used short sentences and simple words. You do the same. This will help people who are new readers.

The lessons are divided into small parts. We call these small parts "frame." The frames are divided from one another by a double-dotted line across the page. In each frame there is some teaching, a question and a place for the student to write an answer. You must follow the same plan in your transiation work. 
Never take teaching from one frame and put it into another frame. Do not try to combine the frames. If you do this, you will destroy the way the students will learn.

Be very careful when you translate the questions. Be sure to ask the same question as is asked in the English Text. These questions have been chosen very carefully.

The length of the line for the answer is important. Make sure the length of the line is the same length as the answer. The answer the student will write in the book, should just fill the line.

When you first read these progranmed books, it seems as if there is too much repetition. There is much repetition. But this is for a reason. If there is repetition in the English, then you should do the same: $::$ in your translation. Let us look at different ways we use repetition.

- There are key words or Ideas that the student must learn each day. These words or ideas must be translated the same way each time they appear. Do not translate them a different way each time they appear. We know that our students learn by saying or writing the same words many times. It is not enough for a student to read or write a word one time. He must do this many times.

Sometimes in English we have written an fdea in another way. This is to make the English text easier to understand. You may want to use a similar type of repetition in your vernacular transiation.

- Be very careful that the translation for a word in one lesson is the same translation used in a lesson later in the book. This is particularly true for review days. When you come to the review days, you can check your translation by looking at the last question for each day.

The last question for each day is put in the review lesson.

Usually, the answer to a question is NOT written in the same frame as the question. In fact, we try carefully not to put the answer in the same frame. In order to do this, we are very careful with the wording. This is especially true with the confirmation. Be careful in writing the answer to a previous question, that you do not write the answer to the question in that particular frame.

There are many fllustrations in these texts. But they are very important. The Illustrations are used to help the students learn well.

When there are drawings, you may adapt these to your local custons and culture, if necessary. For example, in the book Bringing People to Jesus there is a drawing of a pot with three legs. The people in some parts of Zambia use a pot with three legs. But when we translated this book for use in Kenya and Tanzania in Kiswahili, we did not use a pot with three legs. He used a pot sitting on three stones.This is what most people in Kenya use.

There are many kinds of verbal fllustrations in the book. These are:

(1) Biblical illustrations.

(2) True stories

(3) True-to-11fe stories.

(1) Biblical fllustratrations must be used in the same way as they are In the English text.

(2) True stories must be used as they are unless there is something objectionable in it about your local culture, or unless you can find a similar true story from your area. This is adviseable in fact, but be sure your story teaches the same thing that the story in the book teaches.

(3) True-to-life stories can be readily changed where necessary to fit your country. You may use local names. You do not have to use the same names as in the book. Perhaps there is an fllustration telling about otieno moving to Nairobi to get a job. If the book is being translated in Nigeria, the story might be about Odunaike going to Lagos to look for work.
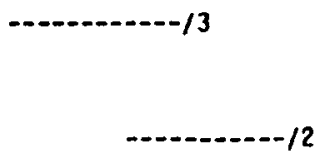
with

rou will notice that ${ }^{\text {the }}$ exception of the first book (Talking with God) we have JSED THE Revised Standard Version of the English BIble.

The vocabulary level in the Revised Standard Version is sometines very high and the eaders of these books in English have trouble. He sometimes put a smaller or impler word in bracts after the difficult word to help the English language eader. You should not translate the words we have added.

lowever, some translations of the Bible are hard for people to understand. There nay be hard words or uncommon words in your language which appear in your Bible. If this is the case, you may do what we have done. Where necessary, you can add 1 word or two to make the meaning clear.

In the Revised Standard Version, pronouns are not put in captals when they refer :o God. We do the same thing throughout our books. The words he, his, him and imself do not have capitals. If your translation of the Bible has capitals for :hese words, you may use capitals.

:ach new lesson should start on a new page as it does in the English.

In some countries, the Bible has not been translatedifor the people of all iribes. If you only have part of the Bible translated in your language, you may lave some problems when you come to verses in the books which are from the 0ld estament. In these cases it is important to carefully translate the English verses rom the Bible yourself.

lake your translation very easy to read. When the person reads what you have :ranslated, he should be able to think that it was written first in his own language. le should not see that the book is a translation.

These books talk to students. You should write your lessons in a conversational way. lo not talk down at the student. The students are mature adults. The writer of the rook is a friend of the student.

latch the order of the words. Make sure the translation says in your language :he samre meaning or ideas, that the English text gives. Do not just translate ords. Translate thoughts. T-ranslate ideas. Say the ideas the way you would ay them in your language.

hese texts are teaching people to do the work of God. The teachings are taken rom the Bible. These texts are carefully prepared to appeal to all the churches :hat belong to the Association of Evangelicals of Africa and Madagascar. The texts are repared carefully so there will be as little misunderstanding or controversy ibout doctrine as possible.

ranslators MUST NOT change the content of the teaching material without permission rom the publish-ers who work in co-operation with the TEXT project director of the IEAM Theological Commission. This is of importance for several reasons.

These materials have the name AEAM and therefore must reflect the teachings of AEAM members. Individual groups are not allowed to make changes that show the ir own particular teaching on a subject and be also permitted to use the AEAM name.

These lessons have been carefully written and tested. It may look easy to write this $k$ ind of material but in fact it is very difficult. Should you try to write new materials, it is possible for you to destroy the whole teaching sequence which has been so carefully prepared.

We feel that thesetexts are written to appeal to most churches. Should an individual wish to make special emphasis of a certain doctrine, this should be done during the weekly seminar meeting.

lbove all, remember that these lessons are prepared to help men and women do the cork of God. The teaching in these books is from the Bible. The work of ranslating a text is spiritual work. Before you begin your work, ask God for his ielp and guidance.

ijncerely.
至UEComson. - Editorial Department.
VANGEL PUBLISHING HOUSE.

.7 April 1985. 
APPENDIX I

ECONOMIC INDICATORS 
- 43 -

BVOLUTION DES TIIIX DE CIOISS/NCE POUR LES

IFDICATEURS ECONOHITUES SUR WW TERIODE 1980-1586.

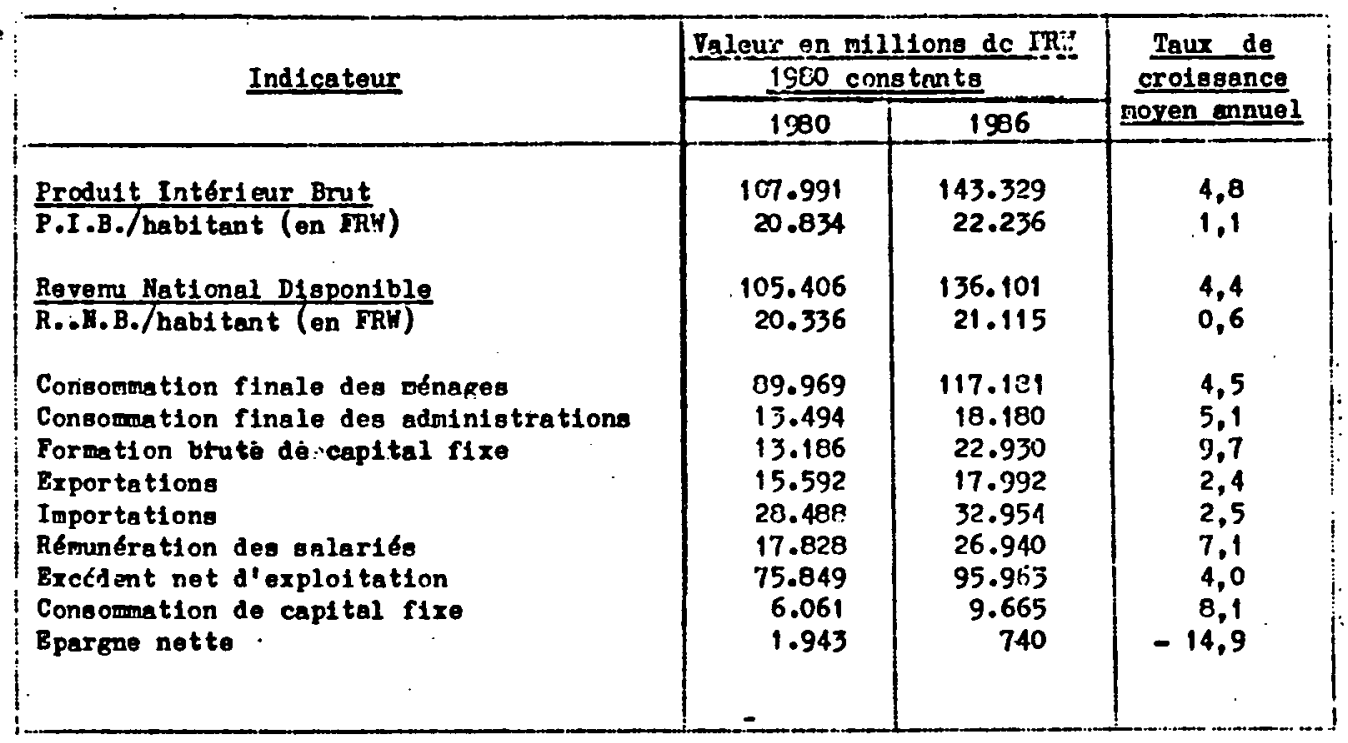

EVOLUTION DE LA PLRT RELATIVE DES SR'JiC.ES DINS LE P.I.B. DI: 1980.

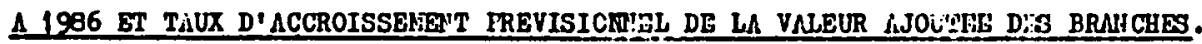

\begin{tabular}{|c|c|c|c|c|c|}
\hline \multirow[b]{2}{*}{ Brancho d'Activite } & \multicolumn{2}{|c|}{ Année 1980} & \multicolumn{2}{|c|}{ Année 1956} & \multirow{2}{*}{$\frac{\text { Taux de }}{\text { crolssance }}$} \\
\hline & \begin{tabular}{|l} 
V.A. de le \\
branche \\
\end{tabular} & $\frac{\text { Part do } 1 \mathrm{a}}{\text { branche }}$ & $\frac{\text { V.R. de la }}{\text { branche }}$ & $\begin{array}{l}\text { 3art de lo } \\
\text { byuphe }\end{array}$ & \\
\hline 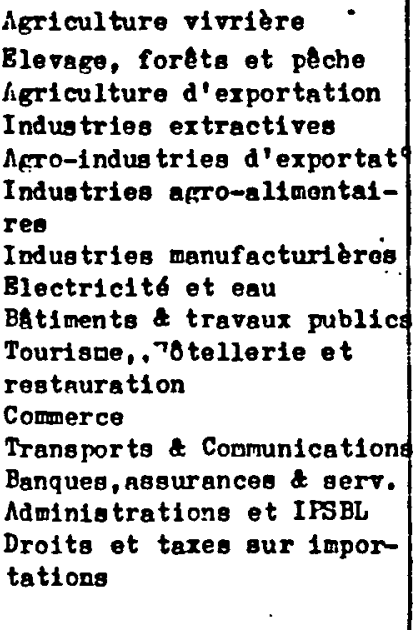 & $\begin{array}{r}38.923 \\
5.051 \\
5.532 \\
1.841 \\
999 \\
11.226 \\
4.257 \\
126 \\
4.818 \\
290 \\
15.595 \\
2.292 \\
4.113 \\
9.176 \\
3.752\end{array}$ & $\begin{array}{r}36,0 \\
4,7 \\
5,1 \\
1,7 \\
0,9 \\
10,4 \\
3,9 \\
3,1 \\
4,5 \\
0,3 \\
14,4 \\
2,1 \\
3,6 \\
3,6 \\
3,5\end{array}$ & $\begin{array}{r}46.290 \\
5.620 \\
6.231 \\
2.602 \\
1.935 \\
13.461 \\
6.270 \\
670 \\
7.480 \\
590 \\
\\
23.400 \\
3.130 \\
6.230 \\
13.950 \\
5.470\end{array}$ & $\begin{array}{r}32,3 \\
3,9 \\
4,3 \\
1,7 \\
1,1 \\
9,4 \\
4,1 \\
6,5 \\
5,2 \\
0,4 \\
16,3 \\
2,2 \\
4,4 \\
6,7 \\
3,0\end{array}$ & $\begin{array}{r}2,9 \\
1,8 \\
2,0 \\
5,9 \\
11,6 \\
3,1 \\
6,7 \\
32,1 \\
7,6 \\
12,6 \\
7,0 \\
5,3 \\
7,2 \\
7,1 \\
6,5\end{array}$ \\
\hline Produit Intérieur Erut & 107.991 & 100.0 & 143.329 & $10:, 0$ & 4,8 \\
\hline
\end{tabular}


RWANDA - GROSS NATIONAL PRODUCT (GNP)

$\begin{array}{lr}\text { GNP } 1987 \text { (millions) } & \$ 1,920 \\ \text { GNP } 1988 \text { (millions) } & \$ 2,064 \\ \text { GNP } 1989 \text { (millions) } & \$ 2,219 \\ \text { Annual GNP Growth } & 7.5 \% \\ \text { GNP per Capita } & \$ 292 \\ \text { \%GNP for Agriculture } & 37 \% \\ \text { \%GNP for Industry } & 23 \% \\ \text { \%GNP for Services } & 40 \% \\ \text { \%GNP for Defense } & 2.4 \%\end{array}$

Balance of Trade $\quad-\$ 69,000,000$ (1986)

RWANDA - GROSS NATIONAL PRODUCT (GNP)

$\begin{array}{lr}\text { GNP } 1989 \text { (millions) } & \$ 2,157 \\ \text { GNP } 1990 \text { (millions) } & \$ 2,194 \\ \text { GNP } 1991 \text { (millions) } & \$ 2,231 \\ \text { Annual GNP Growth } & 1.7 \% \\ \text { GNP per Capita } & \$ 282 \\ \text { FGNP for Agriculture } & 45 \% \\ \text { \&GNP for Industry } & 22 \% \\ \text { \&GNP for Services } & 33 \% \\ \text { \%GNP for Defense } & 1.6 \%\end{array}$

RWANDA - IMPORTS \& EXPORTS

Major Imports

Machinery

Vehicles

Electrical Products

Fuels

Lubricants

Foodstuffs

Beverages

Tobacco

Textiles

Clothing

Footwear

Building Materials

Major Exports Coffee

Tea

Cassiterite

Wolframite

Pyrethrum

Balance of Trade $\quad-\$ 125,000,000$ (1990)

Copyright 1992 PC Globe, Inc. Tempe, AZ, USA. All Rights Reserv 
RWANDA - NATURAL RESOURCES, AGRICULTURE, INDUSTRIES

Natural Resources

Agriculture

Major Industries
Cassiterite

Wolframite

Gold

Natural Gas

Hydroelectric Power

Fish

Plantains

Sweet Potatoes

Cassava

potatoes

Sorghum

Corn

Coffee

Tea

Tobacco

Pyrethrum

Cinchona

Bananas

Goats

Cattle

Sheep

Pork

Roundwood

Cement

Metal Products

Lye Soap

Sugar

Beer

Lemonade

Footwear

Cigarettes

Mining

Furniture

Plastics

Textiles 
RWANDA - MINING \& QUARRYING (1989)

$\begin{array}{ll}\text { Aluminum } & 0 \\ \text { Bauxite } & 0 \\ \text { Copper } & 0 \\ \text { Diamonds } & 0 \\ \text { Gold } & 0 \\ \text { Iron Ore } & 0 \\ \text { Lead } & 0 \\ \text { Magnesium } & 0 \\ \text { Phosphates } & 0 \\ \text { Salt } & 0 \\ \text { Silver } & 0 \\ \text { Tin } & 0 \\ \text { Uranium } & 0 \\ \text { Zinc } & 0\end{array}$

NOTE: A value of 0 indicates no production reported.

RWANDA - AGRICULTURE

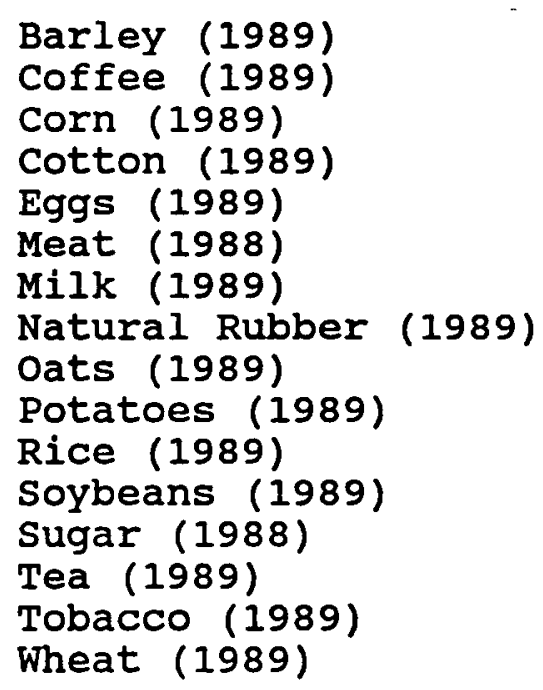

0

35,000 metric tons 89,000 metric tons 0

1,000 metric tons 27,000 metric tons 78,000 metric tons 0

184,000 metric tons 0

5,000 metric tons 4,000 metric tons 11,000 metric tons 3,000 metric tons 3,000 metric tons

NOTE: A value of 0 indicates no production reported. 


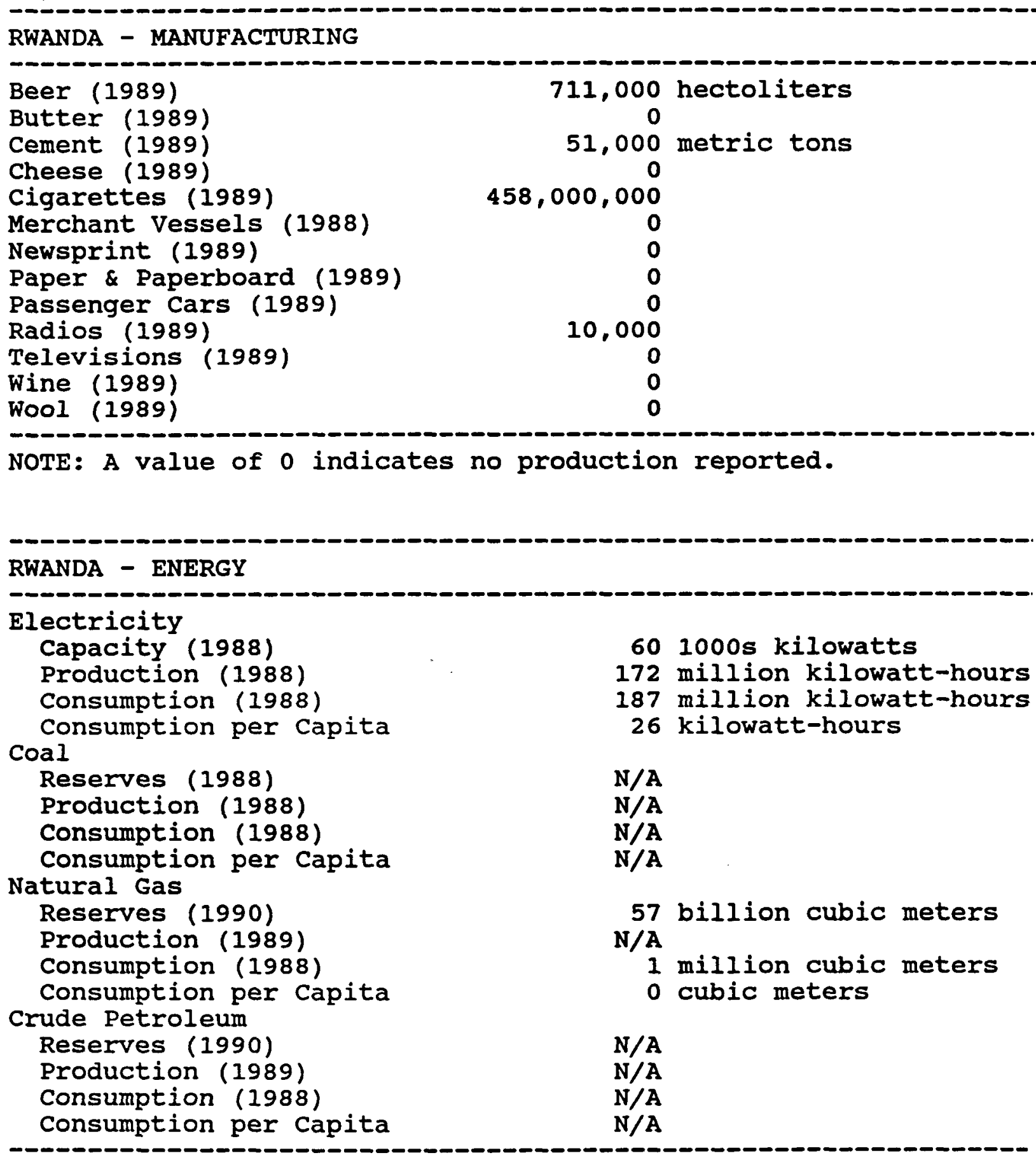




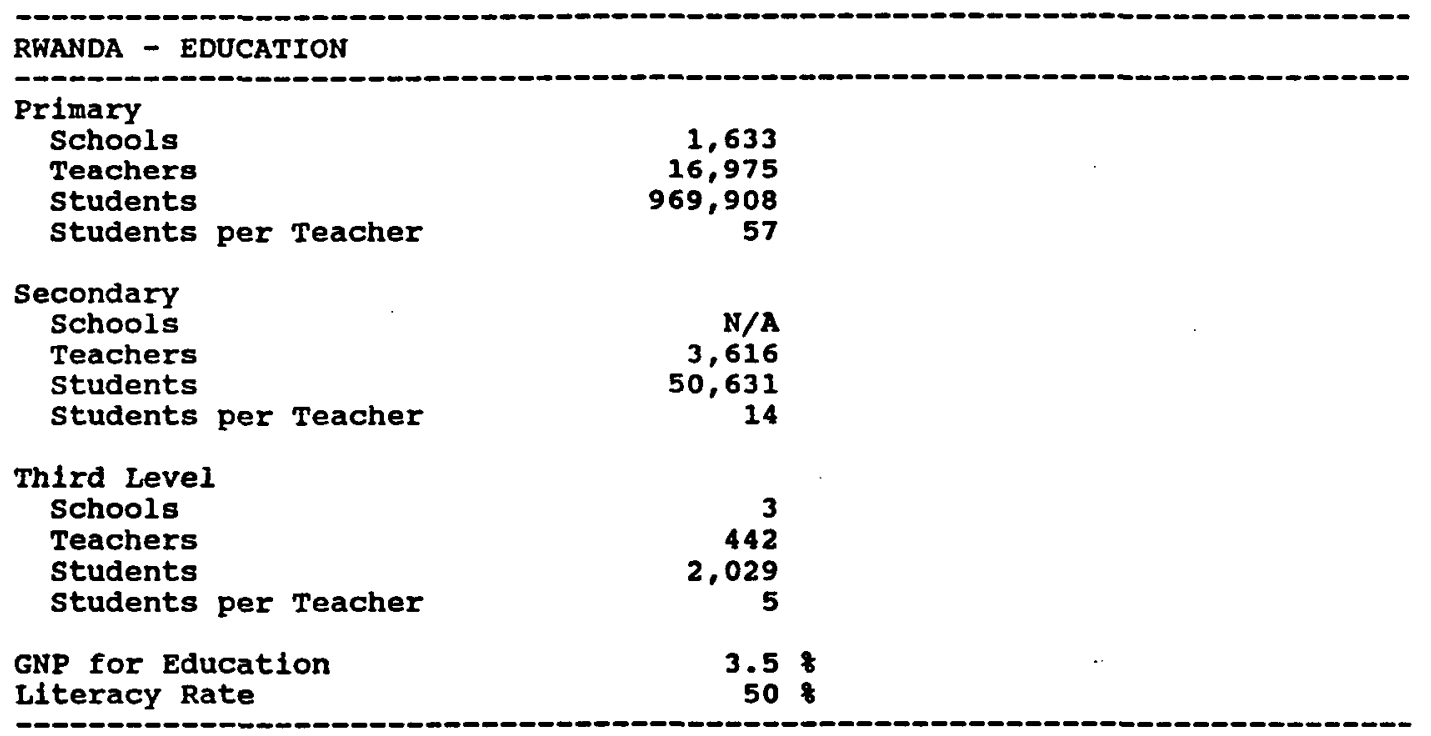

\section{RWANDA - CULTURE \& TOURISM}

- Official Languages: French and Rwanda.

- Visa: Required. Valid for stays up to 90 days.

- Health: Yellow fever vaccination required. Malaria suppressants, typhoid fever, pollo and hepatitis inoculations recommended. Cholera vaccination recommended for extensive travel. Large incidence of AIDS (acquired immune deficiency syndrome) in Kigali. Tapwater unsafe.

- Sights: Kagera National Park, Lake Kivu, Parc National des Volcans, Kigali, Virunga Mountains, Akanyaru River, wild gorilla sanctuaries.

- Climate: Cool and pleasant; rainy season from October to May. Washable clothing, sweaters or jacket during rainy season recommended.

- Currency: Rwanda franc (Feb. 1992: $124.94=$ = 1 US).

- Tourist Arrivals (1000s)

- Tourist Receipts (million \$) 9

- Telex Access Code (s)

- Ham Radio Prefix(es) 
APPENDIX J

SAMPLE TRAINING PROGRAM FORMATS 


\section{BCREDULE TOR LADIBS HBETIRGS}

Ap $\times 118$

6,00 P.A. SUPPER

7.00

DRYOTIOHAL -PAAtor Btaflord

AFRIL

7100 B.A. DREARTABT

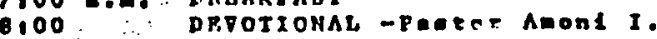

9100 RHOHINO CHRIBT - RUbY GteELOTd

10800 COOD IIRALTI AND HUTRITIOH PART 1- AL1CE RQCK

14.000

HOHB RBHBDIES - A1Le PeCk

12,00 . LUNCn

$1: 00$ P.A. HOLY SPIRIT - Ruby Btafford

2:00 BABBATI OBSBRVAICE - A11ce Peck

3100 QURGTIONB AHD AHBHBRB - Alice RUbY

4,00 . FAKILY WOREIIP - JaAe Bakex

5,00 SUPBER

6,00 GBT ACQUAHTBD

T100 $\therefore$ DEVOTIONAL - PAITOT ANORE RUBOIIYARge

B:00 BABBATH BCHOOL - ROAC Rugeligange

'ARRIL: 10

7,00 BRAREABT

BeCO $\because$ DEVOTIONAL $-P$. RYamiheto

9100

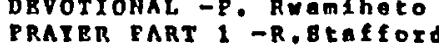

NUTRITIOH PART $2-A$. FACK

BIBLB BTUDI-P.StEEFOId

LUHCH

11200

12100

1,00

2,00

TAMILI

PAMILT PLALITINO CONT.

PRAYRR BART 2 -R. SteffOEd

HARRIAGB DOILA JorgenEEn

GUPPER

GET ACQUAINTED

DEVOTIOHAL - Pantor Seraje

QUBETION AND ANSHBRB

ARRIL 11

7100 BREAREABT

8,00 DEVOTIOH $-\mathrm{P}$. 80bihe

9100 PRATER FART 3 -RUBY

10,00 SPITITUAL HAR-RUBY

$11: 00$ NUTRITION P.3-A1LE

12.00 HUnch

$1,00 \mathrm{p}$ E COORIno-Ruby.A11ea.

2100 CoOKIHG Carolyn

1,00

$5: 00$

coorint

COORING

SUPPBR

GET ACQUAINTED

7,00 DBVOTIOHAI, -P. Reck

8,00 EVALUATION 
LAYHENS' IMSTIIUIE

Morch 21-April 1, 1990

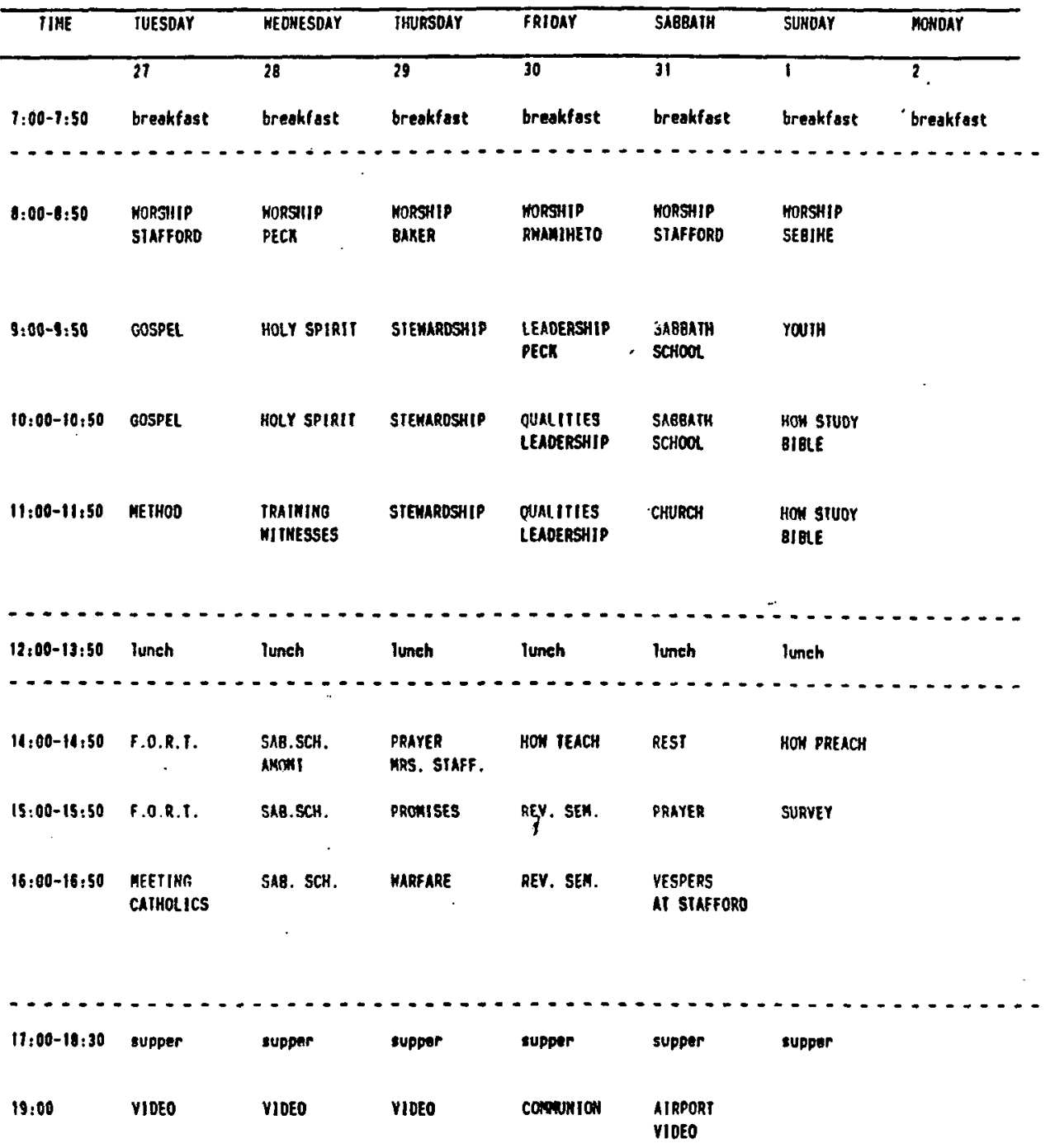




\begin{tabular}{|c|c|c|c|c|c|c|c|}
\hline \multicolumn{8}{|c|}{ rronuany 11-17 } \\
\hline Houn : : & OUMDAY 11 & Holnony 12 & TUESDAY/3 & WEUHR.SOAY & THURSDAY & FRIDAY 16 & SAR8กTH \\
\hline \multicolumn{8}{|l|}{ BREAKFAST } \\
\hline$\theta-9$ & . & Wonglite & HORSHIP & WORSH LP & Honsil P & honship & SАВBАTH \\
\hline $0-10$ & . & RVAIIOEL. & EVANOEL. & ciruncit & CIIURCn & chunch & scroor. \\
\hline $10-12 \cdots$ & & FERBOHALI & PUELIOI & ADHIMIST. & EI TURaY & I990es: & CHURCH \\
\hline $11-12$ & & BTATIORD & BIATIOND & FECK & STAFtond & $\begin{array}{l}\text { grocuss } \\
\text { Pluntiliumes }\end{array}$ & WORSIIP \\
\hline LUNCH : & & & $\therefore:$ & & & & \\
\hline $2-3$ & RBOIST- & $n$ & .1 & TnnININo & sng. scht. & SURVEY & REST \\
\hline $3-4:$ & RATION & $"$ & $: n$ & LAXMEN: & IYAMURRH. & & FAHET. \\
\hline 4-8:: & $\cdots$ & n. & $"$ & STAEIORD & SP.OE FR. & & $\begin{array}{l}\text { niscussil } \\
\text { Buin ge. }\end{array}$ \\
\hline \multicolumn{8}{|l|}{ SỤPEER } \\
\hline $7-8$ & & EILA & vroEo & EILM & VIDEO & EILM & VIDEO \\
\hline \multicolumn{8}{|c|}{ EEgRUARY 10-24 } \\
\hline houn .. & BUIDAX 18 & MONDAY /? & TUESDAY 20 & $\frac{\text { WEDHFSSAY }}{z i}$ & THURspnY & FกIDคY שב & SAв슬 \\
\hline \multicolumn{8}{|l|}{ ERenKIAST } \\
\hline 8-9 & HORSIIIP & Wonsule; ; & HORSHIP & WORSIIP & HOnSHIP & Wonshis & ВАВBАTII \\
\hline $9-10 \therefore$ & FRp:nch- & STEWARD- & RDUCATIOH & nesoLVIIIO & DOOTRIHRS & 198083 & ganoor \\
\hline $10-11$ & Ino: & SHIP: & MUERHANA & PROBLEMS I & STAEEORD & Discuss & CHURCll \\
\hline $11-12$ & STAETORD & BARBA & PUELISH. & STAETORD & $n$ & Plaleel: "Ry,t & WORSHIP \\
\hline \multicolumn{8}{|l|}{ LUHCH } \\
\hline $2-3$ & TEACHINO: & YouTu/ & CONSERVE & FRAYER: & $"$ & ЕХАм & REST \\
\hline $3 \div 4 i$ & STATYORD & TEMP. & MEMBEAS I & Hing. & $n$ & & FANEL DIS \\
\hline $1-6 \cdots$ & $n$ & SEB./ROH. & STAETOND & STAFEORD & $"$ & & VESEERS \\
\hline \multicolumn{8}{|l|}{ SUPQER } \\
\hline $7-8$ & vIDEO & Exth & VIDRO & VIDEO & VIDEO & COM.sEnv. & VISIT A.P \\
\hline
\end{tabular}




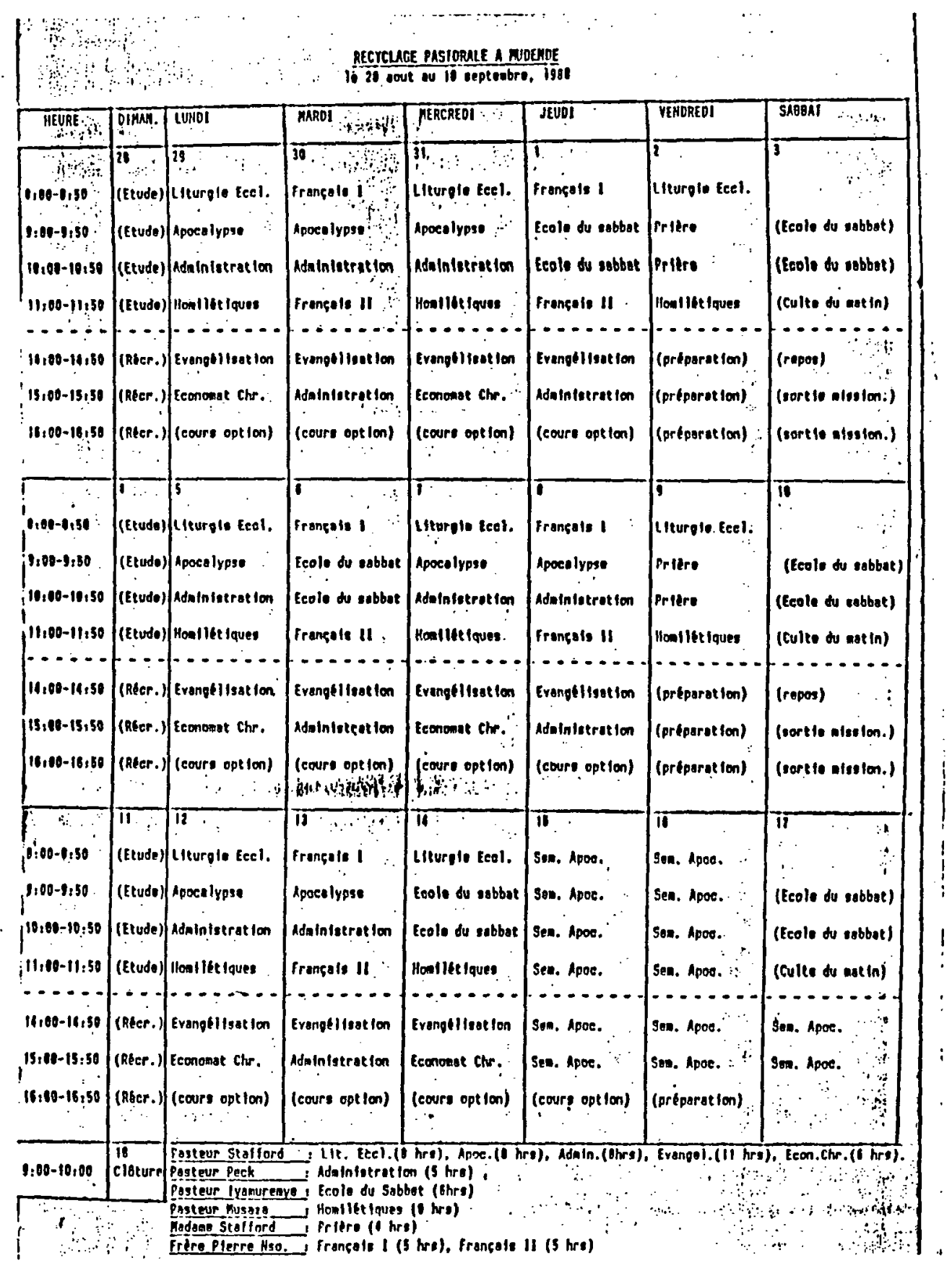




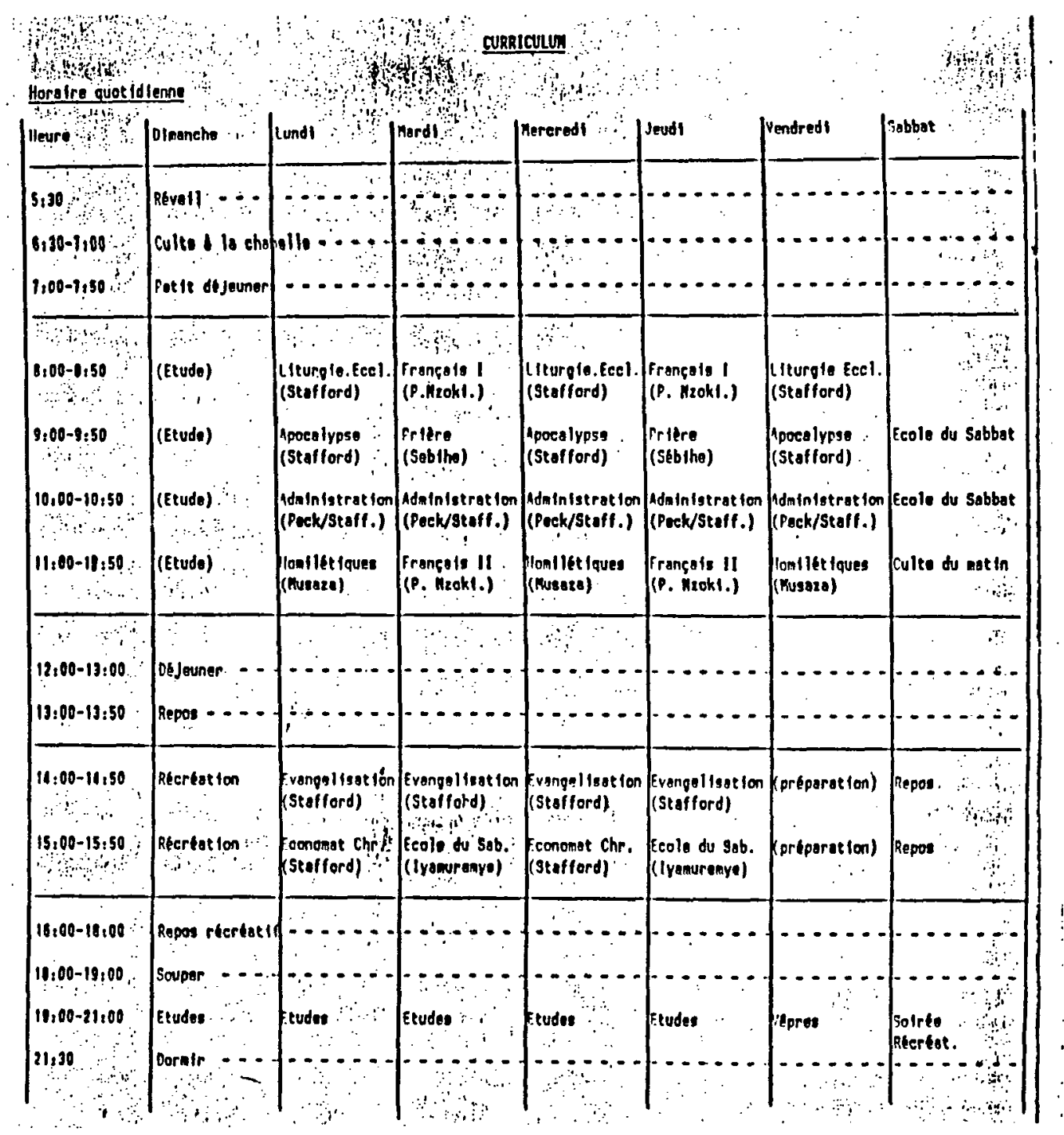




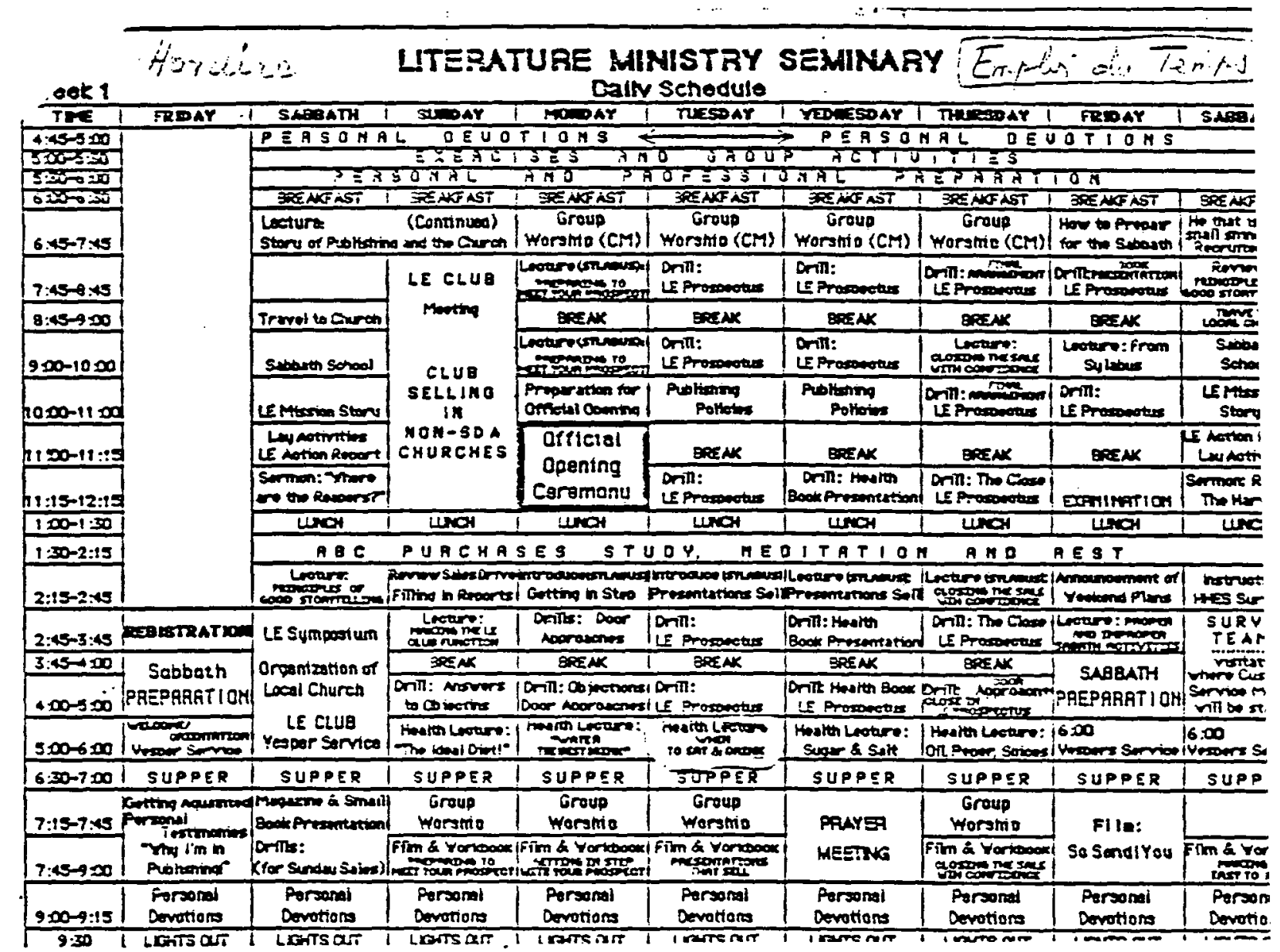


APPENDIX K

SALARY CATAGORIES

AID WAGE SCALE AND CONTINUING EDUCATION 


\section{Appendix $K$ \\ Salary Categories: \\ ATD WAOE SCALE AND CONTTHUTHO EDUCATTOY}

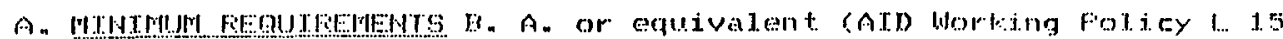
45)

a. 1. Jontify the various levels/categories of worters: Category 1, 2, or $B$ or A, B, 6 Level 1. 2, or 3 . Scade 1, 2, or 3

2. Define 1,2, 3

$$
\begin{aligned}
& \text { 1. :- Batom Secondary level. } \\
& \text { 2. :": Secondary love1 } \\
& \sigma=\text { College lovel }
\end{aligned}
$$

*3. Deternine percentage differentials

A. Ex. Level $1=50 \%$ of wage scale

tevel a $:=$ oo\% of wage scale

l..evel $3:=1.00 \%$ of wage gcal o

b. Establish percontage bractets at each loved up to their own 100 percentages.

4. Every arofer, irrespective of pregent. Lovel, is expected to airn $x$ Cous each year to qualify for maximun personal. wage percentage increment (subject to proper performance of the tob).

5. The Fitnistertal Association and the ATD Continuing Education

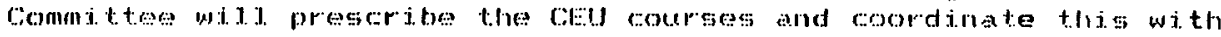
the Uni.on.

6. In owder to help workers on levels 1 and 2 to quatify themselves and be redy for level 3 , the continuing Fodution comettes will 


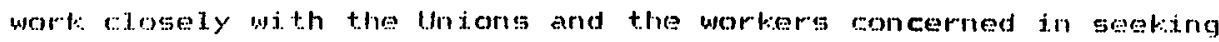
opportunites to upgrade themelselves.

The Continuing Fiducetion Committes may recommend one or more of the following options in hejping werkers to qualify themselves a

\section{Moving from Level 1 to level}

Level. 2 iss completion of secondary sctool education with university entrance gualjfication in the area of the worker.

a. Where possible the Mismion/conference/lonion and workers ghould share in the cost of eorrespondence courses gatred at preparing morbes to pass the high school poblic: exanination sucto as the GCE and GED.

f. Where corrempondence courges will not be practicable, workers in a given area should be brought togethar at specific: perjods and he givon organized coaching gearod lowards passing the high sohool public: examination such as Gol: (Cost should be shared as in "a").

… As: an alternative to the high school. public axanination such as the GCF. capable workers could be brought together at given poriods ofeh year and be coached for the (BED examinations. (Costs should be shared ass in "a".

d. Tn certain special cases where it is folt that a worligr has not an adequate level of general edecation to bonefit. from the (GCF, GED, Or similar public Examinations for the high setool.

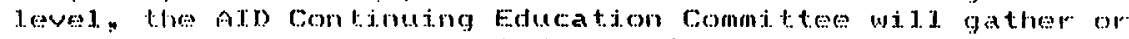

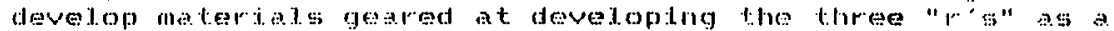
preliminary preperation to enable the worlore to benefit from the prografls outelined in ing by or c.

should there be a situation in which a worloer, astopites the romeliminary training, could not be found ready to pursue

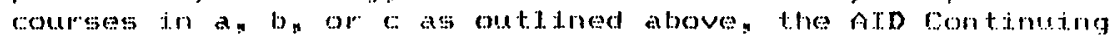

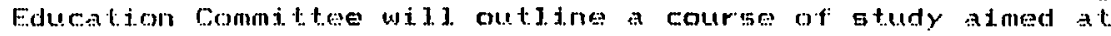
bringing tho worker to a high school luvel of pergonel. inted Jectual. at teanment.

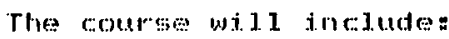


e. Ugarading wi thout education cualifications

The following list of factors. which is not part of the wagge scale, is to serve as a general gude to reap decisicons as uniform as; possible when consideration is given to uporading worloses from one category to another without the requisite educational. qualiftcations:

(1) The spiritual experience and maturity of the worker.

(2) Hig firuituluness as a soul winner.

(3) Hits grasp of the message and his stature as a bible student.

(4) His acquaintance with the writings of the spirit of Frophers and his acceptance of its teachings.

(5) His personal study hebits and the Iibrary he has bui.t. up.

(6) His personelity and ddsposition fnclucting progress made in overcorning weaknesses.

(7) The degree of his cooperation and willingness to receive rounge.1.

(8) Dilligence and faithfulness in the discharge of duties and willidigness to meset more than minimun requirsements.

(9) The manner in which he represents the gospes as well as the standard of his family and home.

(1.0) The trend and the tenor of his life including it te: influence on fellow worthersing and church membersis

(11) The weight and nature of responsibility borne and the success achieved in i.t.

(12) Frogress toware the standard of eclucation required at that bar, it betng recognixed that ohile sterling character is a prime essential, it does not of itself replace educational. gua 1.tifications.

\section{Moving from Love1 2 to level 3}

Ievel $I$ is; the A. A. or equivalent degreo qualification required by ArD larking Folicy for fuld entrance into ministery.

a. Workers with the required university entrance qualification 
should be encouraged to attrend one of the ministerial training ingtitutions in the ivision in order to benefit fully from the educational programs provided by those institutions. (The litssicm/Conference/tnion should share in a bursary or financial program).

b. Whereg beceuse of circumstences beyond their control, wortersconnot attond the mtnisterial training full-1-time, they should be granted periodic leave of abmence to enable them to attend sumer and vaction sessiong organized by our ministerial trafning institutions.

c.. Where preferred, worters should be encouraged to qualify themselves for entry into l..evel. 3 through colloge level. correspondence courses provided by aceredited bodies such as Home STudy Tnstitute, Columbia Union College, Atlantic Wnton College, etc.

The Continuing Eituration Committeo will nogotiate wi.th in body such as Hone Study Institute in order to bring the courses within reach of our unorers as reliates to cost, distance, etc.

\section{TMEOLEMEHATIOH}

1. ATDCOM votes Guidelinesia

2. Union Committers vote Guidelines

3. Unjon Committeses vote idst of workers

4. ArDCom vote polioy change

* Example on Item

love1 3 Col1009

Ordained $(\$ 67-\$ 100)=67 \%-100 \%$

Level 2 econdary

Ordained $(\$ 40.20-\$ 60)=67 \%-100 \%$

Level 1 Heimary

Ordained $(\$ 33 n 50-\$ 50)=67 \%-100 \%$ 
APPENDIX L

PROGRAMMED LEARNING LESSON SAMPLES 
WEEK 1: THE MINISTRY OF HEALING

DAY 5: HOW DOES THE SIN OF THE FIRST PEOPLE AFFECT US?

1. Are you enjoying these lessons? Let us see if you remember what you are learning. Do not look back at yesterday's lesson.

What is the original cause of death, disharmony, and ill health?

2. We have seen that the original cause of ill health was the disobedience of the first people. We have seen that God allowed Adam and Eve to feel the result of their sin. Some people say, "But that happened so long ago. What has the sin of the first people got to do with us? How does their punishment affect us?"

Have you ever had such questions in your mind?

3. Today we shall try to answer these questions. At the end of the lesson you will be able to explain:

We inherited from the first people the desire to sin.

Their punishment still affects us in many ways.

(1) We have pain in childbirth.

(2) We have to work hard.

(3) We must die.

Take your Bible now and read Genesis 3:16-24. Were Adam and Eve allowed to remain as happy people in the garden of Eden?

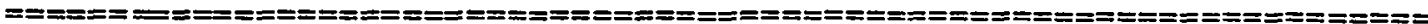

4. Adam and Eve were now sinful people. They could not stay in the garden of Eden. They had a desire to sin which they would pass on to their children. We are glad that there are only a few diseases which one can inherit. This means that the parents suffer from a certain disease. Then their child is born with the same disease. We say the child has inherited this disease from his parents.

Is there anyone in your family who has inherited a disease? 
5. This is what happened with the sin of the first people. The desire to sin has been inherited by the rest of the human race. All people are born with the desire to please themselves rather than God. The Bible has much to say about this.

Job 14:4:

Nothing clean can ever come from anything as unclean as man.

What have you inherited from the first people?

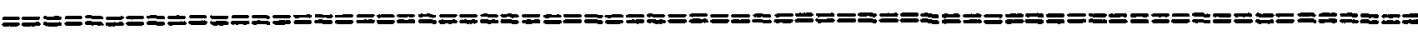

6. It is terrible to think about this. But we have all inherited the desire to sin. Let us look at some more verses from the Bible which show this, using the Good News translation.

Romans 6:12:

Sin must no longer rule in your mortal bodies, so that you obey the desires of your natural self.

1 John 3:4:

Whoever sins is guilty of breaking God's laws, because sin is a breaking of the law.

According to these verses, what does our desire to sin cause us to break?

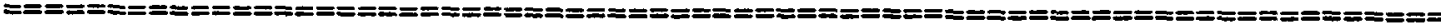

7. It causes us to break God's laws. This is what the first people did. They sinned, and when they sinned, this changed their nature. They were no longer clean before God--they were sinful. When we are born, we are born with this desire to sin. The desire to sin itself is sin.

Romans 5:12, 19:

Sin came into the world through one man. ...

all people were made sinners as the result of the disobedience of one man.

From whom did we inherit our desire to sin?

8. We inherited it from the first people. Yesterday we saw that their disobedience brought death and ill health into the world. This still affects us today in many ways.

(1) We have pain in childbirth.

(2) We have to work hard.

(3) We must die.

What did we inherit from the first people? 
9. We inherited the desire to sin from the first people. Let us now see how their punishment still affects us. We shall find that we still feel its results. When we work in the maternity department, we see much suffering from childbearing. This reminds us of the women's punishment which God gave.

Genesis 3:16:

And he said to the woman, "I will increase your trouble in pregnancy and your pain in giving birth.

With whom did God cause pain in childbearing to begin?

10. It began with Eve, the first woman. But it came because she disobeyed God. God had to punish her. We still feel the results of this punishment today.

What is the first way in which the punishment still affects us?

(1)

(2) We have to work hard.

(3) We must die.

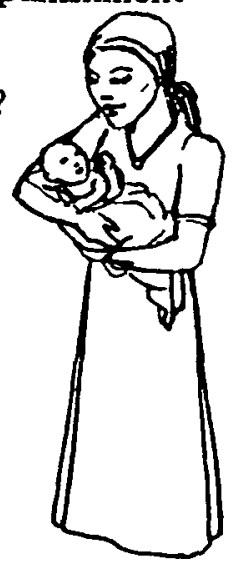

We mim die.

11. We still feel the effects of Adam and Eve's punishment very much. We have pain in childbirth. And we have to work hard. The ground is still under a curse. At first there were no weeds or harmful insects. There were no droughts or floods or germs or poisonous plants. The wild animals were not harmful.

What effects of the curse on the ground do we see today?

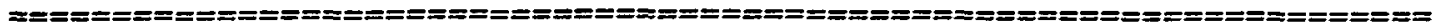


12. You may have written that we have weeds, harmful insects, droughts and floods. You may have shown that we fight germs, poisonous plants, and wild animals. Or you may have written other effects which can be discussed in class. In the garden of Eden there were none of these things. Many foods grew by themselves. Adam enjoyed taking care of them. But after the curse he had to work very hard.

What is the second way in which the punishment of the first people still affects us?

(1) We have pain in childbirth.

(2)

(3) We must die.

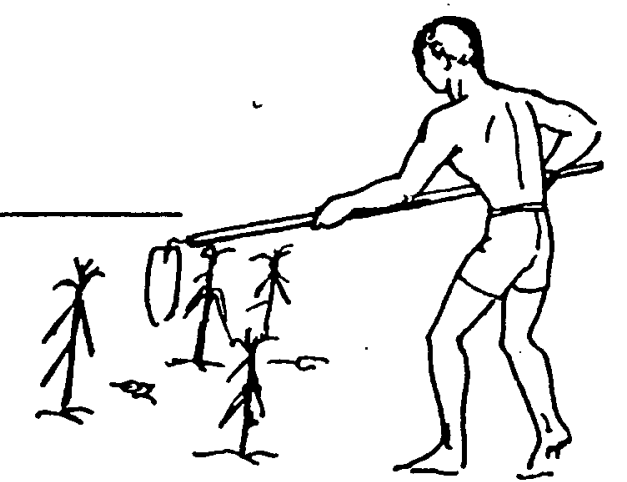

13. We know how hard people have to work today. They have to hoe their lands. They have to plough and reap. Even after all the hard work there may not be enough rain. Or sometimes the insects spoil the harvest.

So we see that we have not only inherited the desire to sin from the first people. But their punishment still affects us very much.

Romans 5:12:

Sin came into the world through one man, and his sin brought death with it. As a result death has spread to the whole human race because everyone has sinned.

Which result of Adam's sin is spoken about in this verse?

14. This verse talks about death. We have looked at many results of the first people's sin. We found that these still affect us. Of all the results we perhaps feel this last one most. We all expect to die some day. We nurse many people who die. Some of our relatives have died already.

Because of the sin of the first people; we have pain in childbirth, we have to work hard, and we must die. But what did we inherit from the first people? 
15. We inherited the desire to sin. We were born with the evil desire to please ourselves. This brings a sad end.

James 1:14-15:

But a person is tempted when he is drawn away and trapped by

his own evil desire: Then his evil desire conceives and gives birth

to sin; and sin, when it is full-grown, gives birth to death.

What is the third way in which the punishment of the first people still affects us?

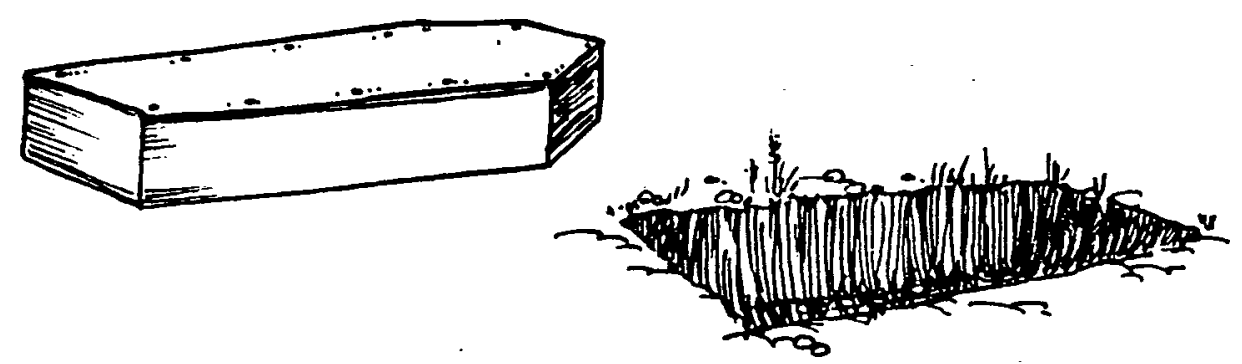

(1) We have pain in childbearing.

(2) We must work hard.

(3)

16. We must die. Think about this. People have different ideas about how death came into the world. Perhaps you know a story from the older people about how death came.

In that story, did God send death as a punishment?

17. Be ready to talk about this in the discussion meeting.

What did we inherit from the first people?

Write three ways in which their punishment still affects us.

(1)

(2)

(3) 
WEEK 2: PREPARING FOR THE COMING OF THE HOLY SPIRIT DAY 2: THE PROMISE OF POWER

Acts 1:8:

1. This week we are learning how the disciples prepared. They prepared to receive understanding and power.

What did Jesus say the disciples should do to get understanding and power for witnessing?

In what way is Jesus with us now?

2. Jesus said they should wait for the Holy Spirit. Jesus is with us now through the Holy Spirit.

Last week we learned that Acts 1:8 is an important verse. It tells us what Acts is about. It is also a wonderful promise which Jesus gave as he left the earth. Today we will memorise this verse.

Acts 1:8: But you shall receive power when the Holy Spirit has come upon you; and you shall be my witnesses in Jerusalem and in all Judea and Samaria and to the end of the earth.

Find Acts 1:8 in your Bible and read it. To whom was Jesus speaking when he gave this promise?

3. He was speaking to his disciples. His chosen disciples were sometimes called apostles. This is how Luke spoke of them when he wrote the book of Acts.

Acts 1:2:

he was taken up, after he had given commandment through the Holy Spirit to the apostles whom he had chosen.

Jesus was speaking to the apostles. But we know that he was also speaking to us. He told them first to witness in Jerusalem. Jerusalem was the place where the disciples were. They should witness everywhere, but they should start where they were. Jerusalem is like the town or village where you live.

Write the name of the town or village where you should begin witnessing. 
4. You should have written the name of your home town or village. But Jesus said we should not only witness at home. He said the disciples should go out from Jerusalem to Judea and Samaria. In the same way, we should not witness in our own town only. We should take the good news through all our country. This is the part which is under our government. Judea and Samaria are like our country.

You should begin witnessing around your home, but you should go on. Write the name of the next place you should witness.

5. You should have written the name of a country like Nigeria, Zambia, or Kenya. The disciples were to witness in Judea and Samaria. But the Jews hated the people of Samaria. They are like people we do not like. Perhaps you remember what happened to the prophet Jonan. He refused to go to Nineveh and preach. He did not want to go to people who were his enemies. Jesus said we should witness to people we do not like. He said the Holy Spirit will give us power to witness to them.

Look into your own heart now. Try to be honest. Are there some people you would not like to witness to?

Perhaps as you thought about this, you had to write Yes. Will you pray about this?

6. We should witness at home and in our country. The Holy Spirit also sends us to the end of the earth. This means the rest of the world outside our country. It is not enough to witness to our own people. Remember the words of Jesus.

Matthew 28:19:

Go therefore and make disciples of all nations.

Do you think it is possible for you yourself to witness outside your country? 
7. Perhaps you do not see any way to go out now. But God wants some to go to the ends of the earth. Some day he may open the way for you to go. Or he may let you help to send another witness. Acts 1:8 gives God's plan for a growing witness.

\section{Acts 1:8:}

But you shall receive power when the Holy Spirit has come upon you; and you shall be my witnesses in Jerusalem and in all Judea and Samaria and to the end of the earth.

Take time to memorise this verse now. Read it three times. Try to say it without looking at it. Read it again. When you can say it, write it here.

8. This is God's plan for his church to grow. Christians should witness everywhere. We should start where we are. We have someone to give us power.

\begin{tabular}{|c|c|c|c|c|}
\hline \multicolumn{5}{|c|}{ Acts $1: 8$} \\
\hline $\begin{array}{l}\text { The } \\
\text { early } \longrightarrow \\
\text { church }\end{array}$ & $\begin{array}{l}\text { had } \\
\text { power to } \longrightarrow \\
\text { witness }\end{array}$ & $\underset{\text { Jerusalem } \longrightarrow}{\longrightarrow}$ & $\begin{array}{l}\text { in Judea } \\
\text { and } \\
\text { Samaria }\end{array}$ & $\begin{array}{l}\text { to the } \\
\text { end of } \\
\text { the earth }\end{array}$ \\
\hline $\begin{array}{l}\text { The } \\
\text { church } \\
\text { today }\end{array}$ & $\begin{array}{l}\text { has } \\
\text { powrer to- } \\
\text { witness }\end{array}$ & $\begin{array}{l}\text { in our } \\
\text { home } \\
\text { town }\end{array}$ & $\begin{array}{l}\text { in } \\
\text { our } \\
\text { country }\end{array}$ & $\begin{array}{l}\text { to the } \\
\text { end of } \\
\text { the earth }\end{array}$ \\
\hline
\end{tabular}

From Acts 1:8, who gives power to witness?

9. The Holy Spirit gives power. There are many different ways for Christians to witness at home. They can live true Christian lives. They can speak to their friends about Christ. They can give Christian papers and books to people.

Write one way you have witnessed where you live. 
10. Be ready to tell your answer in class. We can also witness where we live through the church. The church has many ways to witness for Christ. It witnesses by preaching. It witnesses by teaching the Bible. It witnesses by helping people in the name of Jesus. You can witness at home by helping your church to witness. You can preach or teach. You can give money to help your church witness. You can pray for the work of your church.

Write one way you witness through the church where you are.

11. We also want to obey Jesus and witness in our country. You can witness when you take journeys in your country. Your church can send you to preach. It can send evangelists to preach in other parts. It can send missionaries to live in other parts of your country. Your church can help radio programmes that speak all over the country.

Write one way you and your church are witnessing in other parts of your country.

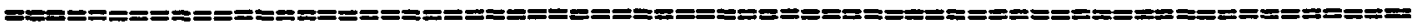

12. We will hear your answer in class. Jesus also said to witness in other countries of the world. This can be done through missionaries or evangelists. Radio programs can be sent to other countries. Groups can prepare Bibles in different languages.

Perhaps you think you do not have to do this. Your church may be very small. But Jesus said he would give us power to do it. Your church can work together with other churches. Together you can witness in other countries.

Does your church help anyone witness outside your country?

What wonderful promise did Jesus give us as he left the earth? Answer by saying Acts $1: 8$ to yourself.

$==$

13. Some Christians do not know how to witness. Some churches do nothing about this work. They do not know how to witness in their own country or other countries. They have not been taught to tell others the good news. Some pastors do not think much about this. They are not troubled about lost people. But Jesus told us to go and witness. We must obey his command.

Will you try to teach your church to witness in their town, their country, and other countries? 
14. We will talk about this together.

What wonderful promise did Jesus give us as he left the earth? Answer by writing Acts 1:8:

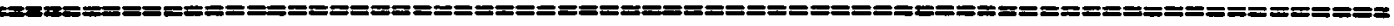


B I BL I OGRAPHY 


\section{BIBLIOGRAPHY}

Africa-Indian Ocean Division (Abidjan, Ivory Coast). Minutes of Year-end Division Meetings, November 13-15, 1989. Meeting of November 15, 1989.

Africa-Indian Ocean Division of Seventh-day Adventists (Abidjan, Ivory Coast). Report of the Department of Education during the Year-end Committee, November 13-15, 1989. Meeting of November 13, 1989 .

Africa-Indian Ocean Division of Seventh-day Adventists Working Policy. Accra, Ghana: Advent Press, 1988 .

Andrews University Seminary Faculty Reaffirmation, "The Seminary and the Church: A statement to the Constituency." Berrien, springs, MI, 1981.

Arn, Win, and Charles Arn. The Master's Plan. Pasadena, CA: Church Growth Press, 1982.

Atkinson, Harley. "Theological Education by Extension: An Alternative in Education," Christian Education Journal $10(1990): 2: 33$.

Ayres, Francis 0 . The Ministry of the Laity.

Philadelphia, PA: Westminster Press, 1962.

Barrett, David B. "Annual Statistical Table on Global Mission: 1992." International Bulletin of Missionary Research, January 1992, 27.

. "Rwanda." World Christian Encyclopedia. 1982. 588 .

- Schism and Renewal in Africa. London, England: Oxford University Press, 1986.

Bresee, Floyd. "Annual Council Report." Ministry, December 1989, 21.

Britannica Book of the Year, 1989 ed. S.v. "Rwanda." 
Bruce, Alexander Balmain. The Training of the Twelve. Grand Rapids, MI: Zondervan Publishing House, 1963.

Church, J. E. Quest for the Highest. Exeter, England: Paternoster Press, 1981.

Congo Union Mission Minutes. Fizi, Congo. September 27, 1957 .

Crider, Donald William. "Development and Rationale of Theological Education by Extension of the Free Methodist Church in South Africa." M.A. Thesis, Fuller Theological seminary, 1980.

Delhove, Lydie M. A Daughter Remembers D. E. Delhove. Canon City, Co: Master Printers, 1984.

Follett, Phil. Survey of Pastors at Workers' Meeting, Kigali, Rwanda, 1988.

General Conference of Seventh-day Adventists, 127 th Annual Statistical Report 1989. Silver Spring, MD: General Conference of SDA, 1989.

Gerber, Virgil, ed. Discipling Through Theological Education by Extension. Chicago, IL: Moody Press, 1980.

Gitwe College notes provided by former Director of Gitwe, Aaron Nzahumunyurwa. Dated July 12, 1988.

Grant, James P. La Situation Des Enfants Dans Le Monde 1992. Geneva, Switzerland: Tex SA, 1991. - The state of the World's Children 1988. New York: Oxford University Press, 1988.

Groves, C.P. The Planting of Christianity in Africa. 4 vols. London, England: Letterworth Press, 1964.

Hellberg, Carl J. Missions on a Colonial Frontier. Sweden: Belringska Boktryckeriet Lund, 1965.

Hiebert, Paul G. Anthropological Insights for Missionaries. Grand Rapids, MI: Baker Book House, 1985.

Hoffman, Paul E., ed. Theological Education in Today's Africa. Geneva, Switzerland: Lutheran World Federation, 1969. 
Hogarth, Jonathan, Kiranga Gatimu, and David Barrett. Theological Education in context. Nairobi, Kenya: Uzima Press, 1987.

Holland, Fred. Teaching Through T.E.E. Nairobi, Kenya: Evangel Publishing House, 1975.

Kinsler, F. Ross. The Extension Movement in Theological Education. Pasadena, CA: William Carey Library, 1981 .

"Extension: An Alternative Model for Theological Education." In Learning in Context, 28, 35. England: New Life Press, 1973. - Ministry by the People. Geneva, Switzerland: wCC Publications, 1983. - "Open Theological Education," Theological Education, 1974 . - "Theological Education by Extension: Service or Subversion?" Missiology 6 (1978): 196.

Kissinger, Warren S., ed. Brethren Life and Thought. Oak Brook, IL: Bethany Theological Seminary, $1984,2: 105$.

Lamb, David. The Africans. New York: Random House, 1985 .

Linden, Ian. Church and Revolution in Rwanda. New York: Manchester University Press, 1977.

Long, Albert M. "Christianity in Rwanda with Special Emphasis on the Seventh-day Adventist Church." M.A. thesis, Andrews University, 1973.

Mackinnon, Ronald P. "A Program of Theological Education by Extension and Lay Preacher's Institutes for the Christian and Missionary Alliance Church (and Mission) of the Philippines," M.A. thesis, Fuller Theological seminary, 1975.

Maquet, J. J. The Premise of Inequality in Ruanda. London, England: Oxford University Press, 1961.

- "The Problem of Tutsi Domination." In Cultures and Societies of Africa, edited by simon ottenberg and Rhobe Ottenberg. New York: Random House, 1960. 
Masih, Rehmat. "Theological Education in Pakistan: A Case Study of the Gujranwala Theological Seminary," M.A. thesis, Fuller Theological Seminary, 1974 .

Mbiti, John S. Introduction to African Religion. London, England: Whitstable Litho, 1981.

McGavran, Donald. The Church in a Revolutionary Age. St. Louis, MO: Christian Board of Publication, 1955 .

McKinney, Lois. "Why Renewal Is Needed in Theological Education." Evangelical Missions Quarterly 18 $(1982): 86$.

Medley, Carlos. "Newsbreak." Adventist Review, October $30,1986,8$.

. "New Strategy for Africa." Adventist

Review, October 30, 1986, 13.

- "Wilson Calls Church to Adopt Global

strategy." Adventist Review, October 30, 1986, 8 .

Monsieur, S. E, ed. Rwanda, Land of Eternal Spring. Boulogne, France: Editions Delroisse, 1973.

Muganda, Baraka G. "Planning A Needs-Assessment-Based Approach to Continuing Education Programs for Seventh-day Adventist Clergy in the East Africa Division." Ed.D. dissertation, Andrews University, 1983.

Mugemana, Manasse. "Evangelistic Methods Used by Adventists in Rwanda." Unpublished rough draft of SDA Church History in Rwanda, 1989. Property of author.

Mulholland, Kenneth B. Adventures in Training the Ministry. Nutley, NJ: Presbyterian and Reformed Publishing, 1976.

Neighbor, Ralph W., Jr. Where Do we Go from Here? Houston, TX: Touch Publications, 1990.

Nelson, Dwight. Quoted in a sermon preached at the Pioneer Memorial Church, Berrien Springs, MI. September $30,1989$. 
Newfeld, Don F. "Rwanda." Seventh-day Adventist Enclyclopedia.

Newman, J. David. "Global Strategy Shifts Church's Goal." Ministry, June 1989, 18.

Njoroge, R. J., and G. A. Bennaars. Philosophy and Education in Africa. Nairobi, Kenya: General Printers, 1990 .

Nyrop, Richard F, Lyle E. Brenneman, Roy V. Hibbs, Charlene A. James, Susan Macknight, and Gordon $C$. McDonald, Area Handbook for Rwanda. Washington, D.C.: U.S. Government Printing Office, 1985.

Oosterwal, Gottfried. Patterns of SDA Church Growth in America. Berrien Springs, MI: Andrews University Press, 1976.

Patterson, George. obedience-oriented Education. Alta Loma, CA: Community Baptist Church, n.d. - Church Planting through obedience oriented Teaching. Pasadena, CA: William Carey Library, 1981.

P. C. Globe. P. C. Globe, Inc., Tempe, Arizona, 1992.

Perlez, Jane. "Rwanda Pledges Democratization." The New York Times International, 15 November 1990, A5.

Pierson, R. G., Rector of AUCA, to author, December 13, 1991.

Rasi, Humberto $M_{.}$, and Charles R. Taylor. "Adventist Global Strategy." Dialoque, Vol. 1, No. 2, 1989, 5 .

Republique Rwandaise Ministere Du Plan. 2eme Table Ronde Des O.N.G. Kigali, Rwanda: n.p. 1985.

Rossman, Vern. "The Breaking in of the Future: The Problem of Indigenization and Cultural Synthesis." International Review of Mission, 52 (1963): 130 .

"Rwanda Accepts Cease-Fire Plan." The New York Times International. 19 October 1990.

Rwanda Union Mission. Secretary's statistical ReportQuarterly, 4th quarter, 1990. 
Schaller, Lyle E. Growing Plans. Nashville, TN: Abingdon Press, 1983.

Seaton, Ronald S., and Edith B. Seaton. Here's How: Health Education by Extension. Pasadena, CA: William Carey Library, 1976.

"The Schools of the Prophets." True Education, vol. 4, no. 18 (1927): no. 2

Seventh-day Adventist Yearbook. Hagerstown, MD: Review and Herald Publishing Association, 1989.

Simmonds, John W., Jr. "How the Banyarwanda Understand Man." Practical Anthropology 10 (1963): 17, 18.

Sprunger, W. Frederic. TEE in Japan. Pasadena, CA: William Carey Library, 1981.

The Undergraduate Colleges 1989-1990 Bulletin. Berrien Springs, MI: Andrews University, 1989.

"Thousands Invade, Rwanda Reports." The New York Times International. 3 October 1990.

Turner, Edward R. "Pastoral Care as A Factor of Church Growth." In Servants for Christ: The Adventist Church Facing the '80s. Ed. Robert E. Firth. Berrien Springs, MI: Andrews University Press, 1980 .

Twagirayesu, Michel, and Jan van Butselaar, eds. Ce don que nous avons recu. Kigali, Rwanda: Eglise Presbyterienne au Rwanda, 1982.

Universite Adventiste d'Afrique Centrale Bulletin. Annuaire De L'Annee Academique. Mudende, Rwanda: Universite Adventiste, 1988-1989.

Waliggo, J. M., and others. Inculturation: Its Meaning and Urgency. Nairobi, Kenya: st. Paul Publications, 1986.

Ward, Daniel. "Theological Education by Extension: A Proposal for India's Free Methodist Church." M.A. thesis, Fuller Theological Seminary, 1982 .

Ward, T., and S. Rowen. "The Significance of the Extension Seminary." Evangelical Missions Quarterly (1972), 9:25-26. 
Ward, Ted, and Margaret Ward. Programmed Instruction for Theological Education by Extension. Lansing, MI: Michigan State University, 1970.

Warren, Max. To Apply the Gospel. Grand Rapids, MI: William B. Eerdmans Publishing Company, 1971.

Waugh, Geoffrey. "Liberate Leadership: An Innovative Model of Theological Education by Extension Using Seminar Cassettes," M.A. thesis, Fuller Theological Seminary, 1984 .

Weld, Wayne c. The World Directory of Theological Education by Extension. Pasadena, CA: William Carey Library, 1973.

Wendell, Burton, retired missionary, to author, June 6 , 1988 .

White, Ellen G. The Acts of the Apostles. Mountain View, CA: Pacific Press Publishing Association, 1958 .

- The Desire of Ages. Mountain View, CA: Pacific Press Publishing Association, 1940. - Christ's object Lessons. Washington, D.C.: Review and Herald Publishing Association, 1941. - Education. Mountain View, CA: Pacific Press Publishing Association, 1942.

- Fundamentals of Christian Education. Nashville, TN: Southern Publishing Association, 1923.

- Patriarchs and Prophets. Mountain View, CA: Pacific Press Publishing Association, 1952 .

- Prophets and Kings. Mountain View, $C A$ : Pacific Press Publishing Association, 1960. - Testimonies for the Church. 9 vols. Mountain View, CA: Pacific Press Publishing Association, 1948.

- The Ministry of Healing. Mountain View, CA: Pacific Press Publishing Association, 1942 .

Winter, Ralph D, ed. An Extension Seminary Manual. Pasadena, CA: William Carey Library, 1969. 
Woodberry, J. Dudley, ed. Muslims and Christians on the Emmaus Road. Pasadena, CA: Zwemer Institute of Muslim Studies, 1989. 
VITA

Robert G. Peck

Academic Achievements:

Degree
Bachelor of Arts in Religion
Master of Divinity
Doctor of Ministry
Churches Pastored:

Institution $\quad$ Year

Union College $\quad 1971$

Andrews University 1973

Andrews University 1992

Church

Location

Years

Grand Junction (Intern)

Colorado

1973-1975

Rifle/Glenwood Springs

Colorado

1975-1977

Texas

North Houston/Conroe

Missouri

1977-1978

1978

\section{Administrative Posts:}

Position

Location

Years

Conference secretary

Missouri

$1978-1980$

Conference Secretary

Iowa-Missouri

1980-1983

Union President

Rwanda

1983-1990

Union President

Sahel

1990-

\section{Other Work Experience:}

Position

Location

Years

Telephone Company Utilityman

Telephone Company Lineman

Colorado

1959-1960

Colorado

1961-1963

Telephone Co. Cable Splicer

Colorado

1963-1966

Family:

Event

Marriage: To Alice M. Clayton

Birth: Clayton scott Peck

Birth: Carrie Marie Peck
Location

California

Colorado

Colorado
Year

1962

1962

1965 
Ordination: Robert G. Peck Marriage: Carrie/Jim Bordenaro Graduation: Clay/Selene Birth: Alyssa Bordenaro Birth: Landon Peck Graduation: Clay Graduation: Jim Graduation: Carrie Ordination: Clayton S. Peck Birth: Brianna Bordenaro
Colorado

1977

Iowa 1982

Iowa

Union College

1982

Nebraska

1985

1987

Iowa

1988

Andrews University Univ. of Nebraska

Nebraska Nursing

1988

Iowa

Nebraska
1989

1991

1991

1992 